\title{
Westminster Regained: \\ The Applicability of the Westminster System for \\ Executive Power in India, Ceylon and New Zealand after Independence
}

By

Harshan Kumarasingham

\begin{abstract}
A thesis submitted
to the Victoria University of Wellington

in fulfilment of the requirements for the degree of

Doctor of Philosophy in Political Science
\end{abstract}

Victoria University of Wellington

2008 


\section{Abstract}

This thesis investigates the applicability of the Westminster system for the sovereign executives of India, Ceylon and New Zealand. These three countries became independent in the late 1940s and though individually having different contexts share constitutional and institutional resemblances, thanks to their Westminster legacy, that allows a valuable and original triangular study. The thesis analyses the crucial first decade of independence to assess the events, decisions and political environment of these New Westminsters and how the local executives adapted and reacted to the Westminster system in this constitutionally nascent era. This thesis will examine and compare the three case studies from a common theoretical approach. Firstly, each country's cultural background and conditions will be analysed to comprehend not only the context in which Westminster functions, but also more importantly to understand the exercise of power available within the localised social and political arena. The cultural conditions are crucial since they impact directly on the constitutional and political exercise of Westminster executive power and give an invaluable insight into how the ambiguous and flexible tenets of Westminster were interpreted in local contexts. Secondly, the concept of horizontal accountability and delegative democracy will be tested in the New Westminsters to see how well the purported checks and balances of the Westminster model operate on the executive level in the crucial nation building era. Prime Ministers are unquestionably important, but how well the Cabinet and the Governor-General (or constitutional President) operate as actors of accountability and how well all three actors conform to the Westminster cultural and institutional expectations of their office is also highly relevant. The actions and inactions of these executive actors of this early era are fundamental to the future functions and expectations of their offices. Finally, there will be an event or issue selected during this decade, which has path dependent resonance, since it would in future become critical to the operation or complexion of the country. Often this event or issue had not yet been fully appreciated, but had been allowed to develop through the employment of Westminster flexibility and power demonstrating the importance of this critical juncture period. The adaptable Westminster system was an essential element in the political development of these countries. 


\section{Acknowledgments}

Throughout the long and often exasperating path to complete my $\mathrm{PhD}$ there have been many people that have greatly assisted to make completion possible. Academics, officials, librarians, friends and family have all contributed to this all absorbing project. The academics at Victoria University of Wellington's School of History, Philosophy, Political Science and International Relations, especially Professor Sekhar Bandyopadhyay, Professor Stephen Levine, Professor Margaret Clark, Dr Pat Moloney and Dr Rod Alley have all given me the benefit of their notable academic (and life) experience. The Director of the Centre for Strategic Studies, Commander Peter Cozens (ret'd), has also been most generous in his intellectual and social support.

I would also like to acknowledge in gratitude the scholarships and grants that I have been fortunate to receive and without which much of my research, especially overseas, would not have been possible. Specifically I mention the New Zealand ViceChancellors Committee (Claude McCarthy Scholarship), Education New Zealand (New Zealand Postgraduate Study Abroad Award), the Ministry of Foreign Affairs and Trade (two MFAT Historical Research Grants) and the Faculty of Humanities and Social Sciences at VUW for their PhD research grants.

The kind and patient librarians at the Institute of Commonwealth Studies in London; the staff at the manuscript section of the Nehru Memorial Museum and Library in New Delhi; the archivists and librarians at the National Archives and Alexander Turnbull Library (manuscript section) in Wellington; as well as the library staff at VUW's library have all been invaluable in accessing the information required for this project.

At a more direct level I would like to thank Miss Gemma Freeman for her editing labours, Pro-Chancellor Ian McKinnon for his many efforts on my behalf, Professor Elizabeth McLeay for her guidance and research assistance, Professor Nigel Roberts who had oversight of the thesis, Dr Margaret Hayward for her constant support, intelligence and humour and above all to Dr Paul Brooker for being such an excellent and diligent supervisor, who more often than not would go beyond what is expected of doctoral supervisors. 
Without my family and friends I could not have achieved anything since they have generously given me so many opportunities and support.

This thesis is dedicated to my dear parents Dr Bala and Mrs Renuka Kumarasingham. 


\section{Contents}

Abstract

Acknowledgements

iii

Contents

$v$

Chapter One: Introduction and Theory

$\underline{\text { India } 1947-1957}$

The New Raj-A Tryst with Westminster?

Chapter Two: Mixed Messages?: Indian Responses to its British Legacy

Chapter Three: The Indian Version of First Among Equals

Chapter Four: Federalism: A Paramount Mechanism

Ceylon $1948-1958$

\section{Ceylonese Surprises behind a Westminster Facade}

Chapter Five: "British is Best" - An Elite Faith 105

Chapter Six: Executive Affairs - The Ceylonese Partnership of Convenience

Chapter Seven: Communalism: A ‘Canker’ Ignored?

\section{New Zealand 1947-1957}

\section{Westminster "Reforged"}

Chapter Eight: Westminster Beyond the Seas?

Chapter Nine: The Executive Purity of the "Wellington Model" 


\section{Conclusion}

Chapter Eleven: New Westminsters Compared

Appendix

Governors-General, Presidents and Prime Ministers of India, Ceylon and New Zealand of the Post-Independence Decade

Bibliography 


\section{Introduction and Theory}

In June 1953 Elizabeth II was crowned Queen at Westminster Abbey as monarchs had done for over nine hundred years. However, this crowning was made unique by the fact that the young Queen would be the first monarch to have the demonstrative title "Head of the Commonwealth" solemnly proclaimed soon after becoming Sovereign, which had been given to her by consent and not by hereditary succession. ${ }^{1}$ The Commonwealth was now actively part of the ancient ceremony, from having the Queen vow to serve it to having the emblems of the Commonwealth nations embroidered into her coronation gown. Crucially, the very evidence of the connection was made visible by the prominent appearance of Commonwealth Prime Ministers taking a leading role in the ceremony; among others were Sir Winston Churchill, Robert Menzies of Australia, Sidney Holland of New Zealand; and Jawaharlal Nehru of India and Dudley Senanayake of Ceylon. These men of varied lands and views represented the common constitutional heritage of their countries - they represented at Westminster their own Westminsters. The Palace of Westminster became globalised and refounded beyond the British Isles, adapting and accommodating to the conditions of foreign lands.

The Queen's coronation marked the inexorable fusion of Empire to Commonwealth. The Indian subcontinent had gained independence and the Dominions became increasingly self-determining in their political and constitutional actions. Events like the decision of India to become a Republic and remain in the Commonwealth in 1949 and the passing of The Royal Titles Act 1953 formalised the evolution and constitutional divisibility of Commonwealth countries - and thus their legal separation and separate direction from Britain. Despite such relentless change and rapid dissolution of Empire the British Westminster model of parliamentary democracy was transplanted and implanted across the globe: the speaker's wig and mace remained at Parliament House even though at Government House the Union Jack was folded away. The Westminster system and model became one of Britain's most famous and enduring

\footnotetext{
${ }^{1}$ Vernon Bogdanor, The Monarchy and the Constitution, Oxford: Oxford University Press, 1997, p 263 and Nehru as the leader of the only republic member of the Commonwealth at the time welcomed the Queen as Head of the Commonwealth, "Message from the Prime Minister of India, Pandit Jawaharlal Nehru, to Her Majesty Queen Elizabeth II, 8 February 1952 in Documents and Speeches on British Commonwealth Affairs 1931-1952, Nicholas Mansergh (ed.) Volume II, London: Oxford University Press, 1953, p 1292
} 
exports. As Graham Wilson has commented: 'No other nation's system of government - certainly not the United States's - has been copied so extensively in such a wide variety of societies and continents. The sun had set on the British Empire but not on Westminster-style government'.2

\section{Westminster Analysed}

The analysis and appraisal of the Westminster model and the countries that are identified as complying with the model's features has been a well-ploughed field of previous research. Majestic studies from earlier scholars like Sir Kenneth Wheare ${ }^{3}$ and Sir Ivor Jennings ${ }^{4}$ helped create an academic discipline from analysing the Westminster system and Westminster countries, which became an especially prominent and practical subject with the eventful and restless advent of decolonisation. In regard to the Westminster system it has been recognised that 'the powers of the Prime Minister or Parliament, the role of political parties, and all the other basic questions asked about the British political system could be studied in settings as different as Canberra, New Delhi and Ottawa as well as Westminster'. 5

It is true that these New Westminsters have developed what Wheare described as a 'constitutional autochthony' ${ }^{6}$, providing an indigenous form and response to 'local' needs. Moreover, the flexibility of the Westminster system readily allows indigenous interpretations and modifications. Commenting on the various connotations and vagaries implied by the Queen's title 'Head of the Commonwealth', a French language paper in Canada proposed that that it was 'in the good British tradition; it is both efficient and devoid of logic'. 7 The statement can be used on the Westminster system itself. It is a hazardous enterprise to formulate a rigid and idealised Westminster model

\footnotetext{
${ }^{2}$ Graham Wilson, "The Westminster Model in Comparative Perspective", in Ian Budge and David McKay (eds.), Developing Democracy, London: Sage Publications, 1994, p 189

${ }^{3}$ For example Sir Kenneth Wheare, The Constitutional Structure of the Commonwealth, London: Oxford University Press, 1960 and Statute of Westminster and Dominion Status, $5^{\text {th }}$ edition, London: Oxford University Press, 1953.

${ }^{4}$ For example Sir Ivor Jennings, The Commonwealth in Asia, London: Oxford University Press, 1951, British Commonwealth of Nations, $4^{\text {th }}$ edition, London: Hutchinson, 1961 and Constitutional Laws of the Commonwealth, London: Oxford University Press, 1957

${ }^{5}$ Wilson, "The Westminster Model in Comparative Perspective", p 190

${ }^{6}$ Autochthony comes from the Greek 'sprung from that land itself' see Wheare, The Constitutional Structure of the Commonwealth, p 89

${ }^{7}$ Vernon Bogdanor, "United Kingdom”, in David Butler and D.A. Low (eds.), Sovereigns and Surrogates

- Constitutional Heads of State in the Commonwealth, New York: St Martin's Press, 1991, p 37
} 
since unlike other constitutional and political models the effort would be largely futile due to the variances and vague conventions that make the system. ${ }^{8}$

Nonetheless, there are still obvious advantages in comparing countries with a common institutional background or heritage. In his comparison of the prime ministerial power in Britain and three other Westminster systems, Weller argues that each has a 'similar political heritage, similar constitutional assumptions, and similar terminology. In each, Cabinet means the same thing and the roles of the Prime Minister are similar, although by no means identical. As a result, the more subtle differences are easier to identify and their impact is easier to assess'. ${ }^{9}$ Weller continues that it is the nature of this unique and devolved political system that fosters such valuable appraisement since:

The Westminster system has always been sufficiently flexible to allow multiple interpretations of what is proper. There is no theoretical model to be adopted. Rather the four systems have sufficient factors in common to allow them to be used to compare and contrast their procedures in such a way as to emphasise the importance of the structural and traditional as well as the changing balance of power. ${ }^{10}$

However, comparative studies of Westminster systems have concentrated on comparisons within two particular classifications or categories of examples. The first and more frequently explored is composed of the 'white' or 'settler' dominions, namely Canada, Australia, New Zealand and sometimes South Africa. Here the reader would be regaled by the experience of the Westminster model in traditional settings populated mainly by British who often saw their new home as 'Better Britain' where the political

${ }^{8}$ Although Patapan, Wanna and Weller 'reject the notion of an idealised Westminster model as of limited analytical value,' they identify in their table of beliefs the five main characteristics of the Executive in a Westminster system:

- $\quad$ The head of state and head of government are two separate roles

- Majority party control of the executive also described as the fusion of the legislature and the executive - with ministers drawn from the parliament

- $\quad$ Concentration of executive power in prime minister and cabinet

- Individual ministerial and collective responsibility to parliament

- Partnership between ministers and neutral officials in which ministers have the last word. R.A.W. Rhodes and Patrick Weller, "Westminster Transplanted and Westminster Implanted: Exploring Political Change" in Haig Patapan, John Wanna and Patrick Weller (eds.), Westminster Legacies - Democracy and Responsible Government in Asia and the Pacific, Sydney: University of New South Wales, 2005, pp 2-6

${ }^{9}$ Patrick Weller, First Among Equals - Prime Ministers in Westminster Systems, Hemel Hempstead:

George Allen \& Unwin, 1985, p 16

${ }^{10}$ Weller, First Among Equals - Prime Ministers in Westminster Systems, p 17 
system had been transplanted ${ }^{11}$ in the new setting, replicating the British model with localised variations. Such grounding would allow a study that not only shared constitutional familiarity but crucially cultural familiarity as well. For it shares a large part of the British historical culture, thanks to its lack of an indigenous historical culture that could replace or crowd-out the one 'brought from the motherland'.

The other category of examples is where the Westminster system had been established through imperial imprimatur, such as in India and Ceylon, thereby creating an implanted $^{12}$ system that continued after the colony's independence from the British Empire but without the same cultural familiarity as the other category experienced because it has an indigenous rather than British historical culture. (Another issue is whether the cultural familiarity is absent at both elite and mass level, and if there is a degree of familiarity at the elite level, whether this assists or actually may hinder the adaptation of these institutions to a country that for the most part lacks cultural familiarity with them.) Like the other New Westminsters, they have 'similar starting points and sets of political institutions but different cultures'. ${ }^{13}$ However, in their case the cultural difference is more marked because they lack the cultural familiarity that the transplanted cases enjoy as cases of 'settler' New Westminsters. This marked difference in cultural backgrounds provides a strong analytical basis for categorising them separately from the transplant cases and as a category of their own - 'the unfamiliar cultural context', implanted category.

\section{The New Westminsters: A Triangular Comparison}

Notable studies have forged valuable research and documentation on transplanted and implanted countries and regions. ${ }^{14}$ Yet rarely have such studies compared and considered both the transplanted and implanted categories together. The value of such analysis is that it allows a study of diverse countries and different cultural backgrounds

\footnotetext{
${ }^{11}$ This distinction is made in Rhodes and Weller, "Westminster Transplanted and Westminster Implanted: Exploring Political Change", pp 1-12

${ }^{12}$ Rhodes and Weller, "Westminster Transplanted and Westminster Implanted: Exploring Political Change", pp 1-12

${ }^{13}$ Rhodes and Weller, "Westminster Transplanted and Westminster Implanted: Exploring Political Change", p 3

${ }^{14}$ A very good Transplanted example is Patrick Weller, First Among Equals - Prime Ministers in Westminster Systems, Hemel Hempstead: George Allen \& Unwin, 1985, which examines the premiership in Canada, Australia, New Zealand and the United Kingdom. While An example from Implanted literature is Amita Shastri and A. Jeyaratnam Wilson (eds.), The Post-Colonial States of South Asia : Democracy, Identity, Development and Security, Richmond: Curzon, 2000 which looks at the major South Asian cases and their post-independent political development.
} 
that are connected by "strong family resemblances"15 in their Westminster-system political institutions. This creates an analytical basis to compare not only countries with countries and regions with regions but also categories with categories. The family nature of the Westminster system means that this can be achieved despite there being different upbringings within the wider family. It also allows a study of the institutions and the cultural influences on institutions to assess how these Westminster 'tools' are used in practice.

Their appraisal bears useful implications for this study, as it is also applicable to the comparative research of the Westminster model in implanted cases and in comparisons across categories. This is an important discernment since it is a comparative study of family resemblances and beliefs, which are evident in the countries chosen rather than a theoretical and definitional study of constitutions which is not easily or productively purloined from Westminster systems - added to this is De Smith's withering reminder that 'the comparison of constitutions by tabulation is perhaps the bleakest form of scholastic aridity... ${ }^{16}$ The comparison will be two-dimensional in the sense of comparing and contrasting not only transplanted with implanted but also a British Westminster institutions with an 'autochthonous' or 'adapted' Westminster institution - that is, a transplanted/implanted 'cultural' comparison and a British Westminster/adapted Westminster institutional comparison.

The adapted Westminster institutions favoured by many of the New Westminsters were normally a federal or quasi-federalised adaptation. It involved not only regional governments but also the whole 'package' of institutional features that is virtually required by federalism: a written constitution that specifies the division of powers between central and regional governments, a relatively powerful judiciary to make binding interpretations of that constitution, a relatively powerful 'regionalised' upper house and potentially a quite powerful Head of State to deal with immediate federal crises. These federalised institutions were adopted by the majority of transplanted cases - Canada, South Africa and Australia - as well as by the key implanted case of India. In fact the institutional contrast could well be phrased as a British Westminster versus Federalised Westminster. However, India made a wider ranging adaptation of

\footnotetext{
${ }^{15}$ Rhodes and Weller, "Westminster Transplanted and Westminster Implanted: Exploring Political Change", p 7

${ }^{16}$ S. A. De Smith, "Westminster's Export Models: The Legal Framework of Responsible Government", Journal of Commonwealth Political Studies, Vol. 1, No. 1, 1961, pp 9-10
} 
Westminster that in addition to federalism introduced a presidential Head of State elected by the central and regional legislatures. So it seems better to present the contrast in terms of British-Westminster versus adapted Westminster, with the implanted case of republican and federalised India being a more 'highly' adapted Westminster than the transplanted cases.

Similarly, the British Westminster institutions were adopted by implanted as well as transplanted cases, notably Ceylon and New Zealand. But this time it was the transplanted case that was more adaptive, as New Zealand introduced a unicameral system within a decade of its legal independence and also gave its Governor-General a wholly ceremonial role as head of state - producing a 'simplified' British-Westminster. (And New Zealand's avoidance of a written constitution is better viewed as part of this simplification of Westminster rather than as part of the influence of a transplanted culture.) In contrast, Ceylon remained true to the British-Westminster bicameralism in a unitary state for decades after independence and departed from British-Westminster institutions only in having a written constitution.

This study will therefore make a triangular analysis of the transplanted simplified British Westminster case of New Zealand with the implanted cases of British Westminster Ceylon and adapted Westminster, republican and federal India.

The analysis will reveal that the cultural complexities of implanted cases include a factor that would have a large impact on the way in which the Westminster institutions were used - namely the different aspects of forms of British Westminster culture adopted by Ceylon and India. To use Bagehot's distinction between 'dignified' and 'efficient' parts of the British Constitution ${ }^{17}$, the Ceylonese political elite had adopted the largely symbolic, ceremonial culture that 'dignified' British institutions while the Indian elite had instead adopted the 'efficient' culture of values and attitudes involved in operating British institutions in a typically 'Westminster' fashion. Paradoxically this would lead to India's republican-federalised adapted Westminster institutions being operated in a more 'Westminster' fashion than Ceylon's British Westminster institutions, as the Ceylon elite was operating British institutions in an anachronistic eighteenth-century manner - such as in having a patronage-based Cabinet dominated by

\footnotetext{
${ }^{17}$ Walter Bagehot, The English Constitution - With an Introduction by R. H .S. Crossman, Glasgow: Fontana/Collins, 1978, pp 61-68
} 
its prime ministerial leader/patron rather than by collegial attitudes or values and in allowing the Governor-General to exercise much more power at times than has any modern British monarch.

To some extent this different cultural 'inheritance' was in turn linked to the institutional and social background of the two cases. (For as Bagehot's term 'efficient' implies, the operating culture is concerned with practical matters of day-to-day government and therefore must be closely 'fitted' to the institutional and social context of governing the country.) In Ceylon's case the weak party institutions and apparent absence of any need for a power-sharing, careful handling of the communal divisions in Ceylon's small and peaceful society had not helped the local elite to become 'acculturated' to Westminster collegiality. And in India the acculturation to Westminster cultural feature of collegiality was aided by the institutional background of a strong Congress party - and also by institutional and social complexities that made the Westminster cultural feature of flexibility seem very appropriate. Such flexibility rather than rule-bound rigidity seemed to the Indian political elite to be essential if the new country was to experience 'good government', especially in light of its post-independence federalism and of the sheer complexity and volatility of India's vast society - whose potential for communal violence had been displayed in the Partition massacres.

In the case of transplanted New Zealand, there seems to have been a strange mixture of acceptance and abandoning of British culture that cut across the dignified-efficient or ceremonial-operational categories. This involved the preservation of such ceremonial, 'dignified' features as parliamentary rituals and great esteem for the Queen as well as such Westminster operational, 'efficient' features as the collegiality associated with 'collective government'. But the local cultural adaptation of valuing 'simplification' led to the operational, 'efficient' downplaying of the Governor-General's role of head of state as well as to the key institutional change of eliminating the 'dignified' upper chamber. As in the implanted case, the acceptance and/or abandonment of British culture was linked to the institutional and social background, as New Zealand was similar to Ceylon in having a 'simple', unitary set of Westminster institutions and a small society with even less communal complexity or division than Ceylon's - as the indigenous ethnic minority had apparently been 'satisfied' with the four Māori seats in parliament rather than power-sharing or a federalist control over Māori-predominant regions. In the New Zealand case the simplifying attitudes and values seemed 
appropriate, and the Ceylon-like attraction to the 'dignified' culture of British Westminster did not extend to protecting such apparently 'unnecessary' institutions as the upper house. If the country had not been developing a pair of strong party institutions, even the Westminster cultural feature of collegiality may have been in danger of a 'simplification' in the direction of institutionalising prime ministerial power rather than merely experiencing a transitory period of personalist government that is typical of democracies emerging from authoritarian or colonial rule.

In fact another compelling reason to compare New Zealand with Ceylon and India is that these three countries are the only examples of transplanted and implanted Westminsters becoming sovereign, independent democracies in the same historical era the late 1940s. For the other transplanted cases had already become independent and the other implanted cases did not become independent until after the 1940s. (It is true that both Pakistan and Burma became independent in the 1940s but they were unable to complete a full democratisation in the years following independence and had declined into military dictatorships by the end of the 1950s.) India and Ceylon became independent in 1947 and 1948 respectively, with India going on in 1950 to become a Republic but retaining its other Westminster features. New Zealand achieved its constitutional independence, meaning a formalisation of its ability to govern itself separately of Britain, with the passing of the 1931 Statute of Westminster in its own Parliament in 1947 (in comparison, Australia had gone through the same constitutional process in 1942, during the war rather than in the aftermath of the war).

In turn, this coincidence of independences provides an opportunity to apply Guillermo O'Donnell's theory of democratising 'delegative' democracy to a mixed group of transplanted and implanted New Westminster parliamentary systems. For the initial years of independent existence as a democracy is when a country is most likely to experience delegative democracy's shift towards a personalist executive that has escaped from the usual forms of 'horizontal' constitutional accountability. ${ }^{18}$ In the Westminster, parliamentary case this would mean that the Prime Minister has escaped from the conventional accountability to the other parts of the executive, namely the head of state and the Cabinet, and had informally established a personalist of 'presidential'

\footnotetext{
${ }^{18}$ Guillermo O'Donnell, Counterpoints - Selected Essays in Authoritarianism and Democratisation, Notre Dame: University of Notre Dame Press, 1999, p 160
} 
executive with the judicial and legislative forms of horizontal accountability seen in formally and rigid presidential systems like the United States of America.

Finally, this initial 'coming of age' period of post-independence democracy may well have been a 'critical juncture' in what became a 'path dependent' influence on the country's political and constitutional history. As will be discussed later in this chapter a 'critical juncture period' is 'critical' since it is often an initial point of institutional creation and experiment when various options and alternatives were available. The directions taken at this juncture are important since it is often hard to change these directions over time once the impact is more pronounced.

The likelihood of 'path dependent' effects is also a compelling reason for the historical analysis of each case separately in addition to its being included in a generalising comparison with other examples. For both these purposes, historical analysis and generalising comparison, the study will focus on the first ten years after independence, which is not only a substantial and feasible, though not overly long period to evaluate but also an accepted indicator of democratic maturity. ${ }^{19}$

\section{Political and Historical Focus: The Westminster Executive}

The particular feature that will be analysed here will be the powers of the Prime Minister and his [all men during the period selected] exercise of executive power under the auspices of the Westminster constitutional system. The Prime Minister's powers will be scrutinised in relation to those of the Governor-General (President in India post1950) and Cabinet. These are the years of development of national executive power, which independence had bequeathed and which now had the opportunity to reveal local cultural conditions, experience tendencies towards delegative democracy and make key decisions that would have a path-dependent effect on the country's political and constitutional history. The Prime Minister's role in these years has a crucial impact on the office and his successors - this can be gauged from the powers and influence of the other key executive players such as the Head of State and Cabinet. The early year

\footnotetext{
${ }^{19}$ Ten years can be seen as a significant time frame for democracies. Stéphane Dion for instance argues that well established democracies can be adjudged to be those 'with at least ten consecutive years of universal suffrage'. Stéphane Dion, "Why is Secession Difficult in Well-Established Democracies? Lessons from Quebec", British Journal of Political Science, Vol. 26, No. 2, April 1996, p. 269 and Sumantra Bose argues that in South Asia 'political patterns which would dominate India, Pakistan and Sri Lanka for decades to come emerged and were consolidated during the first decade' following independence. Sumantra Bose, "Decolonisation and State Building in South Asia", Journal of International Affairs, Vol. 58, No. 1, 2004, pp 95-96
} 
succeeding the end of the World War II and surrounding events in world politics in conjunction with their own independence allowed an extraordinary opportunity in power terms to these political executive actors especially the Prime Minister, which was facilitated by the latent ambiguities of the Westminster system and its application to these foreign contexts and conditions.

The Prime Ministers of India, Ceylon and New Zealand during the time selected were called upon in exceptional circumstances to craft the powers of their office and manoeuvre the machinery of state. The implanted and transplanted Westminsters functioned much the same. The new leaders of the New Westminsters were endowed with the scope and arguably the demand to exercise extraordinary powers. As Andrew Gamble argues that despite the ordeal and ideal that 'the cabinet, the prime minister ... [are] ... subject to parliamentary scrutiny and approval' the Westminster executive has always 'retained its capacity for independent action, leadership and decision'. ${ }^{20}$ And this capacity was certainly on display in the post-independence era of these three New Westminsters.

\section{A Three Level Theoretical Focus on the Three New Westminsters}

This thesis will examine and compare the three case studies from a common theoretical approach. Firstly, each country's cultural background and conditions will be analysed to comprehend not only the context in which Westminster functions, but also more importantly to understand the exercise of power available within the localised social and political arena. The cultural conditions are crucial since they impart directly on the constitutional and political exercise of Westminster executive power and provide a broad picture of the political environment to give an invaluable insight into how the ambiguous and flexible mantra of Westminster was interpreted in local contexts. Secondly, the concept of horizontal accountability and delegative democracy will be tested in the New Westminsters to see how well the purported checks and balances of the Westminster model operate on the executive level in the crucial nation building era. Prime Ministers are unquestionably important, but how well the Cabinet and the Governor-General operate as actors of accountability and how well all three actors conform to the Westminster cultural and institutional expectations of their office is also highly relevant. The actions and inactions of these executive actors of this early era are

\footnotetext{
${ }^{20}$ Andrew Gamble, "Theories of British Politics", Political Studies, Vol. 38, No. 3, September 1990, p 407
} 
fundamental to the future functions and expectations of their offices. Finally, there will be an event or issue selected during this decade, which has path dependent resonance, since it would in future become critical to the operation or complexion of the country. Often this event or issue had not yet been fully appreciated, but had been allowed to develop through the employment of Westminster flexibility and power demonstrating the importance of this critical juncture period. The three level theoretical approach has obvious common elements and therefore are not exclusive of each other, but still form the structural division of the thesis and the basis for the three chapters on each country.

\section{The Three-Level Focus}

\section{Cultural Conditions}

In Hall and Taylor's well-known analysis of 'political science and the three new institutionalisms' it is pointed out that political scientists like to draw a distinction 'between "institutional explanations" based on organizational structures and "cultural explanations" based on an understanding of culture as shared attitudes or values', and it is also pointed out that political scientists tend to define institutions and organisations much more narrowly than sociological institutionalists have done - political scientists have focused on the 'formal rules, procedures or norms' rather than including the 'symbol systems, cognitive scripts and moral templates' that are part of the sociological conception of institutions. ${ }^{21}$ A useful example of a political scientist's narrower focus in their definition of the distinction between political institutions and political culture had already appeared in Orren and Skowronek's suggestions about a 'new institutionalism' in studying American politics.

They defined political institutions as being 'purposive or intentional' in the sense that 'the rules that compose them are constructed and reconstructed with reference to specific goals, thereby distinguishing the rules of political institutions from the more spontaneous regularities associated with political culture'. ${ }^{22}$ Thus institutions have an explicitly tool-like quality that is not found with political culture, which may nonetheless perform important functions - as the anthropologists and others have long pointed out - even though it has arisen spontaneously as operational, 'efficient' attitudes

\footnotetext{
${ }^{21}$ Peter A. Hall and Rosemary C. R. Taylor, "Political Science and the Three New Institutionalisms", Political Studies, Vol. XLIV, 1996, p 947

${ }^{22}$ Karen Orren and Stephen Skowronek, "Beyond the Iconography of Order: Notes for a 'New Institutionalism", in The Dynamics of American Politics - Approaches and Interpretations, Lawrence C. Dodd and Calvin Jillson (eds.), Boulder: Westview Press, 1994, p 327
} 
and values or as ceremonial, 'dignified' symbols or the symbolic preservation of institutions that no longer serve their original purpose or any other operational purpose. Applied to institutional culture this can mean that there may be formal rules but no longer serve their original purpose or role such as perhaps the awesome formal power of the Sovereign (and their representative or parallel) and are no longer maintained by conscious intent.

Difference between British 'dignified', ceremonial culture and Westminster 'efficient', operational culture

The Westminster operational culture comprises the various attitudes and values that evolve spontaneously - without conscious purpose and specific reference to explicit goals - from the operation of Westminster institutions and regardless of the particular national or historical context. For example, it may involve attitudes towards the office of Prime Minister as leader of the government or to the head of state as part of the executive that can be found in any country or in any era since the Westminster system was "up and running". In that sense Westminster operational culture should show as many family resemblances as Westminster institutions. Of course these cultural features can evolve in diverse ways according to the particular situations that arise in particular countries in particular eras - and the path of evolution can take various twists and turns over time - but if these cultural changes go so far beyond the 'Westminster mode' as to change the operation of the institutions in a non-Westminster direction, they can be the basis for a claim that the system has gone beyond the usual range of family resemblances and has become a different form of parliamentary government. For example, if the attitudes towards the Prime Minister or the head of state became too deferential, it could be argued that this Westminster system had moved towards primeministerial rather than cabinet government or - as in the case of Ceylon - had reverted to something akin to the British system of the eighteenth rather than twentieth century. Therefore if political culture 'spontaneously' moves too far away from the Westminster model then the country is no longer a Westminster any more than if the institutions had moved by purposeful reference to specific goals away from the Westminster model.

In contrast, British 'dignified', ceremonial political culture is simply the various attitudes, values and - especially - symbols that have evolved historically in the unique British context but are not necessarily part of the Westminster operational culture. For example, the symbolic rituals of Black Rod pounding on the door of parliament or of 
the new Speaker being dragged to his or her chair are parts of British historical culture that can be transplanted or even implanted in other countries but are not part of the Westminster operational culture. The New Westminsters all sought (including republican India) to take or leave what they wished from British Westminster ceremonial and operational culture as well as from British Westminster institutions, such as cabinet government and a non-elected head of state. In the new contexts of both transplanted and implanted countries the executive actors were 'individuals using local reasoning consciously and subconsciously to reflect on and modify their contingent heritage'. ${ }^{23}$ If the local reasoning was consciously reflecting and modifying their contingent institutional heritage, there was also subconscious reflection and modification of the cultural heritage - with an Indian rejection of the British 'dignified' culture, a Ceylonese rejection of key features of the British 'efficient', operational culture and a New Zealand 'rejection' of some features of both forms of British culture.

\section{Delegative Democracy and Horizontal Accountability}

The phrase coined by Lord Hailsham in 1976 'elective dictatorship' that described the British parliamentary system could have been used much earlier and beyond the Palace of Westminster. As this seasoned observer and participant diagnosed, under the British system you can 'live under an elective dictatorship', which is 'absolute in theory, if hitherto thought tolerable in practice'. ${ }^{24}$ Hailsham pointed to not only the lack of judicial restraints on the sovereignty of parliament but also the fact that in practice parliament had been subordinated to Cabinet and indeed to a powerful minority in Cabinet: 'the whole absolute powers of Parliament ....are wielded by Cabinet alone and sometimes to a relatively small group within the Cabinet'. ${ }^{25}$ If this is the elective dictatorship, it is a dictatorship of the executive. There is clearly no horizontal accountability of the executive to the judiciary or to the legislature. But as the Westminster system does not have a one-person, presidential executive, this still allows the possibility of a horizontal accountability within the executive that can prevent a personal, delegative democracy being set up by the most institutionally powerful person within the executive - the Prime Minister.

\footnotetext{
${ }^{23}$ Rhodes and Weller, "Westminster Transplanted and Westminster Implanted: Exploring Political Change", 
O'Donnell's examination of democratisation and 'delegative democracy' executive power in democratising South America of the 1970s and 1980s has relevance for the situations in which the newly independent New Westminster countries found themselves in the 1940s and 1950s. In particular, he was referring to federal presidential systems, so his analysis is applicable to even the federalised adapted Westminster countries. Though there are obvious differences between the Latin American cases and the Commonwealth ones, the concepts involved help to comprehend theoretically the importance of context on leadership and executive understanding. O'Donnell argues that 'Delegative Democracies are not consolidated (i.e. institutionalised) democracies, but they may be enduring. In many cases, there is no sign either of any imminent threat of an authoritarian regression, or of advances toward representative democracy' ${ }^{26}$

Such states often have to contend with 'the deep social and economic crisis that most of these countries inherited from their authoritarian predecessors reinforces certain practices and conceptions about the proper exercise of political authority that lead to in the direction of delegative, not representative, democracy'. ${ }^{27}$ The political executive's power, in this case the president's, rests 'on the premise that whoever wins election to the presidency is thereby entitled to govern as he or she sees fit, constrained only by the hard facts of existing power relations and by a constitutionally limited term of office ... [the president is] 'the embodiment of the nation and main custodian and definer of its interests.' Intriguingly O'Donnell submits that though 'presidentialism has more affinity with delegative democracy than parliamentarism' nonetheless 'if delegative propensities are strong in a given country, the workings of a parliamentary system could be rather easily subverted'. ${ }^{28}$

Presumably, O'Donnell has in mind parliamentary systems' vulnerability to what Hailsham termed 'elective dictatorship'. In the Westminster system this vulnerability arises from what Hailsham described as 'the absolute powers we confer on our sovereign body, and the concentration of those powers in an executive government formed out of one party which may not fairly represent the popular will' ${ }^{29}$ Westminster executive governments often resemble O'Donnell's 'delegative' presidents who 'present themselves as above both political parties and organised interests' and therefore see

\footnotetext{
${ }^{26}$ O'Donnell, Counterpoints - Selected Essays in Authoritarianism and Democratisation, p 160

${ }^{27}$ O'Donnell, Counterpoints - Selected Essays in Authoritarianism and Democratisation, p 160

${ }^{28}$ O'Donnell, Counterpoints - Selected Essays in Authoritarianism and Democratisation, p 173 - see footnote 11

${ }^{29}$ Hailsham, Elective Dictatorship, p 14
} 
other institutions like the judiciary and legislature as "nuisances that come attached to the domestic and international advantages of being a democratically elected president. Accountability to such institutions appears as a mere impediment to the full authority that the president has been delegated to exercise' ${ }^{30}$ Though such beliefs are 'not alien to the democratic tradition' it is 'less liberal' as electoral contests become 'strongly individualistic, but more in a Hobbesian than a Lockean way: voters are supposed to choose, irrespective of their identities and affiliations, the individual who is most fit to take responsibility for the destiny of the country' this is arguably different in institutionalised democracies where 'accountability runs not only vertically, making elected officials answerable to the ballot box, but also horizontally, across a network of relatively autonomous powers (i.e., other institutions) that can call into question, and eventually punish, improper ways of discharging the responsibilities of a given office. ${ }^{, 31}$ (Within the South American context that O'Donnell has in mind, the key institutions of horizontal accountability are the federal Supreme Court and the houses/chambers of the federal legislature.) O'Donnell argues that the executive during the time of democratic regime building, has 'the apparent advantage of having practically no horizontal accountability... [and] the institutions that make horizontal accountability effective are seen by delegative presidents as unnecessary encumbrances' ${ }^{32}$ This can be directly applied to the cases of the New Westminsters during the time they became sovereign, independent democracies.

\section{Horizontal Accountability and the Legislature}

Hailsham's argument that British Westminster lacks (what O'Donnell later termed) 'horizontal accountability' to the legislature is confirmed by academic analysts of the Westminster system. Arend Lijphart in his scrutiny of government forms in democracies has labelled the Westminster model as being a majoritarian system by making dichotomous contrasts of majoritarian and consensus models, including the executive. The key assessments that is relevant for a Westminster executive is the 'concentration of executive power in single-party majority cabinets versus executive power-sharing in broad multiparty coalitions and the executive-legislative relationships in which the executive is dominant versus executive-legislative balance of power'. Lijphart also stresses the centralisation of power in government, cabinet dominance over the legislature and the concentration of legislative power in a unicameral house rather

\footnotetext{
${ }^{30}$ O'Donnell, Counterpoints - Selected Essays in Authoritarianism and Democratisation, p 164

${ }^{31}$ O'Donnell, Counterpoints - Selected Essays in Authoritarianism and Democratisation, pp 164-165

${ }^{32}$ O'Donnell, Counterpoints - Selected Essays in Authoritarianism and Democratisation, p 166
} 
than decentralised government and legislative power sharing between Houses. ${ }^{33}$ The significance of executive power is intrinsic to the study of any political system. In the Westminster system it is of fundamental consequence.

For all the emphasis that Westminster places on the power and premier place of parliament with the constant venerable adulation of parliamentary sovereignty; and with it the majesty and impartial permanence of the judiciary - it is the executive that is unquestionably primus inter pares over the other branches of state. As R.A.W. Rhodes has observed on the parliamentary aspect the fact that 'all prime ministers must give parliament "some attention" (emphasis in original) attests to parliamentary weakness, not strength. So, key tenets of parliamentary democracy do not work as intended. Such a mismatch between theory and practice will erode the legitimising role of parliament' ${ }^{34}$ With the Westminster system the reality of power is often at divergence with the theory - as in the above case of theoretical parliamentary supremacy. The reality is that parliament with its tight party control in Westminster system does not provide the horizontal accountability that it theoretically could.

\section{Intra-Executive Accountability}

However, any defender of the Westminster system would point out that it does provide a horizontal accountability within the executive that prevents the personalist rule seen in 'delegative' democracies. In Hailsham's terms, it prevents 'elected dictatorship' of the executive being converted into an elected personal dictatorship of the Prime Minister into personalist rule by an elected dictator. As Lijphart describes, the presidential type of executive is a one-person type in which members of the President's Cabinet are 'only advisers to the president' but Westminster and other types of parliamentary cabinet executive are a collective, collegial executive in which members of the Cabinet including the Prime Minister are 'more or less coequal participants' in executive power. ${ }^{35}$ In the Westminster system the only candidate for delegative democracy's personalist rule - the Prime Minister - is joined by and is accountable to the collective Cabinet and the ceremonial-focused Head of State. These two other actors are theoretically able to act as a check on the Prime Minister and thereby apply the principle

\footnotetext{
${ }^{33}$ Arend Lijphart, Patterns of Democracy - Government Forms and Performance in Thirty-Six Countries, New Haven: Yale University Press, 1999, p 3

${ }^{34}$ R.A.W. Rhodes, "Shackling the Leader?: Coherence, Capacity and the Hollow Crown", in Patrick Weller, Herman Bakvis, R.A.W. Rhodes (eds.), The Hollow Crown-Countervailing Trends in Core Executives, London: Macmillan, 1997, p 221

${ }^{35}$ Lijphart, Patterns of Democracy - Government Forms and Performance in Thirty-Six Countries, p 105
} 
of horizontal accountability within the Executive as distinct from the one-person, presidential executive being accountable to the separate institutions of judiciary and legislature.

O'Donnell argues that 'accountability depends on the existence of state agencies that a legally empowered - and factually willing and able - to take actions ranging from routine oversight to criminal sanctions or impeachment in relation to possibly unlawful actions or omissions by other agents or agencies of the state'. He continues that for such checks and 'accountability to be effective, there must exist state agencies that are authorised and willing to oversee, control, redress, and if need be sanction unlawful actions by other state agencies. The former agencies must have not only legal authority but also sufficient de facto autonomy vis-à-vis the latter ... these agencies can only rarely be effective in isolation'. In Westminster systems and in this thesis it is the Head of State and Cabinet that are the 'actors', 'agents' and 'institutions' that act as the intraexecutive agencies of horizontal accountability which prevent personalist rule. Theoretically if these executive actors are 'to be autonomous, institutions must have boundaries, these boundaries must be acknowledged and respected by other relevant actors, and still other actors must be available to defend and eventually redress those boundaries if they are transgressed'. ${ }^{36}$

The accuracy and applicability of this principle horizontal accountability in Westminster systems has always been an issue of contention. Westminster systems have always had difficulty in defining the powers and parameters of its institutions due to their predilection for custom and convention over precise constitutional articulation. As shall be shown, New Westminster constitutions are 'often adopted without much variation the institutional ensembles already familiar to them from the formal or informal empire to which they belonged'. The New Westminsters 'have looked to transplanted laws and constitutions to serve as engines of political and economic modernity, sparking persistent and often heated debates over the gap thus created between the pays légal and the pays réel. This gap - long discussed by politicians, historians, novelists, and social scientists - between formal rules and what most people most of the time actually do, has

\footnotetext{
${ }^{36}$ Guillermo O’Donnell, "Horizontal Accountability in New Democracies", Journal of Democracy, Vol. 9, No. 3, 1998, pp 117-119
} 
raised never-ending debates as to whether it would be better firmly to establish the pays légal or organise political life around the pays réel' ${ }^{37}$

This concern is of crucial importance during the early years of independence, where the perimeters of institutions and power actors are especially ambiguous and more often than not without specific legal jurisdictional force. The resulting situation is one of fluidity and uncertainty that leaves horizontal accountability in a potentially unstable and unsatisfactory state of effectiveness that in turn facilitates 'high personalisation and concentration of power in the executive'. ${ }^{38}$ In a New Westminster this will likely take the form of a personalised concentration of power in the hands of the Prime Minister and a lack of horizontal accountability to the other components of the executive Cabinet and Head of State.

\section{Horizontal Accountability of Prime Minister to Cabinet}

The tendency towards personal leadership is evident in any new democracy, whether after a process of democratisation or of decolonisation under democratic auspices. In fact in the democratising aftermath of Germany's defeat in the First World War, there was a call from Max Weber for a 'plebiscitary type of leadership' - a Fuehredemokratie (leader democracy) - that he initially envisaged would take prime-ministerial form but later envisaged as a strong presidential system. ${ }^{39}$ In a sense therefore he was the first theorist of delegative democracy, in both prime-ministerial and presidential forms, and is a reminder of how 'universal' a tendency it seems to be - to look for personal leadership rather than an institutionalisation of constitutional, horizontal accountability as well as vertical, democratic accountability.

Schumpeter's observations on the British political system and therefore the Westminster style of government have resounding implications for this study with its emphasis on leadership power. Schumpeter noted that that the 'British electorate, as in any parliamentary democracy, did not elect - and thus produce - a government' since as he perceived it the electorate actually 'devolves' the 'government-producing function to an intermediate organ, henceforth called parliament - and thereby allows parliament on

\footnotetext{
${ }^{37}$ O'Donnell, Counterpoints - Selected Essays in Authoritarianism and Democratisation, p 116

${ }^{38}$ O'Donnell, Counterpoints - Selected Essays in Authoritarianism and Democratisation, p 170

${ }^{39}$ Cited from Paul Brooker, Leadership in Democracy - From Adaptive to Entrepreneurial Initiative, Houndmills: Palgrave Macmillan, 2005, p 11
} 
their behalf to form the government, which in turn acknowledges an individual leader with a leadership that is to some extent independent of mere party opinion' ${ }^{40}$

Schumpeter argued long ago that Cabinet is a 'miniature parliament' consisting not only 'of comrades in arms but of party men who have their own interests and prospects to consider'. So some de facto horizontal accountability to a 'parliament' may still exist in this miniature, intra-Cabinet form. And as Schumpeter's conception of parliament was as a chooser of governments, he was implying that the Cabinet could hold the Prime Minister accountable through its power to remove him from his post - a form of accountability that is rather different from the vetoing form of accountability found in presidential systems. ${ }^{41}$ From the Prime Minister's perspective the sword of Damocles hanging over him requires that he take careful note of the anticipated responses of his Cabinet colleagues to his actions. As Schumpeter put it, the Prime Minister must 'shape his program so that his colleagues in the Cabinet will not too often feel like "reconsidering their position" ... [and] steers a middle course between insisting on discipline and allowing himself to be thwarted. He tempers pressure with more or less judicious concessions'. 42

\section{Horizontal Accountability on Prime Minister to Head of State}

Ludger Helms has examined the powers of executive leadership in Presidents, Prime Ministers and Chancellors - Executive Leadership in Western Democracy. Helms concentrates on the 'politics of executive leadership' since it is this, he argues, which 'matters significantly for the overall performance of contemporary democracies. ${ }^{43}$ Helms utilises the distinction of executive power from Harold Laski with his formulation of the 'constitutional executive' and the 'political executive' ${ }^{44}-$ in the Westminster system this is a crucial and much lauded distinction theoretically though in practice the division is more nebulous.

\footnotetext{
${ }^{40}$ Joseph Schumpeter, Capitalism, Socialism and Democracy, New York: Harper Edition, 1974 pp $273-$ 276 and Brooker, Leadership in Democracy - From Adaptive to Entrepreneurial Initiative, p 18

${ }^{41}$ Schumpeter, Capitalism, Socialism and Democracy, p 278 and Brooker, Leadership in DemocracyFrom Adaptive to Entrepreneurial Initiative, $\mathrm{p} 18$

${ }^{42}$ Schumpeter, Capitalism, Socialism and Democracy, p 281 and Brooker, Leadership in DemocracyFrom Adaptive to Entrepreneurial Initiative, p 19

${ }^{43}$ Ludger Helms, Presidents, Prime Ministers and Chancellors - Executive Leadership in Western Democracy, Houndsmills: Palgrave Macmillan, 2005, pp 3-4

${ }^{44}$ Helms, Presidents, Prime Ministers and Chancellors - Executive Leadership in Western Democracy, $\mathrm{p}$ 9
} 
De Smith used head of state versus government relationship as an example of the uniquely Westminster arrangement of constitutionally fusing the specifics of legal doctrines and the supple qualities of conventions, which he described as a 'voluntary schizophrenia', as 'in the main the dichotomy of law and convention was preserved, and most of the really important conventions left to the interpolator'. ${ }^{45} \mathrm{He}$ argued that the nature of the relationship between the Governor-General (or a 'constitutional' President) and their Ministers is "inherently unsuitable for codification, whether in the form of legally binding rules or as a set of directive gubernatorial policy'. ${ }^{46}$ The Head of State is ultimately the last check on the executive and is the guardian of the constitution in Westminster systems and can theoretically veto the 'political executive' though this is normally a dormant power, it is nonetheless a horizontal accountability power. ${ }^{47}$

The crucial power of the Prime Minister over Cabinet or the Head of State can be seen as Poguntke and Webb argue 'as the development of (a) increasing leadership power resources and autonomy within the party and the political executive respectively and (b) increasingly leadership-centred electoral processes'. In any system 'presidentialization' meaning centralised and largely autonomous power is determined and highly constrained by the formal configuration of political institutions. In other words, different regime-settings provide institutions and actors with different power resources, thus constraining correspondingly the potential space for movement'. ${ }^{48}$ The Westminster model provides various actors with a great potential of increasing power autonomy over the others due to high level of flexibility and manoeuvrability. The "regime-settings" available in New Westminsters in their early independence eras displayed a high potential for varying degrees for political actors to settle on the power continuum generally unencumbered by fixed and formal institutional expectations. This time allowed the countries and their executive, particularly the Prime Minister, the ability to mould and establish constitutional traditions, which in turn fostered itself upon the nascent polity that surrounded the real and constitutional independence. The new

\footnotetext{
${ }^{45}$ De Smith, "Westminster's Export Models: The Legal Framework of Responsible Government”, p 4

${ }^{46}$ De Smith, "Westminster's Export Models: The Legal Framework of Responsible Government", p 10

${ }^{47}$ Sir Ivor Jennings, Cabinet Government, $3^{\text {rd }}$ edition, Cambridge: Cambridge University Press, 1959, $\mathrm{p}$ 412 and the Indian President's oath requires him to 'preserve, protect and defend the Constitution'. Article 60, in Durga Das Basu, Constitutional Law of India, $7^{\text {th }}$ edition, New Delhi: Prentice-Hall, 1998, p 145

${ }^{48}$ Thomas Poguntke and Paul Webb, “The Presidentialization of Politics in Democratic Societies: A Framework for Analysis" in The Presidentialization of Politics - A Comparative Study of Modern Democracies, Thomas Poguntke and Paul Webb (eds.), Oxford: Oxford University Press, 2005, pp 5-6
} 
executive political actors legitimately became the midwife to their newly christened and adopted Westminsters once delivered from the mother of Parliaments.

\section{Path Dependency and Critical Juncture}

A further reason for examining these countries during the period succeeding independence is the legacy that era has on further generations and whether the potential propensities outlined above establish themselves and create path dependence. James Mahoney argues

path dependence characterises specifically those historical sequences in which contingent events set into motion institutional patterns or event chains that have deterministic properties. The identification of path dependence therefore involves both tracing a given outcome back to a particular set of historical events, and showing how these events are themselves contingent occurrences that cannot be explained on the basis of prior historical conditions. ${ }^{49}$

How great was the impact of the early years of independence and the leaders who were at the helm who presided over policy and their countries nascent institutions? At the very least it can be argued that "periods of institutional genesis correspond to "critical junctures". They are "critical" because 'once it becomes progressively more difficult to return to the initial point when multiple alternatives were still available' and therefore at this time the 'initial steps in a particular direction induce further movement in the same direction such that over time it becomes difficult or impossible to reverse direction'. 50 "Critical junctures" can be obvious such as independence in India's case but are not always so. As Paul Pierson argues 'the necessary conditions for current outcomes occurred in the past. The crucial object of study becomes the critical juncture or triggering events, which set development along a particular path, and the mechanisms of reproduction of the current path - which at first glance might seem commonplace or at least uninteresting, ${ }^{51}$ New Zealand's adoption of the Statute of Westminster is an example of a "commonplace" juncture that was not wholly appreciated then or now as one that ushered a series of considerable constitutional change.

\footnotetext{
${ }^{49}$ James Mahoney, "Path Dependence in Historical Sociology" Theory and Society, Vol. 29 No. 4, August 2000, pp 507-508

${ }^{50}$ Mahoney, "Path Dependence in Historical Sociology", pp 512-513

${ }^{51}$ Paul Pierson, "Increasing Returns, Path Dependence, and the Study of Politics", The American Political Science Review, Vol. 94, No. 2, June 2000, p 263
} 
The path dependent theory needs a starting point or 'temporal location of initial conditions in a sequence'. ${ }^{52}$ In this thesis the 'temporal' point is the time of independence, when the sequence events and 'critical juncture period' begins. The institutions implanted or transplanted are now under sovereign direction and ownership of the New Westminsters. The machinery of power is available to its new masters sometimes regardless of past practices. ${ }^{53}$ The potential for executive actors to utilise this era and uncertainty is palpable. However, this does not mean that the actions of executive actors and the surrounding institutions are predictable. There were many expectations and burdens on the new leaders and on the New Westminsters themselves. The new leaders often did not realise the strong possibility that the implications of political decisions - especially complex policy interventions [e.g. Communalism in Ceylon] or major institutional reforms [e.g. Nehru's acquiescence to federalism on linguistic lines] only play out in the long run. Yet political actors, especially politicians, would often seem most interested in the short-term consequences of the actions [eg. New Zealand's abolition of the Upper House as a party political point]; long term effects may be heavily discounted' when analysing the past actions of the executive. ${ }^{54}$

During a 'critical juncture period' like the years adjacent to independence there are times of 'contingency', which in path dependent theory 'refers to the inability of theory to predict or explain, either deterministically or probabilistically, the occurrence of a specific outcome. A contingent event is therefore an occurrence that was not expected to take place, given certain theoretical understandings of how casual processes work' ${ }^{55}$ Indeed as Pierson stresses 'we should turn to history because important aspects of social reality can best be comprehended as temporal processes. It is not the past per se but the unfolding of processes over time that is theoretically central' because path dependency stresses 'critical moments in politics, distinctive developmental sequences, and rigidities that make it difficult for social actors to escape from established paths'. 56

\footnotetext{
${ }^{52}$ Mahoney, "Path Dependence in Historical Sociology", pp 536-537

${ }^{53}$ Indeed the 'genesis of an institution is not a predictable outgrowth of pre-existing power arrangements. Once the institution develops, however, it is reinforced through predictable power dynamics: the institution initially empowers a certain group at the expenses of other groups; the advantaged group uses its additional power to expand the institution further; the expansion of institution increases the power of the advantaged group; the advantaged group encourages institutional expansion.', Mahoney, "Path Dependence in Historical Sociology", p 521

${ }^{54}$ Paul Pierson, "The Limits of Design: Explaining Institutional Origins and Change", Governance: An International Journal of Policy and Administration, Vol. 13, No. 4, October 2000, p 479

${ }^{55}$ Mahoney, "Path Dependence in Historical Sociology", p 513

${ }^{56}$ Pierson, "Increasing Returns, Path Dependence, and the Study of Politics", pp 264-265
} 
Such periods can lead to a 'lock-in' of a given institutional pattern, 'making it extremely difficult to abolish' and some institutions are 'especially capable of seizing opportunities provided by contingent events and thus setting into motions selfreinforcing sequences that are path-dependent'. ${ }^{57}$ All the New Westminsters analysed developed their own legacies and mutations, many of which were not foreseen, and in certain extreme cases, were not wanted - and yet all these countries still live with the inheritance and consequences of that critical era. As Pierson contends political history counts -

To see where functional accounts might come up short one needs to look not just at the moment of institutional origins, or at a current institution. Instead, one must consider dynamic processes that can highlight the implications of shorttime horizons, the scope of unintended consequences, the emergence of path dependence, and the efficacy or limitations of learning and competitive mechanisms. This requires genuinely historical research. ${ }^{58}$

\section{Path Dependent Case Examples in the New Westminsters}

All three countries selected for this thesis display key aspects of path dependence that occurred in the 'critical juncture period' that followed independence. It is not possible to examine every point of path dependence so one major issue or event was selected that continues to politically and constitutionally resonate consciously or unconsciously in the each country well after independence in the late 1940s. The abolition of the Legislative Council, New Zealand's upper house of Parliament, is an example of a 'critical' event that was not greatly appreciated at the time, but in fact demonstrated the minimal forms of constitutional accountability in New Zealand and commensurate powers available to a New Zealand Prime Minister. The issue of communalism is hard to avoid in today's Sri Lanka and yet there were chances and opportunities to at least place institutional checks to mitigate minority fears when they were manageable and all groups participatory in the first decade following independence. Instead politicians had 'short term time horizons' and embarked on immediate political gain, which maximised the difficulty of reforming the situation. India's mighty polity is held together today by its unique federal structure, which resulted from various unintended forces such as

\footnotetext{
${ }^{57}$ Mahoney, "Path Dependence in Historical Sociology", pp 513-515

${ }^{58}$ Pierson, "The Limits of Design: Explaining Institutional Origins and Change", p 494
} 
Partition and the Princely States, but also Nehru's centralised leadership with the gradual formation of states on ethnic and linguistic lines during the early years, which remarkably accommodated India's plethoric plurality.

The subjects chosen above legitimise the description of the period as a "critical juncture period'. However, it is well beyond the scope and objective of this thesis to examine all the consequences of this period. Instead the main aim of the path dependent and critical juncture theory is to demonstrate the importance of this selected period as a continuing and relevant focus of analysis due to the significance of the events, choices and context of the post-independence decade. 


\section{Mixed Messages?: Indian Responses to its British Legacy}

Jawaharlal Nehru delivered to the Constituent Assembly a resonant and erudite speech to usher in India's independence at midnight 14-15 August 1947:

Long years ago we made a tryst with destiny, and now the time comes when we shall redeem our pledge, not wholly or in full measure, but very substantially. At the stroke of the midnight hour, India will wake to life and freedom. A moment comes, which comes but rarely in history, when we step out from the old to the new, when an age ends, and when the soul of a nation, long suppressed finds utterance. It is fitting that at this solemn moment we take the pledge of dedication to the service of India and her people and the still larger cause of humanity. ${ }^{59}$

Nehru's words articulated the momentous achievement of attaining independence from Britain after an often bloody and violent struggle of mass proportions, which only India's unique cultural conditions could generate.

Gandhi had mobilised the masses with unique dexterity and effectiveness and projected India's pursuit for freedom to the world and thus became an international figure of influence and importance and for the majority of Indian people he was their supreme Mahatma. Gandhi had long advocated the genius of Indian civilisation and sought to draw upon India's ancient axioms and imbue them into the twentieth century as an answer to modernity and western civilisation. ${ }^{60}$ The ideas of this iconic sage were not restricted to merely to social topics such as the symbolic spinning of yarn but also to the field of governance. Gandhi had a radical plan to completely disestablish the British centralised government and create localised "village republics" to provide "real" democracy. Despite his extraordinary appeal in the country his wishes were not actualised.

\footnotetext{
${ }^{59}$ Jawaharlal Nehru, "Tryst with Destiny", 14 August 1947, in The Essential Writings of Jawaharlal Nehru, Vol. 1, S Gopal and Uma Iyengar (eds.), New Delhi: Oxford University Press, 2003, pp 346-347

${ }^{60}$ For a useful examination of Gandhi's ideas see Bhiku Parekh, Gandhi's Philosophy: A Critical Examination, Notre Dame: University of Notre Dame Press, 1989
} 
Instead India retained the governmental essence and structure of the departed Imperial power system, albeit crucially with an Indian interpretation. Nehru's speech correctly emphasised a nationalistic and Indian cadence, but India's political institutions would implant and borrow substantially from abroad - especially the Westminster system. Ten years after Nehru's speech the first President of the Indian Republic, Dr Rajendra Prasad, told visiting Commonwealth Parliamentary delegates in New Delhi that 'we have all derived from the British Parliament, and we still continue to derive inspiration from its proceedings, from its history [and] from its traditions'. ${ }^{61}$ However, constitutionally India borrowed more from Bagehot's 'efficient', operational parts of Westminster institutions while conspicuously, as a Republic, eschewing British culture and the 'dignified' ceremonial trappings normally seen in the New Westminsters.

Though it is not within the scope or intention of this chapter to detail India's arduous freedom struggle, it is suffice here to point out that the long struggle for freedom that India's political leaders entered in to naturally moulded their political beliefs and motives as well as the complexion of post-independent polity of not only India. This was a world event especially for the vast territories and inhabitants that spanned most of globe and endured under some colonial yoke. With the loss of India the British Empire was never, and could never, be the same again. The Imperial ideal of timeless suzerainty over the subcontinent was destroyed, and the fall of Britain's great empire now became inevitable. As Jan Morris explains, 'half the structure of Empire was mere scaffolding for the possession of India. Many a possession now lost its point, and the British attitude to the world, governed so long by the great possessions of the east, slowly and painfully shifted. "If India becomes free," Gandhi told Roosevelt in 1942, "the rest will follow." So it was, and after 1947 the British Empire was in a constant condition of dismantlement' ${ }^{62}$ This was a revolutionary event appreciated by India. India's nationalist leaders' long experience of incarceration, indignity and disappointment had fostered their ideals for governing the newly independent nation.

But India's indigenous leaders 'believed wholeheartedly in democracy and parliamentarianism'. In short 'they wanted the British out, but were prepared to adopt

\footnotetext{
${ }^{61}$ President Prasad to the Commonwealth Parliamentary Conference, New Delhi, December 1957 - cited in Granville Austin, Working a Democratic Constitution - The Indian Experience, New Delhi: Oxford University Press, 1999, p 11

${ }^{62}$ Jan Morris, Farewell the Trumpets - An Imperial Retreat, London: Faber and Faber, 1998, p 495
} 
their institutions' and the new constitution of India made a 'sharp break with the British colonial past, though not with British political practices' and institutions. ${ }^{63}$ Therefore, India did not actually launch into a completely new constitutional era at independence that was diametrically opposed the previous colonial condition and was not contemptuous of the constitutional theories of the preceding power. Though India's achievement of independence was a remarkable and groundbreaking event in constitutional terms it can be argued that India's independence was another significant step in the evolution of constitutional representative government dating from such developments as the Indian Councils Act of 1861 and the Montagu-Chelmsford Reforms of 1919 and especially the Government of India Act of 1935.

Aspects of this crucial Imperial inheritance or implantation will be discussed further below. India had demanded and Britain had answered in staggered sequence with constitutional reforms that acculturated the concepts of parliamentary democracy, federalism (which was more a feature of New Westminsters; certainly not British Westminster) and devolved limited executive power to elected representatives. ${ }^{64}$ The size and importance of India, not only for the British Empire, meant that its path to independence would have massive and conspicuous influence. Despite the imperial legacy, India's virulent freedom struggle, bloody partition and Gandhian embrace meant that its independence could only be unique in the annals of the Empire - the constitution would be no exception. India's masses and nationalist leaders had insisted with dramatic effect since the 1930s the right to govern themselves - they eventually chose to govern the Westminster way. India brought to the world the catharsis of decolonisation - and also with its nationalist credentials established Westminster parliamentary government as a model for new states in the Commonwealth since India was the first to gain independence from Britain in Asia or Africa and had no non-settler examples to emulate. As was written in the Manchester Guardian ten years after India gained independence with the unravelling of Empire in the fore: 'All that is happening in Asia throws a spotlight on the Parliament in Delhi as the one institution of the kind which is working in an exemplary way ... Pericles said that Athens was the school of Hellas. Mr Nehru without boasting may say that Delhi is the school of Asia' ${ }^{65}$

\footnotetext{
${ }^{63}$ Paul R. Brass, The Politics of India since Independence, $2^{\text {nd }}$ edition, Cambridge: Cambridge University Press, 2001, pp 2-11

${ }^{64}$ For a well documented study of India's constitutional evolution during the colonial era see B. Shiva Rao, The Framing of India's Constitution - A Study, Bombay: The Indian Institute of Public Administration, 1968

${ }^{65}$ Cited in W. H. Morris-Jones, Parliament In India, London: Longmans, Green and Co, 1957, p 327
} 
India indeed had lessons for Asia, the world and the Westminster system. But in 1947 the great gamble of Attlee, Nehru and Mountbatten was far from promising an assured outcome. One scholar contends that by at least four political theories on democracy concerning political culture, societal cleavages, socio-economic factors and class upheaval, India in 1947 had the conditions necessary to bring about the 'demise of democratic institutions' and yet stable Westminster institutions such as parliament, an independent judiciary, a robust electoral system and a federal structure today 'remain intact - bruised and modified - but intact'. ${ }^{66}$ Despite such an appreciation of English political influence India's incomparable social situation and the nationalist rhetoric from its leaders meant that India had to succeed and keep unified and provide for the aspirations of its people. India was the audacious attempt of an adapted Westminster. Sir Anthony Eden commented after a visit to independent India during the Nehru era the excitement and gamble of adapting Westminster culture and institutions to Indian soil:

Of all the experiments in government which have been attempted since the beginning of time, I believe that this Indian venture into parliamentary government is the most exciting. A vast sub-continent is attempting to apply to its tens and hundreds of millions a system of free democracy which has been slowly evolved over the centuries in this small island. It is a brave thing to try to do and is so far remarkably successful. The Indian venture is not a pale imitation of our practice at home, but a magnified and multiplied reproduction on a scale we have never dreamt of. ${ }^{67}$

Constitutionally, unlike Ceylon, they demanded and received the authority to convene a Constituent Assembly to achieve and formulate their own nationalist and political goals. Democracy needed to deliver and to assure the masses. Constitutionally the Congress elite had "to counter persistent British claims of being paternalist, impartial benefactors who were better guardians of "real" Indian masses, and in particular of minorities, against a "microscopic minority" of privileged Hindu politicians'. ${ }^{68}$ The Gandhian

\footnotetext{
${ }^{66}$ Myron Weiner, “The Wounded Tiger: Maintaining India's Democratic Institutions” in Transfer and Transformation: Political Institutions in the New Commonwealth, Peter Lyon and James Manor (eds.), Cambridge: Leicester University Press, 1983, pp 49-51

${ }^{67}$ Sir Anthony Eden, The Memoirs of the Rt. Hon. Sir Anthony Eden K.G., P.C., M.C. - Full Circle, London: Cassell, 1960, p 222

${ }^{68}$ Sumit Sarkar, "Indian democracy: the historical inheritance" in The Success of India's Democracy, Atul Kohli (ed.), Cambridge: Cambridge University Press, 2001, p 30
} 
movements had engaged the masses to a degree that heralded the inevitability of Britain surrendering its greatest possession, but it also raised the expectations from its people of its leaders. India now was an independent Dominion, though a Dominion like no other, not even like the South Asian cases of Pakistan or Ceylon. Dominionhood was seen as an 'imperialist device' and a mere transitory step before throwing off even the nominal symbolic shackles of having the British Monarch continue as Head of State.

Even before the formal handover in August the Constituent Assembly had resolved on 22 January 1947 the objective to become an 'independent sovereign republic' and avoid any temptation to continue symbolically any 'dignified' ceremonial vestments of British constitutional culture, preferring instead to adapt the 'efficient' operational elements of Westminster culture. ${ }^{69}$ After centuries of foreign despotic rule and in the midst of anarchic disorder and terror following Partition it was not unnatural for India's leaders to concern themselves with the issue of executive power over a teeming multitude and mixture of masses. In Philadelphia, 160 years earlier, a similar Constitutional Convention gathered and considered such crucial matters. A description of the American atmosphere in 1787 reflected the dilemmas in Delhi in 1947:

Over the whole convention still hung the dread of future tyranny as well as of immediate anarchy. The delegates were sure that unless anarchy could be avoided, an early despot was certain to appear, as in the classic pattern of republican failure. They believed that anarchy could be at least postponed by the establishment of an adequate central government, but they could only guess what powers would make it neither too weak for security nor too strong for liberty. $^{70}$

India's leaders and Constituent Assembly had an unprecedented and unenviable task in shaping their country through its Constitution and attempting to create an Executive that reflected the multiple needs of their new nation and wondered whether Nehru would be their Westminster Washington.

\footnotetext{
${ }^{69}$ Objectives Resolution in Shiva Rao, The Framing of India's Constitution - A Study, pp 121-122 and R. J. Moore, Making the New Commonwealth, Oxford: Oxford University Press, 1987, pp 244-255

${ }^{70}$ Cited in Granville Austin, The Indian Constitution: Cornerstone of a Nation, Oxford: Oxford University Press, 1966, p 127
} 


\section{Constituent Assembly - Continuity or Change?}

The context with which the Constituent Assembly operated and its findings allow a useful analysis of India's cultural conditions. Nehru had always strived for a nation composed of different religions and ethnicities or as he phrased it a 'composite nationality'. ${ }^{71}$ India would emerge in 1950 after the Constituent Assembly had ended its deliberation with a composite constitution - albeit with a Westminster institutional bias. Indeed, India's premier constitutional scholar, Sir Benegal N. Rau, who became the Constitutional Adviser to the Constituent Assembly, stated that 'anyone whose official life has been spent mostly in the administration of justice and the study of constitutions is bound to have certain prepossessions, for in these spheres one sees English institutions and ideas at their best and is most conscious of what India owes to them' and pronounced a perception common to those elite Indians in politics and government that 'the English parliamentary system of government has become almost second nature to us' ${ }^{72}$ Despite this, the emergence of a Westminster parliamentary democracy was not a foregone conclusion. When the 296 members of the Constituent Assembly sat for the first time in New Delhi on 9 December 1946 they appreciated, as one of their members recorded, that it was 'an event of unique significance, namely the commencement of the great task of framing free India's constitution without outside interference or pressure'. ${ }^{73}$

And yet the Assembly itself was in many ways ordained by the British - albeit as a response to prominent Congressmen like Nehru. Important Britons like Sir Stafford Cripps had endorsed the idea in 1942 to the War Cabinet in London and when Labour was resoundingly elected in 1945 he helped establish a Cabinet Mission to India, which had the prime objective of assisting 'the Viceroy in setting up in India the machinery by which Indians can devise their own constitution' through a Constituent Assembly, which was convened by the Viceroy himself. ${ }^{74}$ The validity, powers, premise and fidelity of the body was questioned from the outset, especially with the boycott enacted by Jinnah's Muslim League, which questioned (along with Winston Churchill), whether such a body was valid and technically the British had the power to dissolve it or even reject its conclusions. ${ }^{75}$

\footnotetext{
${ }^{71}$ Judith M. Brown, Nehru - A Political Life, London: Yale University Press, 2003, p 177

${ }^{72}$ B. N. Rau, India's Constitution in the Making, Madras: Orient Longmans, 1960, p 342

${ }^{73}$ Shiva Rao, The Framing of India's Constitution - A Study, p 1

${ }^{74}$ Austin, The Indian Constitution: Cornerstone of a Nation, pp 3-7

${ }^{75}$ M.V. Pylee, Constitutional Government in India, $3^{\text {rd }}$ edition, Bombay: Popular Press, 1977, p 140
} 
However, the creation of Pakistan and the Indian Independence Act passed by the British Parliament Westminster, which came into effect on 15 August 1947 settled the legality and authenticity of the situation, which the Constituent Assembly had assumed anyhow and this elite legislative body resolutely continued to deliberate and form a constitution for the new state of India (until the new Constitution was complete the Indian Independence Act resolved that the Government of India Act 1935 would remain the basis of government and thus India already had a parliamentary system before the Constituent Assembly determined so). ${ }^{76}$ In fact the Assembly members had to deal with donning two hats to signify their creative function. As Austin states as 'the Constituent Assembly, it drafted the Constitution during the afternoon, and in the morning, as the Constituent Assembly (Legislative), it was the Provisional, or Dominion, Parliament legislating for the new nation'. ${ }^{77}$

The composition of the Constituent Assembly was determined through indirect elections in the provincial legislatures in July 1946. The Congress and its supporters dominated the new Assembly, which was further augmented with Partition as the party's presence was aggrandised from an already colossal sixty-nine per cent to an overwhelming eighty-two per cent majority once most of the Muslim League departed with the creation of Pakistan; it was no exaggeration to claim that 'the Assembly was the Congress and the Congress was India' ${ }^{78}$ According to one constitutional expert, the reality was that 'Nehru, [Vallabhbhai/Sardar] Patel, Prasad, and [Abul Kalam/Maulana] Azad, in fact, constituted an oligarchy within the Assembly. Their honour was unquestioned, their wisdom hardly less so...The oligarchy's influence was nearly irresistible, yet the Assembly decided issues democratically after genuine debate, for it was made up of strong-minded men and the leaders themselves were particularly responsive'. ${ }^{79}$ Another South Asian specialist, Ayesha Jalal contends that the Dominion Government of Nehru and his Congress vanguard's 'inheritance of the centralised state apparatus of the Raj facilitated its task of shaping independent India's constitution. Pandering to the values of consensus and accommodation as well as speech-making by a large number of members notwithstanding, the substance of the constitution was

\footnotetext{
${ }^{76}$ Austin, The Indian Constitution: Cornerstone of a Nation, p 8

${ }^{77}$ Austin, Working a Democratic Constitution, p 5

${ }^{78}$ Austin, The Indian Constitution: Cornerstone of a Nation, pp 9-10

${ }^{79}$ Austin, The Indian Constitution: Cornerstone of a Nation, pp 9-22
} 
decided upon by a small coterie of about a dozen individuals led by Jawaharlal Nehru and Sardar Patel'. ${ }^{80}$

The Constituent Assembly, though highly representative on political, religious, ethnic and regional grounds was hardly a mirror of the masses in terms of political education, institutional cognisance and experience. The favoured representatives that populated the vital and voluble Constituent Assembly had through their social stature, education and vocations notable, if not extensive, experience of British parliamentary theory and practice, which lent undoubted cultural flavour to the proceedings and gave as Jalal argues 'short shrift to Gandhian ideas of self-governing village republics, other than a purely cosmetic gesture to panchayati raj [form of localised government] in favour of strong central government of the parliamentary form. ${ }^{81}$ The elite body rejected historic indigenous innovation in favour of a modified Westminster institutional structure. The scholarly and influential K. M. Munshi, one of the seven members of the powerful Drafting Committee, eloquently expressed this preference for Westminster style institutions when he reminded the Assembly of India's familiarity with British parliamentary government:

We must not forget a very important fact that during the last one hundred years Indian public life has largely drawn upon the traditions of the British constitutional law. Most of us, and during the last several generations before us, public men in India, have looked up to the British model as the best. For the last thirty or forty years, some kind of responsibility has been introduced in the governance of this country. Our constitutional traditions have become parliamentary and we have now all our provinces functioning more or less on the British model. As a matter of fact, today, the Dominion Government of India is functioning as a full-fledged parliamentary government. ${ }^{82}$

Nonetheless, Rau, as Constitutional Adviser, was entrusted to present information on the constitution and constitutional practices from a wider pool than just Britain. Rau visited the United States, Canada, Ireland as well as Britain in late 1947 to question Presidents, Prime Ministers, legislators, law experts and civil servants on their particular

\footnotetext{
${ }^{80}$ Ayesha Jalal, Democracy and Authoritarianism in South Asia - A Comparative and Historical Perspective, Cambridge: Cambridge University Press, 1997, p 33

${ }^{81}$ Jalal, Democracy and Authoritarianism in South Asia - A Comparative and Historical Perspective, $\mathrm{p}$ 33

${ }^{82}$ Cited in Shiva Rao, The Framing of India's Constitution - A Study, p 337
} 
constitutions and to assess their virtues and applicability for independent India. ${ }^{83}$ Along with those countries' experiences Rau affixed the practices prevalent in polities such as France, Switzerland, Australia, South Africa and even the complex, but interesting multinational workings of Austria-Hungary under the Hapsburg Empire as examples to fill his thorough memoranda to Assembly members on their potential appropriateness for India.

Indian forms of governance were largely ignored in this academic exercise or utilised to prove the worthiness and autochthony of parliamentary and especially cabinet government for India. Indian historical culture, rather than British historical culture, was creatively used to justify Westminster institutions for India. The sophisticated savant Rau was able to produce for local consumption evidence derived from the sacred texts of ancient India to lubricate his advocacy for the adoption and selective implantation of British practices. From the Sukraniti, which dates from the twelfth century, Rau recites an ancient axiom that 'without the ministers, matters of State should never be considered by the King, even if he is well versed in all the sciences and in statecraft. A wise King must always follow the opinion of the members of the Council of Ministers' and from the even older and more venerable Mahabharata from the second century A.D. he finds a verse which states that 'the King must invest only that minister with jurisdiction who has lawfully earned the confidence of the PauraJanapada (roughly the 'Assembly of the Realm') and even finds supporting practices of the detailed official procedures on 'motions', 'voting', and 'resolutions' for instance from the medieval era of Emperor Asoka, which he claims anticipated 'to an astonishing extent the rules of business prevalent in the legislative assemblies today, ${ }^{84}$

During the debates over the office of president there were many debates and proposals on how to condition and constrain the head of state to avoid any possibility of a figure of Curzonian pretensions dominating the political landscape. For instance the Constitutional Adviser recommended the establishment of a Council of State to assist the President in the use of his discretionary powers that were left to convention. Rau makes a note of the need for a 'Council of State' which 'is a kind of Privy Council to aid and advise the President on matters of national importance in decision of which any party bias has to be avoided. The Council of State consists of the Prime Minister, the

\footnotetext{
${ }^{83}$ See Rau, India's Constitution in the Making, pp 303-315

${ }^{84} \mathrm{Rau}$, India's Constitution in the Making, pp 315-319
} 
Deputy Prime Minster, the Chief Justice of the Union, the Speaker of the House of Representatives, the Chairman of the Senate, the Advocate-General, every ex-Prime Minister, every ex-Chief Justice and a limited number of other persons appointed by the President in his absolute discretion. It is a non-party Council of elder statesmen including judges. Such a Council may be found useful in India in such matters as the protection of minorities, the supervision, discretion and control of elections, and the appointment of judges of the Supreme Court and the High Courts'. ${ }^{85}$

These discretionary powers of the Head of State articulated by Rau were unsurprisingly similar to those left to the discretion of the Governor-General under the 1935 Act. The discretionary powers of the President with a formal Council of State to advise him in the employment of such powers struck at the heart of cabinet government in its attempt to create further horizontal accountability within the executive with its supervisory powers and competition with the Council of Ministers. However, the Nehru-chaired Union Constitution Committee (with the support of the Patel chaired Province Constitution Committee) rejected such suggestions of the President having such constitutional discretions as redundant. They also abandoned the need for a Council of State, believing that all the powers vested in the President should be exercised on the advice of his Ministers and not any other Council ${ }^{86}$ that could 'curb the power of Cabinet' as the sole artery of formal advice to the Head of State under whose seal executive power was imposed and thus maintained the 'efficient' Westminster institutional practice of having the Cabinet as the only important body of responsible advisers. ${ }^{87}$

The Drafting Committee of the Constituent Assembly originally advocated an "Instrument of Instructions" for the President, similar to the instructions for the Governor-General under the pervasive 1935 Act. The proposed Republican Instructions went further and delineated on the procedures to appointing the Executive. The President was to be 'guided by the Instructions' and in constituting his Council of Ministers should

\footnotetext{
85 “Confidential - Memorandum on the Union Constitution”, 30 May 1947, B. N. Rau Papers, Nehru Memorial Museum and Library, New Delhi [henceforth NMML]

${ }^{86}$ There were other 'Councils' proposed such as the 'Union Economic Council' to advise the Executive, which was rejected. See "Memorandum on the Union Constitution" in Rau, India's Constitution in the Making, pp 72-73, 86-88

${ }^{87}$ See Shiva Rao, The Framing of India's Constitution - A Study, pp 338-339; "Minutes of the Union Constitution Committee", 9 June 1947 in B. Shiva Rao, The Framing of India's Constitution - Select Documents, Vol. II, Bombay: The Indian Institute of Public Administration, 1968, pp 554-558 and Austin, The Indian Constitution: Cornerstone of a Nation, pp 128-131
} 
appoint a person who has been found by him most likely to command a stable majority in Parliament as the Prime Minister, and then to appoint on the advice of the Prime Minister those persons (including so far as practicable members of important minority communities) who will best be in a position to command the confidence of Parliament.

The President would be supported by an 'Advisory Board' whose membership was to be of not less than fifteen members (including the Leader of the Opposition of any House) to advise on such issues as senior judicial, diplomatic and public service appointments. $^{88}$ Assembly members also wanted the Constitution and further "Instructions" to make clear that the President would always act on the advice on his ministers.

Both sets of "Instructions", though not justiciable or enforceable and beyond the jurisdiction of the courts were later in 1949 thought to be unnecessary. Ambedkar, and the Drafting Committee he chaired, reversed their original position in favour of such written conventions to stand closer to the Nehru-Patel view ${ }^{89}$, the Westminster view, that Cabinet was 'collectively responsible to the House of People, answerable to the House in regard to the budget, all legislation and indeed every matter connected with the administration of the country. There was therefore no necessity for setting out in detail in an article of the Constitution what the functions and incidence of responsible government would be'. And when asked in the Assembly what would happen if the instructions were withdrawn and the President acted against the advice of his ministers, Sir Alladi Krishnaswami Aiyar conclusively answered of behalf of the Drafting Committee that 'if a President stood in the way of the Council of Ministers discharging that responsibility, he would be guilty of violation of the Constitution and would ... be liable for impeachment'. This conventional Westminster view of executive accountability and responsibility was acknowledged and the proposals of having formal

\footnotetext{
88 "Instructions to the President" in B. Shiva Rao, The Framing of India's Constitution - Select Documents,

Vol. IV, pp 84-86

89 ' ...one is forced to deduce that Ambedkar and the members of the Drafting Committee, perhaps under pressure from Nehru or Patel [who were against the need for written instructions]'. In Austin, The Indian Constitution: Cornerstone of a Nation, pp 138-139
} 
executive advice from statutory bodies in addition to the Council of Ministers and the idea of Instructions for President were quickly spurned. ${ }^{90}$

As one would expect with such advocacy of analogous forms of Westminster, Rau was swift to negate the idea of village democracy or panchayat plan as it would be 'impracticable to endow them... with specific administrative or legislative or judicial function' for the new Indian democracy and its constitution. ${ }^{91}$ Despite being the protagonist of swaraj that hastened the end of British rule, Gandhi's alternative ideas for democracy did not manifest itself after independence. Regardless of the popular consciousness generated by India's "tryst with destiny" the "Gandhian dreams of selfsustained village reconstruction' were not realised. ${ }^{92}$ In fact the Constituent Assembly endorsed their Constitutional Adviser's aversion to Gandhi's radical ideas and 'at no time, significantly, did the Constituent Assembly ever consider instituting Gandhianstyled non-party government, with a weak centre and power diffused among selfgoverning villages'. ${ }^{93}$ Instead the strong traditions in British India of a powerful centre and Westminster parliamentary government were adopted with careful consideration by an Indian manned Constituent Assembly.

As will be discussed in a following chapter, the Constituent Assembly's deliberation was naturally conditioned by the violence and fear surrounding Partition as well as the assassination of their moral leader Gandhi and numerous other threats to the stability of the young nation. ${ }^{94}$ India's decisions and circumstances were unprecedented. Similar constitutional conventions had occurred in Canada and Australia, which created with localised participation and vagaries a constitutional structure based consciously on the Westminster parliamentary system, but, like India, with crucial federal adaptations. India's elite had observed such self-determination in the transplanted settler colonies with interest. However, India had crucial differences. In addition to the vital social and demographic contrasts and the absolute antitheses that India's freedom struggle and its liberating catharsis provided, against the loyalist constitutional gradualism of settler

\footnotetext{
${ }^{90}$ Cited in Shiva Rao, The Framing of India's Constitution - A Study, pp 379-380

${ }^{91}$ Letter from Rau to Dr Rajendra Prasad, President of the Constituent Assembly in Rau, India's Constitution in the Making, pp 331-333

${ }^{92}$ Sugata Bose and Ayesha Jalal, Modern South Asia - History, Culture, Political Economy, New York: Routledge, 1998, p 197

${ }^{93}$ Barbara D. Metcalf and Thomas R. Metcalf, A Concise History of India, Cambridge: Cambridge University Press, 2002, p 228

${ }^{94}$ Austin, The Indian Constitution: Cornerstone of a Nation, pp 44-45 and Henry C. Hart, "The Indian Constitution: Political Development and Decay”, Asian Survey, Vol. 20, No. 4, April 1980, p 438
} 
colonies, India also made outward and symbolic constitutional changes to reject the 'dignified' aspects of British Westminster culture.

Unlike Canada and Australia, which never had any intention during that period of constitutional self-formulation of becoming republics or breaking from Westminster, India had decreed as such with immediacy. At the very first session of the Constituent Assembly Nehru moved an Objectives Resolution. Nehru's resolution declared many key principles including un-Westminster constitutional platitudes that 'secured to all the people of India justice, social, economic and political; equality of status, of opportunity, and before the law; freedom of thought, expression, belief, faith, worship, vocation, association and action, subject to law and public morality' and 'adequate safeguards' for minorities and 'depressed and backward' classes and tribal groups'. As well as other such pronouncements the resolution's momentous and constitutionally definitive point was:

This Constituent Assembly declares its firm and solemn resolve to proclaim India an Independent Sovereign Republic...wherein all power and authority of Sovereign Independent India its constituent parts and organs of government, are derived from the people... ${ }^{95}$

Nehru's resolution was not only adopted unanimously but its sentiments later became the basis for the Preamble of the Constitution of the Republic of India. Therefore in contrast to London, Ottawa, Canberra, Wellington or closer to home in Colombo, Delhi noticeably rejected the 'dignified' monarchical feature of British culture. India for its adapted Westminster wanted the Bagehotian 'efficient' operating culture of the British constitution and not the 'dignified' and ceremonial aspects that were attached to the monarchy and colonial rule. ${ }^{96}$ Denying the British King's sovereignty over India, the Constituent Assembly instead looked to Paris for constitutional comparison where Nehru's mind could not help but go 'back to that mighty revolution which took place over 150 years ago and to that Constituent Assembly' that had met in comparable

\footnotetext{
${ }^{95}$ Objectives Resolution in Shiva Rao, The Framing of India's Constitution - A Study, pp 121-122

${ }^{96}$ The Indians, like the Pakistanis, also refused Lord Mountbatten's plea that the Union Jack be placed in the upper canton of their new flags. See Viceroy's Personal Report No. 13, 18 July 1947 in

Constitutional Relations Between Britain and India - The Transfer of Power 1942-7, Vol. XII, Nicholas Mansergh (ed.), London: Her Majesty's Stationary Office, 1970-83, pp 230-231
} 
radical circumstances'. ${ }^{97}$ India wished to become a republic within the Commonwealth, long before the idea became de rigueur and in the process shocked stalwart Dominions like Australia, New Zealand and even Ceylon and Pakistan. ${ }^{98}$ India wanted the legitimacy and clarity of sovereignty that Republican status sanctioned and which its people demanded - but at the same time India had a craving and institutional inclination for the parliamentary executive of the British type, which existed with individual mutations from Cape Town to Canberra. British practice had the crown intrinsically linked to the system and this was replicated in theory across the Dominions. Now with 'brazen assertion' India wanted the system but not the crown. ${ }^{99}$

Rau once again deftly delved into India's ancient past to find an example of ancient Gupta Empire under Chandra Gupta I being in alliance with the republic of the Liccavis as 'an instance of a republic in partnership with an empire' to advocate both the retention of Commonwealth membership for India and the beneficial amenability of the Westminster institutional practices. ${ }^{100}$ India utilised its brief interregnum of Dominionhood in 1947-50 to formulate what was at the time a constitutional dichotomy. India was 'rejecting the imperial vice-regal style of government associated with the Raj' but 'nevertheless sought inspiration in domestic British political practice'. ${ }^{101}$ India may have been taking unprecedented action in having a President as head of state, rather than a Governor-General but even though it was symbolically different, the Indian leaders in reality wanted their head of state to act like a traditional New Westminster Governor-General with a mere change in 'dignified' nomenclature. As in other areas of constitutional government, the Indian elite accepted the Westminster 'efficient' institutions and operating culture - perhaps even unconsciously. Whatever else it was convincing enough for Eden to state on watching the Lok Sabha

\footnotetext{
${ }^{97}$ Nehru's speech to the Constituent Assembly, 13 December 1946, Cited in Subhash C. Kashyap, Jawaharlal Nehru and the Constitution, New Delhi: Metropolitan, 1982, p 78. The French 1789 Revolution held special importance in Nehru's thoughts. On Bastille Day in 1940 after France had recently fallen to the Germans Nehru emotionally wrote: 'my thoughts go back a hundred and fifty years and survey the exciting course of French history, since the day that France became the mother of freedom. I have loved that France even in her decay and imagined that, whatever might befall her, her immortal spirit would survive and triumph.' Nehru, “Quatorze Juillet”, 16 July 1940, in The Essential Writings of Jawaharlal Nehru, Vol. 2, pp 220-221

${ }^{98}$ For a discussion of the issues of India becoming a Republic within the Commonwealth and the reactions of the Dominions see Harshan Kumarasingham, “The 'New Commonwealth' 1947-49: A New Zealand Perspective on India Joining the Commonwealth", The Round Table, Vol. 95, No. 385, July 2006, pp 441-454 and Frank Bongiorno, "Commonwealthmen and Republicans: Dr H.V. Evatt, the Monarchy and India”, Australian Journal of Politics and History, Vol. 46, No. 1, pp 33-50

${ }^{99}$ Kumarasingham, “The 'New Commonwealth' 1947-49: A New Zealand Perspective on India Joining the Commonwealth", p 441

${ }^{100}$ Rau, India's Constitution in the Making, p 348 and p 356

${ }^{101}$ Metcalf and Metcalf, A Concise History of India, p 227
} 
that 'he felt more at home during his witnessing of it [the Indian Parliament] than he has while attending that of the Australian parliament' ${ }^{102}$

Most members of the Constituent Assembly recognised, as Rau argued, that the type and form of the executive was 'the most important question in the framing of the constitution'. ${ }^{103}$ India's acculturated Constituent Assembly had resolved with relative alacrity the preference of having an adapted Westminster parliamentary system - with the substance and not the symbols; the Bagehotian 'efficient' without the 'dignified'. They desperately desired to move out from the shadow of imperialism and consequently and naturally wanted to symbolically be a republic to project their independence and self-determination. Unlike the United Kingdom and the Dominions across the seas India's constitution makers were keen to articulate and stipulate the powers and roles of the executive to allay the fears of any new Indian viceroyalty or indigenous imperialism arising from the ashes of empire. And yet the constitution makers also realised that considerable power would be required for the executive to maintain and govern the chaotic continent of India and its multifarious manifestations within its borders. Strong and accountable government was desired. Brass argues that this created 'a basic tension in the post-Independence political order, arising in part out of features of the Indian Constitution itself, between authoritarian and democratic tendencies'. ${ }^{104}$

India's constitutional framers wanted accountable government but with executive flexibility, that is intrinsic within the Westminster system and its executive culture. The debates surrounding the offices and powers of the President, Prime Minister and the Council of Ministers specifically will be discussed and analysed in greater detail in the following chapter, but it is worth examining here some of the issues that were voiced concerning different forms of the executive that led to the acceptance of parliamentary executive heavily drawn from Westminster practice. Rau's questionnaire, which was later sent to the powerful Union Constitution Committee (chaired by Nehru) in early 1947 had included not only Westminster executive practice, but also furnished the reader with contrasting executive examples from countries such as Switzerland and the United States of America. The questionnaire ${ }^{105}$ included queries and questions concerning the nature of the executive, the selection and responsibilities of the

\footnotetext{
${ }^{102}$ Cited in W. H. Morris-Jones, The Government and Politics of India, $2^{\text {nd }}$ edition, London: Hutchinson University Library, 1967, p 197

${ }^{103} \mathrm{Rau}$, India's Constitution in the Making, p 22

${ }^{104}$ Brass, The Politics of India since Independence, p 35

105 "The Questionnaire" in Rau, India's Constitution in the Making, pp 16-41
} 
executive and also the relationship between the head of state and ministers, which he later expanded to compose a 'Memorandum on the Union Constitution'106 and 'Draft Clauses on the Union Constitution'. ${ }^{107}$ Rau, as has been seen above, argued in favour of cabinet government with a constitutional head of state. In June 1947 the Union Constitution Committee in a joint meeting with the Provincial Constitution Committee (with Patel as chairman) endorsed the decision that India should have 'the parliamentary system of constitution, the British type of constitution, with which we are familiar' showing cultural inclination for Westminster institutions. ${ }^{108}$ A tiny portion of Assembly members did bring up alternative suggestions to have a fixed-term proportionally elected executive removable only by impeachment as in Switzerland and an even smaller number favoured the American presidential system, but these proposals never carried. ${ }^{109}$

India's elite representatives at this constitutional high table wanted a form of parliamentary cabinet government that was responsible to the legislature, drawn from the legislature and held a majority and thus the confidence of the legislature and as such conditioned by Westminster cultural attitudes and values. In a process of conscious adoption and implantation, India's constitution incorporated some two hundred articles of the Government of India Act of 1935. ${ }^{110}$ The Constituent Assembly chose Westminster style accountability over the stability theorised from the American and Swiss models. This was not as a great a decision as it implies since the Congress Party's indisputable dominance gave the Congress Governments easy numerical stability in Parliament that lasted well into the 1970s. In answering criticisms in his capacity as chairman of the Union Constitution Committee on alternative forms of executive Nehru stated it raised 'a very fundamental issue of what form you are going to give to your Constitution, the ministerial parliamentary type or the American type. So far we have been proceeding with the building up of the Constitution in the ministerial sense and ... we cannot go back upon it'. ${ }^{111}$

\footnotetext{
106 "Memorandum on the Union Constitution" in Rau, India's Constitution in the Making, pp 62-97

107 "Draft Clauses of the Union Constitution" in Rau, India's Constitution in the Making, pp 97-141

108 "Minutes of the Union Constitution Committee", 9 June 1947 in B. Shiva Rao, The Framing of India's Constitution - Select Documents, Vol. II, pp 556-557 and Austin, The Indian Constitution: Cornerstone of a Nation, p 120

${ }^{109}$ See Austin, The Indian Constitution, pp 118-124 and Shiva Rao, The Framing of India's Constitution, pp 339-340

${ }^{110}$ Metcalf and Metcalf, A Concise History of India, pp 227-228

${ }^{111}$ Cited in Shiva Rao, The Framing of India's Constitution - A Study, pp 340
} 
The crucial step now was to shape and address the powers of the executive actors under a parliamentary cabinet system that had only been functioning for a short while during the dying days of British rule. The renowned constitutional expert Dr B. R. Ambedkar, Chairman of the Drafting Committee, expressed what he envisaged would be the general character of the Executive when he presented the Draft Constitution to the Assembly on 4 November 1948:

In the Draft Constitution there is placed at the head of the Indian Union a functionary who is called the President of the Union. The title reminds one of the President of the United States. But beyond identity of names there is nothing in common between the form of government prevalent in America and the form of government proposed under the Draft Constitution. The American form of government is called the Presidential system of government. What the Draft Constitution proposes is the Parliamentary system. The two are fundamentally different. Under the Presidential system of America, the President is the chief head of the executive... Under the Draft Constitution the President occupies the same position as the King under the English Constitution. He is the head of the State but not of the executive. He represents the nation but does not rule the nation. He is the symbol of the nation. His place in the administration is that of a ceremonial device on a seal by which the nation's decisions are made known... 112

This forecast would be tested very soon on the powers and responsibilities of the President and his ministers, particularly the Prime Minister, which would shape the polity and test the mettle of this 'infant democracy'. ${ }^{113}$ Ambedkar argued that the Draft Constitution 'in recommending the Parliamentary system of executive has preferred more responsibility to more stability'. ${ }^{114}$ India demanded a strong executive, one that was horizontally accountable daily in Parliament, but would this be a silent clause more honoured in theory rather than in practice as in the British fashion? India would be shaped by the personalities and actions of its early senior constitutional actors that held

\footnotetext{
${ }^{112}$ Cited in Shiva Rao, The Framing of India's Constitution - A Study, pp 341-342

113 The constitutional lawyer Sir Alladi Krishnaswami Aiyar stated in the Assembly that 'an infant democracy cannot afford, under modern conditions, to take the risk of a perpetual cleavage, feud, or conflict or threatened conflict between the Legislature and the Executive' - cited in Austin, The Indian Constitution: Cornerstone of a Nation, p 123

${ }^{114}$ Shiva Rao, The Framing of India's Constitution - A Study, p 342
} 
and wrought the great offices of state defining and sometimes blurring the perimeters of executive horizontal accountability. 


\section{The Indian Version of First Among Equals}

Just ten years before India attained independence Nehru anonymously penned an article under the pseudonym Chanakya: a fascinating self portrayal in a national publication entitled Rashtrapati. ${ }^{115}$ "Chanakya" waxed eloquently on the power of Nehru as he was rapidly gaining both popularity across the country and ascendancy in the Congress and as such 'he is bound up with the present in India, and probably the future, and he has the power in him to do great good or great injury'. ${ }^{116}$ The danger was that Nehru could take advantage of his powers 'sweeping aside the paraphernalia of a slow-moving democracy' since he 'has all the makings of a dictator in him - vast popularity, a strong will directed a well-defined purpose, energy, pride, organisational capacity, ability, hardness, and, with all his love of the crowd, an intolerance of others and a certain contempt for the weak and the inefficient ... In normal times he would be just an efficient and successful executive, but in this revolutionary epoch, Caesarism is always at the door, and is it not possible that Jawaharlal might fancy himself as a Caesar. Therein lies danger for Jawaharlal and for India' ${ }^{117}$

This prediction of centralised abusive executive power by a Prime Minister should have been more considered in the debates over India's constitution and political system, which instead focussed on the executive as a whole. India was acculturated to the Westminster operating cult of flexibility in order to deal with its pressing institutional and social context, but this may have blinded the political elite from giving more attention and detail as to the relations and horizontal accountability of the President, Prime Minister and Cabinet. This crucial intra-executive relationship was generally left to ambiguity, which the flexibility entailed, and as shall be seen in these early years often led to confusion and conflict. India's Constituent Assembly had resolved to have a parliamentary system largely fashioned by Westminster practices. The constitution established a parliament comprising two houses. The upper house, the Rajya Sabha (the Council of States) has a maximum membership of 250 of which, except for a maximum of twelve nominated members by the President, are elected by the various State

\footnotetext{
${ }^{115}$ Nehru latter explained that Rashtrapati is Sanskrit for Head of State while Chanakya was a famous Minister of Chandragupta, who built an empire in North India in the $4^{\text {th }}$ century BC and was "the prototype of Machiavelli". The article was published in The Modern Review of Calcutta in November 1947.

116 "Rashtrapati”, October-November 1937, The Essential Writings of Jawaharlal Nehru, Vol. 2, p 644

117 "Rashtrapati", pp 644-645
} 
Legislative Assemblies. This indirectly elected house is subordinate in power and substance to the Lok Sabha (House of the People). The lower house has a membership of not more than 520 and is elected, in the traditional manner of Westminster systems, from country-wide electorates, won by a simple plurality by an adult franchise of all citizens over twenty-one. Parliament was to have immense powers and act as the great forum of the nation. Its first Speaker, G.V. Mavalanka, wanted Parliament to be an independent institution not to be seen as an extension of government or of party. Nehru held this view as well and made considerable efforts to support the fiction of having an alternative ministry within the Opposition in parliament. None of this, however, could hide the ultimate power of the central executive of which prime ministerial dominance was one of the central motifs. ${ }^{118}$

For all the theoretical and philosophical polemics that pealed through the Assembly chambers the debates were just political and constitutional conjecture, and, though well argued, needed to be tried to be truly tested. The high and erudite exhortations could only mean so much. The executive was naturally the greatest concern as Nehru's Chanakya prophesised. The great offices of Governor-General (President from 1950) and Prime Minister naturally aroused the greatest anxiety and interest. The very unique circumstances of India in every sense meant that there was an almost incomparable feeling of uncertainty. The first years would be fundamental for the Indian Union. The roles, powers and interactions of the Head of State and Head of Government would shape the Indian polity - though with the bloody and chaotic birth of India in 1947 abetted by an anarchic colossal plurality of every variety nothing could be said with certainty. The executive, naturally, had the power to mould India's political future.

The almost disregarded period of India's Dominionhood 1947-1950 was, even without the mighty deliberations of the Constituent Assembly, a period of fundamental impact for India's political institutions and the executive ones in particular. This phase of well under three years demanded from the executive an appraisal of responsibilities, which was now totally theirs to define since India was now free of direct English tutelage; no more demonstrative cries to London's India Office or the Viceroy's Palace, instead the electorate of India became with suddenness the mercurial arbiter of political fortune. However, the largest electorate in the world still could not decide everything. In fact not until 1952, when the first general election after independence was held, would

${ }^{118}$ Austin, Working a Democratic Constitution, pp 658-661 
India's mega masses be able to exercise their unique powers. Until then the great mechanics and machinations of state lay in the hands of an infinitesimal proportion of the population. With such disproportional powers this cluster of notables needed to establish their executive power from the ashes of Empire.

The demarcations of executive power were keenly fought out in the first ten, and especially five, years of independence. This executive struggle and search for constitutional pre-eminence was unquestionably the preserve of the executive players conducted without the involvement or open knowledge of the electorate. In India one of the lesser known, but nonetheless essential executive battles, which would establish the prominence of prime ministerial power, was the very real constitutional mêlée between Nehru as Prime Minister and the Heads of State, especially with the first president Dr Rajendra Prasad. Though it is tempting in hindsight to see independent India as Nehru's India, his dominance was not always in evidence, especially during the early when various political figures existed to exercise degrees of horizontal accountability. However, in the end he would solely emerge as the premier and unchallengeable agent of executive power.

\section{Prime Minister and Cabinet}

Even with its directives, principles and extravagant length, the Indian Republic's Constitution still relied on conventions and personalities and thus operated very much in the Westminster way. As Alexandrowicz explains, despite the Constitution's written nature and record length 'Parliamentary and Cabinet government in India in its entirety is inconceivable without conventional rules outside the body of the Constitution'. ${ }^{119}$ The most imperative convention in the British system was the Bagehotian buckle of Cabinet fastening the executive with the legislature. In India, unlike Britain and the settler Dominions, the Prime Minister and Cabinet were overtly mentioned in constitutional articles. However, in spite of this there was still a very real constitutional ambiguity over the powers of Cabinet. India as the first colony in Asia or Africa to gain independence had set a precedent without having a precedent. ${ }^{120}$ The man more than any other who characterised and moulded independent India was Jawaharlal Nehru, as Prime Minister for the first seventeen years of independence. The executive could not

\footnotetext{
${ }^{119}$ C. H. Alexandrowicz, Constitutional Developments in India, Bombay: Oxford University Press, 1957, p 140

${ }^{120}$ Though other colonies were close behind such as Pakistan, Burma and Ceylon.
} 
help but bear his indelible imprimatur. Nehru was the central, though not until late 1950 the undisputed, leader of India. The formal powers endowed on the Prime Minister by the Constitution as distinct from Cabinet do not accurately describe his powers and influence. As Brown expresses:

Nehru, by virtue of his energy and ability, and his huge public repute within and beyond the Congress Party, used the potential available to him, dominating the Cabinet and the Lok Sabha. Of course he had no predecessors on whom to model himself, and no precedents from within the Indian political system and to an extent made his own job. Given his commitment to economic reform and his role in the new Planning Commission, his control over foreign affairs by virtue of being his own Minister of External Relations, and his sense of vocation to make profound changes in India, he worked like a human dynamo, and little in government escaped his notice and concern. ${ }^{121}$

Therefore any examination of the executive during the first ten years after independence is inescapably entwined with the unique Nehru, who becomes naturally the focus on any analysis thereof.

\section{The Last Englishman to Rule India - Prime Ministerial Powers under Nehru}

Nehru in the autumn of his long years as Prime Minister, remarked to the economist Professor J. K. Galbraith, then serving as President Kennedy's Ambassador to India, that he was the last Englishman to rule over India. ${ }^{122}$ His latest biographer in a recent article depicts the Trinity College, Cambridge man as 'one of the last great Victorians in the British Empire' and like Gandhi, an "Outsider" operating inside Indian politics. ${ }^{123}$ The reasoning behind Nehru's own admission and numerous historians latching on to his affinity with England was only partly social and seldom cosmetic deep. In fact, unlike Jinnah in his Savile Row suits, Nehru was quick to dispense with any outward sartorial sycophancy of British culture, preferring Indian dress very early in his political career. Intellectually, however, he gleefully drew upon Western thought and reminisced in his autobiography how he was pleasantly imbued at Cambridge with the cerebral cult

\footnotetext{
${ }^{121}$ Brown, Nehru - A Political Life, pp 205-206

${ }^{122}$ Cited in Sarvepalli Gopal, "Nehru and the Commonwealth" in Retreat from Power - Studies in Britain's Foreign Policy of the Twentieth Century, Vol. 2, David Dilks (ed.), London: Macmillan, 1981, p 150

${ }^{123}$ Judith Brown, “Jawaharlal Nehru and the British Empire: The Making of an 'Outsider' in Indian Politics”, South Asia: Journal of South Asian Studies, Vol. XXIX, No. 1, April 2006, pp 69-75
} 
of Cyrenaicism. ${ }^{124}$ Nehru's intimacy with figures such Albert Einstein, Bertrand Russell, Harold Laski and after independence even Sir Winston Churchill ${ }^{125}$ enhanced his reputation for being thoroughly at home with Western thought and practices.

Occidental theories on government - especially parliamentary government - would be no exception, not unnaturally for a man who as a young Indian schoolboy in London, could, unlike any of his privileged English classmates, name the entire 1905 Cabinet of Sir Henry Campbell-Bannerman, which incidentally contained Churchill, an old Harrovian like Nehru, who had become Under-Secretary at the Colonial Office. ${ }^{126}$ In fact like many members of the British Establishment with whom he fraternised in their drawing rooms Nehru felt 'uneasy' about America and in turn Americans believed 'he was disposed to be somewhat contemptuous of them and the relative newness of their history and culture ${ }^{127}$, which may explain why he gained little inspiration from that most famous Republic when creating the institutions for his own one. Though Nehru's rhetoric under British rule was stridently anti-colonial he was later as Prime Minister, imbued, instilled and impressed with Westminster institutions, albeit with necessary changes. As W. H. Morris-Jones explains:

Since history abounds in paradox, it should not be unexpected that the postimperial state is at once a reflection of and a reaction against the preceding imperial state. The founding fathers, who then normally became the first rulers, of new successor states sought both to bring down and re-build, both to replace and to reproduce. The past regime was anathema but at the same time a model worthy in some respects of preservation or imitation. The rulers certainly were to be changed but the rules of ruling might be carried over. ${ }^{128}$

Nehru, whether by boycott or being a guest at His Majesty's Prisons, had avoided major experience, like most of the Congress hierarchy, of administrative governance. Even

\footnotetext{
${ }^{124}$ Jawaharlal Nehru, An Autobiography, London: John Lane the Bodley Head, 1936, pp 19-21

${ }^{125}$ Churchill, back in office in 1951, later called Nehru "The Light of Asia". See Martin Gilbert, Winston

S. Churchill, Never Despair, 1945-65, Vol. VIII, London: William Heinemann, 1988, p 1094. For an examination of Churchill's complex relationship with India see Sarvepalli Gopal, "Churchill and India" in Churchill - A Major New Assessment of His Life in Peace and War, R. Blake and Wm. Roger Louis (eds.) London: Oxford, 1993, pp 457-472

${ }^{126}$ Nehru, An Autobiography, p 17

${ }^{127}$ Brown, "Jawaharlal Nehru and the British Empire: The Making of an 'Outsider' in Indian Politics", pp $72-75$

${ }^{128}$ W. H. Morris-Jones, "Shaping the Post-Imperial State: Nehru's letters to Chief Ministers" in Imperialism, the State and the Third World, Mark Twaddle (ed.), London: British Academic Press, 1992, p 220
} 
the interim government, which was formed in the run up to 1947, was constitutionally merely a refashioned Viceroy's Executive Council. Nehru, who by fortunate virtue of being Congress President at the time on the insistence of Gandhi ${ }^{129}$, was invited by the Viceroy, Lord Wavell, to become Vice-President of the Council which meant he was a de facto acculturated Prime Minister, though the Council was still formally presided over by the Viceroy. Though responsible to the Viceroy and serving as individual members on the Council the members decided to act on issues collectively like a Cabinet. Wavell himself agreed regardless of the legal position or previous practice to 'let the Interim Government function in accordance with the conventions of cabinet government as practiced at Westminster and in independent Dominions like Australia and Canada' ${ }^{130}$ though he did not agree to the Congress 'unilateral' demand that he put the Viceroy's extraordinary powers in abeyance and become, in his words, a 'complete cipher'. ${ }^{131}$ With the departure of Jinnah's appointees on the Council and later Partition itself, Nehru left with greater freedom to act and function effectively as a Westminster Head of Government. ${ }^{132}$ The de facto Prime Minister was unanimously elected leader of the Congress Parliamentary Party and became de jure Prime Minister in August 1947.

As in the British system, which India draws natural comparison with; the Prime Minister has peculiar and exceptional powers. By virtue of commanding the confidence of the lower house, the Prime Minister has immense powers and as in Britain this is especially so over patronage from the Cabinet down. The Indian Prime Minister's powers are arguably greater, since along with traditional judicial and public service appointments the Prime Minister is able, with the Head of State's sanction, to appoint the Governors of States and due to Congress hegemony the Prime Minister also has direct influence on the selection of the Chief Ministers of States and their Cabinets. ${ }^{133}$ One of the variances between British Westminster and the Indian Westminster is that

\footnotetext{
${ }^{129}$ Nehru had become Congress President at Gandhi's insistence, despite many in the Congress Working Committee favouring Sardar Patel, which potentially could have meant Patel could have become VicePresident and de facto Prime Minister. See S. C. Gangal, Prime Minister and the Cabinet in India $-A$ Political Study, New Delhi: Navachetna Prakashan, 1972, pp 19-20 and section below for more information on the crucial Nehru-Patel relationship.

${ }^{130}$ Gangal, Prime Minister and the Cabinet in India, p 13

${ }^{131}$ Lord Wavell, The Viceroy's Journal, Sir Penderel Moon (ed.), London: Oxford University Press, 1973 , pp 322-323

${ }^{132}$ For a more detailed analysis of this period of the Interim Government and the Muslim League's involvement see "Provisional Prime Minister 1946-47" in Stanley Wolpert, Nehru - A Tryst of Destiny, New York: Oxford University Press, 1996, pp 369-384

${ }^{133}$ R. J. Venkateswaran, Cabinet Government in India, London: George Allen \& Unwin, 1967, pp 52-53
} 
the Indian Prime Minister draws power directly by office from the Constitution rather than wholly by convention. Article 75 of the Indian Constitution concerns the Prime Minister and Cabinet. The Prime Minister's appointment and in turn the selection of Ministers are stipulated with the clause that 'The Prime Minister shall be appointed by the President and other Ministers shall be appointed by the President on the advice of the Prime Minister'. Thus though Ministers are effectively appointed by the Prime Minister, the prevalent Westminster prerogative of the Head of State's formal discretion over the Prime Minister's own appointment was retained. Though this is qualified with the emphasis on the prevailing Westminster convention of appointing a Prime Minister who commands the confidence of the elected lower House, which is fairly clearly enunciated in the same Article, stating that the 'The Council of Ministers shall be collectively responsible to the House of People', which also lends stress on the Westminster principle of cabinet collective responsibility. ${ }^{134}$

However, there was unquestionably ample vagueness and imprecision to show the necessity of following the conventions of cabinet government as practiced at Westminster and the Dominions or New Westminsters when India's Constitution was intentionally silent on such matters of executive governance and power. As was discussed above in the first chapter, the framers of the Indian Constitution in the Constituent Assembly reserved elements of abstraction in part to keep flexibility to deal with the unknown that India fresh from Partition and its plethoric internal problems faced and also because this was the way it worked in Westminster and where the leaders of the Assembly 'looked for inspiration and guidance'. ${ }^{135}$ The first ten years would demonstrate the difficulties and dilemma of that intentional graft of Westminster executive operating culture.

However, with Nehru at the helm, India had in its first Prime Minister a man who strived to create and recreate his Westminster legacy. Nehru's attitude to his Imperial inheritance was crucial since his 'was not a blind imitation, but a nuanced response' accommodating institutions with 'Weberian rationality'. ${ }^{136}$ As Brown argues, Nehru was 'fashioned out of the urgent realities of India's political experience' and may have said like another iconic figure in history, Martin Luther, "Here I stand. I can do no

\footnotetext{
${ }^{134}$ Articles 75 (1) (3) in Basu, Constitutional Law of India, p 154

135 Venkateswaran, Cabinet Government in India, p 23

${ }^{136}$ Bidyut Chakrabarty, "Jawaharlal Nehru and the Administrative Reconstruction in India: A Mere Imitation of the Past or a Creative Initiative?", South Asia: Journal of South Asian Studies, Vol. XXIX, No. 1, April 2006, p 85
} 
other". ${ }^{137}$ Morris-Jones describes him as a 'preacher-teacher' who by virtue of his unprecedented position socially and politically was able to articulate and formulate India's institutions of state. ${ }^{138}$

Nehru, by the 1952 general election, held undisputed domination of Congress across the country and within Parliament. As Weiner comments, Nehru's strength was that 'he was a far more popular leader in the country' than anyone including Patel despite the Deputy Prime Minister's control over the party organisation. ${ }^{139}$ Nehru had to wait for Patel's death in 1950 to complete his command of Congress and intensify the lack of horizontal accountability on his power. Patel had assisted, with support from other Hindu traditionalists, with the Congress High Command, the narrow election of his ally Purushottam Das Tandon to the Congress Presidency. Tandon shared Patel's Hindu chauvinistic views and Nehru very quickly voiced his displeasure of his assumption of the presidency of someone he considered anti-secularist. ${ }^{140}$ Nehru was openly dismayed with Tandon, but with Patel alive he could not easily displace him. The victor of 1951 election to the Congress Presidency would have a powerful position as the country would be entering its first General Election within months of the Party vote. With Patel dead Nehru allowed himself to be nominated for the post to assert his political position and by not giving way and threatening his own resignation impelled the incumbent to resign as President. The All India Congress Committee resoundingly elected the Prime Minister to replace Tandon. ${ }^{141}$

Nehru did what he claimed he never wanted to do - hold the Prime Ministership and Congress Presidency, which he held for three years before handing over to a malleable successor who in turn was succeeded by Indira Gandhi, his daughter and heir to the Nehru legacy. Nehru thus ensured to Congress that his imprimatur was acknowledged, his indispensability assured and the indisputability of his ascendance over the Party organisation at the forthcoming elections. ${ }^{142}$ Nehru never had serious problems with the

\footnotetext{
${ }^{137}$ Brown, Nehru - A Political Life, p 340

${ }^{138}$ Morris-Jones, "Shaping the Post-Imperial State: Nehru's letters to chief ministers", p 225

${ }^{139}$ Myron Weiner, Party Building in A New Nation - The Indian National Congress, Chicago: University of Chicago Press, 1967, pp 38-43

${ }^{140}$ B. D. Graham, "The Prime Minister and the Hindu Right" in Nehru to the Nineties - The Changing Office of Prime Minister in India, James Manor (ed.), New Delhi: Viking, 1994, pp 187-188

${ }^{141}$ For greater detail on Nehru's battle with Tandon see "The Road to Elections" in Sarvepalli Gopal, Jawaharlal Nehru - A Biography, Volume Two: 1947-1956, London: Jonathan Cape, 1979, pp 149-165

${ }^{142}$ Graham, "The Prime Minister and the Hindu Right", pp 189-190; Robin Jeffrey, "The Prime Minister and the Ruling Party" in Nehru to the Nineties - The Changing Office of Prime Minister in India, pp 166167; Michael Brecher, Nehru - A Political Biography, Abridged edition, London: Oxford University
} 
Party ever again in the ten years covered and even after 1957 the most serious example of discord was much later when he faced his first ever no-confidence motion after the debacle over the China war in August 1963. The motion was easily defeated and anyway as all acknowledged there was never any serious threat to Nehru as Prime Minister or Congress supremo at any time after Patel's death since as Brown argues 'it was unthinkable that any other Congressmen would challenge him'. The three General Elections during his seventeen years office - 1952, 1957 and 1962 - were effectively mandates in Nehru, who for example was so highly involved that he was personally involved in the selection and vetting of over 4000 candidates for the 1952 General Election. Congress under his leadership secured massive majorities in these elections in the Lok Sabha of over seventy per cent and close to fifty per cent of the popular vote. ${ }^{143}$ His power over the Party and popularity in the country was a reminder to any rivals within the executive of his secure position.

It was only natural that Nehru and his relationships with institutions and political actors would dominate and permeate the first ten years of Independence. The Cabinet would not and could not escape his omnipresence. A study of Cabinet is primarily a study of Nehru who had social, party and institutional power. Cabinet commanded no effective form of horizontal accountability post 1950. Nehru, as well as being Prime Minister, also took on the portfolio of External Affairs and made it his exclusive domain. Interestingly, given India's economic problems and Nehru personal interest in socialism, the Prime Minister also chaired the powerful Planning Commission set up in May 1950 as a body to advise on economic planning and development and had a small membership of initially six from private, political and public fields. Such was the influence of this body which Nehru dominated that it excited the executive institutional jealousy of other organs of government. In fact it caused the resignation of the first Finance Minister of India, the non-Congressman, John Mathai, one of the few independent voices in the Cabinet, just a month after its establishment due to the fact that he was merely an ordinary member despite being responsible for financial matters to the Union Cabinet and saw the contentious Commission as a threat to the Cabinet's position and his within it. Mathai and others worried that it was becoming a 'Super-

Press, 1961 p 166; Brown, Nehru - A Political Life, pp 194-195 and see Nehru to Purushottam Das Tandon, 8 August 1950 in C. Rajagopalachari Papers, NMML.

${ }^{143}$ Jeffrey, "The Prime Minister and the Ruling Party", p 166 and Brown, Nehru - A Political Life, pp 198, 286 and 331 
Cabinet' in regard to economic affairs. ${ }^{144}$ In his June 1950 resignation statement Mathai complained that 'Cabinet responsibility has definitely weakened since the establishment of the Planning Commission' with the Members being treated like Cabinet Ministers and by 'having the Prime Minister presiding over such a body, it is difficult to resist the Planning Commission developing into a parallel authority of equal standing with the Cabinet', which he firmly and naturally opposed. ${ }^{145}$

Nehru survived Mathai's departure with ease and was thus able to effectively dominate economic and foreign affairs during his long years as Prime Minister with unprecedented institutional power for a New Westminster leader and showed that not even a finance minister had real horizontal accountability on him. Cabinet looked to Nehru for absolute leadership and direction. In fact the Prime Minister, being a pedant for democratic procedure, found this hard to balance against his impatient vision and understanding of what he wanted for India. With Cabinet, the apex of executive authority in Westminster systems, Nehru had to

curb his inclination to take all decisions and make out that they were the results of innumerable discussions. He had to disown the eagerness of his colleagues to leave all making of policy to him and insist on the Cabinet seeming to function as a reality ... But he himself found it no easy matter to function as merely the leader of a team ... the Cabinet was gradually reduced to a collection of tame subordinates ... In the framework of democratic institutions that Nehru strove to install in India, the weakest link was Cabinet government. He insisted that all important matters should at some stage be brought up in Cabinet; there were numerous Cabinet committees and consultation was frequent; the deficiency was in spirit and animation. But at least the procedures of collective policymaking were established, for life to be later instilled in them. This was the work of Nehru, achieved against the drive of his own personality and despite the eager subservience of mouldering mediocrities who claimed to be his colleagues. ${ }^{146}$

In the Indian context, using O'Donnell's model, Cabinet had delegated its powers to the Indian Prime Minister. Power was the Prime Minister's culturally and institutionally. The death of Gandhi and Patel in the early years ended the triumvirate and India became

\footnotetext{
${ }^{144}$ Venkateswaran, Cabinet Government in India, pp 109-121

${ }^{145}$ Cited in Venkateswaran, Cabinet Government in India, pp 76-77

${ }^{146}$ Gopal, Jawaharlal Nehru - A Biography, Volume Two: 1947-1956, p 303
} 
from the end of 1950 a 'one man show' with Nehru as its 'thaumaturgic personality'. ${ }^{147}$ It was not by accident that no one succeeded Patel as Deputy Prime Minister even when Nehru's health was severely debilitated by health scares in his last years. ${ }^{148}$ Gandhi, though never a real threat to Nehru's constitutional position as Prime Minister, was a powerful cultural factor and had the greater popular and messianic leadership that was still obvious in the remaining years of his remarkable life, which ended tragically in January 1948. Before he died he transferred his following to Nehru as the Mahatma's chosen heir. For political and executive leadership, however, Nehru, to complete his suzerainty over the State, Cabinet and Party, had to wait for the temporal departure of his Deputy Prime Minister: the solid Sardar Patel.

\section{Cabinet Duumvirate by Concession 1947-1950 - Nehru and Patel}

On 15 August 1947, Nehru handed to Mountbatten, now Governor-General of the Dominion of India, an envelope containing the list of the first Cabinet, which was to be sworn in a few hours later. It was empty! ${ }^{149}$ The excitement of the day created such an oversight but only two names counted - Nehru and Patel. These were two very different men. As Michael Brecher argues: 'no two leaders of any Asian nationalist movement in the twentieth century differed more than the duumvirs of the new India in background, education, temperament, ideology, sources of power, qualities and defects of leadership'. ${ }^{150}$ Nehru the refined patrician and worldly aesthete with lofty attachment to secularism and socialism and an aversion to petty politics was countered by a man in Patel with his dour manner and lowly background, but who was thoroughly at home in the orthodox Hindu milieu, with whom he saw represented India and the Congress Party, with which he was so involved at every organisational level. Nehru and Patel tolerated each other politically since they knew India, Congress and Gandhi expected them to function well for the good of the country. With the first Ministry of independence Nehru wanted to create, and was under pressure to form, a Cabinet that widely represented India. The Cabinet contained prominent non-Congressmen like Ambedkar, S. Chetty, Mathai and S. P. Mookherjee as well as influential Congressmen like Prasad and Azad and yet 'it was not the presence of these men which really limited

\footnotetext{
${ }^{147}$ Gopal, Jawaharlal Nehru - A Biography, Volume Two: 1947-1956, pp 304, 312-313

148 The position of Deputy Prime Minister was only revived again seventeen years later in 1967 when, like he father, Indira Gandhi was forced to appoint a powerful opponent to the position - namely Moraji Desai.

${ }^{149}$ Viceroy's Personal Report No. 17, 16 August 1947 in Constitutional Relations Between Britain and India - The Transfer of Power 1942-7, Vol. XII, p 771

${ }^{150}$ Brecher, Nehru - A Political Biography, p 151
} 
Nehru's supremacy in the Cabinet. It was Sardar Patel's powerful personality that prevented Nehru from having that amount of freedom in the Cabinet which he came to have after 1950 [with Patel's death]'. ${ }^{151}$

Patel became Deputy Prime Minister naturally and chose the powerful Home Ministry and States Ministry to abet his clout. They functioned in many ways as co-equals and many in Congress had not forgotten that if it had not been for Gandhi's intervention in the 1946 Congress Presidential elections in Nehru's favour, Patel could have become Prime Minister with his Party support, which Richard Sisson believes reflected 'the ambiguity that existed with respect to the locus of ultimate political authority' ${ }^{152}$ As everyone knew, 'the duumvirate was the decisive fact of Indian politics from Partition until the end of 1950. Though the procedures of cabinet government were followed, Nehru and Patel dominated the proceedings. It was the same in Parliament, the Congress and the country at large' ${ }^{153}$ They maintained amorphous spheres of influence with Patel's fiefdom containing party, organisational and administrative matters while Nehru was largely ascendant in foreign affairs and constitutional matters. However, all issues mentioned above still required at the very least the acquiescence of the other and acted as a democratic check on the other and a formidable form of horizontal accountability on the Prime Minister. Areas of domestic and economic policy were constantly a ground of contention. As Gopal argues:

Their temperamental and ideological differences had been kept under control in earlier years by the transcendent leadership of Gandhi and by the common commitment to the cause of India's freedom. But now, with independence and the steady weakening of Gandhi's authority, it was difficult for these preeminent men, one with a massive hold on popular affection and the other with a sure grip on the Party, to work together in the unaccustomed field of administration. $^{154}$

\footnotetext{
${ }^{151}$ Venkateswaran, Cabinet Government in India, pp 55-57. Also see Gangal, Prime Minister and the Cabinet in India, pp 46-49 on the formation of the first Ministry.

${ }^{152}$ Richard Sisson, "Prime Ministerial Power and the Selection of Ministers in India: Three Decades of Change”, International Political Science Review, Vol. 2, No. 2, 1981, pp 140-141 and for an unsympathetic and opinionated appraisal of Nehru's rise to the Prime Ministership see Y. G. Bhave, The First Prime Minister of India, New Delhi: Northern Book Centre, 1995, p 14. Bhave, for example, states that 'Nehru's lack of political wisdom and administrative foresight looked so ridiculously incongruous with the important post he was holding. Compared to Patel's towering personality as the "Iron Man of India", Nehru looked not even a wax pygmy.'

${ }^{153}$ Brecher, Nehru - A Political Biography, p 153

${ }^{154}$ Gopal, Jawaharlal Nehru - A Biography, Volume Two: 1947-1956, p 37
} 
This naturally created tension, rivalry and bickering, which would lead to threat of political war between the two Consuls within months of taking power from the British over who was Caesar or at least labelled as such.

\section{The Nehru Version of First Among Equals}

The heated correspondence between Patel and Nehru between December 1947 and February 1948 demonstrated the larger complications over conventions and lines of power between a Prime Minister and Ministers. Patel had long considered since joining the Cabinet that Nehru did not recognise his importance and was becoming increasingly dictatorial while Nehru believed that as Prime Minister he had seniority over his Deputy and had to be respected as such. Matters came to a critical juncture in late December 1947. Nehru and Patel exchanged heated correspondence, which was in the GovernorGeneral's knowledge and was usually and conspicuously enclosed to Gandhi as well, who was the recipient of their incessant arguments concerning constitutional frustrations. Nehru on 23 December 1947, replying to Patel's criticisms of prime ministerial interference into Patel's domain, reacted by writing that 'If I am to continue as Prime Minister I cannot have my freedom restricted and I must have a certain liberty of direction' and with preciousness added that if this were not possible 'it is better for me to retire'. ${ }^{155}$ Patel was not to be subdued by such prime ministerial emotions and explained:

You seem to feel that my action in explaining what I consider to be probable consequences of any action taken by you regarding matters which fall within my ministerial responsibility or in venturing to question the propriety or soundness of any action which ignores or affects such responsibility results in restraining or constraining your liberty or your freedom which you consider necessary for the due discharge of your responsibility. I am afraid I cannot subscribe to this view.

Patel ended by dismissing Nehru's resignation threat since 'the question of your abdicating your functions does not arise at all' and provocatively promised in the task of maintaining their relationship to 'strain every nerve to help you in doing so but you will not, I am sure, want me to continue long as an ineffective colleague'. Patel continued to

\footnotetext{
${ }^{155}$ Nehru to Patel, 23 December 1947, Selected Works of Jawaharlal Nehru, Second Series, Volume 4, S. Gopal (ed.), New Delhi: Jawaharlal Nehru Memorial Fund, 1984- pp 538-539
} 
question the Prime Minister's definition of the conventions surrounding their offices: ' $[\mathrm{u}]$ nder the restrictions [of] ministerial responsibility which you consider legitimate and which ... would include even another minister's encroachment [Patel was alluding to his belief that Nehru used more malleable Ministers to do his interfering], under your direction, on such responsibility, it would be impossible to continue'. ${ }^{156}$

Nehru re-entered the constitutional clash over their definition of convention by writing to Patel on 11 January suggesting they 'meet at Gandhiji's place for a further talk on this subject'. ${ }^{157}$ He enclosed a fantastic letter he had written to Gandhi on 6 January that addressed his view on an Indian Prime Minister's role. Nehru, after dealing with 'relatively minor matter[s]', stated that any differences between Patel and himself 'essentially relates to the functions of the Prime Minister. It is something much more than a personal issue and it should be considered, therefore as a question of principle, whoever the Prime Minister might be'. Nehru outlined his brand of New Westminster Prime Ministership and argued that 'in the type of democratic set-up we have adopted, the Prime Minister is supposed to play an outstanding role. This, I think, is important (again apart from personal factors) as otherwise there will be no cohesion in the Cabinet and the Government and disruptive tendencies will be at work'. Nehru described the role of a minister, including his own experience as Foreign Minister, but asserted that as Prime Minister 'I have a special function to perform which covers all the Ministries and departments and indeed every aspect of governmental authority'. Nehru reminded Patel of this especial Westminster characteristic, stating that a Prime Minister has unique role and power and that 'this function cannot be easily defined and the proper discharge of it depends a great deal on the spirit of cooperation animating all the parties concerned'. ${ }^{158}$

After describing a relatively minor topic of contention over Nehru's involvement in an area Patel deemed his ${ }^{159}$, Nehru dramatically enquired of the Deputy Prime Minister the wider question of power in their executive eyrie:

\footnotetext{
${ }^{156}$ Patel to Nehru, 24 December 1947, in Vallabhbhai Patel, Sardar Patel's Correspondence 1945-50, Vol. VI, Durga Das (ed.), Ahmedabad: Navajivan Press, 1973, pp 12-13

${ }^{157}$ Nehru to Patel, 11 January 1948, Selected Works of Jawaharlal Nehru, Second Series, Volume 5, p 475

${ }^{158}$ Note to Mahatma Gandhi, 6 January 1948, Selected Works of Jawaharlal Nehru, Second Series, Volume 5, pp 471-472

${ }^{159}$ Nehru had sent a personal emissary to Ajmer over the head Patel and the Chief Commissioner of the district in Selected Works of Jawaharlal Nehru, Second Series, Volume 5, pp 472-473
} 
Is the Prime Minister entitled to take such a step and who is to be the judge of this? If the Prime Minister cannot even take this step and is not himself to be the judge of what is proper and what is not in such matters, then he cannot function properly or fulfil his functions. Indeed he does not function at all as the Prime Minister should. The mere fact that he is Prime Minister presumably leads to the conclusion that he is capable judging aright and carrying out the policy laid down. If he is not capable of this, then he should cease to be Prime Minister. Indeed, this means abdication of his functions and cannot in future function with any effectiveness ... If this view is correct, then the Prime Minister should have full freedom to act when and how he chooses... ${ }^{160}$

Such a view could lead to the natural assumption that Nehru viewed himself as a delegated democratic Prime Minister with the power "to act when and how he chooses". Nehru then speculated that Patel may have difficulty with his interpretation and the 'best way out these difficulties would be for some rearrangement in the Cabinet to be made which would cast the responsibility on one person more than anyone else' and offered to go himself but added that 'there can be little doubt that if either of us goes out at the present juncture it would create a sensation both nationally and internationally, and the consequences may not be good'. However, he believed that 'the Prime Minister's function as defined above must be appreciated'. After outlining his belief that Patel himself had made decisions in the States Ministry "without any reference to Cabinet' he saw that if Patel did not agree with his Prime Ministerial definition then the only alternative would be for 'either me or Sardar Patel to leave the Cabinet' ${ }^{161}$

Patel replied the next day and copied Nehru's tactic of addressing his concerns to Gandhi directly. After stating that he and Nehru had through their joint efforts weathered 'one of the most critical phases in the history of any country or any government' admitted that 'we cannot carry this any further' and acknowledged the 'strength of feeling and conviction behind the Prime Minister's stand as regards to his own position'. However Patel, without surprise, was quick to critique the Head of Government's own job description though he tried to understand it 'on the twin basis of democracy and Cabinet responsibility' was still 'unable to agree with his conception of

\footnotetext{
${ }^{160}$ Note to Mahatma Gandhi, 6 January 1948, Selected Works of Jawaharlal Nehru, Second Series, Volume 5, p 473

${ }^{161}$ Note to Mahatma Gandhi, 6 January 1948, Selected Works of Jawaharlal Nehru, Second Series, Volume 5, p 474-475
} 
the Prime Minister's duties and functions.' Patel vividly continued the dangers of Nehru translation of prime ministerial power:

That conception, if accepted would raise the Prime Minister to the position of a virtual dictator, for he claims "full freedom to act when and how he chooses." This in my opinion is wholly opposed to democratic and cabinet system of government. The Prime Minister's position, according to my conception, is certainly pre-eminent; he is first among equals. But he has no overriding powers over his colleagues; if he had any, a Cabinet and Cabinet responsibility would be superfluous. ${ }^{162}$

Patel's conception of Cabinet relied on the argument that ministers had the 'entire responsibility' of implementing Cabinet decisions in their own ministry and that 'the Prime Minister should influence by way of consultation' not by edict. Patel believed his version 'in accord with the UK practice' showing the Indian leaders' attachment to Westminster operational culture. ${ }^{163}$ The seventy-two year old Congress veteran concluded by telling his fifty-eight year old boss that 'if anybody has to go it should be myself' ${ }^{164}$ Nehru characteristically replied promptly the next day and contended that it was hardly 'worthwhile my attempting to write another note on the subject. Having indicated our respective viewpoints to some extent, the only remains is for us to discuss this matter with Bapu [Gandhi]'. But Nehru could not resist in thrusting a parry at Patel at the end of his letter: 'There is no question, of course, of the Prime Minister or anyone else being a dictator' adding 'so far as I know, the position in practice in the United Kingdom is in consonance with what I suggested'. He concluded that they must settle these issues and 'as soon as the opportunity arises we shall be able to fix up a meeting with Bapu'. ${ }^{165}$ In addition it is interesting to note that Nehru felt it necessary to admonish Ambedkar, as Law Minister, for speaking publicly against the Congress leadership and their slowness to accommodate the Scheduled Castes. Just four months after his correspondence with Patel, Nehru told Ambedkar, a non-Congress Cabinet Minister, that 'if ministers feel and speak in this way there is no Cabinet responsibility

\footnotetext{
${ }^{162}$ Patel to Nehru and Patel's Note to Mahatma Gandhi, 12 January 1948, in Sardar Patel's Correspondence 1945-50, Vol. VI, pp 21-22

${ }^{163}$ Patel to Nehru and Patel's Note to Mahatma Gandhi, 12 January 1948, in Sardar Patel's Correspondence 1945-50, Vol. VI, p 22

${ }^{164}$ Patel to Nehru and Patel's Note to Mahatma Gandhi, 12 January 1948, in Sardar Patel's Correspondence 1945-50, Vol. VI, p 24

${ }^{165}$ Nehru to Patel, 11 January 1948, Selected Works of Jawaharlal Nehru, Second Series, Volume 5, p 476
} 
left. The Prime Minister might as well shut up shop' reminding him that he was part of 'essentially a Congress Cabinet'. ${ }^{166}$ Though this was a strictly correct Westminster interpretation it did little to accommodate the irregular circumstances of the early years of cabinet government.

The meeting with the Mahatma to debate the powers of a Prime Minister of India was never to happen since just over two weeks later on 30 January Gandhi, their political guru and arbiter, was felled by a Hindu assassin and waves of grief across the country drowned the immediate divergences within the Duumvirate. In the four years that Patel was a Cabinet Minister he threatened to resign at least four times, interestingly he tendered his resignations to Gandhi thrice and once to the then Party President, Rajendra Prasad, but pointedly never to Nehru who as Prime Minister was ultimately responsible for the selection and removal of all ministers, which was one the few powers of the Prime Minister constitutionally codified in the 1950 text. $^{167}$ After Gandhi's death Patel continued to hinder Nehru's sovereignty of political manoeuvre, but Patel's own death would follow Gandhi's in under two years. A seasoned Indian Mandarin, V. P. Menon, who played a vital administrative role in the transfer of power and became a leading civil servant working with both Nehru and Patel, assessed the importance of their relationship as a form of horizontal accountability at a critical early stage:

It was, indeed India's good fortune that during the initial stage of freedom, the destinies of the country were jointly entrusted to Pandit Nehru and Sardar Patel. One provided ideology while the other furnished realism ... both Nehru and Patel were compelled to turn their searchlight inwards and think of the possible reaction to the other. This avoided the two extremes; and in politics, the middle course is always the safest. It is, in my opinion, the greatest tragedy that this combination should have lasted only for forty months after the transfer of power. $^{168}$

\footnotetext{
${ }^{166}$ Nehru to Ambedkar, 27 April and 30 April 1948, Selected Works of Jawaharlal Nehru, Second Series, Volume 6, pp 373-374 and 377-379

${ }^{167}$ Gangal, Prime Minister and the Cabinet in India, pp 48-49. Article 75 (1) of the 1950 Constitution:

'The Prime Minister shall be appointed by the President and other Ministers shall be appointed by the President on the advice of the Prime Minister.'

${ }^{168}$ Cited in Venkateswaran, Cabinet Government in India, p 58
} 


\section{Head of State}

In 1952 Sir Ivor Jennings' peered into the executive sanctum of the Indian Union and noted with satisfaction the seeming faithfulness to Westminster norms in India despite becoming a republic. He wryly commented that 'true the Queen and the Crown have disappeared, but the Governor-General and the Governors reappear as President, Governor and Rajpramuks. Quite often the draftsmen had difficulty in finding a phrase to replace "Crown"”. 169 Though there is considerable validity to Jennings' impression that India retained much of the prevailing Westminster ways without the symbolic and dignified parts, there are still essential difficulties in such an assessment. The fundamental difficulty was more than a mere substitution of names at the executive table. The dissolution of the centralised executive, almost despotic, power vested in the Viceroyalty was to be distributed between the new executive actors. Executive power, regardless of constitutional stipulations and statutes, was fluid in this era. Even the stopgap period of Dominionhood demonstrated executive ambiguity.

\section{The Indian Governors-General - Influence without Power}

The last Viceroy of India, Earl Mountbatten of Burma, at the invitation of the Indian Cabinet, became Governor-General of India (but not Pakistan as well, which he also wanted $^{170}$ ), outwardly swapping the supreme plenipotentiary powers of a Royal Consul to become a constitutional cipher. However, this was not quite the case. As his official biographer records:

The role of Governor-General in an independent Dominion can be as important or as trivial as that of the constitutional monarch on whose behalf he acts as Head of State. Depending upon circumstances, the Governor-General may be little more than a decorative figurehead, opening bazaars and greeting foreign potentates, or a major force in the shaping of foreign and domestic policy. When he recently stepped down from a position close to that of absolute ruler, and his Government is preoccupied with enjoying and demonstrating its independence, it might be anticipated that he would rarely be allowed to trespass beyond formal. Mountbatten believed that his relationship with Nehru was

\footnotetext{
${ }^{169}$ Five Years of Independent India, c. 1952, Sir Ivor Jennings Papers, India C16, ICS125, Institute of Commonwealth Studies, London [henceforth ICS]

${ }^{170}$ Viceroy's Personal Report No. 11, 4 July 1947, Constitutional Relations Between Indian and BritainTransfer of Power 1942-7, Vol. XI, pp 898-900 and Hamid Khan, Constitutional and Political History of Pakistan, Karachi: Oxford University Press, 2004, p 86
} 
sufficiently close to ensure that behind the scenes his advice would be asked for and sometimes heeded, but he neither expected nor desired that he would perform a more overt role. He looked forward to with some satisfaction to nine months or so of relative tranquillity in which he would play the elder statesman and leave the hurly-burly of executive government to those who had fought so long for it. Within two weeks it became apparent that no such dispensation was to be allowed him. ${ }^{171}$

The extraordinary case of India warranted extraordinary uses of vice-regal power. Mountbatten was heavily involved in the negotiations with the Princely states and advocating their admission into the Indian Union. Mountbatten's defence background lent itself to his active role in the security of India such as with the refugee crisis that accompanied Partition and of course the enduring issue of Kashmir. The violence that greeted Partition meant that the Governor-General for instance took the initiative of establishing an "Emergency Committee" with himself as chairman with the backing of Nehru and Patel. This cabinet-authorised committee had 'powers [that] could hardly have been more sweeping and Mountbatten ... exercised them with a will'. ${ }^{172}$ Another extraordinary role for the new Governor-General was to chair the crucial Joint Defence Council to settle security issues between India and Pakistan. As the last Viceroy and first Governor-General he was also instrumental in the allocation of assets of Imperial India between the two Dominions, which Nehru and Jinnah (now Governor-General of Pakistan) believed could be done by no other. ${ }^{173}$ Not unnaturally therefore given the situation and his experience Mountbatten 'had clear ideas about his role as GovernorGeneral, though circumstances frequently forced him - not always unwillingly - to step beyond its limitations'. ${ }^{174}$

The greatest potential for the Governor-General to use his powers of making the Prime Minister horizontally accountable to him was through his very intimate and close relationship with Nehru. Though Mountbatten's powers were not as substantial as he

\footnotetext{
${ }^{171}$ Philip Ziegler, Mountbatten - The Official Biography, London: Collins, 1985, p 429

${ }^{172}$ Ziegler, Mountbatten - The Official Biography, pp 431-456

${ }^{173}$ Jinnah thought that Mountbatten should stay as a "Super Governor-General" over both Dominions to administer the distribution of assets. Viceroy's Personal Report No. 11, 4 July 1947, Constitutional Relations Between Indian and Britain - Transfer of Power 1942-7, Vol. XI, pp 898-900; Khan, Constitutional and Political History of Pakistan, pp 86-88 and Brown, Nehru - A Political Life, pp 176179

${ }^{174}$ Ziegler, Mountbatten - The Official Biography, p 461
} 
later liked to claim, he did to a large degree hold the confidence of Nehru and Patel. ${ }^{175}$ Mountbatten appreciated the massive burden on the shoulders of Nehru. Mountbatten from his time as Viceroy was able to utilise his deep knowledge of personnel to influentially advise Nehru and Patel on key military, diplomatic, political (at central and state level) and civil service appointments. ${ }^{176}$ One of his greatest services to India and its constitutional health was to emphasise to the premier rivals in Cabinet, Nehru and Patel, the value of working together. As was discussed above, the political relationship between these two dominated India till Patel's death in 1950 and the friction between the two men hampered policy and decisions of the central government.

The tension generated at this time was considerable and Mountbatten was able with the authority that no one but Gandhi could have over Nehru to reprimand his Prime Minister on his dealings with the Cabinet, thus offering a personalised and unique form of horizontal accountability. After discussing Nehru's inability to delegate or include ministers in key decisions such as Kashmir, the cousin of the last Emperor of India, told his Prime Minister that 'apart from differences of outlook, ideology and temperament, needless friction was being caused between the Prime Minister and the Deputy Prime Minister on account of faulty procedure'. Mountbatten continued about the Indian Prime Minister's political high-handedness with boldness that few others would have attempted telling Nehru 'what I had told Gandhi and Sardar Patel about his own shortcomings. I told him that in my opinion not even Mr Churchill, in the heyday of his power, would have dared to ride roughshod over his ministers in the way that Pandit Nehru appeared to be doing...' showing the lack of horizontal accountability in this crucial era. ${ }^{177}$ The Governor-General was also able to convince the Cabinet to make the unostentatious and security blasé Nehru move in to the grand former residence of the Commander-in-Chief, which became known as Teen Murti House ${ }^{178}$, though he did insist on taking out the air-conditioning of his bedroom during a power shortage (and even checked the power bills of the President and some of his ministers!). ${ }^{179}$

\footnotetext{
${ }^{175}$ Gopal, Jawaharlal Nehru - A Biography, Volume Two: 1947-1956, p 18

${ }^{176}$ For example the Governor-General's influence was crucial in regards to central-state relations. See Nehru to Mountbatten, 6 November 1947, in Jawaharlal. Nehru, Selected Works of Jawaharlal Nehru, Second Series, Volume 4, pp 472-473

${ }^{177}$ Lord Mountbatten's Record of Interview with Nehru, 5 February 1948, Selected Works of Jawaharlal Nehru, Second Series, Volume 5, pp 480-481

${ }^{178}$ After his death in 1964 it became the Nehru Memorial Museum and Library

${ }^{179}$ Brown, Nehru - A Political Life, p 191
} 
Mountbatten's unprecedented role and influence was one fraught with crisis and constitutional ambiguity. Nehru was able to recognise Mountbatten's role and even asked him to stay on further than was agreed. ${ }^{180}$ Mountbatten 'was not indispensable; but he felt himself to be almost so; it was in part this apprehension of impending indispensability that led him to insist on quick retirement'. ${ }^{181}$ Nehru was generous enough to vocalise his earnest gratitude in a formal Cabinet Resolution in Mountbatten's honour for an Englishman who operated in a time of 'upheavals and great difficulties. When all those who were concerned with the governance of India, Lord Mountbatten, functioning completely as a constitutional Governor-General, nevertheless helped greatly in lightening the burden and in helping to face and solve the problems that confronted the country. His period of office has been memorable in the history of India and he will be remembered by the people of India with affection as one who cooperated in the great task of building a free India and who applied his great abilities and energy to this end'. ${ }^{182}$

Mountbatten, in keeping entirely with his disposition, could not resist producing a memorandum or 'political testament' that he sent to Nehru, Patel and his successor C. Rajagopalachari $^{183}$ on the eve of his departure, that contained a 'ragbag of recommendations, almost all of them sensible and practical, which in their mixture of the significant and the trivial, the strategic and the tactical, are wholly characteristic of the author'. As well as idiosyncratic Vice-Regal edicts on press conferences, holidays for ministers and air conditioning in Government buildings, Mountbatten also advised on cabinet reconstruction, economic policy, appointments of Ambassadors and Governors, that Nehru should drop the Foreign Affairs portfolio and was concerned that the new constitution 'might be taken as a sacred text and thus be unnecessarily rigid'. ${ }^{184}$ Whatever else, Mountbatten's stature and experience made the post of GovernorGeneral a significant one and not cipher as in many New Westminsters like New Zealand.

\footnotetext{
${ }^{180}$ Mountbatten agreed to stay on till June 1948. Lord Mountbatten's Record of Interview with Nehru, 14 January 1948, Selected Works of Jawaharlal Nehru, Second Series, Volume 5, p 477

${ }^{181}$ Ziegler, Mountbatten - The Official Biography, p 475

182 'The Services of Lord and Lady Mountbatten', 20 June 1948, Selected Works of Jawaharlal Nehru, Second Series, Volume 6, p 357

${ }^{183}$ C. Rajagopalachari was more popularly known as C. R. or Rajaji

${ }^{184}$ Ziegler, Mountbatten - The Official Biography, pp 476-477
} 
There was therefore great interest as to who would and should succeed him. Mountbatten's first choice was Patel ${ }^{185}$, which indicates that he wanted a powerful personality at Sir Edwin Lutyen's Imperial Palace perhaps to counter Nehru's political pre-eminence. Interestingly, the man who did get the post and who also had Mountbatten's approval, the prominent Tamil Brahmin and leading Congressman, C. Rajagopalachari hesitated before accepting the post. Rajagopalachari believed that Nehru himself should become the King's Representative with Patel as Prime Minister. To this private and extraordinary idea Rajagopalachari, presently Governor of West Bengal, argued, perhaps with an eye to Jinnah's Pakistan, that Nehru would have 'greater power' and the arrangement would be 'of great international value [and] more efficient for internal affairs'. Nehru's brittle reply concluded against the suggestion by saying that 'internationally it is bad, internally it is also unsuitable. Temperamentally it could not also do'. ${ }^{186}$ Rajagopalachari finally acquiesced and became the first and last Indian to be Governor-General, an unlikely successor to a long line of proconsuls beginning with Warren Hastings. Outwardly the change from a great-grandson of the first Empress of India to a Hindu teetotaller ${ }^{187}$ was striking.

However, despite the outward contrast of these two Governors-General, both men were seasoned in the ways of India and more notable still was the confidence they inspired from the key political actors in the Indian executive. Rajagopalachari, a South Indiantrained lawyer and religious scholar with a savouring for Shakespeare was close to Gandhi not only in looks, but also in independence of spirit and action. Nehru had certainly not recommended the appointment of a politically impotent or inept person to occupy the Governor-General's throne. Nehru believed Rajagopalachari's 'presence in Delhi will be a great help to all of us, and especially to me ${ }^{188}$ and more than just a figurehead he was implored with the plea: 'We want you here to help us in many ways. The burden on some of us is more than we can carry'. ${ }^{189}$

\footnotetext{
${ }^{185}$ Ziegler, Mountbatten - The Official Biography, p 475

${ }^{186}$ Nehru to Rajagopalachari, 21 May 1948, (also see footnote 2, page 356), Selected Works of Jawaharlal Nehru, Second Series, Volume 6, p 356

${ }^{187}$ One of Rajagopalachari's first instructions was that 'in regard to stocks of liquor, the GovernorGeneral Designate said that he did not wish to have any of this on his charge' in contrast to the Mountbatten regime. See minutes of a meeting between His Excellency [Mountbatten] and the GovernorGeneral Designate [Rajagopalachari] at 10 am on Friday, 4 June 1948, in C. Rajagopalachari Papers, NMML

${ }^{188}$ Nehru to Rajagopalachari, 30 March 1948, in C. Rajagopalachari Papers, NMML

${ }^{189}$ Nehru to Rajagopalachari, 11 April 1948, in C. Rajagopalachari Papers, NMML
} 
The new Governor-General like his predecessor was compelled to wade into areas, which in normal circumstances would be considered as impolitic of a traditional Westminster Head of State. But these were not normal circumstances. The threatened secession of the large princely state of Hyderabad from the Indian Union was an example that spurred the Governor-General to actions normally unbecoming of his post, though this was working in concert with the Prime Minister and Cabinet, not as form of horizontal accountability on those executive actors. As Head of State, Rajagopalachari directly appealed and firmly stressed upon the eccentric and wizened Muslim Nizam of this predominantly Hindu state to join the Union or face the consequences. His Exalted Highness was told that if he were not in agreement he would 'force the Government of India to act on their own initiative'. The Nizam's intransigence led to the GovernorGeneral summoning the Prime Minister and Deputy Prime Minister to his residence where it was decided to occupy Hyderabad. As Rajmohan Gandhi attests: 'C. R[ajagopachari]'s active role over Hyderabad, exceeding the scope of a constitutional head of state, was a product of the peculiar Nehru-Patel-C.R. relationship. C. R.'s views, and not just his signature, mattered to Jawaharlal and Vallabhbhai'.

Indeed on other occasions the veteran politician would philosophically ponder his role and that 'to sign assent when he did not agree was not pleasing for C. R.; at times he would enter next to his signature the words "Against conscience". Neither was it pleasing for Nehru or Patel when the Governor-General requested the Cabinet to reconsider a decision', which showed symbolic elements of horizontal accountability on the elected executive. These occasions were extremely rare, but demonstrated the regard he was held by his senior ministers. ${ }^{190}$

With the Republic about to be inaugurated in early 1950, Nehru thought that Rajagopalachari should be transformed into the first President of India and that he could therefore continue a close and fruitful relationship with the Head of State. However the relative freedom of selection that is afforded to Prime Ministers to directly influence the appointment of a Governor-General was not be repeated with the Republic. Nehru would face not only one his earliest major rebuffs over an executive appointment, but was to be given a Head of State that for the first time truly tested the constitutional relationship between a Head of State and Prime Minister. The tensions, interpretations

${ }^{190}$ Rajmohan Gandhi, Rajaji - A Life, New Delhi: Penguin Books India, 1997, pp 299-305 
and emanations of this relationship would shape India's executive practices permanently.

\section{The Prasad Presidency and the Search for Executive Norms}

Article 53 of the Republic of India's interminable constitution proclaims that 'Executive power of the Union shall be vested in the President either directly or through officers subordinate to him'; while Article 74 complements or mitigates this, depending on your executive vista, by explaining that 'there shall be a Council of Ministers with the Prime Minister at the head to aid and advise the President in the exercise of his functions', and thus hoped to give emphasis to the 'efficient' Westminster institutional convention of the Cabinet's binding advice on the Head of State without overtly making that legally difficult point clear. ${ }^{191}$ There were also certain controversial emergency powers, especially Article 356 which gave powers of the Centre over the States. These will be discussed in the path dependent chapter section below. Despite the Constitution's prolix nature and unprecedented length the section dealing with the executive of the Indian Union was relatively brief and lacking in definitive clarity while the rest of the executive section, as an eminent Indian Jurist argues 'was wisely left to convention and Constitutional practice'. ${ }^{192}$ India sought to stipulate in writing Westminster institutional executive conventions, but consciously did not add explicit and absolute detail that could confine or clarify the powers and boundaries of the executive and its political components. As Manor has commented, the framers of the Constitution enjoyed the acculturated familiarity and prestige of the British model and believed that their leaders would be like themselves - 'restrained and responsible'. As such they did not want their government to 'be hemmed in by detailed rules which might restrict its flexibility ... the result is a Constitution which says very little about relations between Presidents and ministers'. ${ }^{193}$ India may have been a Republic, but it was still an institutional Westminster mutatis mutandis.

Therefore the executive terms accepted above although radiating from the Commonwealth's first republic were almost as imprecise, misleading and vague as any

\footnotetext{
${ }^{191}$ Basu, Constitutional Law of India, p 141 and 151 It is interesting to note the similarity of Article 74 with Section 9 of the Government of India Act, 1935, provided that 'there shall be a Council of Ministers...to aid and advise the Governor-General in the exercise of this functions.'

${ }^{192}$ Fali S. Nariman, "The Office of the President", Journal of Constitutional and Parliamentary Studies, Vol. XXXVII, No. 1-4, January-December 2002, p 154

${ }^{193}$ James Manor, "The Prime Minister and President" in Nehru to the Nineties - The Changing Office of Prime Minister in India, pp 116-117
} 
Westminster constitution on such critical subjects. Dr Rajendra Prasad, the first President, was one of the first prominent politicians to question and then attempt to interpret such constitutional ambiguities. However, with an inevitability that can only result from such constitutional vagaries and flexibility, his decryption of executive power came into conflict with other members of the executive, namely the Prime Minister himself. Prasad had already noted his constitutional concerns when he wrote to Rau, in early 1948 as President of the Constituent Assembly, perhaps already with an eye for the powers of the Presidency of the Union that 'in a country like England where the system has been in vogue for a long time, traditions and conventions have made the working of the Constitution efficient but we need some safeguard in India where we do not have the same traditions to begin with' ${ }^{194}$ Unlike the regal processes that allow a Dominion Prime Minister to advise the appointment anyone they wish to the GovernorGeneralship, which elegantly evades the nuisance of elections or meddlesome involvement of Parliament, the President of India would require the sanction of electoral legitimacy albeit through indirect means. The Head of the Indian Union would be elected in the first instance by the Constituent Assembly and subsequently by an electoral college composed of the elected members of both Houses of Parliament and the elected members of the State Legislative Assemblies. ${ }^{195}$

As was mentioned above Nehru wanted Rajagopalachari to become President, who possibly would have been less trouble for the Prime Minister. Prasad's conservative Hinduism and penchant for making public such views irritated the stridently secular Nehru. ${ }^{196}$ However, Congress and the Constituent Assembly were behind Prasad. Nehru, as generally had been the way, believed he would get his way in bypassing his fellow Congressman Prasad for the Presidency. Nehru pressurised Prasad that he

... felt that the safest and best course from a number of points of view was to allow arrangements to continue, mutatis mutandis. That is that Rajaji might continue as President. That would involve the least change and the state machine would continue functioning as before ... to push out Rajaji at this stage would

\footnotetext{
${ }^{194}$ Prasad to Rau, 10 May 1948, in Rajendra Prasad, Dr Rajendra Prasad: Correspondence and Select Documents, Vol. IX, Valmiki Choudhary (ed.), New Delhi: Allied Publishers, 1987, p 51

${ }^{195}$ Durga Das Basu, Introduction to the Constitution of India, $18^{\text {th }}$ edition, New Delhi: Prentice-Hall, 1998, p 163

${ }^{196}$ For example 'Prasad enraged Nehru by suggesting a change in the date of Republic Day...because it was astrologically inauspicious. He also tried unsuccessfully to include Hindu rituals in his presidential installation ceremony.' See Manor, “The Prime Minister and President”, p 120
} 
be almost a condemnation of his work. That would be most unfortunate . . Vallabhbhai and I felt that Rajaji's name should be put forward for unanimous election. I hope you agree. In this matter it would of course be fitting for you to suggest this, rather than any other person. ${ }^{197}$

Just over a week later Prasad showed his mettle by informing Patel that '. . . there was much feeling among party members [in support of Prasad] and that 85 percent of members favoured my being President . . . ${ }^{198}$ Nehru had been prepared to go against such wishes of the Assembly ${ }^{199}$, but had overestimated his capacity to succeed. Rajagopalachari's biographer believes the reason for the Tamil Governor-General's disfavour with Congress and the Assembly was due to not only Rajagopalachari's inability in Hindi and distance from Delhi, but especially due to his antipathy towards the "Quit India" Movement in 1942. Rajagopalachari had instead called for accommodation with the British and the Muslim League during World War II when most of the Congress favoured active dissent. His unpopular stance on "Quit India" tarnished his nationalist credentials in many nationalists' eyes against the popularised jail terms under the British of Prasad and many others in the Assembly. ${ }^{200}$ In contrast to the practices in the New Westminsters, Prasad, President of the Constituent Assembly, was unanimously elected by his peers to become the first President of the Republic much to Nehru's chagrin.

With Prasad's election as Head of State the Prime Minister's wishes were institutionally checked by political accountability that was absent under the Dominion interregnum. Prasad would have agreed with the analysis of scholars fifty years after he assumed the highest office who argued that Indian Presidency 'has a residual identity separate from cabinet, parliament, and the civilian and military services - an identity beyond government and opposition, beyond partisanship, as representative of the interests of the

\footnotetext{
${ }^{197}$ Nehru to Prasad, 10 September 1949, Dr Rajendra Prasad: Correspondence and Select Documents, Vol. XI, p 152

${ }^{198}$ Prasad to Patel, 19 September 1949, Prasad: Correspondence and Select Documents, Vol. XI, pp 160162

${ }^{199}$ Introduction, Dr Rajendra Prasad: Correspondence and Select Documents, Vol. XII, p v

${ }^{200}$ Though Nehru held Rajagopalachari in the highest regard, especially intellectually, he did in fact share similar views to many Congressmen at the time on Rajagopalachari's contrasting utterances on communalism in the midst of tension with the Muslim League and Britain as Nehru confided to his prison diary the hyperbolic question 'is there a more dangerous person [Rajagopalachari] in all India?', Nehru, "Mental Perturbation”, 5 August 1944, in The Essential Writings of Jawaharlal Nehru, Vol. 2, pp 691692 and Gandhi, Rajaji-A Life, p 309
} 
nation'. ${ }^{201}$ K. M. Munshi, one of Prasad's great sympathisers, argued that the President should not be a mere figurehead but had to be the 'one strong organ of State' capable of dealing with crises and excessive prime ministerial power. ${ }^{202}$ The republican resident of Rashtrapati Bhavan ${ }^{203}$, no longer the residence of the Representative of the KingEmperor, had every intention of exercising the full prerogatives available to a Westminster Head of State as well as teasing and trying the unwritten conventions surrounding the powers of his office that had been thought superfluous to bother committing to paper only months before. This potential constitutional danger was noticed before Prasad's inauguration by Jennings, who with validity pointed out the liable dilemma of the Indian situation:

The Indian Constitution provides for an elected President who is apparently intended to be a Constitutional monarch without the trappings of monarchy. This is perhaps a somewhat hazardous experiment. Constitutional monarchy has evolved in Great Britain by a long and at times stormy process of evolution. It is easy to translate this system through the appointment of a Governor-General, but it may be less easy where an elected President, presumably a politician of some ambition, assumes royal functions. We have trained our kings, and GovernorsGeneral copy kings. There is some risk that a President will desire to set his own precedents and the Council of Ministers will not always agree with him. Rather than accept allegiance to the former Emperor of India, the Constituent Assembly prefers to run the risk. ${ }^{204}$

With this in mind, Prasad would hold true to his sworn oath to "preserve, protect and defend the Constitution, ${ }^{205}$, or at least as he interpreted it.

\section{The Hindu Code Bill - President vs. Prime Minister}

Before becoming President Prasad told his countrymen in the Constituent Assembly that one could assume that

\footnotetext{
${ }^{201}$ Lloyd I. Rudolph and Susane Hoeber Rudolph, "Redoing the Constitutional Design: From an Interventionist to a Regulatory State" in The Success of India's Democracy, p 141

${ }^{202}$ K. M. Munshi, The President under the Indian Constitution, $2^{\text {nd }}$ edition, Bombay: Bharatiya Vidya Bhavan, 1967, pp iv-vi

${ }^{203}$ The new name of the Viceroy's Palace when India became a Republic in 1950

${ }^{204}$ Sir Ivor Jennings, British Year Book of International Law 1948, p 416 cited in Prasad, President's Status vis-à-vis Council of Ministers, 24 January 1951, Dr Rajendra Prasad: Correspondence and Select Documents, Vol. XIV, p 289

${ }^{205}$ The Oath or Affirmation by the President, Article 60, in Basu, Constitutional Law of India, p 145
} 
Although there is no specific provision in the Constitution itself making it binding on the President to accept the advice of his Ministers, it is hoped that the convention under which in England the King always acted on the advice of his Ministers would be established in this country also and that the President would be a constitutional President in all matters. ${ }^{206}$

Rau also believed that 'the relations between the President and the Council of Ministers shall, as far as possible, be the same as between the King and his ministers in England' and though the President 'will almost always act on the advice of Ministers'. However, 'there will be a few matters in respect of which he will have to act in his own discretion. Even in the English Constitution, there are certain matters in respect of which it is a moot question whether the King is bound to act on the advice of the Prime Minister'. ${ }^{207}$ As Rau correctly analysed the relationship in the main is one of correct procedure, but there is also potential for personal discretion and thereby friction between executive actors. As one scholar of presidentialism in South Asia has dramatically characterised it 'the President and his discretion are all that stand between order and chaos' since the President is the final check on executive actions. ${ }^{208}$ For there to be order and not chaos the executive actors must know and understand the powers and limits of their own office as well as the others offices within the Executive. Prasad noted that in England this understanding came 'from the diaries of kings or their consultants and Prime Ministers and other documents which were later published and which described the points of dispute' and recognised the importance of the first office holders in establishing precedents for future office holders. ${ }^{209}$

For the Indian Republic these were obviously not available and the debates of the Constituent Assembly, though useful for the purpose of ascertaining conventions, cannot be considered by themselves a sufficient source'. ${ }^{210}$ Prasad was quick to see the Presidential permeations all over the State, as the Crown had been, reading the Constitution literally to mean personal powers in the office of President. Just as the

\footnotetext{
${ }^{206}$ Cited in Basu, Introduction to the Constitution of India, p 188

207 "Confidential - Memorandum on the Union Constitution”, 30 May 1947, Rau Papers, NMML

${ }^{208}$ Jean-Alphonse Bernard, "The Presidential Idea in the Constitutions of South Asia", Contemporary South Asia, Vol. 1, No. 1, 1992, p 41

${ }^{209}$ Prasad Diary, 12 May 1952, Dr Rajendra Prasad: Correspondence and Select Documents, Vol. XV, p vi

${ }^{210}$ Alexandrowicz, Constitutional Developments in India, p 129
} 
fascinating correspondence between Patel and Nehru over their powers between late 1947 and early 1948 illustrated the wider difficulties in comprehending the conventions and powers between Prime Minister and Cabinet so would the astonishing frank exchange of enclosures and letters between Prasad and Nehru in September 1951. Prasad had cool, but largely correct relations with Nehru reminding the Prime Minister after less than a year as tenant of Rashtrapati Bhavan that all important Cabinet decisions must be communicated to him 'before they are issued to the Press or otherwise published ${ }^{211}$ and advised the Congress Prime Minister that Ambassadors and Governors should not attend or become delegates at Congress Party sessions. ${ }^{212}$ Prasad saw in the Presidency a greater policy and constitutional activism than had been contemplated by his Prime Minister, who wanted the more typically quiescent Head of State that existed in most New Westminsters. As Prasad explained to the Deputy Prime Minister:

I have, since coming to this office, been trying to feel my way as to how things are to develop ... Many things will develop in course of time by convention. A reference to the constitution itself shows that there are at least 121 Articles in it apart from the schedules, in which the President is mentioned as having to do something or other. There is no doubt that in most of these matters he has to act according to the advice of the Ministers concerned but I believe the Constitution contemplates that it is open to him to advise ministers not on matters of detail but generally on matters of policy ... There are certain articles in the constitution in which I believe there is some direct responsibility and the President also has corresponding obligations both towards ... officers and towards the Ministry as well as towards the people at large.$^{213}$

As a further portent of presidential intentions Prasad forewarns Nehru, addressing him as Prime Minister, not the informal Jawahahalji as had been the case previously, that though after reviewing a Bill for his urgent assent he did not 'desire to do anything which may create any embarrassment to you or to the Government. But I hope, you will concede that when I am asked to sign a document, I must satisfy myself and not

\footnotetext{
${ }^{211}$ Prasad to Nehru, 1 July 1950, Dr Rajendra Prasad: Correspondence and Select Documents, Vol. XIII, p 3

${ }^{212}$ Prasad to Nehru, 26 August 1950, Dr Rajendra Prasad: Correspondence and Select Documents, Vol. XIII, p 63

${ }^{213}$ Prasad to Patel, 27 August 1950, Dr Rajendra Prasad: Correspondence and Select Documents, Vol. XIII, pp 64-66
} 
sign blindly... ${ }^{214}$ Just two days shy of being President for a year Prasad produced a memorandum entitled On President's Status vis-à-vis Council of Ministers. Prasad believed it was his duty and constitutional privilege 'to influence the Council of Ministers by his advice'. Prasad grasped that as the very first President of India (and in the entire Commonwealth) he could shape the presidency in a way his successors could not.

I am anxious that nothing that I might do during my term of office should be such as to create a wrong precedent or may become the beginning of an undesirable convention ... I should not therefore like to do anything which would in any way fetter the discretion of my successors by becoming a precedent or convention. ${ }^{215}$

Prasad would certainly cause a precedent, but not quite what he intended, as we shall see below. Prasad contended that in contrast to his previous statements in the Constituent Assembly, the President was in fact attributed with not insubstantial powers that distinguish the Indian Presidency from the conventions surrounding the British parallel.

The position of the President is different from the King of England, in that he is an elected person who has to justify his election whereas a hereditary king is there by right of birth. Whatever the strictly correct legal and constitutional position may be, there is no doubt that in the case of an elected President, people do look upon him also as a person having some authority in the governance of the country, and he justifies his position only by tendering such advice and giving such suggestions to the Cabinet before it takes any decisions ... If he does not get therefore an opportunity of influencing the decision beforehand for any reason, the President becomes only an ornamental figure-head without the authority of a hereditary king and a costly non-entity. ${ }^{216}$

\footnotetext{
${ }^{214}$ Prasad to Nehru, 11 September 1950, Dr Rajendra Prasad: Correspondence and Select Documents, Vol. XIII, pp 76-77

${ }^{215}$ Prasad, President's Status vis-à-vis Council of Ministers, 24 January 1951, Dr Rajendra Prasad: Correspondence and Select Documents, Vol. XIV, pp 277-280

${ }^{216}$ Prasad, President's Status vis-à-vis Council of Ministers, 24 January 1951, Dr Rajendra Prasad: Correspondence and Select Documents, Vol. XIV, p 279
} 
Interestingly again in view of the debates of the Constituent Assembly, which had negated the idea, the new Head of State wanted 'Rules of Procedure' which would specify 'all the details of how the President, the Ministers and the Cabinet are to function in the discharge of their respective duties' and added the foreboding caveat that he wanted 'the above instructions to be carried out by my office'. ${ }^{217}$ Prasad obviously did not see the President of India as being mere figurehead who sycophantically signed Bills on command from the Cabinet. He had great expectations for the influence of the President over the governance and direction of the state. The President hoped to share power with his ministers. The contention would meet the opposition of his Prime Minister and Ministers.

The real crux of constitutional conflict would erupt over Nehru's legislative attempts to reform Hindu personal law concerning marriage, divorce, inheritance, property and women's rights with the Government's Hindu Code Bill at the vanguard of a secular assault to eliminate, in the Prime Minister's mind, the primordial atavisms that divided India. $^{218}$ Nehru had long harboured the ambition of modernising India and saw reform of archaic religious practices which permeated and manifested into Indian society as his way to succeed. ${ }^{219}$ The Hindu conservative President and his inflated interpretation of his powers came in to direct opposition with his Prime Minister on the matter and intended to use all his official powers to halt the Bill. His opposition to the Bill was more on policy and personal grounds than from a legal basis, though he chose to present them as a constitutional point. The conflicts between the Head of Government and Head of State went to the heart of India's Westminster Constitution and 'were at once substantive, institutional, and personal'. ${ }^{220}$ The clash over this Bill had been brewing for months, but came to the fore in September 1951. Prasad wrote to Nehru on 15 September noting that he had given 'public expression to my views' on the Hindu Code Bill before becoming President and since it looked like Parliament was set to pass the Bill he wanted to let the Cabinet be 'in possession of my views' and 'not be taken by surprise'.221

\footnotetext{
${ }^{217}$ Prasad, President's Status vis-à-vis Council of Ministers, 24 January 1951, Dr Rajendra Prasad: Correspondence and Select Documents, Vol. XIV, p 280

${ }^{218}$ For more detailed information on the Hindu Code Bill and political issues involved see Reba Som, "Jawaharlal Nehru and the Hindu Code: A Victory of Symbol over Substance", Modern Asian Studies, Vol. 28, No. 1, 1994, pp 165-194

${ }^{219}$ Som, "Jawaharlal Nehru and the Hindu Code: A Victory of Symbol over Substance", pp 169-172

${ }^{220}$ Austin, Working a Democratic Constitution, p 19

${ }^{221}$ Prasad to Nehru, 15 September 1951, Dr Rajendra Prasad: Correspondence and Select Documents, Vol. XIV, p 104
} 
Enclosing a note for the Cabinet's viewing he cautioned his Ministers that he may send a message to Parliament and expressed that his 'right to examine it [Hindu Code Bill] on its merits when it is passed by Parliament before giving assent to it is there' and ominously ended by saying that 'he may take such appropriate action as I may feel called upon to avoid such embarrassment consistently with the dictates of my own conscience'. ${ }^{222}$ Replying on the same day, Nehru immediately and formally indicated that he would pass on Prasad's note to the Cabinet with alacrity and starkly reminded the Head of State of the constitutional gravity of the situation:

These are serious matters of great constitutional importance. They might involve a conflict with the President on the one side and the Government and Parliament on the other. They would inevitably raise the question of the President's authority and powers to challenge the decision of Government and of Parliament. The consequences would obviously be serious ... in our view the President has no power or authority to go against the will of Parliament in regard to a Bill that has been well considered by it and passed. The whole conception of constitutional government is against any exercise by the President of any such authority. $^{223}$

Nehru was quick to point out to the President that policy was the Government's competence, not the President's and that the Government in Parliament represented the people, despite Prasad arguing that in his opinion the public were against the Bill, which the Prime Minister hotly refuted. ${ }^{224}$ In a further letter on this constitutionally cacophonic day, Nehru warned the President that the Press seemed to have wind of these top secret emanations, which could cause grave damage if the spat between the two became public, and lectured the Indian Head of State that 'they could only have got this information from Rashtrapati Bhavan'. ${ }^{225}$ Interestingly, despite Nehru's hectoring on constitutional protocol and importance of confidentiality he himself was passing on copies of the letters, which Prasad was not informed, to at least Rajagopalachari now

\footnotetext{
${ }^{222}$ President's Enclosure for Cabinet, 15 September 1951, C. Rajagopalachari Papers, NMML

${ }^{223}$ Nehru to Prasad, 15 September 1951, Prasad: Correspondence and Select Documents, Vol. XIV, pp 104-105

${ }^{224}$ Nehru to Prasad, 15 September 1951, Prasad: Correspondence and Select Documents, Vol. XIV, p 105-106

${ }^{225}$ Nehru to Prasad, 15 September 1951, Prasad: Correspondence and Select Documents, Vol. XIV, pp 106-107
} 
reincarnated as Home Minister in the Union Cabinet on the death of Patel. ${ }^{226}$ The President and the Prime Minister did not greatly sympathise with the others view as the temperature continued to rise. ${ }^{227}$

With a mere three-day break, the constitutional polemics resumed as the President repaired to the Viceroy's old summer residence in Simla now rechristened as Rashtrapati Niwas. Perhaps the vice-regal ghosts of Dufferin and Lansdowne inspired their Indian successor to renew the constitutional battle. Pleasantries were quickly dispensed with as the President responded pluckily to the Prime Minister:

It seems you are of the opinion that I have no right to inform of my viewpoint on a Bill before it or to examine it on its merits when it is passed by Parliament before giving my assent to it and my insistence might involve a conflict between the President on the one hand and the Government and Parliament on the other. No such conflict need arise if the Government and Parliament recognise wellunderstood and well-known democratic limitations on their power also... 228

Prasad's reading of 'well-understood and well-known democratic limitations' on the powers of the Cabinet and Parliament meant in his mind the ability of the President to question publicly and privately the policies of his Ministers who, as the Constitution stated in the British fashion, held 'office during the pleasure of the President'. ${ }^{29}$ Prasad continued and sought to justify his position by reminding the Prime Minister of his rights under the Constitution. Prasad argued that 'so far as our Constitution is concerned, it confers in unequivocal words on the President the right to address and send messages to Parliament ... [and] ... the right to declare either that he assents to a

\footnotetext{
${ }^{226}$ Nehru passed on the President's letters on to Rajagopalachari the very same day he received them along with his replies with the caution 'please keep these papers absolutely secret. No mention should be made of them to anyone'. See Nehru to Rajagopalachari, 15 September 1951, C. Rajagopalachari Papers, NMML. However, Prasad himself had been enclosing copies of their earlier disagreements with Nehru to Patel, before the Deputy Prime Minister's death in December 1950 and who definitely erred towards Prasad's Hindu conservatism. See Som, "Jawaharlal Nehru and the Hindu Code: A Victory of Symbol over Substance", p 172

${ }^{227}$ Nehru wrote to a Cabinet Minister on 22 September 1951: 'I regret to say that the President attaches more importance to his astrologers than to the advice of his Cabinet on some matters. I have no intention of submitting to the astrologers', cited in Gopal, Jawaharlal Nehru - A Biography, Volume Two: 19471956, p 155. Prasad confided to K.N. Katju that 'I have written as strongly as I could...I could not have done more', cited it Som, "Jawaharlal Nehru and the Hindu Code: A Victory of Symbol over Substance", p 185

${ }^{228}$ Prasad to Nehru, 18 September 1951, Prasad: Correspondence and Select Documents, Vol. XIV, pp 107-108

${ }^{229}$ Article 75 (2) in Basu, Constitutional Law of India, p 154
} 
Bill or that he withholds assent therefrom when it has been passed by Parliament and presented to him,. ${ }^{230}$ Prasad wanted to imply his right and his serious contemplation of sending a message to Parliament stating his objections to the Bill.

Prasad sought to neutralise this constitutional dilemma by pleading the difference of his own position as President compared to the British King. The President believed his role went beyond simply defending the constitution. Though he hoped that in most cases there would be no difference in opinion within the executive and that though the President will act in accordance with the conventions of British Constitution' there will be occasions 'requiring the President to take an independent line' since this is possible because 'the President, unlike the King of England, holds his office by virtue of election'. ${ }^{231}$ Prasad believed that he further insured his position by reminiscing from his days in the Constituent Assembly that "wherever the Constitution wanted that British conventions and practice should be imported and read into our Constitution, it has expressly laid it down ... I am, therefore, of the view that the Constitution does not admit of a wholesale importation of all practices and conventions of the British Constitution'. ${ }^{232}$

However Prasad wished to have the best of all constitutional worlds by stating that 'the same conventions of the British Constitution which limit the King's powers also limit the powers of the Government and the Parliament to sponsor and force such legislation without consulting the electorate' ${ }^{233}$ This was also a reference to his conviction that the present Parliament was merely a 'caretaker body' since general elections by full adult franchise would not happen till 1952, though an analogous argument could be made of him as he had been elected by the very limited electorate of the Constituent Assembly and not the semi-direct election of the State Legislatures and Houses of Parliament that a President would normally be elected from. Prasad by denying the legitimacy of the present Parliament and righteously claiming that it 'would not be right to import and insist on some conventions and ignore others' made the extraordinary suggestion that

\footnotetext{
${ }^{230}$ Prasad to Nehru, 18 September 1951, Prasad: Correspondence and Select Documents, Vol. XIV, p 108

${ }^{231}$ Prasad to Nehru, 18 September 1951, Prasad: Correspondence and Select Documents, Vol. XIV, p 108

${ }^{232}$ Prasad to Nehru, 18 September 1951, Prasad: Correspondence and Select Documents, Vol. XIV, pp 108-109

${ }^{233}$ Prasad to Nehru, 18 September 1951, Prasad: Correspondence and Select Documents, Vol. XIV, pp 108-109
} 
'the electorate, which is master both of Parliament and the President, should be given a chance to express itself on the merits of the Bill' by means of a referendum. ${ }^{234}$

This postulation would have pitted the President and Cabinet against each other in an executive internecine war over policy and would have brought the young Republic to its knees. The President, thinking he was defending his rights and the Constitution, was in fact eroding the office's prerogatives and discretions by disputing the powers of the Prime Minister, Cabinet and Parliament. Prasad, though claiming to be, was not defending the Constitution but being obstructive and finicky over a Bill that pertained to policy not the mores, Westminster or Indian, of the Constitution.

In the meantime Nehru was swift to enlist the learned opinions of the Attorney-General, M. C. Setalvad, and the distinguished jurist, who we have encountered above, Sir Alladi Krishnaswami Aiyar. Aiyar explained robustly on 20 September 1951 that 'the provisions of the Indian Constitution...makes it perfectly clear that the President is in every respect in the position of a constitutional monarch in England or his representative in the Dominions, namely, the Governor-General and that there is no sphere of his functions in respect of which he can act without reference to the advice of his ministers'. Though admitting that the Indian Constitution 'did not go into details in this regard' Article 74 was 'sufficiently clear' that the President exercises his executive powers with the 'aid and advice' of his Ministers. Aiyar accurately pointed out that 'in not stating in detail the incidents of responsible government, our Constitution has followed the example of most Dominion Constitutions'. The Madras based lawyer further illustrated his point that the President was bound by the advice of his Ministers by drawing on the constitutional canons of Asquith, Halsbury, Dicey and of course Jennings to defend cabinet government against Prasad's arguments. ${ }^{235}$

The Attorney-General, unsurprisingly, produced strong legal arguments to counter the President's views on executive power. After explaining responsible parliamentary government, as Aiyar did, he concluded that the 'House of People thus controls the Council of Ministers and through it all the executive power of the Union which is nominally vested in the President'. The Cabinet's legal adviser went on that 'the

\footnotetext{
${ }^{234}$ Prasad to Nehru, 18 September 1951, Prasad: Correspondence and Select Documents, Vol. XIV, p 109

${ }^{235}$ Note by Sir Alladi Krishnaswami Aiyar, 20 September 1951, cited in Prasad: Correspondence and Select Documents, Vol. XIV, pp 280-282
} 
supremacy of the legislature as representing the People would thus appear to be the basic principle of the Constitution' and realising that he was echoing tenets of British Westminster culture argued 'we have in the main adopted the British Parliamentary form of Government with its fundamentals of the supremacy of Parliament and an executive in the form of a Cabinet collectively responsible to Parliament'. ${ }^{236}$

The Attorney-General informed his readers that in his mind there was little doubt, despite the phraseology, that the Head of State was bound to accept the advice of his Ministers and listed similar (if not identical constitutional phrases and practices) instances from the New Westminsters, though only the settler ones, avoiding any mention of the young South Asian Dominions of Pakistan and Ceylon. The AttorneyGeneral cited Section 11 of the British North American Act 1867 which provides that 'there shall be a Council to aid and advise in the government of Canada...'; this similar provision in section 62 of the Commonwealth of Australia Act 1900 states that 'there shall be a Federal Executive Council to advise the Governor-General'; and India's very own colonial precedent Section 9 of the Government of India Act, 1935, which provides that 'there shall be a Council of Ministers...to aid and advise the Governor-General in the exercise of this functions' these replications for the Attorney-General made it 'clear that our Constitution makers have, in framing Article 74, adopted a phraseology well understood and accepted in British constitutional law and history, as imposing on the constitutional head of the executive the obligation to act solely in accordance with the advice of Ministers responsible to Parliament'. ${ }^{237}$ The difference between the British King and the President of India in the Attorney-General's view was not the same as Prasad's creative observation. In fact they could not be more different.

The President under our Constitution has no prerogatives personal or otherwise. In this respect his position as compared to that of the British Monarch is weaker. His functions are to be found in the Constitution: in the exercise of those functions he is, in effect, directed by the Constitution to seek the aid and advice of his Ministers. The fact that the President unlike the King is elected to his office for a term makes no difference to this position. The election is merely a

\footnotetext{
${ }^{236}$ Note by the Attorney-General, 24 September 1951, cited in Prasad: Correspondence and Select Documents, Vol. XIV, pp 282-284

${ }^{237}$ Note by the Attorney-General, 24 September 1951, cited in Prasad: Correspondence and Select Documents, Vol. XIV, p 283
} 
method for the choice of the constitutional executive head. Once he is chosen his functions are as limited and prescribed by the Constitution. ${ }^{238}$

He went on that if the President did feel that he could not assent the Bill this would create a constitutional crisis since 'the refusal to assent would, indeed, be tantamount to dismissal of Ministers' and would 'inevitably lead to the resignation of the Council of Ministers who have the confidence of Parliament'. 239

Both the Attorney-General and Aiyar at no point believed that the President was constitutionally correct. Indeed they were both abundantly clear that Prasad was going against not only Westminster practice but more importantly the very spirit of their own Constitution. Nehru, now abetted with patent legal and political support, replied to Prasad and while acknowledging the President's rights to address and send messages to Parliament and his power to give or withhold assent, he stressed:

These functions have, however, under our Constitution to be performed with the aid and advice of the Ministers. Any action in these fields by the President without the concurrence of his Ministers would be foreign to the entire scheme of our Constitution and indeed render it unworkable. The powers and position of the President in these matters approximate to those of the King under the British Constitution. $^{240}$

Nehru's constitutional diagnosis had differed from Dr Prasad and the Hindu Code Bill illustrated a wider potential for executive conflict when executive actors are not cognisant of constitutional norms. The problem in many ways was as Aiyar noted a few weeks later that 'the President seems to read every Article of the Constitution which the expression "President" occurs as conferring powers upon the President in his individual capacity without reference to the Cabinet'. ${ }^{241}$ Aiyar reminded the Cabinet, most of whom had sat with him in senior positions in the Constituent Assembly, that they had expressly wanted flexibility and sought to avoid creating an American style presidency

\footnotetext{
${ }^{238}$ Note by the Attorney-General, 24 September 1951, cited in Prasad: Correspondence and Select Documents, Vol. XIV, p 285

${ }^{239}$ Note by the Attorney-General, 24 September 1951, cited in Prasad: Correspondence and Select Documents, Vol. XIV, pp 284-286

${ }^{240}$ Nehru to Prasad, 21 September 1951, Prasad: Correspondence and Select Documents, Vol. XIV, p 110

${ }^{241}$ Note by Aiyar, 8 October 1951, Prasad: Correspondence and Select Documents, Vol. XIV, p 287
} 
and that any concession to Prasad on his interpretation of Presidential powers would 'upset the whole constitutional structure envisaged when the Constitution was passed' and 'make the President a kind of dictator answerable to no one and will reduce the Indian Constitution to a hybrid type which has its counterpart neither ... in America nor the Cabinet type of government known to Britain and the Dominions nor to ... France [under the $4^{\text {th }}$ Republic]'. ${ }^{242}$

Aiyar understood that India's Constitution framers wanted a Head of State that was, like the King, above party politics and the symbol of the nation. Looking at Britain he argued that 'the Crown will have to be above party politics and if it exercises the power of dissolution or a power of veto without reference to the Ministry, it cannot but bring itself into the vertex of party politics. This consideration will equally apply to the President under the Indian Constitution' ${ }^{243}$ Referring to Article 111, which stipulates the President's right to 'remit a Bill for reconsideration', Aiyar states that for a President to directly intervene in policy and active politics would be catastrophic and against the axioms of the office since the 'President is not intended to be a revisional or appellate authority over the Cabinet' and the power vested in the President under Article 111 'is as much intended to be exercised on the advice of the Cabinet as any other power. It is not intended to substitute the individual will of the President for the deliberations of Parliament or for the policy underlying a legislation deliberately adopted by the Government'. ${ }^{244}$

Nehru, now with the strength of such opinion pushed his measures through, though he split the Bill, and waited for the democratic endorsement of the electorate with elections just months away, as Prasad had intimated, to pass the full legislative provisions. ${ }^{245}$ With Congress elected to power in 1952 for the first time on a universal adult franchise and gaining 364 out of 489 seats, Prasad could no longer deny the Prime Minister's legitimacy of position on the Bill. Nehru considered the subsequent passing of the legislation 'to be the greatest real advance of his career. ${ }^{246}$ Policy aside, the Prime Minister constitutionally had established ascendancy over the Presidency and negated

\footnotetext{
${ }^{242}$ Note by Aiyar, 8 October 1951, Prasad: Correspondence and Select Documents, Vol. XIV, pp 286287

${ }^{243}$ Note by Aiyar, 8 October 1951, Prasad: Correspondence and Select Documents, Vol. XIV, p 288

${ }^{244}$ Note by Aiyar, 8 October 1951, Prasad: Correspondence and Select Documents, Vol. XIV, p 290

${ }^{245}$ The delay caused Dr Ambedkar, who saw the legislation as vital to reforming India, to resign from the Cabinet. See Som, "Jawaharlal Nehru and the Hindu Code: A Victory of Symbol over Substance", pp 184-188

${ }^{246}$ Brown, Nehru - A Political Life, p 232
} 
any budding horizontal accountability on his powers from Rashtrapati Bhavan. The President lost the prerogative to influence the Prime Minister. Indeed there is evidence that Nehru valued the advice of the Vice-President and distinguished scholar and diplomat Dr. Sarvepalli Radhakrishnan more - though Prasad still had enough influence with the Congress Party to be re-elected in $1957 .^{247}$ Prasad was not a President with authoritarian tendencies. The problem was that he misconstrued the powers given to a Westminster head of state without comprehending the accompanying conventions, or at least comprehended them differently to his Ministers and Westminster precedents. Prasad's motives were not to bring down the Government but to block legislation, which in his mind was highly controversial and damaging to the nation. Indeed, as Austin contends 'Prasad's argument had some moral force'. However:

The point at issue was that he desired to use the power of his office either to force ... Parliament to shelve the measure or, failing that, to veto it even against the advice of his Cabinet. He was willing to endanger the Constitution in pursuit of his own point of view. But more surprising was the way he misread the Constitution, misinterpreting the very evident intent of the Constituent Assembly, in an attempt to prove that he possessed the powers he desired. ${ }^{248}$

Even after the fracas over the Hindu Code Bill the President was still not convinced that he was incorrect. Though he remained President till 1962 and caused little constitutional trouble for the rest of his tenure he still was able to taunt the constitutional equilibrium by telling those assembled at a ceremony in November 1960 to open the Indian Law Institute, 'there is no provision which in so many words lays down that the President shall be bound to act in accordance with the advice of his Council of Ministers'. ${ }^{249}$ Prasad had lost the constitutional battle and by attacking the Government on insecure constitutional grounds rendered a great disservice to the Presidency of India and his successors - especially as a check on Cabinet. The President of India was now rendered more a dignified part of the ceremony of state than an efficient guardian of the constitution and effective proponent of horizontal accountability on the Prime Minister and Cabinet. Indeed Mrs Gandhi, perhaps remembering the hindrance that Prasad had caused her father, sought to eradicate this

\footnotetext{
${ }^{247}$ Sarvepalli Gopal, Radhakrishnan - A Biography, New Delhi: Oxford University Press, 1992, pp $262-$ 266 and 286-292

${ }^{248}$ Austin, The Indian Constitution: Cornerstone of a Nation, $\mathrm{p} 141$

${ }^{249}$ Cited in Basu, Introduction to the Constitution of India, p 188
} 
conundrum surrounding presidential duty to acquiesce to the advice of Cabinet. She attempted to put this convention beyond doubt with the $42^{\text {nd }}$ Amendment to the Constitution in 1976. Article 74 (1) now read:

There shall be a Council of Ministers with the Prime Minister at the head to aid and advise the President who shall, in the exercise of his functions, act in accordance with such advice [author's italics].

The Presidency proved its submissiveness to prime ministerial direction by not even attempting to defend the Constitution against Indira Gandhi's Emergency powers that disabled Indian democracy. The Janata Government that followed after Mrs Gandhi's draconian "Emergency" period removed almost all of Mrs Gandhi's graffiti from the Constitution, but the $42^{\text {nd }}$ Amendment was left unmolested. ${ }^{250}$ Now Presidents were unambiguously obligated to listen to the advice of their Ministers. Now there seemed no hurdle to Aiyar's reminder to the Cabinet: 'In the felicitous language of...Bagehot, the King has no alternative to signing his death warrant if the Parliament chooses to pass a measure in that behalf' ${ }^{251}$ The Indian Presidency would be no different.

Nehru now had overwhelming delegated democratic power since he was without real horizontal accountability and was cursed with an inability to seriously delegate himself due to the impatience of his vision. Nehru now became his own check since by the electoral victory of 1952 he had impressed his interpretations of governance on India and dominated or defeated the executive actors from the President to the Cabinet - and his only rivals for political leadership, Gandhi and especially Patel, had left the political scene permanently. Austin argues that Nehru 'set the tone' as a 'Nation builder, reformer, ardent democrat and flawed administrator', who tried to do everything. At least, however, despite many criticisms and invariable examples of Nehruvian diktat -

The successes of the period were fundamental: power relationships were sorted out constitutionally; the parliamentary system became entrenched, democracy not only survived Nehru's charisma, popular participation strengthened it ...

\footnotetext{
${ }^{250}$ Cited in Basu, Introduction to the Constitution of India, p 189

${ }^{251}$ Note by Aiyar, 20 September 1951, cited in Prasad: Correspondence and Select Documents, Vol. XIV, p 282
} 
This was no golden age, but the Nehru years set standards against which others would be measured - and many fall short. ${ }^{252}$

${ }^{252}$ Austin, Working a Democratic Constitution, pp 36-37 


\section{Federalism: A Paramount Mechanism}

'It seems doubtful whether India could have avoided it' was Sir Ivor Jennings parsimonious admission on India's federal structure before adding the real assessment that it is 'not easy to seise [sic] the essential characteristics of Indian federalism'. ${ }^{253}$ India's federal system is unquestionably distinctive, which was not entirely appreciated at the time due to the organic and multi-dimensional constitutional inheritance from the colonial period and the critical crises that faced British India and independent India, which will be discussed further below. India's experience with federalism in the colonial period and especially after was in reality a calculated, but essential risk to answer the needs and dilemmas of cajoling, containing and coordinating a vast subcontinent. This gamble was one that continues to impact on India's polity. India's first ten years of independence were a critical juncture period with the establishment of federalism being prominent. India's federal experience differed greatly from that of the settler-based United States of America with its foundation in largely homogeneous ethnic circumstances and jealous guarding of individual states' powers or similarly the Canadian and Australian Commonwealth of colonial States or even the multi-linguistic Swiss canton system buttressed by referenda. ${ }^{254}$ Though not often attributed to the New Westminsters, some form of federalism is a feature to almost all the major cases such as Canada, Australia, South Africa and of course India despite the fact that 'English political tradition looked with disfavour' at stipulated federal elements in constitutions. $^{255}$

Constitutional scholars like Sir Kenneth Wheare described India as 'quasi- federal' since from a mechanical perspective the Centre had considerable powers of intervention in the affairs of State governments and therefore is more a unitary state with subsidiary features of federalism. ${ }^{256}$ As Brass asserts 'though India is both a sub-continental state and the most culturally diverse country in the world today, the federal system adopted

\footnotetext{
${ }^{253}$ Sir Ivor Jennings, Some Characteristics of the Indian Constitution - Being Lectures given in the University of Madras during March 1952 under the Sir Alladi Krishnaswami Aiyer Shashtiabdapoorthi Endowment, Madras: Cambridge University Press, 1953, p 55

${ }^{254}$ Jyotirindra Dasgupta, "India's Federal Design and Multicultural National Construction" in The Success of India's Democracy, pp 54-55 and Alexandrowicz, Constitutional Developments in India, p 155

${ }^{255}$ Ian Copland and John Rickard, "Introduction", in Federalism - Comparative Perspectives form India and Australia, Ian Copland and John Rickard (eds.), New Delhi: Manohar, 1999, p 18

${ }^{256}$ K. C. Wheare, Federal Government, $3^{\text {rd }}$ edition, London: Oxford University Press, 1956, p 28
} 
has had from the beginning more unitary features than most other large federal systems, more notably that of the United States'. ${ }^{257}$ However, India's political structure cannot be judged purely from a theoretical or constitutional perspective and though Wheare and others have illuminated mechanical differences, they have generally not emphasised the critical juncture of exceptional circumstances that moulded federal principles to adapt to the Indian environment. India's formation must be adjudicated by the contexts, conditions and culture (colonial and indigenous) that pressed upon the Constituent Assembly's outcomes, which created a thoroughly unique polity. India's 'bold experiment of combining democratic responsiveness to cultural differences with a federal conciliation of regional community, identity, and autonomy claims and a nationally concerted promotion of regional capability, has tendered to ensure a novel mode of multicultural development'. ${ }^{258}$ As Austin argues, India's leaders were confronted with problems that they believed had not been encountered before by other federations in history and that the Constituent Assembly in fact 'produced a new kind of federalism to meet India's peculiar needs'. ${ }^{259}$

This chapter does not seek to explain the almost exhaustless provisions, articles and amendments of India's Federal Union, but it does attempt to examine the key characteristics of India's federalism that demarcate it from others and more importantly continue to have path dependent impressions on India. These key federal characteristics are i) its distinctive origins from Partition and the Princely States ii) the Centre's constitutional powers over the periphery and iii) its early accommodation of linguistic, ethnic and sectarian elements in first ten years especially through the States Reorganisation recommendations. Despite many early predictions of India's demise due to its massive divisions, the Indian state endures. ${ }^{260}$ This period was crucial for India's endurance especially as it contained critical junctures for State formation like Partition, which would have not only an immediate social and political effect on the boundaries and social composition of India, but also through its impact on the counsels of the Constituent Assembly, which created a long-term effect making it culturally favourable to implement powerful constitutional provisions regarding emergency and central powers as well as India's critical form of federalism.

\footnotetext{
${ }^{257}$ Brass, The Politics of India since Independence, $\mathrm{p} 65$

${ }^{258}$ Dasgupta, "India's Federal Design and Multicultural National Construction", p 49

${ }^{259}$ Austin, The Indian Constitution, p 186

${ }^{260}$ For example see Selig Harrison, India, The Most Dangerous Decades, Madras: Oxford University Press, 1960
} 
As one of the leading scholars on India's pluralistic polity, Jyotirindra Dasgupta, argues, India's 'political prudence, legal flexibility, institutional inclusion, and interactive opportunities incorporated in the federal design can account for an important measure of the durability of Indian federalism'. ${ }^{261}$ The above identifications are largely features that are generally associated with Westminster systems. As Jalal states, India's vastness may prompt the conclusion that the country's 'need for a federal system was more an imperative than a matter of political choice', but this neglects the historic contentions over what federalism was and for whom would it represent and where power would lie. $^{262}$ The genesis of Indian federalism is its peerless feature. The federalism that was established formally within the first ten years of independence was the product of critical and often neglected circumstances that are crucial as a path dependent feature to comprehend modern India's ability to survive and strive today.

\section{Princes and Partition - The Inimitable Origins and Formation of the Indian Federalism}

Over fifty years later the trauma and memories of India's Partition still fuels heated political, historiographical, social and emotional debate in India, Pakistan and beyond. $^{263}$ A reading of the voluminous literature on Partition, which is an academic genre in its own right, would give the impression that the reasoning, impetus and form of India's federalism was crafted entirely with Partition in mind. This is not entirely accurate. As Ian Copland argues 'Historians of colonial India have generally glossed over the long and complicated saga of all-India federation: partly one suspects, because it was long and complicated, but also because ... this grandest of imperial projects had finally to be abandoned' ${ }^{264}$ As was discussed in chapter two the Constituent Assembly were heavily and naturally moulded by the chaotic, violent and unstable atmosphere that the division of the Indian Empire bequeathed, however the ideas of federalism emerged much earlier from a most unlikely and neglected corner - the Indian Princes.

\footnotetext{
${ }^{261}$ Dasgupta, "India's Federal Design and Multicultural National Construction”, p 50

${ }^{262}$ Jalal, Democracy and Authoritarianism in South Asia - A Comparative and Historical Perspective, $\mathrm{p}$ 161

${ }^{263}$ For an overview see for example Sucheta Mahajan, Independence and Partition - The Erosion of Colonial Power in India, New Delhi: Sage Publications, 2000; Mushirul Hasan, "Memories of a Fragmented Nation: Rewriting the Histories of India's Partition" in The Partition in Retrospect, Amrik Singh (ed.), New Delhi: Anamika Publishers, 2000, pp 339-360; Ayesha Jalal, "Secularists, Subalterns and the Stigma of Communalism: Partition Historiography Revisited", Modern Asian Studies, Vol. 30, No. 3, July 1996, pp 681-689 and A. Roy, “The High Politics of India's Partition: The Revisionist Perspective", Modern Asian Studies, Vol. 24, No. 2, 1990, pp 385-415

${ }^{264}$ Ian Copland, The Princes of India in the Endgame of Empire, Cambridge: Cambridge University Press, 1997, p 73
} 
The Crown had always had special sway over Indian opinion, at least since Victoria's proclamation welcoming Indians as equal subjects of the British Empire, which even inspired Gandhi. ${ }^{265}$ George V, their sovereign-liege, was especially keen to affirm this pledge to his greatest possession. The King had visited India during his Royal durbar in December 1911 and wanted to provide some indication of his good-will to his Indian subjects. The visit coincided with a Liberal Government in London. Months later the progressive Viceroy, Lord Hardinge, supported by the Secretary of State for India, Lord Crewe, wanted more 'devolution of power' by giving the Provinces a 'larger measure of self-government'. To Curzon, an upholder of centralised power, the proposals, as he decried in the Lords, amounted to a 'picture of federation or self-governing and quasiindependent States', of which he certainly did not approve. ${ }^{266}$ Much of Hardinge's proposals and the King's enthusiasm were to do with their concern for the Indian Princes.

Modern studies of India have seldom given serious attention yo, let alone focus on, the Princely order and their kingdoms except as Kiplingesque footnotes on the ostentation and eccentricity of Indian Royalty. This is despite the fact that the Princely States occupied in pre-1947 India two-fifths of the area and one-third of the population and contained States like Kashmir, which was bigger than France and Hyderabad whose income and expenditure in 1947-48 rivalled Belgium's. ${ }^{267}$ The Princely States' contribution to India either directly or by reaction had a major effect on the formation of the Indian Union. It easy to forget that Britain held much of India through indirect rule over much of India through the concept of British Paramountcy (the Crown's supremacy over the Princely States), which enabled the Viceroy to establish Residents in the Princely States to ensure the Empire's requirements were met and the Princes gave their allegiance to the paramount power in return for measured local autonomy.

Before the hegemony of Congress in the late 1930s the Indian Princes were a formidable power in terms of their influence and importance in dealing with the British. Especially after World War I where the Indian Princes had contributed men and money (and leadership, sometimes leading their brigades in Europe and the Middle East for the British side while the Maharajah of Bikaner even sat in the Lloyd George War Cabinet).

\footnotetext{
${ }^{265}$ Gandhi himself was the son of the Dewan of Porbandar and as a young lawyer was highly enthusiastic over Queen Victoria's 1858 proclamation. See M. B. Steger, Gandhi's Dilemma: Non-violent Principles and Nationalist Power, New York: St Martin's Press, 2000, pp 41-66

${ }^{266}$ R. J. Moore, Liberalism and Indian Politics 1872-1922, London: Edward Arnold, 1966, pp 101-105

${ }^{267}$ Copland, The Princes of India in the Endgame of Empire, pp 1-15
} 
In response to such outpouring of patriotism to their sovereign-liege, George $\mathrm{V}$, who had met most of the Indian potentates at his Royal durbar, sent in 1921 his brother the Duke of Connaught to establish in person one of the most unique legislative chambers in the colonial world: the Chamber of Princes. As a result of the Montagu-Chelmsford reforms of 1919 the 120 member Chamber of Princes was inaugurated as an advisory body composed of the senior princes (108 Princes with a salute of eleven guns or more and twelve other Princes to represent the smaller States) and elected their own Chancellor - though the Viceroy was the presiding officer as the Crown Representative. $^{268}$

The importance of this aristocratic trade union constitutionally was that it was the forum for the Princes and their Dewans (Chief Ministers) to advocate their importance and protect their position. One of the ways which they sought to do this was through the idea of federation with all of India, which they argued for in the late 1920s and early 1930s. They believed this would secure their autonomy by breaking the manacles of paramountcy and even enhance their reputation by propagating reform, which they did to a degree at the London Round Table Conference on India in 1930; their voices more authoritative on sympathetic ears like Prime Minister Ramsay Macdonald and Conservatives like Stanley Baldwin and Sir Samuel Hoare since Gandhi and Congress did not attend. ${ }^{269}$ However, the capricious Princes themselves began to have doubts since many believed that joining formally with British India would spread the contagion of democracy to their own feudal outposts as well as concern over their financial and military independence not to mention having to work with an avowedly Republican Congress.

In practical terms over 500 Princes used to having their own way struggled to create cohesion and unity of position, but nonetheless the position was crucial for the future of India. The rise of Gandhi and Congress meant that the Princes' eminence was weakened and in relentless decline, as Congress dominated the social leadership of India and became the constitutional channel with the British. Nehru, Congress and Mountbatten at that final lap of Empire were concerned about the "Balkanisation" of India if, as predicted, the States declared independence when the Raj ended or even their

\footnotetext{
${ }^{268}$ For further detail see William L. Richter and Barbara N. Ramusack, "The Chamber and the Consultation: Changing Forms of Princely Association in India", The Journal of Asian Studies, Vol. 34, No. 3, May 1975, pp 755-776

${ }^{269}$ Barbara N. Ramusack, The Indian Princes and their States, Cambridge: Cambridge University Press, 2004, pp 245-252
} 
loose idea of federation, which would generate, in their minds, a nightmarish spectre of nebulous and discordant autonomy rendering India centrally ungovernable. To Nehru's consternation, large states like Hyderabad, Bhopal and Travancore seriously contemplated becoming separate Dominions, which was a serious possibility especially since a state like Hyderabad had its own army and a population larger than any of the existing Dominions. Mountbatten, with his Royal charm, was able to convince the Monarchs that he could only transfer power to two Dominions: India and Pakistan. ${ }^{270}$

One of the key reasons the Indian States were contemplating independence was because Nehru, Patel and Congress rejected the loose all-India federation proposed and instead wished to inherit paramountcy from the British and compel the States to join India. Mountbatten, with the gravitas of a blue-blood, assured his regally kindred Maharajas that paramountcy would lapse with Britain's departure. The collapse of British power, civil unrest, communal violence, and the lack of serious alternatives and the serious pressure from Attlee to Jinnah compelled the Princes to reluctantly sign Instruments of Accession, which merged them with the new Dominions of India and Pakistan and continued the administrative arrangements that had existed with the British, though many empathised with the Dewan of Indore who exclaimed that he now knew what Dollfuss felt like when he was sent for to see Hitler'. 271

In return the Princes were guaranteed amongst other things a generous Privy Purse from the Government of India in perpetuity, free medical care, free electricity, the right to a military escort and the retention of their titles and in addition many were translated into the new order by becoming Rajpramukhs and Uprajamukhs (Governors and LieutenantGovernors) of the new States - often their old one. ${ }^{272}$ At 15 August 1947 with only three of the 562 States claims not acceded (two were major however: Hyderabad examined above which joined India though military intervention in 1948 and the quagmire of Kashmir) and Lord Listowel, Secretary of State for India, could rightly

\footnotetext{
${ }^{270}$ R. J. Moore, Escape from Empire - The Attlee Government and the Indian Problem, Oxford: Oxford University Press, 1983, pp 303-308

${ }^{271}$ Ramusack, The Indian Princes and their States, p 273; Copland, The Princes of India in the Endgame of Empire, p 258 and see V. P. Menon, The Story of the Integration of the Indian States, Calcutta: Orient Longmans, 1956 for a detailed story of individual agreements with the States from a Government of India perspective [Menon was the Civil Servant in charge of the States Ministry with Patel as Minister]. ${ }^{272}$ Copland, The Princes of India in the Endgame of Empire, pp 265-266 and William L. Richter, "Traditional Rulers in Post-Traditional Societies: The Princes of India and Pakistan" in People, Princes and Paramount Power - Society and Politics in the Indian Princely States, Robin Jeffrey (ed.), Delhi: Oxford University Press, 1978, pp 329-354. Mrs. Gandhi actually abolished the Privy Purse and many of the other privileges in 1971.
} 
claim that the success and the appeasement of accession had saved India from 'unimaginable disaster'. ${ }^{273}$

However, within months of the transfer of power, Patel, with the full authority of the Cabinet 'succeeded in imposing the Centre as a paramount power over the States'. 274 Indeed as a forerunner of President's rule the new Government re-established Resident's rule though renamed as Regional Commissioners - these civil servants imposed the New Raj's doctrines immediately on its constituent units just as its predecessor had done. For instance it imposed rules on Bharatpur, took direct control of Cutch and Manipur, forced the Maharajah of Alwar to step down whilst they investigated his alleged connection with Gandhi's assassin and even told the Maharajah of Jodhpur to cut down on his consumption of whisky and women. ${ }^{275}$ Nehru had always attacked any contemplation of a lapse in paramountcy since he saw it as integral to maintaining the integrity of India. Nehru and Congress believed that anything other than Paramountcy would catalyse the disintegration of India and as Rajagopalachari told Sir Stafford Cripps: 'Paramountcy came into being as a fact and not by agreement, and on Britain's withdrawal the successor authorities must inherit the fact along with the rest of the context'. ${ }^{276}$ The Princes had accepted, with their unwavering faith in the monarchical system, the words of the King's Representative and yet the new 'Indian Government virtually re-created for itself the powers of paramountcy without its obligations'. 277

The legacy of paramountcy enabled a strong Centre at the head of the States. It is interesting to speculate if the Princes had been more united and pressed for their version of federalism i.e. a loose federation of autonomous states with a weak centre. Copland hypothesises that if the Princes' plan was established when they had the influence in the 1930s, before serious communal disturbances, India could have been a different place. Aside from a having real power centred in the constituent parts, the Muslims might not have clamoured for Pakistan and the bloody Partition might have been evaded, since their interests may have been met by a strong provincial state system. ${ }^{278}$ Speculation

\footnotetext{
${ }^{273}$ Moore, Escape from Empire - The Attlee Government and the Indian Problem, p 313

${ }^{274}$ James Manor, "The Demise of the Princely Order: A Reassessment" in People, Princes and Paramount Power - Society and Politics in the Indian Princely States, p 322

${ }^{275}$ Copland, The Princes of India in the Endgame of Empire, p 261

${ }^{276}$ Moore, Escape from Empire - The Attlee Government and the Indian Problem, pp 298-303

${ }^{277}$ H. V. Hodson, The Great Divide - Britain - India - Pakistan, London: Hutchinson, 1969, p 502

${ }^{278}$ Copland, The Princes of India in the Endgame of Empire, p 284-285 and see footnote 50
} 
apart, India consciously inherited the centralised machinery of state from the British and in their belief required it to maintain India in the wake of communal war and division that surrounded Partition and gave yet another and even more powerful reason for a centrally focussed, though still federal, India.

One of the rationalisations that Congress 'coveted the strong central authority of the colonial state was to quickly snuff out any reassertion of the centrifugal tendencies' that occurred during the last days of British rule. As Jalal reasons, the 'anguish of partition ... provided the managers of post-independent India with powerful legitimisation to curb autonomists' ${ }^{279}$ Partition was a powerful social context that figured prominently in the minds of the British and their successors and the political structure they crafted must inevitably be measured by those terrific experiences. The process of Partition was 'not a simple geographical bifurcation of Indian territory but a painful surgical operation that entailed unimaginable human suffering and large-scale migration on both sides of the border'. ${ }^{280}$ The scope of this thesis does not extend to the social details of this tragic and colossal communal catastrophe that affected millions of people and provided a birth of explosive violence to India and Pakistan. The focus on Partition is narrowed substantially to assess its constitutional impact as a critical juncture on India as a path dependent trait. Gyanendra Pandey, a leading scholar on Partition, identifies three conceptions of Partition. The 'first partition' is concerned with the demand and subsequent creation of Pakistan; the 'second partition' examines the division of Bengal and Punjab and the 'third partition' focuses on the social and migratory elements of this great upheaval. ${ }^{281}$ For the purposes of this thesis and its constitutional premise the "first partition' is where the analysis will be centred due to the federal and constitutional outcomes there were generated by the creation of Pakistan and its Muslim basis.

There is a long history of Muslim agitation for separate and special recognition in India, especially during the hegemony of the Islamic Mughal Empire over the subcontinent. However, the idea of Pakistan itself, the proposal for a partition of British India between its Muslim-majority and its Hindu-majority provinces, had not had a long history' since it began only in early $1940 .^{282}$ The reasons behind Pakistan and the

\footnotetext{
${ }^{279}$ Jalal, Democracy and Authoritarianism in South Asia - A Comparative and Historical Perspective, $\mathrm{p}$ 161

${ }^{280}$ K. L. Tuteja, "Hindu Consciousness, the Congress and Partition" in The Partition in Retrospect, p 3

${ }^{281}$ Gyanendra Pandey, Remembering Partition - Violence, Nationalism and History in India, Cambridge: Cambridge University Press, 2001, pp 21-44

${ }^{282}$ Pandey, Remembering Partition - Violence, Nationalism and History in India, p 21
} 
personalities of Jinnah, Nehru and Mountbatten that dominated the discourse are still subject to controversy and polemics. Some eminent historians see Pakistan as a Jinnah bargaining ploy to wrench concessions from the British and Congress ${ }^{283}$, while on the other side certain historians believe that Jinnah was only demanding equity and his hopes for an all-India Union were stymied by Congress intransigence, which along with British abandonment and lack of protection led to the inevitability of Pakistan. ${ }^{284}$ The debates do not greatly concern this thesis for it is the prospect of Pakistan or at least Muslim federated areas and later the advent of the separate Dominion of Pakistan which influenced the thinking and form of the independent Indian State. At least since the March 1940 Lahore Declaration did the threat of Pakistan become publicly disseminated. The All India Muslim League passed a resolution in answer to the demand for an articulation of the Muslim League's objectives to constitutional settlement. The "Pakistan resolution" stated

that no constitutional plan would be workable in this country or acceptable to the Muslims unless it is designed on the following basic principles, viz., that geographical contiguous units are demarcated into regions which should be so constituted, with such territorial adjustments as may be necessary, that the areas in which the Muslims are numerically in a majority, as in the North-Western and Eastern zones in India, should be grouped to constitute "Independent States" in which the constituent units will be autonomous and sovereign. ${ }^{285}$

The "Pakistan resolution" was a dramatic one and "proved to be a turning point in Indian history'. ${ }^{286}$ Whatever the historiography and contentions over the exact meaning and intention of the resolution it cannot be denied that it publicly promulgated the idea to the British, Congress and Muslims themselves of "independent", "autonomous" and "sovereign" Muslim areas. This was well beyond the gentle regional government offered by the Government of India Act 1935. Some scholars argue that the Congress successes in 1937 provincial elections that followed the Act made Jinnah 'feel inclined towards the idea of a separate, sovereign Muslim state'. ${ }^{287}$

\footnotetext{
${ }^{283}$ One of the key texts with this argument is Ayesha Jalal, The Sole Spokesman - Jinnah, the Muslim League and the Demand for Pakistan, Cambridge University Press, 1985

${ }^{284}$ For example Saeed R. Khairi, Jinnah Reinterpreted: The Journey from Indian Nationalism to Muslim Statehood, Karachi: Oxford University Press, 1995

${ }^{285}$ D. N. Panigrahi, India's Partition - The Story of Imperialism in Retreat, Oxford: Routledge, 2004, p 152

${ }^{286}$ Panigrahi, India's Partition - The Story of Imperialism in Retreat, $\mathrm{p} 152$

${ }^{287}$ Bimal Prasad, "Jawaharlal Nehru and Partition" in The Partition in Retrospect, p 38
} 
It is easy to forget that it was only in June 1947, just ten weeks before Independence Day that the formal constitutional partition of India was decided. Fundamentally the real issue of contention between Congress and the Muslim League was the categorical refusal of Gandhi, Nehru and Congress to accept Jinnah's proposition that the League represented all Muslims while Jinnah refused anything but parity of status with Congress, who he argued only represented Hindus and Hindustan, and wanted, amongst other things, to have a separate Constituent Assembly to recognise Jinnah's "twonation" theory. ${ }^{288}$ The elections of early 1946 further aggravated the political divisions and accentuated the constitutional stands. Congress secured ninety-one per cent of the votes cast in general constituencies while the Muslim League gained eighty-six per cent of the votes in the Muslim constituencies. ${ }^{289}$

The results were seen as a plebiscite for Pakistan and the League could claim legitimacy as the premier, if not sole, representative of Muslim interests while Congress's successes showed its dominance over the general population i.e. the non-Muslim parts. Later that year, with the results fresh in the Indian consciousness, the new Labour Government in Britain sent a Cabinet Mission to create the mechanics of withdrawal. The Cabinet Mission advocated a 'loose-federation' with the two major Muslim areas (in the north-west and north-east) being two of the federation units while the rest of India formed the third. However, the proposals to maintain a united India collapsed due to both Congress and the Muslim League having suspicions of the other, especially Congress being concerned over a loose federation where the League would have command over two of the federal units, which would encumber its influence and constitutional ascendancy. ${ }^{290}$ Once again Congress, as with the Princes, was concerned about the potential dilution of central power by any disbursement of control to regional authorities.

The Interim Government, as discussed above, which was constituted following the 1946 elections, lacked any sense or purpose of unity as long as Congress and the Muslim League were compelled to fight for space at the Viceroy's Executive Council table. Perhaps for such reasons, as well as the intransigence of Jinnah and the engulfment of communal violence, Nehru and Congress were able to admit and accept the prospect of

\footnotetext{
${ }^{288}$ Panigrahi, India's Partition - The Story of Imperialism in Retreat, pp 151-155 and pp 273-279

${ }^{289}$ Panigrahi, India's Partition - The Story of Imperialism in Retreat, $\mathrm{p} 271$

${ }^{290}$ Pandey, Remembering Partition - Violence, Nationalism and History in India, pp 22-23
} 
Partition soon after Mountbatten's arrival in March 1947. ${ }^{291}$ Nehru and Congress have been blamed for not preventing Partition, still a painful laceration on the Indian body politic. However as Bimal Prasad argues, if Partition had not been accepted -

there was the danger that the British and the League's bargaining strategies might result not only in one Partition, but open the flood-gates for several partitions in the future by providing for an extremely weak centre and secession at will of a unit of the federation ... Nehru's effort was directed towards preventing that eventuality and making clear the determination of the Congress to oppose it ... Thus while Nehru, pitted against powerful historical and social forces, failed to prevent India's Partition in 1947, he succeeded, of course with the help of the same forces, in scotching the move for sowing the seeds of the endless Balkanisation of India... ${ }^{292}$

Nehru vehemently would not allow the lapse of paramountcy but appeased the operation of Partition - perhaps for different reasons but the same result. The virtual and willing inheritance of paramountcy coupled with the constitutional catharsis that Partition generated allowed the Constituent Assembly to create a federal structure with a strong centre, which could never have been possible without the critical juncture and sequence of events that resulted from the Princes and Partition. To understand the machinery of state and constitutional provisions that allowed for centralised power over the Indian Union such a backdrop is crucial.

\section{New Delhi's Dominance - Central and Emergency Powers over the Indian Union}

The British constitutional legacy was not confined to decaying volumes of Dicey at Delhi Library. It also more conspicuously impressed itself in the form of centralised power that had been the hallmark of viceregal rule, even with the introduction of the semi-federal 1935 constitution. As well as the apparatuses of state the 'spirit' of power remained as Weiner states 'the viceregal model is thus just as much a part of the British tradition as the Westminster model'. ${ }^{293}$ India accepted this retention of British colonial culture. Contemporary constitutional scholar, K. Santhanam, usefully analysed just over a decade after independence that India's was 'a Federation in which the

\footnotetext{
${ }^{291}$ Moore, Escape from Empire - The Attlee Government and the Indian Problem, pp 237-247

${ }^{292}$ Prasad, "Jawaharlal Nehru and Partition", p 44

${ }^{293}$ Myron Weiner, The Indian Paradox - Essays in Indian Politics, Ashutosh Varshney (ed.), New Delhi: Sage Publications, 1989, p 81
} 
Paramountcy powers which the British Government had over the Indian [Princely] States have been taken over by the Union Government and applied to all its units ... so, it will be appropriate to call our Federation a "Paramountcy Federation". ${ }^{294}$ As was argued above the propinquity of Partition with the amalgamation of incongruous Princely States weighed heavily on the decisions of the constitutional framers in the Constituent Assembly and pushed them towards a flexible and centralised federal framework.

The accomplishment of both tasks did not remove the fear of the disintegration of the new state. Eliminating the proposal to use the term "the Federation of India" Ambedkar explained this to the Assembly that "Union" would be used instead of "Federation" to 'make it clear that though India was to be a federation, the federation was not the result of an agreement by the states [not just the Princely ones] to join in a federation, and that the federation not being the result of an agreement no State has the right to secede from it'. ${ }^{295}$ Ambedkar stressed in November 1948 with clarity of intention that 'what is important is that the use of the word "union" is deliberate ... because it is indestructible'. ${ }^{296}$ Unlike the relatively autonomous states that were represented in Philadelphia there was to be no United States of India. The States had not ceded qualified powers to a central authority as in America. Sovereignty and control was taken directly from the centralised colonial power and then devolved by degree from Delhi to the outlying units with parsimony especially since the nature and boundaries of these regional units were as yet uncertain coupled with the cumbersome integration of the Princely States. The Indian Union operated as one observer describes as 'prefectorial federalism' such as with the appointment of State Governors directly by the Centre as agents of the Centre. ${ }^{297}$

Drawing from the Australian, Canadian and Government of India 1935 Act experiences the Indian Constitution's seventh schedule established three lists of powers and responsibilities: the Union List, the State List and the Concurrent List. The Union List, the longest, includes usual central powers of defence, trade, currency and foreign

\footnotetext{
${ }^{294}$ K. Santhanam, Union-State Relations in India, London: Asia Publishing House, 1960, p 13

${ }^{295}$ Cited in Dasgupta, "India's Federal Design and Multicultural National Construction", p 56. In fact to make it especially clear that there was no right of secession, the $16^{\text {th }}$ Amendment, passed while Nehru was still Prime Minister in 1963 made it 'clear that even advocacy of secession will not have the protection of the freedom of expression'. In Basu, Introduction to the Constitution of India, pp 55-56 ${ }^{296}$ Cited in H. M. Rajashekara, "The Nature of Indian Federalism: A Critique", Asian Survey, Vol. 37, No. 3, March 1997, p 246

${ }^{297}$ Rajashekara, "The Nature of Indian Federalism: A Critique”, p 252
} 
affairs. The State List covers powers relating to issues such as agriculture and sanitation. The Concurrent List has powers which can be exercised by both the Union and the States, 'but when they conflict the former will prevail'. ${ }^{298}$ This ability of the Centre to "prevail" over the rest is not unusual. As Austin argues 'Central governments in all federations have means to make their will felt in the capitals of the country's constituent units'. However this 'will' is 'unusually extensive in India' because of at least four factors: 'the country's initial top-down federalism, anxieties about national unity and integrity, the policies, strategies, and machinery for economic and social development, and the desires of political parties and individuals to exert power nationally. 299

Nehru was judicious on constitutional procedures and unquestionably diligent to include and inform the Chief Ministers of the policies and expectations of the Centre, seeing them as vital interlocutors of his vision to the masses. ${ }^{300}$ However, Nehru was very much a centraliser by personality, a characteristic he shared crucially with the Minister of States - Patel. Nehru was fortunate that in his years as Prime Minister the Congress held sway in the Centre and the States, and importantly the Governors and Chief Ministers of these States were often trusted allies who shared Nehru's national views on unity. The peculiar and extraordinary circumstances of India's beginnings in a period of communal violence, critical economic problems and grave uncertainty propelled those in the Constituent Assembly to entrust power to the Centre with an impatient visionary in Nehru at the helm. ${ }^{301}$ It cannot be ignored that the 'Nehru years institutionalised centralisation' with the Prime Minister as the 'national nanny'. ${ }^{302}$

Perhaps the most controversial element of the Constitution is Part XVIII under Articles 352-360 - the Emergency Provisions. Though the most controversial and prominent deployment of these powers happened after the first ten years of independence they are still vital to assess executive and central power. The controversy of these powers arises

\footnotetext{
${ }^{298}$ Pylee, Constitutional Government in India, pp 625-629; Krishna K. Tummala, “The Indian Union and Emergency Powers", International Political Science Review, Vol. 17, No. 4, October 1996, p 374 and Basu, Constitutional Law of India, pp 527-551

299 Austin, Working a Democratic Constitution, p 594

${ }^{300}$ See Morris-Jones, "Shaping the Post-Imperial State: Nehru's letters to Chief Ministers", pp 223-226

${ }^{301}$ An example of passing the responsibility back to the Centre is the ability of State Governors to "reserve" bills from the State Legislature for the President's consideration whose assent would be necessary to become law. Rather than a sparsely used provision President Prasad dismissively noted that during the years 1953-56, 1,114 of the 2,557 laws enacted by State Legislatures had come to him for consideration. See Austin, Working a Democratic Constitution, pp 590-591.

${ }^{302}$ Austin, Working a Democratic Constitution, p 565
} 
since many, like notable scholar Henry C. Hart, are of the view that 'the fundamental law of India does, in fact, provide for constitutional dictatorship. It does so, manifestly, through its Emergency clauses'. ${ }^{303}$ One of the contrasts with other federal New Westminsters is India's explicit and 'comprehensive set of provisions relating to emergency powers'. ${ }^{304}$ Article 352 addresses the ability of the Indian State to free itself from constitutional shackles and defend the country in times of war. Article 355 gives the right of the Centre to protect every State against internal disturbance and external aggression. ${ }^{305}$ The most constitutionally crucial in terms of the Centre's power over the Union is the maligned Article 356.

This gives the Union Cabinet, through the President, the power to declare an emergency and dismiss the elected State Government on receipt of the State Governor's report, which should "satisfy" the President that the normal constitutional processes have broken down. Known as "President's Rule", Article 356 enables the Centre to assume full executive power and the power to legislate on any subject even on the State List and even includes provisions for 'suspending in whole or in part the operations of any provisions of this Constitution relating to any body or authority in the State' (except those pertaining to the High Court), which can be read with Article 365 that allows the Union to invoke the above emergency powers on the controversial, but blunt, grounds 'where any State has failed to comply with, or to give effect to, any directions given in the exercise of the executive power of the Union'. ${ }^{306}$ To emphasise these unique Central unitary powers Ambedkar told the Assembly in November 1948:

All federal systems including the American are placed in a tight mould of federalism. No matter the circumstances, it cannot change its form and shape. It can never be unitary. On the other hand the Draft Constitution (of India) can be both unitary as well as a federal according to the requirements of time and circumstances. In normal times, it is framed to work as a federal system. But in times of war it so designed as to make it work as though it was a unitary system.

\footnotetext{
${ }^{303}$ Hart, "The Indian Constitution: Political Development and Decay", p 431 and Alan Geldhill who produces the vision of an authoritarian government being created without violating the Constitution in Alan Gledhill, The Republic of India: The Development of its Laws and Constitution, London: Stevens and Sons, 1951

${ }^{304}$ H. P. Lee, "Emergency Powers in Australian and Indian Federalism" in Federalism - Comparative Perspectives form India and Australia, $\mathrm{p} 18$

${ }^{305}$ Basu, Constitutional Law of India, pp 441-455 and Tummala, "The Indian Union and Emergency Powers", p 377

${ }^{306}$ Article 356 and Article 365 in Basu, Constitutional Law of India, pp 445-457, 460
} 
Once the President issues a Proclamation ... the whole scene can become transformed and the State becomes a unitary State ... Such a power of converting itself into a unitary State no federation possesses. This is one point of difference between the Federation proposed in the Draft Constitution and all the other Federations we know of. ${ }^{307}$

Some scholars have compared such emergency provisions to Article 48 in the Weimar Constitution which allowed Chancellor Hitler, through President Von Hindenburg's acquiescent signature, the extraordinary powers to build a totalitarian state. ${ }^{308}$ To Ambedkar however the emergency provisions would be there only for the gravest emergency such as the menacing threat of invasion from Pakistan. Ambedkar consoled the Constituent Assembly that with the Emergency provisions and their powers to override the States that 'the proper thing we ought to expect is that such Articles will never be called into operation and that they would remain a dead letter'. ${ }^{309}$ Perhaps Ambedkar was thinking of the flexible and potential powers of the Crown to deal with emergencies though curmudgeonly utilised in the rarest instances. However, these emergency powers were more often exposed than hidden. In the first fifty years of independence President's Rule under Article 356 was activated over a hundred times. ${ }^{310}$ The Sarkaria Commission reported in 1988 that in examining seventy-five cases of the use of Article 356 only twenty-six were 'inevitable' while the rest had politically abused the provision of President's Rule. ${ }^{311}$ One former Supreme Court Judge described Article 356 as method of 'constitutional terrorism'. 312

In the first ten years President's Rule was instigated four times. ${ }^{313}$ Though relatively small compared to subsequent eras the first application of President's Rule in Punjab in 1951 reeked of controversy and became a dangerous and lasting precedent of Central interference in troublesome States. The Punjabi Chief Minister, Gopichand Bhargava,

\footnotetext{
${ }^{307}$ Cited in Shiva Rao, The Framing of India's Constitution - A Study, pp 810-811. Article 352 was utilised with popular consent in 1962 to deal with the Chinese border invasion and 1971 to deal with Pakistan and the conflict over West Pakistan (Bangladesh).

${ }^{308}$ Michael Henderson, "Setting India's Democratic House in Order: Constitutional Amendments", Asian Survey, Vol. 19, No. 10, October 1979, p 947

${ }^{309}$ Cited in Pylee, Constitutional Government in India, p 698

${ }^{310}$ See Table XXI in Basu, Introduction to the Constitution of India, pp 471-473

${ }^{311}$ Dasgupta, "India's Federal Design and Multicultural National Construction", p 64-65. For a more detailed analysis of the utilisation of President's Rule see Bhagwan D. Dua, Presidential Rule in India 1950-1984: A Study in Crisis Politics, New Delhi: S. Chand \& Company, 1985

${ }^{312}$ Rajashekara, "The Nature of Indian Federalism: A Critique”, p 250

${ }^{313}$ In the Punjab, 1951; PEPSU (Patiala and East Punjab States Union), 1952; Andhra, 1954 and

Travancore-Cochin, 1956
} 
was at odds with the Congress High Command over his administration of the State and Nehru and other Congressmen believed he was not handling well the sectarian tensions in this key State and were unhappy with the composition of his State cabinet. ${ }^{314}$ Bhargava, though enjoying a majority in the Legislature was compelled to give way by the Congress Parliamentary Board with Nehru's threat of resignation and allow the Governor to recommend the imposition of President's Rule despite the claim that the constitutional machinery had broken down being an 'official fiction'. ${ }^{315}$ Even Prasad questioned the validity of the application of President's Rule in his name arguing that 'the Ministry has been functioning, and can function even now, with the support and enjoying the confidence of a majority of members of the Legislative Assembly. Even in tendering his resignation the Chief Minister has not said that he has lost the confidence of the Assembly but only that he is tendering his resignation in obedience to a directive of the Congress Parliamentary Board'. ${ }^{316}$

The "emergency" die had been cast and continues to roll. ${ }^{317}$ As President surrendered to pressure, realising that he had "no option but to accept the report and be "satisfied" that the situation contemplated in Article 356 has arisen', he also meekly stated, as many of his successors would sympathise, that 'I cannot help feeling that we have acted against the spirit of the Constitution although the action may be justified as being in strict accordance with its letter'. ${ }^{318}$ A "dead letter" it was not. The Centre would actively rule over the States through political and legal mechanisms encased in the Constitution.

\footnotetext{
${ }^{314} \mathrm{He}$ also had been a supporter of Patel while he was alive, which may have influenced Nehru's distaste for the Punjabi Chief Minister. See B. D. Dua, "The Prime Minister and the Federal System" in Nehru to the Nineties - The Changing Office of Prime Minister in India, p 24

315 Austin, Working a Democratic Constitution, pp 157-158 and 606-607

${ }^{316}$ Prasad to Nehru, 18 June 1951, Dr Rajendra Prasad: Correspondence and Select Documents, Vol. XIV, p 72

${ }^{317}$ For example in May 2005 the Congress appointed Governor of Bihar dissolved the Legislature, which prevented the Opposition BJP coalition from forming a Government. The Governor then recommended President's Rule for Bihar. The Union Cabinet met close to midnight on 22 May 2005 and agreed with the Governor's recommendation and this was faxed to President A.P.J. Kalam who was in Moscow for a State visit. He faxed in consent within three hours of receiving the Cabinet's advice and President's Rule was declared immediately. The Supreme Court later criticised the Cabinet for believing the Governor's report as the "gospel truth" and argued that this was incorrect invocation of Article 356 since it based on "mere personal ipse dixit [unsupported assumption]" and the BJP accused the Prime Minister of misleading the President and called on Dr Singh to resign. The Time of India, 25 January 2006 ${ }^{318}$ Prasad to Nehru, 18 June 1951, Dr Rajendra Prasad: Correspondence and Select Documents, Vol. XIV, p 73
} 
The strategy propounded in the fourth century Arthasastra - that subordinate rulers shall be preserved and respected in their customs and territorial jurisdiction if they acknowledge, via respect and tribute, the superior authority of a ruler of rulers - government the statecraft of subcontinental empires in Mughal and British times. After independence, India's federal system became its modern embodiment within the twentieth century subcontinental empire. ${ }^{319}$

This historic legacy of governance imbued itself into its modern federal manifestation and acknowledged, as its predecessors had, the importance of localised and broad accommodation tempered by the indisputability of the Centre's powers as the sovereign authority.

A land the size, scope, diversity and complexity of India make it susceptible to multiple and cross cutting cleavages. However, the exile of the most fervent Muslim elements to the new state of Pakistan removed a significant pressure of a rival "nation" within independent India. The creation of Pakistan demoted and defused religion as the principle cleavage of Indian political life. For example though Hinduism represented almost eighty-five per cent of the population it was difficult to mobilise politically since the secular orientated Congress under Nehru had always declined such strategies and more importantly Hinduism lacked organisational confessional cohesiveness since it was already dramatically divided and criss-crossed by multifarious ideological, linguistic, ethnic, regional and class loyalties and identities. On the language issue, Hindi the major language of India only constituted around forty per cent (not to mention various dialects of Hindi) in 1951 and in this polyglot land any attempt of linguistic hegemony by one language was fiercely opposed, especially by non-Hindi speakers. In fact English was directed by the Constituent Assembly to remain the official language of government and also for communication between the States for fifteen years while the major regional languages were used within their own provinces and were recognised as "national" languages with their inclusion into the Eighth Schedule of the Constitution. ${ }^{320}$ The most crucial political implication that arises from the above facts is

\footnotetext{
${ }^{319}$ Lloyd I. Rudolph and Susanne Hoeber Rudolph, In Pursuit of Lakshmi-The Political Economy of the Indian State, Chicago: University of Chicago Press, 1987, p 66

${ }^{320}$ For more information on the major cleavages see Jyotirindra Dasgupta, Language Conflict and National Development - Group Politics and National Language Policy, Berkeley: University of
} 
that the numerous ethnolinguistic divisions instead of causing the threat of disintegration of the Indian State, 'contributed instead to political pluralism' since, unlike its neighbours, no one ethnolinguistic group in India commands a majority. ${ }^{321}$

This social truth enabled the national and unity thinking Union Cabinet and Constituent Assembly headed by Nehru to create a flexible federal structure which largely contained and accommodated the potentially divisive diversities of their new nation. Atul Kohli, writing fifty years after independence, argues that there are two 'variables' that are important to understanding self-determination movements. The first is the level of institutionalisation of the central state' and the second is the degree of accommodation from the central leaders to demands for self-determination. Kohli believes that the more the authority of the central state is institutionalised and the more accommodating the ruling strategy' the more likely it is for success after a period of negotiation. Kohli justifies this with the proposition that 'a well-institutionalised state sets firm boundaries within which political movements must operate, on the one hand, and, on the other hand, an accommodating leadership provides room - of course, within limits - for the movements to achieve real gains'. ${ }^{322}$ India, as has been argued above had the strong centre with institutionalised power from its leader derived from the Constitution and also wanted to provide for the plurality of the country. Though determined to maintain the territorial integrity of the nation the Nehru era was 'a period when India's central state was relatively well institutionalised and leadership strategy, though firm, was also flexible and accommodating to demands for self-determination'. ${ }^{323}$

The Constitution as discussed above gave strong powers to the Centre to maintain the territorial integrity of the country as well as the political might to deal with any regional or communalist threats. As well as those emergency powers, Articles 2, 3 and 4 gave the Parliament in Delhi extensive powers to organise and demarcate states as they desired, allowing the national legislature 'by law to admit a new state, increase, diminish the area of any State or alter the boundaries or name of any State' without the

California Press, 1970 and "India: Democratic Becoming and Developmental Transition" in Politics in Developing Countries - Comparing Experiences with Democracy, $2^{\text {nd }}$ edition, Larry Diamond, Juan J. Linz and Seymour Martin Lipset (eds.), Boulder: Lynne Rienner Publishers, 1995, pp 287-294 and Brass, The Politics of India since Independence, pp 162-164

${ }^{321}$ Christophe Jaffrelot, "India and Pakistan: Interpreting the Divergence of Two Political Trajectories", Cambridge Review of International Affairs, Vol. 15, No. 2, 2002, pp 257-259

${ }^{322}$ Atul Kohli, "Can Democracies Accommodate Ethnic Nationalism? Rise and Decline of SelfDetermination Movements in India", The Journal of Asian Studies, Vol. 56, No. 2, May 1997, pp 329-330 ${ }^{323}$ Kohli, "Can Democracies Accommodate Ethnic Nationalism? Rise and Decline of Self-Determination Movements in India”, pp 332-333 
need for any consultation or consent with the parties involved. ${ }^{324}$ The new Government inherited from the British a set of provinces that were multi-lingual and seldom conformed to ethnic concentrations. Congress had always been committed to reconfiguring the States on more credible lines of language and ethnicity to reform the internal map of India. However, with the trauma of Partition and the need for a centralised authority to maintain order and implement much needed India-wide economic planning, Nehru was reluctant to feed any fissiparous tendencies by redrawing the map.

Nehru, though having sympathy, was worried that this would create secessionism and erode a national consciousness producing a 'boiling cauldron of redistribution all over India'. ${ }^{325}$ Nehru and the Cabinet were forced to deal with demands, especially from linguistic groups, for separate recognition as federal units. The first major agitation came from the Telegu speaking areas of South India (the second biggest language group in India after Hindi). ${ }^{326}$ In the early fifties they clamoured for their own state to be formed from the Telegu speaking areas of the former princely state of Hyderabad and the British created Madras Presidency. In 1952 a fast unto death was begun by Telegu leader and Gandhian disciple Potti Sriramalu for the establishment of Andhra Pradesh as a Telegu State. His subsequent death from starvation aroused riots and violence in Southern India and the State of Andhra Pradesh was conceded and formed on linguistic lines. The action compelled the 'frazzled' Cabinet in New Delhi to rethink their intransigence towards the redrawing of State boundaries and similar agitations from other linguistic groups hastened the establishment of the States Reorganisation Commission in $1953 .^{327}$

The Commission reported back in 1956 and the States were realigned largely on a linguistic basis and the process continued with gradualism in the later Nehru years and beyond. Importantly the Commission did not advocate any changes to the Centre-State relations provisions but predicted that the reorganisation would serve India's "unity and

\footnotetext{
${ }^{324}$ Dasgupta, “India's Federal Design and Multicultural National Construction”, p 58 and Articles 2, 3 and 4 in Basu, Constitutional Law of India, pp 5-6

${ }^{325}$ See Chapter 12 "The Problem of Linguistic States" in Gopal, Jawaharlal Nehru - A Biography, Volume Two: 1947-1956, pp 256-271 and Jalal, Democracy and Authoritarianism in South Asia - A Comparative and Historical Perspective, p 165

${ }^{326}$ Brass, The Politics of India since Independence, p 159

327 James Manor, "Centre-State Relations" in The Success of India's Democracy, p 85 and Jalal, Democracy and Authoritarianism in South Asia - A Comparative and Historical Perspective, pp 165-166
} 
security”, which it did. ${ }^{328}$ The 1956 States Reorganisation thus tweaked and fine tuned Indian federalism to be better able to contain India's pluralism without diminishing the Centre's omnipresence. The process also showed that local leaders wanted to retain both their cultural prerogatives and active membership of the Indian Union 'in a manner that contributed to the durability of federalism, ${ }^{329}$ As Manor argues, Nehru's fears of the erosion of central authority and secessionism proved unfounded. Though a country of India's size and diversity constantly faced social pressures from various groups for recognition the fact was that like other cleavages in India 'it quickly became apparent that the States Reorganisation had undermined and not intensified linguistic group assertiveness ... Linguistic fervour waned. Given such heterogeneity within linguistic states [such as subregional groups, castes, economic groups, sects etc], it would be impossible to generate the kind of state-level solidarity that was needed to develop secessionist movements. It was this central reality that Nehru and writers who had foretold the balkanisation of India had failed to see before 1956'.330

India's form of federalism tended to localise and somewhat mitigate regional problems by segmenting them within the state arena. India's federal packaging combined with its multi-stranded pluralism is essential to maintaining solidity since they compartmentalise potential conflict to the regions with an omnipresent Centre to intervene if necessary. As Weiner states, India's 'social structure and constitutional forms thus combine to quarantine violent social conflict and political instability at the state level' ${ }^{331}$ In addition, Nehru emphasised the importance of integration and cohesion and strove to establish the conventions regarding the appointment of State Governors the State concerned was always consulted despite being a Central non-elected choice and that 'only persons from outside the State were appointed'. ${ }^{332}$ Despite Nehru being initially and naturally concerned that he might be catalysing further partitions he eventually 'recalculated that the dangers of not devolving power to linguistic groups were greater than of doing so. Fully in control at the national centre and widely considered to be India's legitimate leader, Nehru set firm limits on what powers the newly constituted states would have and what would be controlled by New Delhi (which, by the way was

\footnotetext{
${ }^{328}$ Austin, Working a Democratic Constitution, pp 155-156

${ }^{329}$ Dasgupta, "India's Federal Design and Multicultural National Construction”, pp 60-61

${ }^{330}$ James Manor, "How and Why Liberal and Representative Politics Emerged in India", Political Studies, Vol. XXXVIII, 1990, p 35

${ }^{331}$ Weiner, The Indian Paradox - Essays in Indian Politics, p 36

${ }^{332}$ Tummala, "The Indian Union and Emergency Powers", p 375. These conventions did last long after Nehru's death.
} 
substantial)'. The States Reorganisation took a 'fair amount of the separatist steam' out of movements emanating from the Tamil nationalists for instance who received a State largely based on linguistic lines in $1956 .{ }^{333}$

Nehru and the Cabinet had not compromised the territorial integrity of India or weakened the power of the Centre in the Indian federal system - but had largely accommodated the plethora of social forces of plural India and upheld their ideal of a composite nation with a co-operative federalism protected and conserved by the Centre. This federal interpretation was 'largely determined by ... Nehru. He was responsible for expanding and crystallising the role of the Centre' and also providing assurance to the regions. ${ }^{334}$ Though not without its problems, India has achieved a consociational existence through its federal structure, which in turn required 'the contribution of prudent and constructive leadership in the development of successful power-sharing system' and Nehru, as Lijphart assesses 'is an almost perfect example of such leadership'. ${ }^{335}$ Federalism, though far from perfect, was cemented in this period and was a lasting path-dependent influence upon India. Though many today argue that India's system needs reforms, 'few would see any practicable alternative' to federalism. $^{336}$ The critical importance of India's inimitable federal design was fundamental as a path dependent factor that has enabled India to function as a credible and cohesive entity to this day.

\footnotetext{
${ }^{333}$ Kohli, "Can Democracies Accommodate Ethnic Nationalism? Rise and Decline of Self-Determination Movements in India", pp 333-335

${ }_{334}$ Dua, "The Prime Minister and the Federal System", p 23

${ }^{335}$ Arend Lijphart, "The Puzzle of Indian Democracy: A Consociational Interpretation", American Political Science Review, Vol. 90. No. 2, June 1996, p 262

${ }^{336}$ Copland and Rickard, "Introduction", in Federalism - Comparative Perspectives form India and Australia, p 18
} 


\section{"British is Best" - An Elite Faith}

In contrast to the fissiparous tensions that characterised the colonial experience in India, the small island of Ceylon seemed to gently and courteously accomplish its own independence with the minimum of fuss on 4 February 1948. Ceylon's cultural conditions at first seemed at variance with its vast northern neighbour. Not only Britain, but the Ceylonese political elite also, sought continuity for the new Dominion. In fact many 'dignified' elements of British culture remained. "God Save the King" was retained as the National Anthem, the Union Jack flew next to the Ceylon flag on public buildings, Imperial Honours were still bestowed (with great interest), Ceylonese debutantes were still presented at Buckingham Palace - and there were also key personnel who stayed in their posts and thus ensured a smooth and reassuring transition. Along with senior military, judicial and civil service personnel - the Governor of the Crown Colony of Ceylon, Sir Henry Monck-Mason-Moore, was retained and translated on independence into the first Governor-General of the Dominion of Ceylon.

More importantly the first Prime Minister, D.S. Senanayake, and the Cabinet were seasoned politicians who were instrumental to the hand over of power and with their long governmental experience and participation (and education) were actively conditioned and acculturated in the constitutional conventions required in British eyes for a successful and peaceful political future. The outward confidence and signs of peace, prosperity, bespoke suited patricians at the helm, and the amicability of the transfer of power disguised the vast heterogeneity of people and tensions that would radically test the country in the years to come. The decade following independence demonstrated the constitutional and political pressures, which tested the wisdom of Ceylon being a model state. Ceylon has for almost all its history been a multi-ethnic society. According to the 1953 census there were eight million people that inhabited the island. The Sinhalese comprise about seventy per cent of the population and are mainly Buddhist, living in the south and centre of the island, while eleven per cent are Ceylon Tamils who are mainly Hindu, living in the north and east. The Ceylon Tamils are distinct from the Indian Tamils, brought in by the British to work on the tea plantations. 
Other smaller groups include the Muslims and the Burghers, descendents of Portuguese, Dutch and British marriages with the Ceylonese. ${ }^{337}$

The constitution that Ceylon received at independence was preceded by seven other constitutions drafted between 1801 and 1947, and was the 'product of colonial legal evolution. $^{338}$ The importance of this point is crucial in viewing and analysing the impact and accommodation of the British system in Ceylon as an implanted Westminster. Although British culture with its 'dignified' apparatus was foreign to the masses, it was familiar to and accepted by the political elite. The constitution of 1947 with few alterations was the product of the recommendations of the Soulbury Commission 1944-45 and hence the first constitution of independent Ceylon, which lasted till 1972, was generally known as the Soulbury Constitution. As South Asian scholars have noticed, unlike India, Ceylonese 'governments and legislators made no attempts, soon after independence, to frame a new constitution themselves. During the first quarter-century after independence, the constitution under which the country was ruled was that written substantially by a British constitutional lawyer in the years leading up to the transfer of power. ${ }^{339}$ Ceylon displayed the dignified tenets of Westminster, but would fail to grasp the mastery of the efficient parts of Westminster when it came to operation of executive power.

How Ceylon and later Sri Lanka dealt with this legacy has been subject to enduring controversy. In comparing the three constitutions that Sri Lanka has had since independence, one of Sri Lanka's most prolific historians has noted that the 'most striking feature' of the Soulbury Constitution 'was that it came closer to the Westminster model than most other Commonwealth constitutions' and unlike India or Pakistan independence was legally conferred through 'a mere Order-in-Council' rather than through an Act of Parliament. ${ }^{340}$ Though the sovereign reality of Ceylon's independence was in no way less than its larger South Asian cousins, there were distinct differences in the style and manner of independence such as the resistance to calls for a constituent assembly or any alacrity whatsoever towards republicanism or anti-British

\footnotetext{
${ }^{337}$ For further information of Ceylon's people and history from the period see W. Howard Wriggins, Ceylon: Dilemmas of a New Nation, Princeton, New Jersey: Princeton University Press, 1960, pp 11-51

${ }^{338}$ Radhika Coomaraswamy, Sri Lanka - The Crisis of the Anglo-American Constitutional Traditions in a Developing Society, New Delhi: Vikas, 1984, p 8

${ }^{339}$ Foreword by Regi Siriwadena in Radhika Coomaraswamy, Ideology and the Constitution - Essays on Constitutional Jurisprudence, New Delhi: Konark Publishers, 1997, p ix

${ }^{340}$ K.M. De Silva, "A Tale of Three Constitutions 1946-8, 1972 and 1978”, The Ceylon Journal of Historical and Social Studies, Vol. VII, No. 2, June-December 1977 (published in 1979), pp 1-3
} 
sentiment from the political elites. Ceylon aimed to be a truly British Westminster and not an adapted Westminster as was the case in most transplanted and implanted countries.

One of the reasons Ceylon developed strong attachment to British culture and favoured the Royal Commonwealth was due to the fear of its large northern neighbour dominating the subcontinent. For Ceylon and also Pakistan in this era, if India was not countered by the Commonwealth she would be unrestrained from pursuing hegemony in the region. The Ceylonese Foreign Secretary, Sir Kanthiah Vaithianathan, said that 'Ceylon's real interest in the Commonwealth was to have the United Kingdom's support as a counterweight to India' ${ }^{341}$

The Soulbury Constitution succeeded the Donoughmore Constitution, which was in operation from 1931 to September 1947. The key features of the Donoughmore Constitution was that it established (in the year that Statute of Westminster was passed in London) universal adult suffrage (Ceylon became the first Asian country to enjoy this boast ${ }^{342}$ ); abolished communal representation, which was replaced by territorial representation; transferred large control over internal policy to elected representatives of Ceylon; and established a system of executive committees. Despite provisions for certain areas of legislative and executive power reserved for the Imperial power, the measures were substantial and as the Colonial Secretary eulogised at its passing in 1947 it was an 'experiment in adult suffrage and in responsible democracy, and it contributed much to the political maturity and drive for effective democracy of the people of Ceylon'. ${ }^{343}$ The Donoughmore Constitution determinedly rejected communal representation and did not suggest any alternative (such as federalism) to contain communalism. This noble attempt to achieve national unity by means of constitutional reform that entailed the abolition of communal representation stirred growing distrust and resentment amongst the communities. Interestingly, the Simon Commission and the Round Table Conference were formulating schemes for electoral and constitutional safeguards for minorities in India at the same period as the Donoughmore Commissioners were rejecting such a system of communal representation in Ceylon and

\footnotetext{
${ }^{341}$ Moore, Making the New Commonwealth, p 181

${ }^{342}$ Ceylon had universal suffrage twenty years before its adoption in India and just two years after Britain itself.

${ }^{343}$ S. Namasivayam, Parliamentary Government in Ceylon, 1948-1958, Colombo: K.V.G. De Silva \& Sons, 1959, pp 12-13
} 
pressing for national integration and territorial representation. ${ }^{344}$ Significantly the minorities protested in the Legislative Council against the abolition of the electorates. ${ }^{345}$

This distaste of the Donoughmore commissioners towards communal representation was completely in line with Westminster axioms. However, the system of executive committees was not. Instead of the 'conventional' quasi-cabinet structure, which aspiring local politicians sought and expected on the path to self-government, these bureaucratic-legislative committees of the unicameral State Council were modelled on the London County Council and were explicitly meant to give experience in administrative and political affairs, through the seven committees of this difficult and novel system. ${ }^{346}$ The Donoughmore Constitution was radical since it did not seek to replicate Britain's model especially since there was a 'non-existence of party system', on which Britain's was based. The Commissioners could 'detect few signs in the political life of the Island to make us confident that parties' would function as in Britain and instead be based on 'racial or caste divisions'. ${ }^{447}$ This contrast made the Commissioners agree that it "must be our aim not slavishly to follow the forms and practice of the British model which was not designed to meet conditions similar to those obtaining in Ceylon'. ${ }^{348}$ However, the Donoughmore Constitution rather than materialise to foster a national non-communal spirit in fact served to intensify elite domination as the only actors capable of grasping what was a still a foreign concept to most of the population. The new constitution though hardly Westminster gave local leaders 'positions of authority unimaginable in most of Britain's colonial possessions' since they were a trusted westernised elite long competent as servants of the Crown. ${ }^{349}$

The Soulbury Constitution that followed was the result of a commission headed by Lord Soulbury in 1944-45 to consider a new constitution for the colony. Britain after the fall of Singapore and the goodwill, wartime participation and effective delegations of Ceylonese politicians conceded that self-government would arrive after the war. The

\footnotetext{
${ }^{344}$ S. Arasaratnam, "Nationalism in Sri Lanka and the Tamils", in Sri Lanka-Collective Identities Revisited - Vol. II, Michael Roberts (ed.), Colombo: Marga Institute, 1998, p 297

345 C.A. Woodward, The Growth of a Party System in Ceylon, Rhode Island: Brown University Press, 1969 , p 35 - The issue of communalism will be discussed more fully below.

${ }^{346}$ K.M. De Silva, A History of Sri Lanka, (special Sri Lankan edition), Colombo: Vijitha Yapa, 2005, pp 521-522

${ }^{347}$ [Donoughmore Report] Colonial Office, Ceylon: Report of the Special Commission on the Government of Ceylon, Cmd. 3131, London: His Majesty's Stationary Office, 1928, p 41

${ }^{348}$ Donoughmore Report, Cmd. 3131, pp 45-46

${ }^{349}$ S. R. Ashton, "Ceylon" in The Oxford History of the British Empire: Volume IV - The Twentieth Century, Judith M. Brown and Wm. Roger Louis (eds.), Oxford: Oxford University Press, 2001, pp 454455
} 
main constitutional tenets of the document which became with few alterations the constitution of Ceylon was universal suffrage; a bicameral legislature - consisting of a House of Representatives of 101 members of whom 95 were directly elected from territorial electorates and a Senate made up of 30 members - 15 elected by proportional representation by the Lower House and the rest appointed by the Governor-General on the advice of the Prime Minister; and the establishment of a Westminster Cabinet i.e. a parliamentary executive spawned from the legislature though selected by the Prime Minister and appointed by the Governor-General as the King's Representative.

Ceylon was a parliamentary unitary democracy and constitutional monarchy - a model of a British Westminster not of adapted Westminster, which had conspicuously more safeguards and was generally federal in character. The constitution, as shall be shown below at the political executive level, had little to condition itself to the Ceylonese context. The premise was that 'the British and the Sri Lankan elites believed that the Constitution and political life would be animated and restrained by the customs and conventions which surround parliamentary democracy in Great Britain'. ${ }^{350}$ In the sixteen years of the Donoughmore Constitution, which criticised the absence of political parties and yet did little to foster their growth by concentrating power in committees, rather than a legislature - it had at least recognised the difficulty in the mere replication of the British Westminster model.

However, the Soulbury Commissioners almost with resignation believed like the local elite that "British is best" and that it was the most suitable model for Ceylon. The Soulbury Report could state that their British model inspired constitution was recommended because 'the majority - the politically conscious majority of the people of Ceylon - favoured a constitution on British lines. Such a constitution is their own desire and is not being imposed upon them'. The report's conclusion continued with what in hindsight seems like constitutional and cultural carelessness in the approach to applying the British Westminster model to Ceylon, hoping that the Ceylon elite's cognisance and affectation of British culture would mitigate the paucity of political appreciation amongst the Ceylonese of the efficient operation of Westminster institutions:

\footnotetext{
${ }^{350}$ Coomaraswamy, Sri Lanka - The Crisis of the Anglo-American Constitutional Traditions Traditions in a Developing Society, $\mathrm{p} 12$
} 
The Constitution we recommend for Ceylon reproduces in large measure the form of the British Constitution, its usages and conventions, and may on that account invite the criticism so often and so legitimately levelled against attempts to frame a government for an Eastern people on the pattern of Western democracy. We are well aware that self-government of the British Parliamentary type, carried on by means of a technique which it has taken centuries to develop may not be suitable or practicable for another country, and that where the history, traditions and culture of that country are foreign to those of Great Britain, the prospect of transplanting British institutions with success may appear remote. But it does not follow that the invention of modifications or variations of the British form of government to meet different conditions elsewhere will be any more successful ... At all events, in recommending for Ceylon a Constitution on the British pattern, we are recommending a method of government we know something about, a method which is the result of very long experience, which has been tested by trial and error and which works, and, on the whole, works well. ${ }^{351}$

The Soulbury Report thus concluded that since it worked well and for centuries in Britain it was more than good enough for Ceylon. It was Britain or bust. But beyond the minority of the charmed circle of the island's political and social elite this was not accurate for Ceylon's path to independence. The constitution and the independence process had not captured the national imagination and thus its new negotiated constitution lacked populist and nationalist rapture to endear its contests to the wider population. S.W.R.D. Bandaranaike, a former secretary of the Oxford Union, acerbically captured some of that sentiment after he resigned from the first Cabinet:

Then came freedom. But how did freedom come? It came not after a fight upon definite principled policies and programmes, but it really came in the normal course of events, that is, attempts to persuade Commissions sent from England to grant this little bit or that little bit extra, and, finally, in the wake of freedom that was granted to countries like India, Pakistan and Burma, our Soulbury Constitution was altered to extend to us the same type of Dominion Status. There was no fight for that freedom which involved a fight for principles,

\footnotetext{
${ }^{351}$ [Soulbury Report] Colonial Office, Ceylon: Report of the Commission on the Constitution, Cmd. 6677, London: His Majesty's Stationary Office, 1945, pp 108-109
} 
policies and programmes which could not be carried out unless that freedom was obtained. No. It just came overnight. We just woke up one day and we were told, "You are a dominion now". 352

\section{Cabinet - A Dignified Façade of Factional Operation}

On the day Ceylon achieved its independence from the British Empire the first Prime Minister of Independent Ceylon, D.S. Senanayake, broadcast proudly to the nation that 'for the first time for a thousand years we have today become a free and united nation'. Unlike the romantic nationalism that his counterpart, Nehru, had expressed in his address on India's tumultuous and fierce road to independence just months earlier, Senanayake was purposefully moderate and reassuring. With an eye to India no doubt the avuncular Ceylonese Prime Minister continued that with Ceylon's path to independence 'there are no refugees crossing Elephant pass, the Ceylon Light Infantry is organising a party to welcome its Colonel-in-Chief, and the only explosions we shall hear will be those of the fireworks.' Senanayake accurately expressed Ceylon's status, from his point of view, when he stated happily that independence 'had been achieved without bloodshed and with no more controversy than was to be expected in so complicated and delicate a process as the framing of a new Constitution. That we owe in part to the British people. They have taken longer than we wished, and I for one have had to say hard things about them in the past, but they have lived up to the liberal traditions of a great people'. ${ }^{353}$ Senanayake was proud of the constitutionalist method of his country's independence and concurrently the British Westminster system that this implied, rather than adapting for Ceylon peculiar circumstances. Ceylon with pride and diligence maintained this constitutional concert.

As the Prime Minister explained to his people, in language that the former colonial power could only approve of, 'the King is no longer merely King of the United Kingdom, acting on the advice of his British Ministers. He has also become King of Ceylon, acting on the advice of his Ceylon Ministers. You will find that for the first time he and not the Governor or Governor-General is part of our Parliament and that executive powers are vested in him in order that they may be exercised by the responsible Government in office for the time being. ${ }^{354}$ The close relationship between the Governor-General and Prime Minister and the executive powers vested in their

\footnotetext{
${ }^{352}$ E.F.C. Ludowyk, The Modern History of Ceylon, London: Weidenfeld and Nicolson, 1966, p 204

${ }^{353}$ D. S. Senanayake's Broadcast, February 4 1948, Jennings Papers, Ceylon B3, ICS125, ICS

${ }^{354}$ Senanayake's Broadcast, February 4 1948, Jennings Papers, Ceylon B3, ICS125, ICS
} 
offices would be fundamental to all aspects of Ceylon's post-independence politics as will be seen in chapter six. This dualist relationship of duopolistic connotations would go far beyond the parameters of Westminster 'efficient' operating culture and overshadow the Cabinet - which, similarly, was not operating according to collegial Westminster values and attitudes despite its 'dignified' Westminster façade.

[D.S. Senanayake was] to repeat the figure of speech so frequently used then, the architect of Ceylon's freedom. What he built, what he was responsible for constructing on behalf of the elite whom he represented so remarkably well, was a new façade with a burnished brass plate on the door: Free Ceylon. It was the outward and visible sign of all the elite had been pressing for since 1910. The structure raised by the British remained intact; inside there was some rearrangement. A number of Ceylonese previously relegated to rooms without a view moved higher up; they could stride the corridors of power with more confidence and even peer out of the commanding heights of the structure. The new façade was impressive; it delighted those who filed in and out of the building as the new VIPs ... The Ministers in the Cabinet of 1947 could feel ... that they had all they wanted and more. ${ }^{355}$

Rather than feel some liberating cathartic desire to reform or recreate their implanted constitution, the new elite sought the Westminster embrace. The early Cabinets of Ceylon showed a definite inclination towards doing things the "British way" in terms of ceremony and royalty the new Dominion showed the Bagehotion 'dignified' British culture par excellence. A leading politician was able to impress Britain after independence with the assurance they should 'think of Ceylon as a little bit of England' and with foolhardy confidence gushed that 'Ceylon will rival Australia as the first Dominion to rally to the side of the Mother Country'. ${ }^{356}$ Though not quite the feeling of the entire elite and Cabinet, it was not hyperbole either. The Cabinets at least until 1956 were dominated by the elite whose affluence, education and social backgrounds engendered them to find congruence with the British cultural way. The Soulbury Report recognised this:

\footnotetext{
${ }^{355}$ Ludowyk, The Modern History of Ceylon, p 204

356 The politician was none other than Sir Oliver Goonetilleke. Cited from James Manor, The Expedient Utopian - Bandaranaike and Ceylon, Cambridge: Cambridge University Press, 1989, p 199
} 
It must be borne in mind that a number of the political leaders of Ceylon have been educated in England and have absorbed British political ideas. When they demand responsible government, they mean government on the British parliamentary model and are apt to resent any deviation from it as "derogatory to their status as fellow citizens of the British Commonwealth of Nations and as conceding something less than they consider their due". To put it more colloquially, what is good enough for the British people is good enough for them. ${ }^{357}$

However, what the Commissioners and the elite blithely ignored was that what worked in Britain would not necessarily work in a country that lacked, for all its affection for British culture, a thorough working knowledge and participation of the 'efficient' mechanics of Westminster operational culture. Ceylon enjoyed the trappings of monarchy, which had always been part of its culture. D. S. Senanayake liked to claim that Elizabeth II was the latest in the long and ancient line of Sri Lankan monarchs. Sir Ivor Jennings commented on the inference -

A good deal of ingenuity is required to prove the apostolic succession from Prince Vijaya to Queen Elizabeth, but nationalist history is not less influential through being romantic as the story of King Arthur and the Knights of the Round Table. ${ }^{358}$

The Ceylonese had a genuine affection for the Crown, but the Queen was always Queen of England to the masses. The trouble was that the idea of the Queen of Ceylon was almost entirely an elite conception. Though legally correct, it was difficult to explain that an English Queen was actively part of the Ceylon constitution and not merely taken from a book of fairytales demonstrating the dangerous fantasy of the Ceylonese elite in thinking they were some latter day Rajas of the Round Table.

The first four Prime Ministers were all schooled at one of the two leading Colombo colleges, wealthy landowners, high caste Buddhist Sinhalese ${ }^{359}$ and all studied, with the exception of the first, at Oxford or Cambridge. They all had gained their political

\footnotetext{
${ }^{357}$ Soulbury Report, Cmd. 6677, p 110

${ }^{358}$ Sir Ivor Jennings, "Crown and Commonwealth in Asia", International Affairs, Vol. 32, No. 2, April 1956, p 137

${ }^{359}$ S. W. R. D. Bandaranaike though brought up as an Anglican had converted to Buddhism well before he became Prime Minister in 1956.
} 
training through many years experience under colonial tutelage in the auspices of the pre-independence legislature and all except the relatively youthful Dudley Senanayake had also had extensive tenure as ministers during the Donoughmore era. They all had a long apprenticeship in the legislature before gaining the seals of office as Prime Minister - S.W.R.D. Bandaranaike twenty-five years, D.S. Senanayake twenty-three years, Sir John Kotelawala twenty-two years and Dudley Senanayake the shortest, but still substantial period of sixteen years. ${ }^{360}$

The Ceylonese Cabinets 1948-1958 also contained considerable common characteristics. More so than Britain and the transplanted New Westminsters cabinet in Ceylon in these years was demographically 'somewhat federal' in deference to the plurality of the island. Though consideration was given to the heterogeneity of nationality, caste, religion and region the Cabinet was remarkably homogenous at least until 1956 in terms of wealth, high social status, elite Christian denominational or government secondary schooling and often further education in Britain. Though till 1956 there were generally nine low-country Sinhalese, two Kandyan Sinhalese, two Ceylon Tamils and one Muslim in Cabinet reflecting an element of composite arrangement the common elite social and economic background of these men belied their symbolic diverse representation. An example of this exclusivity was of the men who served in the first Cabinet two were from Oxford, four from Cambridge, six from the University of London, four from the Ceylon Law College while all but one attended one or other of the country's leading secondary schools. ${ }^{361}$ When D.S. Senanayake provided a memorandum on the high and 'dignified' cabinet doctrine of collective responsibility he furnished his paper, using the constitutionally ubiquitous Jennings's assistance, with laudable examples from the administrations of such ancient Westminster luminaries as Viscounts Melbourne and Palmerston and the Marquess of Salisbury, which would have found resonance with most of his Cabinet colleagues especially the Oxbridge ones. ${ }^{362}$ That said, no matter how often British Westminster traditions were voiced it was more to display erudition and comfort than to put in to practice or develop to meet the unique needs of the Ceylon polity.

\footnotetext{
${ }^{360}$ For further material the most comprehensive analysis of the backgrounds of Ceylon's early Prime Ministers and Cabinets can be found in A. Jeyaratnam Wilson, "Ceylon Cabinet Ministers 1947-1959 Their Political, Economic and Social Background”, The Ceylon Economist, Vol. 5, No. 1, March 1960, pp $1-54$

${ }^{361}$ Wilson, "Ceylon Cabinet Ministers 1947-1959 - Their Political, Economic and Social Background”, pp $1-54$

${ }^{362}$ Note by the Prime Minister on Collective Responsibility, undated, Jennings Papers, Ceylon B3, ICS125, ICS
} 
The Ceylonese elite that composed the early Cabinets were very much like their transplanted cousins with the depth of knowledge, education of the British Westminster system and even the outward signs of dress and social niceties. ${ }^{363}$ They happily acceded to the implant and admired the felicity and authenticity with which the British had planted their own institutions in to Ceylon. Sir Oliver Goonetilleke smugly proclaimed in the New York Times in 1952 that 'Ceylon is the best job the Englishman has done anywhere in the world, almost better than in his own country'. ${ }^{364}$ For elite figures like Goonetilleke, there was truth to this sentiment. Ceylon's peaceful path to independence and readiness to accept Britain's sponsorship was in contrast to India and Ceylon's leading figures were happily cognisant of British Westminster, which they did view as merely continuing the colonial axioms. However, there were serious differences compared to transplanted countries with their well-established mechanics of a party system and the associated elite and mass awareness of how the formal Westminster institutions were 'efficiently' operated through informal conventions and an operating culture of attitudes and values that had evolved spontaneously or accidentally, but were as important to a Westminster system as the 'dignified', symbolic culture associated with its ceremonial rather than operational aspects.

The Westminster fixation of centralisation coupled with the nascent, urban and elite dominated parties' failure to extend organisationally around the country disabled the ability to spread institutions and endow local knowledge of government. One scholar has labelled this a serious 'failure of political integration' and argues that the 'elite/mass discontinuity, rather than the Sinhalese/Tamil discontinuity, is the principle cleavage in the polity in Sri Lanka' of that early period. ${ }^{365}$ Due to the lack of cohesive national mass movement and fragmentary nature of existing associations most parties were formed in anticipation of the 1947 elections. The Donoughmore Constitution's State Council, as discussed above, did not engender cabinet or party loyalties or practices. As

\footnotetext{
${ }^{363}$ They even shared their names. In the thirty years that followed independence of the seven individuals that held the office of Prime Minister only Mrs Bandaranaike and W. Dahanayake had Ceylonese first names while Don Stephen, Dudley, John, Solomon West Ridgeway Dias, and Junius Richard had such European names despite all seven being Sinhalese Buddhists.

${ }^{364}$ Cited in Woodward, The Growth of a Party System in Ceylon, $\mathrm{p} 3$

${ }^{365}$ James Manor, "The Failure of Political Integration in Sri Lanka (Ceylon)", Journal of Commonwealth and Comparative Politics, Vol. XVII, No. 1, March 1979, p 22
} 
Jennings explains the constitution, which Ceylon had until 1947 'was designed to suit a legislature without parties and therefore actively discouraged then'. 366

Unlike Britain or India, the parties that gained power did not have experience, were not well established and lacked party discipline more functioning around leaders. As such most parties at the time were 'stamped by the idiosyncrasies of their dominating personalities' since almost 'no party institution is well enough established to resist the characteristics and peculiarities of its leaders'. ${ }^{367}$ The United National Party (U.N.P.) for instance was formed just a year before the out of the rubble of ineffective organisations such as exclusivist elite Ceylon National Congress and essentially became the Senanayake family party and was known as the "Uncle Nephew Party". The conservative and intensely moderate Ceylon National Congress was founded in 1919, but waited until 1942 to advocate independence. ${ }^{368}$ The Sri Lanka Freedom Party was very much the personal creation of S.W.R.D. Bandaranaike and it was only constituted in 1951 on his disgruntled resignation from the Senanayake Cabinet. ${ }^{369}$

Most other parties were 'based on either communal or social divisions, though some were little more than cliques led by dominant personalities' and most, including the U.N.P., offered little in the way of a detailed manifesto instead in concentrated on personal attributes. ${ }^{370}$ Despite being led by Senanayake, the U.N.P. was unable to gain a majority in 1947 to govern alone, requiring support from minor parties including the Tamil Congress and Independents. Cabinet therefore was more a grouping of factions surrounding the leader than the vanguard of the majority party as in most New Westminsters. With minimal party institutionalisation Cabinet lacked the collegial, and yet disciplined attitudes and values of Westminster Cabinet culture.

Cabinets and parties were during the ten years after independence a collection of discernible followings and loyalties. Unlike India's post-independence Cabinet there was no party oligarchy of well-established leaders. The heterogeneity of Ceylon and cosmetic depth of the party system in the early years meant that the power and necessity

\footnotetext{
${ }^{366}$ Sir Ivor Jennings's analysis of the 1947 General Election cited from Woodward, The Growth of a Party System in Ceylon, p 43

${ }^{367}$ Wriggins, Ceylon: Dilemmas of a New Nation, p 105

${ }^{368}$ Ashton, "Ceylon", p 453

${ }^{369}$ Bandaranaike had been a senior Minister under D.S. Senanayake and resigned over policy and personal differences and believed he would not succeed the "Old Man", which he thought was his for the taking. See Manor, "Heir Presumptive", The Expedient Utopian, pp 168-204

${ }^{370}$ Woodward, The Growth of a Party System in Ceylon, pp 52-67
} 
associated with cabinet membership was often used, though mindful of its powerful representative function in Ceylon, for personal interests of the leader. As W. Howard Wriggins has stated -

In a country where personalities play such an important role, cabinet loyalty had been enhanced where the widespread popularity of the party's leader becomes, to some extent, a substitute for a party organisation and program. No doubt in the three elections in independent Ceylon, certain M.P.s had been brought to parliament on the coattails of the three elected prime ministers. This was true in the popular upsurge of emotion toward Dudley Senanayake in 1952 and S.W.R.D. Bandaranaike in 1956. There are relatively prominent men who are likely to be cabinet material in any event, but it is a significant fact that there are those who have entered parliament and even become ministers primarily because of their close association with the prime minister rather than from any other identifiable source of political strength. ${ }^{371}$

With such use of patronage and personal followings the politics of Ceylon was more akin to eighteenth-century Westminster than the twentieth-century Westminster. Two distinguished British visitors observed as much. On the day of independence Patrick Gordon Walker wrote from Colombo to his Labour Cabinet colleagues that socially and politically 'Ceylon is a mixture of feudalism and eighteenth century landed aristocracy' with leaders who with their wealth, local power and influence were 'comparable to a Whig landlord in George III's time. They have much the same attitude towards politics. Public life is riddled with affable and open corruption, moral and otherwise'. ${ }^{372}$ While ten years later the Conservative Prime Minister, Harold Macmillan recorded in his diary from Ceylon with perspicuity that "no regular Party system on modern British lines has developed' and instead 'in a curious way, the political life is more like that of Whig politics in the eighteenth century than one would suppose. The leading figures have a "following" (like the Bedfords or the Rockinghams)'. ${ }^{373}$ Such analysis was in tune with the reality of the close confines of a parochial political class solidified by kinship and

\footnotetext{
${ }^{371}$ Wriggins, Ceylon: Dilemmas of a New Nation, p 100

372 'Report on Ceylon': Cabinet Memorandum by Mr Gordon Walker, 17 March 1948 in British Documents on the End of Empire, Series B - Sri Lanka, Part II, Towards Independence 1945-48, K. M. De Silva (ed.), London: Her Majesty's Stationary Office, 1997 p 369

${ }^{373}$ Harold Macmillan, Riding the Storm 1956-1959, London: Macmillan, 1971, p 395
} 
patronage rather than party and professionalism. ${ }^{374}$ As one dissident Ceylonese communist stated in 1968, himself a cousin of Mr. Bandaranaike, the political power system in Ceylon was 'a game of musical chairs by which a Bandaranaike (S.L.F.P.) or a Senanayake (U.N.P.) can alternatively come to power'. ${ }^{375}$

Such politics is natural when the cabinet and party system is embryonic and as such Prime Ministers and leaders rely on followings, which in such a society as Ceylon is often family, rather than the Westminster leanings on cabinet and a rigid disciplined party. The Westminster places the burden of power upon the Prime Minister with the expectation that he or she will be supported through a party system by a Cabinet of colleagues but this was not available in the early years in Ceylon as the party system was based essentially, as one substantial study puts it, on the premise that parties are based on 'a group of ambitious men who have chosen politics as a vocation and who seek personal success ${ }^{376}$, rather than the traditional disciplined loyalties of the twentieth-century Westminster model of organised parties. Ceylon's Westminster system of Cabinet government functioned without the fundamental factor of an entrenched and comprehensive party structure instead relying on personalist factions. This in turn led to Cabinet as institution operating in a culture of attitudes and values that differed markedly from the Westminster model and was more like that of British Cabinets in the eighteenth century that predated the institutionalised party system that became a feature of most twentieth century Westminsters.

Patronage and personalised power was the key in this era to maintain loyalty rather than party authority. For instance even during the relatively tranquil and unchallenged era of the first Senanayake ministry, 23 of 101 members of the elected lower house held government office, which as Wriggins explains 'is no doubt excessive' for Ceylon's size and yet 'the extreme diversity of the island's people, the multiplicity of interests to be represented, and the tendency for followers to rally around an individual rather than a party suggests that it was an expedient move at the outset', which created a precedent followed by all his successors. ${ }^{377}$ In the U.N.P. and S.L.F.P. leaders emerge like in the old British Conservative Party, without any consultation with lesser and lower elements of the party. Even the prominent smaller parties were very much the creations and

\footnotetext{
${ }^{374}$ For an interesting account of Sri Lankan family politics see Inder Malhotra, Dynasties of India and Beyond - Pakistan Sri Lanka Bangladesh, New Delhi: Harper Collins, 2003, pp 231-245

375 James Jupp, Sri Lanka - Third World Democracy, London: Frank Cass, 1978, p 47

${ }^{376}$ Woodward, The Growth of a Party System in Ceylon, p 19

${ }^{377}$ Wriggins, Ceylon: Dilemmas of a New Nation, p 115
} 
creatures of their leaders such as the Communists under Dr S.A. Wickramasinghe, Dr N.M. Perera's L.S.S.P., S.J.V. Chelvanayakam's Federal Party and G.G. Ponnambalam's Tamil Congress. ${ }^{378}$

This political tendency towards personalised, leader-follower factionalism often meant levels of disunity within the Cabinet and sometimes Parliament also especially after the death of D.S. Senanayake, whose stature as the independence leader clouded this feature. Dudley Senanayake's first ministry was occupied with rupture over the succession with Kotelawala and his supporters; Kotelawala's abrasive personality angered many within the Cabinet; while Bandaranaike's coalition Cabinet were highly restive and divided over the many controversial policies and domestic crises that faced his brief government. ${ }^{379}$ However, though Prime Ministers may have had to make concessions to groups at times, due to the absence of true party accountability theirs was a delegative democratic power direct from the people, which enabled them to go over the heads of their parliamentary colleagues and party members to the electorate, where they derived their real political power (they also became a prisoner of such expectations of the electorate especially over issues like communalism, which will be discussed below). The system, which Westminster model assists, is leader-centric. The patronage ridden and factional nature of Cabinet and Party Government during this era meant that in Ceylon -

The role of primus inter pares is difficult to fill. Power and deference tend to be drawn away from the equals into the hands of the outstanding leader, a fact which makes it all the more difficult to succeed to his place. Disputes between colleagues could often be resolved only by the party leader himself. He became the dramatic focus of organisational loyalty and public interest. In all parties, whoever was conceded to be the leader was given a wide scope for policy initiative. The rank and file did not presume to have views that counted; by their competition, members of the entourage, including cabinet colleagues, ensured that the prime minister had the last word. ${ }^{380}$

This lack of Westminster culture of collegial attitudes and values based on shared institutional attachment to a party rather than personal loyalties to a leader meant a

\footnotetext{
378 Jupp, Sri Lanka - Third World Democracy, p 100

${ }^{379}$ See Wilson, “Ceylon Cabinet Ministers 1947-1959”, pp 14-44

${ }^{380}$ Wriggins, Ceylon: Dilemmas of a New Nation, p 149
} 
higher level of political instability and difficulty to make strong political and policy decisions as will be shown in the following chapters. It also meant that there was minimal horizontal accountability within the cabinet to prime ministerial authority. The Ceylonese political leaders saw cabinet as place of patronage and were not acculturated to Westminster Cabinet collegiality that was even evident in Nehru's India. In the formative years of Ceylonese independence it was the relationship between the Governor-General and the Prime Minister, which formed the real and crucial focus for executive power and analysis. 


\section{Executive Affairs - The Ceylonese Partnership of Convenience}

The colonial legacy, the absence of institutionalised modern democratic like established parties and activist civil society of mass understanding meant that power was more often personalist and delegated. Executive power in Ceylon in its first decade centred on, and was delegated to, the Governor-General and Prime Minister rather than the more traditional Westminster focus on Prime Minister and Cabinet. The first decade following independence produced a unique relationship between the Head of State and Head of Government that dominated the deliberations of state like few other Westminsters. Horizontal accountability existed on these political actors from each other, but seldom in the traditional theoretical Westminster sense. A partnership arose and oscillated in power terms between the Governor-General and Prime Minister depending on the holders and political circumstances, but their political partnership always impacted on Ceylon's Westminster executive more than any other.

\section{Head of State}

His Majesty's Government of Ceylon took almost ostentatious regard to preserve and present to the world that it would be a Westminster system - and a British one at that. In fact along with all the ceremony, dress and panoply associated with royalty, the Governor-General was referred to, and not in jest, as Rajjuruwo ${ }^{381}$ (Sinhala for King) while resident at Queen's House, the palatial seat of the colonial rulers since Dutch times. This was in contrast to Nehru's India, which wanted to rapidly topple its Dominion status and embrace republicanism. Indeed D.S. Senanayake would proudly claim to his fellow Prime Ministers that Ceylon was the oldest monarchy in the Commonwealth as George VI was the legitimate and constitutional successor of the Kandyan kings. ${ }^{382}$ As the prime author and authority on the Ceylon constitution, Jennings himself stated of the new constitutional structures, "what is provided, in short, is constitutional monarchy of the British type'. ${ }^{383}$ However, the constitution, unlike Britain's, specified to a great detail the expectations and powers of the Governor-

${ }^{381}$ Tarzie Vittachi, Emergency '58 - The Story of the Ceylon Race Riots, London: Andre Deutsch, 1958, p 70

${ }^{382}$ L. M. Jacob, Sri Lanka - From Dominion to Republic, Delhi: National Publishing House, 1973, p 33

${ }^{383}$ Sir Ivor Jennings, The Constitution of Ceylon, $3^{\text {rd }}$ edition, Oxford: Oxford University Press, 1953, p 50 
General as the King's Representative and constitutional Head of State. How much could the "British type" headed by the Governor-General function successfully in Ceylon and act, as in Britain, as the constitutional arbiter and guardian? The expectation was that the Governor-General would follow the precedents in Britain of the Monarch. Lest there be any doubt of that intention the constitution explicitly stated in Section 4(2) of the Ceylon (Independence) Order-In-Council, 1947 that

All powers, authorities and functions vested in ... the Governor-General shall...be exercised as far as may be in accordance with the constitutional conventions, applicable to the exercise of similar powers, authorities and functions in the United Kingdom by His Majesty. ${ }^{384}$

During the period analysed there were three Governors-General - Sir Henry MonckMason-Moore (1948-49), Viscount Soulbury (1949-54) and Sir Oliver Goonetilleke (1954-62). Moore had been the last Governor and had a long career in the Colonial Service; Soulbury headed the Commission that bears his name and had been a British Conservative Minister before and during the War; while Goonetilleke was deeply involved in the transfer to power, and was the first High Commissioner to the United Kingdom, President of the Senate and Minister of Home Affairs amongst other high positions - they were thus all men with considerable experience who knew the country and its Constitution well. The constitutional provision cited above sought to mitigate the nascent nature of the constitutional apparatus and the lack of familiarity and history of the conventions, which Britain, and not Ceylon, had evolved. However, as one legal scholar noted, though the Governor-General of Ceylon was legally required to act in accordance with the constitutional conventions in the United Kingdom, he is still 'the ultimate authority in a particular situation of what the conventions is, and the manner of its application' and has the power to adapt to local situations since he only needed to follow British conventions 'as far as may be' and his actions could not be held to account by any court of law. ${ }^{385}$

In many respects the powers, prerogatives and expectations of the Ceylon GovernorGeneral would be greater than the nominal ruler they represented at Buckingham Palace. Even Dr. N.M. Perera, the erudite radical Marxist member for Ruwanwella,

\footnotetext{
${ }^{384}$ Ceylon Constitution, Section 4(2) in Jennings, The Constitution of Ceylon, p 169

${ }^{385}$ L.J.M. Cooray, "Operation of Conventions in the Constitutional History of Ceylon, 1948 to 1965", Modern Ceylon Studies, Vol. 1, No. 1, 1973, pp 7-9 and Jennings, The Constitution of Ceylon, p 169
} 
who opposed the "sham independence", recognised in the House of Representatives that the Governor-General 'must ... be a sort of beacon light that will shed lustre and light in our social and political life'. ${ }^{386}$ The Soulbury Constitution gave on paper substantial powers to the head of state vis-à-vis the executive and legislature. Along with customary powers of a Westminster head of state, the majority of which are exercised on the advice of the Prime Minister, such as being Commander-in-Chief, summoning, proroguing and dissolving of Parliament and the appointment of the Prime Minister and Cabinet as well as senior judicial, military and civil service officers, the Ceylon Governor-General had certain unique powers.

The Governor-General was given the power through the Constitution to appoint half the Senate and most importantly six members to the House of Representatives. Such provisions of selection were seen from certain angles as an opportunity to include in Parliament some of the country's many ethnic, linguistic, regional, social and religious groups, since the traditional Westminster-derived electoral system could not otherwise deliver to the legislature representation of the these many interests on the island. Sir Henry Moore, while still Governor, writing to the Colonial Secretary on the proposed Soulbury Constitution, believed that his future powers as Governor-General would mitigate minority qualms since there would be 'much less of communal feeling if we could secure a reasonable representation of community interests in the Upper House and in the Cabinet' and as such suggested that he receive 'Royal Instructions on the subject in making his nominations to the Upper House, even if he is to exercise no discretion in the appointment of Ministers'. 387 This clearly showed the veteran proconsul's mind in regard to the Governor-General's future powers.

The Senate and the Governor-General's discretion of appointments to that House and the nominated members to the lower house were hoped by officials like Moore to appease the eloquent, but aggressive demands from the Tamil leader, G.G. Ponnambalam, for protected representation of minorities arguing in reaction to the Westminsteresque Soulbury Constitution for "fifty-fifty", the equal division of representation in the legislature between the Sinhalese and other communities. ${ }^{388} \mathrm{~A}$ previous Governor, Sir Andrew Caldecott, had argued that they should have Royal

\footnotetext{
${ }^{386}$ Namasivayam, Parliamentary Government in Ceylon 1948-1958, p 24

${ }^{387}$ Letter from Sir Henry Moore to Mr Stanley, 25 July 1945 in British Documents on the End of Empire, Series B - Sri Lanka, Part II, Towards Independence 1945-48, p 23

${ }^{388}$ See Chapter Seven
} 
Instructions, as in British India after 1935, which would allow the Head of State in appointing the Cabinet 'to use his best endeavours, in consultation with the person likely to command a majority in the Legislature, to select those, including so far as practicable members of important minority communities, who would inspire confidence'. ${ }^{389}$ However, no such "Instructions" ever materialised and the Constitution did not provide such interpretations of emphasis in regard to the theoretical and practical employment of the Governor-General's powers of appointment.

\section{Prime Minister}

Unlike most transplanted examples, the Constitution of implanted Ceylon explicitly mentioned the office of Prime Minister. Part V of the Constitution expressly mentions members of the Cabinet and Parliamentary Secretaries, the Head of the Cabinet to be the Prime Minister, the observance of the principle of collective responsibility to Parliament, and for such members and Secretaries to hold office during His Majesty's Pleasure. The Order even stipulates that there must be a Minister of Finance and a Minister of Justice. Other than the stipulation that at least two ministers, one of whom shall be the Minister of Justice, must come from the Senate the Prime Minister's power of appointment and patronage is unencumbered constitutionally in the assignment of portfolios and personalities from parliament. ${ }^{390}$ Uncommonly, and most likely to do with Senanayake's pledge to maintain Ceylon's strategic and defence capabilities for British and Commonwealth interests, the Constitution also instructs that the Prime Minister is in charge of Ministry of Defence and the Ministry of External Affairs. ${ }^{391}$

If one can call that stipulation an adaptation to local conditions there were no other formal constitutional allowances for Ceylonese circumstances such as communal seats at the Cabinet table. Though the first Prime Minister and most of his successors were very much in favour of the British system, the Ceylonese Prime Minister was certainly 'not under the same express legal obligations to follow British conventions, as the

\footnotetext{
${ }^{389}$ Sir Frederick Rees, "The Soulbury Commission 1944-45”, The Ceylon Historical Journal, D.S. Senanayake Memorial Number, Vol. V, Nos. 1,2,3 \& 4, July \& October 1955 and January \& April 1956, p 28

${ }^{390}$ Ceylon Constitution, Part V, Sections 45-51 in Jennings, The Constitution of Ceylon, pp 216-224

${ }^{391}$ Ceylon Constitution, Section 46 (4) in Jennings, The Constitution of Ceylon, p 216. The Soulbury Report pushed for this unique inclusion since they argued a Prime Minister 'as Head of Government, would be the most suitable repository for the information on Imperial Defence policy...the Minister of Defence, on instructions when necessary from the Imperial Authorities received through the GovernorGeneral would the instrument through which Imperial policies would be carried out'. See Soulbury Report, Cmd. 6677, p 95
} 
Governor-General is ${ }^{392}$ and thus not subject to such high constitutional horizontal accountability. The Constitution established formally responsible cabinet government very much in the Westminster mould. However, this did change the crucial detail that the Prime Minister and Cabinet were institutions of government 'which was alien to Ceylon in October 1947', when D.S. Senanayake formed his first Cabinet. ${ }^{393}$ As has been discussed in the previous chapter, along with minimal analogous cultural education for the electorate to embrace and understand such theories and bodies, the whole experience of British rule had not even adequately prepared the colony to encompass Westminster cabinet government. The previous quixotic Donoughmore Constitution, as discussed above, did not provide for such political institutions, but had individualist ministries with key powers still held by colonial officials and the Governor himself, rather than a proto-executive or Cabinet-in-waiting. Even Jennings weakly admitted that 'it is not possible to change a tradition by Order in Council, but the new Constitution did its best'. 394

In many ways Ceylon's independence was a personal transaction between the British and D.S. Senanayake. After the marginalisation of Sir Baron Jayatillike in the late 1930s, Senanayake became the premier politician on the island and with O.E. (later Sir Oliver) Goonetilleke as his able assistant, cannily negotiated the terms of independence. The British decided that with Senanayake at the helm they had a safe assurance of Ceylon remaining in the Commonwealth and access to the naval base at Trincomalee and Royal Air Force station at Katunayake, which were viewed by senior British military and political sources as highly integral to Britain's defence planning in the uncertain post-war era. ${ }^{395}$ The British saw that 'without Senanayake's cooperation, power in Ceylon would undoubtedly fall into the hands of extremists and all that His Majesty's Government and Ceylon stood to gain by the new Constitution would be

\footnotetext{
${ }^{392}$ Cooray, "Operation of Conventions in the Constitutional History of Ceylon, 1948 to 1965", p 13

${ }^{393}$ Namasivayam, Parliamentary Government in Ceylon 1948-1958, p 34

${ }^{394}$ Jennings, The Constitution of Ceylon, p 101

395 An example of this view came from the redoubtable Admiral Sir Geoffrey Layton who advocated that their importance was so great that he hoped that Britain's 'object must be to see that the Imperial Government have, through the Governor-General, an effective voice in policy in such matters' and optimistically thought the Governor-General should in the 'interests of Imperial defense' have a 'second set of advisors [from H.M.G. in London] in addition to responsible Ministers' since it 'would not be a practicable proposition in such a case to rely wholly on the impartiality of a "non-political" Ceylonese [official].' - 'Defence policy for Ceylon': Memorandum by Admiral Layton for Sir H. Markham (Permanent Secretary, Admiralty), in British Documents on the End of Empire, Series B - Sri Lanka, Part II, Towards Independence 1945-48, pp 132-133. For further information on the Defense Agreements see Jacob, Sri Lanka - From Dominion to Republic, pp 23-27 and 195-196
} 
lost. ${ }^{396}$ Senanayake's sponsor Soulbury wrote to the Colonial Secretary for further concessions for Senanayake and argued that there was a danger of power leaving the pro-Britain, moderate, but ageing Senanayake and finding a home with the nationalist, leftist exponent of non-alignment that Bandaranaike represented and starkly warned that 'it would not be wise to exclude the possibility of finding him [Senanayake] in the same camp as $\mathrm{Mr}$ Bandaranaike being driven there in an effort to preserve his own leadership. ${ }^{397}$ Senanayake implied this fear when on the same day he wrote that he could lose his majority to the leftist nationalists since 'I am already being accused of having offered too much and asked too little'. ${ }^{398}$ In the end as in India, Pakistan and many of the future African states like Ghana, the British effectively entrusted the sovereignty to one man - D.S. Senanayake. Gordon Walker, representing the British Government at the Independence Day celebrations, recorded pleasingly that 'Senanayake is in the genuine tradition of Dominion Prime Ministers: deeply committed to the British connexion'. 399

\section{The First Era of Delegative Democracy}

With the undoubted kudos of achieving independence, Senanayake was a powerful Prime Minister. The above fact was one of the main sources of Senanayake's political powers - rather than being the leader of a political party as in most comparable situations in the Commonwealth, since his party, the U.N.P., unlike Congress for example in India, was not a well established or well-organised hegemonic political force with grass roots support. But Senanayake, as he was to the British, was a reassuring politician to the masses and Parliament. Irrespective of his constitutional status of Prime Minister he was "Father of the Nation" and drew confidence from that image that his successors could not, since they, more than he, required the powers of office derived from the Constitution. But more importantly Senanayake was the first man invested with the powers over the new Dominion and thus he had the political ascendancy and delegated democracy from which he derived institutional security, which his successors lacked to such a degree. 400

\footnotetext{
${ }^{396}$ Letter from Mr Senanayake to Mr Hall, 12 September 1945 in British Documents on the End of Empire, Series B - Sri Lanka, Part II, Towards Independence 1945-48, p 91

${ }^{397}$ Letter from Lord Soulbury to Mr Hall, 5 October 1945 in British Documents on the End of Empire, Series B - Sri Lanka, Part II, Towards Independence 1945-48, pp 106-109

${ }^{398}$ Letter from Mr Senanayake to Lord Soulbury, 5 October 1945 in British Documents on the End of Empire, Series B - Sri Lanka, Part II, Towards Independence 1945-48, p 113

399 'Report on Ceylon': Cabinet Memorandum by Mr Gordon Walker, 17 March 1948 in British Documents on the End of Empire, Series B - Sri Lanka, Part II, Towards Independence 1945-48, p 365

${ }^{400}$ De Silva, A History of Sri Lanka, pp 600-604
} 
Senanayake was able therefore to be largely effective as he was the dominant personality and 'he did not so much dictate as he arbitrated between the wings', but with his 'popular support and an appeal approaching charismatic ... in the end he could always impose his will'. ${ }^{401}$ In the period of analysis Ceylon had four Prime Ministers - D.S. Senanayake (1947-52), Dudley Senanayake (1952-53), Sir John Kotelawala (1953-56) and S.W.R.D. Bandaranaike (1956-59). The personalities of these holders of the premiership and their relationship with party and cabinet are highly essential in understanding the powers of their office in the institutionally nascent years after independence - and also demonstrate certain cultural characteristics that discriminate Ceylon from the other Commonwealth countries at the executive level.

As discussed above, the vast majority of the Governor-General's powers are subject to the advice of the Prime Minister, which is stipulated in the Constitution under Section 4 (2). However, there are some areas that allow certain manoeuvrability - the apex of these personal prerogatives is the appointment of the Prime Minister. In the traditional Westminster system it is the two-party system that transacts the business of Parliament. The Queen's role is to offer the premiership to the person who holds the confidence of the lower house. In transplanted countries this is invariably the leader of the party who numerically controls a majority of seats over the opposition - with two parties this is a relatively automatic decision of simple arithmetic leaving little discretion or difficulty for the Head of State to decide on who to bestow a commission to form a government. In implanted countries the party system at the time of independence is relatively embryonic and far from two established parties - there is generally a plethora of factions masquerading as parties with little cohesion and discipline that is expected from their cousins in the settler Dominions. Even India had at least the security of the Congress's dominance until the present day, which made a simple choice for the President. The nature of Ceylon's party system as analysed above was characterised by the novelty, incidence and irregular nature of parties during the period of analysis were such that the Governor-General's disbursement of the seals of office is not so explicable. It did not help that none of the major parties, including the U.N.P., had any reliable or formal machinery of electing leaders, which added to the political ambiguity and uncertainty that surrounded the succession to D.S. Senanayake. ${ }^{402}$

\footnotetext{
${ }^{401}$ Woodward, The Growth of a Party System in Ceylon, p 75

${ }^{402}$ Cooray, "Operation of Conventions in the Constitutional History of Ceylon, 1948 to 1965", pp 10-11
} 
Indeed Ceylon's very first commission to become Prime Minister was offered by Sir Henry Moore to D.S. Senanayake despite the blatant psephological fact that his party, the United National Party, after the General Election of August-September 1947 did not hold an absolute majority in the House of Representatives. However, Senanayake's appointment to form a ministry was largely without controversy as Moore had commissioned the person best able to command the confidence of the House. Such constitutional conduct from the Governor-General was in spite of the dissimilarity to the usual British experience, but was in line with Westminster conventions, which the Ceylon Governor-General was constitutionally bound to honour. Remembering that in the respect of constitutional conventions Ceylon was quite a legal abnormality compared to the other Realms. Jennings contends that though it is 'entirely satisfactory ... to have established the formal law as in Australia and to leave the conventions to be implied', in Ceylon it 'had to be established by law' and thus the country was peerless, since its Constitution 'specifically provides for the application of the constitutional conventions of the United Kingdom' ${ }^{403}$ For all the implicit and explicit emphasis on Westminster conventions the quandary of their interpretation, and more importantly application, was prominent in this period from the Governors-General and Prime Ministers themselves. Those two offices had three crucial partnerships that demonstrated the flexibility and difficulty of Westminster conventions as well as the complexity and fluctuation of horizontal accountability in Ceylon.

\section{The First Partnership: The Soulbury Compact with the Senanayakes 1949-53}

Lord Soulbury, with his old friend "D.S." safely ensconced at Temple Trees, the Prime Minister's Official Residence, with meagre prospects of office under an unwelcome Labour Government back home, must have relished the vice-regal opportunity to return to the Island and succeed Sir Henry Moore, who stayed on for just a year, as GovernorGeneral in 1949. Soulbury back in Ceylon could indulge, as he enthused, in his aesthetic savouring of Ceylon's renowned 'traditions of art and architecture and literature and thought that in bygone centuries made her people famous'. ${ }^{404}$ However, if the masses and political elite thought that this bemonocled sartorial English aristocrat, with impeccable credentials for the post, would quietly spend his years on the island rummaging through the ancient ruins of Polonnaruwa and act from Queen's House with

\footnotetext{
403 Jennings, The Constitution of Ceylon, p 171

${ }^{404}$ Independence Day Souvenir, Independent Ceylon - The First Year, issued by the Department of Information, The Government of Ceylon, 1949
} 
the impartiality and correctness as is the convention of that high office and as he himself stated keep out of politics and refrain from any activities which may give rise to the suspicion of political influence...', they were to be greatly mistaken. ${ }^{405}$

Senanayake and Soulbury were very close since the days when the former Conservative Minister visited as head of the Commission to deliberate on Ceylon's constitutional future in 1944-45. They bargained well with each other during the Commission's time and understood the importance of their political relationship as trusted allies and enjoyed their weekly informal meetings as Prime Minister and Governor-General. ${ }^{406}$ They had an intimate relationship and though Soulbury was very much the junior in this partnership he was not an ignorant or insignificant partner. As he himself stated of their political partnership:

It was my duty in accordance with constitutional usage to accept and act upon his advice, but he was always ready to listen to advice from me, though of course he did not always take it nor did I expect him to ... sometimes however I used to tell him that the only advice he really ought to accept was the advice that his doctor and I gave him... 407

Unquestionably the most important event of Soulbury's tenure was the death of Senanayake and his role in the appointment of his successor to the premiership. Soulbury had a good relationship with the anglophile elite that dominated Ceylon at the time, especially due to his previous role in heading the Commission that had his name and his advocacy in the House of Lords and Whitehall for Ceylon's independence. In Soulbury they saw a true custodian of the constitution and a 'dignified' upholder of the "British way", which they so readily empathised and mimicked. Many also saw that at this stage only an Englishman, above the petty differences of the locals, could maintain standards and order. And yet as James Manor argues, 'the first major violation of the conventions of Westminster to occur in the island was the work of an Englishman, 408 ,

\footnotetext{
${ }^{405}$ Lord Soulbury, "I Remember Ceylon”, in Times of Ceylon Annual 1963, cited in A. Jeyaratnam Wilson, "The Role of the Governor-General in Ceylon", Modern Asian Studies, Vol. 2, 1968, p 195 ${ }^{406}$ Lord Soulbury, "Senanayake the Man", Appendix 1 in H. A. J. Hulugalle, Don Stephen Senanayake First Prime Minister of Sri Lanka, $2^{\text {nd }}$ edition, Colombo: Arjuna Hulugalle Dictionaries, 2000, pp 286292

407 Soulbury, "Senanayake the Man”, p 291

408 James Manor, "Setting a Precedent by Breaking a Precedent: Lord Soulbury in Ceylon, 1952", in D.A. Low (ed.), Constitutional Heads and Political Crises - Commonwealth Episodes, 1945-85, London: Macmillan, 1988, p 28
} 
none other than Herwald Ramsbotham, G.C.M.G., G.C.V.O., O.B.E., M.C., P.C., first Baron, later Viscount, Soulbury in the County of Buckinghamshire.

On 21 March 1952 Prime Minister D.S. Senanayake suffered a stroke and fell from his horse during an early morning ride on Galle Face Green, and after being taken to hospital, died the next afternoon. ${ }^{409}$ Soulbury had only recently arrived in Britain, but hastened to return to Colombo, where the Chief Justice Sir Alan Rose, was Acting Governor-General, and under strict instructions from Soulbury that in the event of Senanayake's death (unbeknown to most, the sixty-seven year old diabetic was dying before the incident) Rose was not to appoint a successor until the Governor-General's return five days later. ${ }^{410}$ On his return the choices that lay before Soulbury for the office of Prime Minister were Dudley Senanayake, the late Prime Minister's forty-one year old son and Minister of Agriculture and Lands and Sir John Kotelawala, Leader of the House of Representatives (a position locally regarded as de facto deputy Prime Minister - though constitutionally, like Britain, there was no official post of deputy Prime Minister), Senior Vice-President ${ }^{411}$ of the ruling U.N.P. and nephew of D.S. Senanayake. According to certain sources Kotelawala, the most experienced member of the Cabinet after the late Prime Minister and who deputised for him in his absence, commanded the support of the majority of MPs of the U.N.P. ${ }^{412}$ While Dudley Senanayake seemed to have a 'melancholy aversion to politics' and was relatively inexperienced, critically he had the active support of his kinsman's powerful Lake House press. ${ }^{413}$ Soulbury wasted no time on his arrival to carry out his duty - as he saw it. Manor describes the controversial and rapid events:

Lord Soulbury's plane landed at $12.35 \mathrm{pm}$ on 26 March and he drove straight to Queen's House ... He held no consultation of any substance with any Member of Parliament, and at $1.55 \mathrm{pm}$, less than an hour after the Governor-General had reached the residence, Dudley Senanayake arrived. After a 45-minute interview, the latter proceeded to the Cabinet room nearby where he met for ten minutes

\footnotetext{
${ }^{409}$ For a more detailed account of the episode and Senanayake's health see K.M. De Silva and W. Howard Wriggins, J.R. Jayewardene of Sri Lanka - A Political Biography, Vol. One: 1906-1956, London: Anthony Blond/Quartet, 1988, pp 250-258

${ }^{410}$ De Silva and Wriggins, J.R. Jayewardene of Sri Lanka - A Political Biography, Vol. One: 1906-1956, pp 254-260

${ }_{411}$ Effectively deputy leader of the Party

${ }^{412}$ Manor, "Setting a Precedent by Breaking a Precedent: Lord Soulbury in Ceylon, 1952", p 30

${ }^{413}$ Manor, "Setting a Precedent by Breaking a Precedent: Lord Soulbury in Ceylon, 1952", p 30 and De Silva and Wriggins, J.R. Jayewardene of Sri Lanka - A Political Biography, Vol. One: 1906-1956, pp 254-260
} 
with ministerial colleagues. He then returned to Queen's House to accept formally the summons to be Prime Minister ... By calling a man other than the one who could command the majority of the ruling party's MPs, he [Soulbury] had breached one of the most fundamental conventions of Westminster. ${ }^{414}$

Even a British Governor-General did not apply Westminster conventions. Why had Soulbury done so? Various sources believe that he was 'completing his great transaction with D.S. Senanayake', whom he greatly admired and was beholden to for his present post that was offered over a 'long talk on the lake at Bolgoda. ${ }^{415}$ The Prime Minister, advised Soulbury, whose appointment was directly recommended by Senanayake, that should anything happen to him he should send for his son to lead the government, rather than Kotelawala. ${ }^{416}$ Soulbury had always publicised how his old friend "D.S." was almost 'irreplaceable ${ }^{417}$ and perhaps the son was as good a substitute as possible. To many it seemed that Soulbury 'had paid off his debt' to D.S. Senanayake. ${ }^{418}$ Whatever the conjecture, the events were highly extraordinary and the massive controversy that was generated was warranted. The action, with its lack of formal consultation and disregard for precedence and dereliction of the constitution itself was utterly against the Westminster system. As Kotelawala threateningly reminded his constitutional head, the Governor-General, his constitutional duty was to appoint the leader who could command the widest support in House. Before the appointment of the younger Senanayake but with rumours of the prospect gaining credence, Kotelawala stated unequivocally to Soulbury:

If you should now contemplate to act on any other basis, it is my painful duty to have to point out that such an act would constitute a serious breach of convention, besides setting up an utterly unacceptable constitutional precedent, that the Governor-General can make or break an established political Party by exercising his discretion in any method other than the conventional practice referred to ... [After his listing his senior positions as Leader of the House in

\footnotetext{
${ }^{414}$ Manor, "Setting a Precedent by Breaking a Precedent: Lord Soulbury in Ceylon, 1952”, p 30

415 Soulbury, "Senanayake the Man", p 290

${ }^{416}$ Manor, "Setting a Precedent by Breaking a Precedent: Lord Soulbury in Ceylon, 1952", p 32; De Silva and Wriggins, J.R. Jayewardene of Sri Lanka - A Political Biography, Vol. One: 1906-1956, p 253 and J.L. Fernando, Three Prime Ministers of Ceylon - An Inside Story, Colombo: M.D. Gunasena \& Co., 1963, pp 39-40

${ }^{417}$ Soulbury's radio broadcast on Senanayake's death quoted in Hulugalle, Don Stephen Senanayake First Prime Minister of Sri Lanka, pp 272-273

${ }^{418}$ Bradman Weerakoon, Rendering Unto Caesar, Colombo: Vijitha Yapa, 2004, p 8
} 
which capacity he had presided over the Cabinet in the Prime Minister's absence, and as Deputy Leader] ... I claim that there should be no delay whatever in my being summoned to form a Government. ${ }^{419}$

Soulbury, by appointing Dudley Senanayake, who at 41 was the youngest Prime Minister in the Commonwealth at the time, left Kotelawala with few options. He could have forced a caucus vote of confidence on the new Prime Minister, but such an action would cause undeniable rupture to the U.N.P., which on its own lacked an absolute majority as the party would be facing a General Election very shortly. Open revolt was unquestionably difficult in the visible and genuine midst of peasant and parliamentary panegyrics in honour of the "Father of Independence", whose son now carried the mantle. Soulbury had also delivered the initiative to Dudley Senanayake. There was one other option, Kotelawala, a seasoned member of the national legislature, who had held ministerial rank since 1936, may have contemplated appealing to Section 4 of the Constitution - which as stated above clearly commanded the Head of State to exercise power "in accordance with the constitutional conventions, applicable to the exercise of similar powers, authorities and functions in the United Kingdom by His Majesty." The unprecedented contention surrounding the appointment of Dudley Senanayake was clearly not in congruence with the conventions of the Crown and confirmed the lack of Westminster culture. ${ }^{420}$

However, despite the potential case Kotelawala could have raised, there was no recourse to bring into question Soulbury's actions since the same constitution 'provided that no act or omission on the part of the Governor-General shall be called in question on any court of law or otherwise... ${ }^{421}$ Therefore the very hopes of the Constitution on such questions could not be utilised, despite the intention that what were practices in other Westminster countries, were in Ceylon 'laws and not conventions' since as two eminent constitutional scholars wrote (before the incident) the country 'had never known conventions so there was much to be said for giving the additional moral authority of legal enactment'. ${ }^{422}$ Kotelawala had no ability to legally challenge the GovernorGeneral's astonishing use of legalised convention. The injured politician eventually agreed to return to and serve in his relative's Cabinet, but not before threatening to

\footnotetext{
${ }^{419}$ Sir John Kotelawala, An Asian Prime Minister's Story, London: George G. Harrap \& Co, 1956, p 80

${ }^{420}$ Namasivayam, Parliamentary Government in Ceylon 1948-1958, pp 35-36

${ }^{421}$ Jennings, The Constitution of Ceylon, p 169

422 The two scholars were Sir Ivor Jennings and H.W. Tambiah cited in Manor, "Setting a Precedent by Breaking a Precedent: Lord Soulbury in Ceylon, 1952”, p 33
} 
withhold the U.N.P.'s funds, which he controlled as Treasurer, leave the country and amazingly demand to become Governor-General himself. ${ }^{423}$

Soulbury himself seems to have tried retrospectively to find constitutional support for his remarkable actions. Just two days after appointing Dudley Senanayake as Prime Minister he requested and received the same day advice from another of D.S. Senanayake's great friends, the famous jurist and scholar Sir Ivor Jennings, then ViceChancellor of the University of Ceylon. Jennings, the shadow author of the constitution, had as well as by telephone conversations to Queen's House defended Soulbury's actions by privately writing to Governor-General's office that 'there is no obligation on the Governor-General to consult the Leader of the House or anyone else' and went on to point out that there was no compulsion to act on any advice except the Prime Minister's and further justified the delay in Soulbury's duty to appoint a Prime Minister or even an acting Prime Minister. Jennings continued (alluding to Kotelawala) that Soulbury did not have to consult ministers or party leaders and that 'the Leader of the House has no claim whatever to the office of Prime Minister' and then made the courageous, but highly contentious, offer, 'if the Prime Minister thinks it would help' Jennings was 'very willing to write an article for the Ceylon Daily News' to advocate the Soulbury-Senanayake position. ${ }^{424}$ Jennings arguably was colluding with or at least absolving Soulbury from his legally and politically unaccountable position. Such actions of all the main players evidenced degrees of constitutional inappropriateness and inability to commend the system to the country by blurring the constitutional responsibilities and roles of the executive actors. The entire incident demonstrated the formidable difficulty in applying the legal and theoretical intricacies of Westminster to a foreign land and culture without judicial review of constitutionally defined duties of the executive. ${ }^{425}$ Dudley Senanayake's first Government only lasted March 1952 - October 1953, when he was succeeded by Sir John Kotelawala.

\footnotetext{
${ }^{423}$ Fernando, Three Prime Ministers, pp 46-47

${ }^{424}$ Jennings to Mr Hingley (Secretary to the Governor-General), 28 March 1952, Jennings Papers, Ceylon B3, ICS125, ICS

${ }^{425}$ Whatever the constitutional irregularities of the appointment the fact that Senanayake requested and was granted a dissolution of Parliament and was returned as Prime Minister and Leader of the U.N.P. as a result of the General Election did much to mitigate the controversy surrounding Soulbury's decision.
} 
The Brief Second Partnership - The End of Soulbury and the Ceylonese friends Sir John and Sir Oliver 1954-56

Kotelawala was reputedly the author of a highly controversial document called the Prime Minister's Stakes 1952, which baldly attacked Lord Soulbury's actions as Governor-General over the appointment of Dudley Senanayake as Prime Minister. Soulbury tried, again contrary to convention, to convince the Prime Minister to sack Kotelawala sacked from the short-lived Cabinet. ${ }^{426}$ When the younger Senanayake resigned a short time later over food riots Soulbury even questioned Jennings whether there was any constitutional way of denying the premiership once more from Kotelawala by arguing that the stressed Senanayake was potentially 'unable to perform any of the functions of his office' including the crucial advice of his successor. ${ }^{427}$ Soulbury was naturally concerned with his own job security with the spectre of a new Prime Minister who reputedly believed that his meek kinsman Senanayake was 'be[ing] misled by that b... Soulbury' and was now was now the sole contender. ${ }^{428}$

Soulbury was compelled to invite Kotelawala as Prime Minister in October 1953 and now the new Prime Minister could satisfy his enduring animus against Lord Soulbury. Lacking the democratic sanction of being elected the indigenous Head of State has ultimately little practical recourse to defend and decide his powers over the wishes of a determined Prime Minister who therefore can dissipate horizontal accountability on his office from the Governor-General. Despite being a royalist, Kotelawala demonstrated this relationship when after just a month as Prime Minister he commanded the end of "God Save the Queen" being played and the Union Jack being flown on official occasions. Lord Soulbury, his old nemesis, wrote that 'he was very much peeved' at this, to which the Prime Minister responded that there were

... three points that the people of Ceylon are unable to understand. First, why in this free land should there be a foreign Governor-General? Second and third: why should there be an English flag and an English national anthem in free Ceylon? The second and third have been suitably dealt with, which may kindly be taken note of. ${ }^{429}$

\footnotetext{
${ }^{426}$ Wilson, "The Role of the Governor-General in Ceylon", p 199 and Fernando, Three Prime Ministers of Ceylon, pp 52-55

${ }^{427}$ Soulbury to Jennings, 5 October 1953, Jennings Papers, Ceylon B3, ICS125, ICS

${ }^{428}$ Fernando, Three Prime Ministers of Ceylon, p 61

${ }^{429}$ Cited from Manor, "Setting a Precedent by Breaking a Precedent: Lord Soulbury in Ceylon, 1952", p 34
} 
Soulbury, unsurprisingly, did take "note" and left the island not long after as Kotelawala had bluntly reminded the Head of State of the Prime Minister's sole prerogative to advise the Queen on the appointment and dismissal of Her Representative.

Sir John Kotelawala, now Prime Minister, wasted no time in informing the Queen on her first visit to Ceylon in 1954 of his wish to have his old friend Sir Oliver Goonetilleke as Her Representative, despite some reservations from public figures including a member of the Cabinet. ${ }^{430}$ The two were close socially and had served together under D.S. Senanayake for many years. The former pugilist told Goonetilleke that 'you are going to Queen's House even if I have to carry you there' ${ }^{431}$ Goonetilleke was another Governor-General who had high credentials to commend his appointment as the Queen's representative. He had served his country and the Empire with distinction. This Sinhalese Christian, rare for his middle class origins, rose at a time of upper caste dominance to the top of the Colonial Service on the island and helped negotiate Independence. His influence was enough for Jennings to laud how much 'Ceylon owes to Mr. [D.S.] Senanayake and to Sir Oliver Goonetilleke. But for them Ceylon would still be a colony. ${ }^{432}$ After the grant of Independence, Goonetilleke, always fearful of the electorate, was sent to the Senate as its President and served as Minister of Home Affairs in the first Cabinet and later returned to the Cabinet table as Finance Minister after an influential interregnum as Ceylon's first High Commissioner to Britain. A Knight four times over, who maintained the colonial livery, ceremonial sword and cocked hat of his English predecessors as well as the magnificence of Queen's House, the first Ceylonese Governor-General was confidentially predicted to be 'plus royaliste que la Reine'. ${ }^{433}$

Kotelawala, perhaps conscious of his sticky relationship with Soulbury wanted a Governor-General that was completely on his side supporting him personally and politically. Goonetilleke realised what was expected as one of the wiliest survivors in

\footnotetext{
${ }^{430}$ At the time of his appointment members of the Opposition was concerned over Sir Oliver's alleged involvement in a financial inquiry on the Governor of the Central Bank and R.G. Senanayake, Minister of Commerce and Trade resigned over Sir John's pro-West foreign policy and indicated his disapproval of Sir Oliver's appointment as one which would not 'inspire confidence in the Government'. See Wilson, "The Role of the Governor-General in Ceylon", p 198; Manor, The Expedient Utopian, p 245 and Kotelawala, An Asian Prime Minister's Story, pp 129-130

${ }^{431}$ Sir Charles Jeffries, 'O.E.G.' A Biography of Sir Oliver Ernest Goonetilleke, London: Pall Mall Press, 1969, p 117

432 Jennings, The Constitution of Ceylon, $\mathrm{p} \mathrm{x}$

433 'The Royal Visit to Ceylon, 1954', Jennings Papers, Ceylon B3, ICS125, ICS
} 
Sri Lankan history. Not only was he seen to be the government's 'principal propagandist' he was a chameleon as can be indicated by the view, despite his anglophile ways, that he was someone who 'if the Government found it politically expedient to create a republic Sir Oliver would find it expedient to become President' ${ }^{434}$ Notwithstanding his long service to the state he was not a popular figure with the masses and his appointment was not greeted with the popular acclaim that one could expect for the first Ceylonese Governor-General. In the beginning Kotelawala was commanded by his nominal superior to attend any public ceremony with the Governor-General 'as some kind of insulation against catcalls from the crowds'. Kotelawala openly and readily relied on the advice of someone whose long public (and party) service equipped him to discuss public and political matters of great sensitivity while the Governor-General 'on his part could deny nothing to Prime Minister Kotelawala because Sir Oliver's elevation to the post of Governor-General was due entirely to Sir John'. 435

Kotelawala, with his effective dismissal of Soulbury and conspicuous selection of Goonetilleke was complying with modern New Westminster practice of pursuing the objective of having a not unsympathetic and beholden figure as Head of State. The Governor-General, however, could not prevent a crushing electoral defeat in 1956 though there were many rumours that 'he would find some ingenious way of keeping Sir John in office'. ${ }^{436}$ Despite the constitutionally correct transfer of power, Ceylon had further and even more exceptional contributions to add to the annals of Westminster Governors-General.

\section{The Third Partnership - The Ceylonese Practitioners 1956-1959}

Goonetilleke's biographer, a senior Colonial Office official, Sir Charles Jeffries, recorded the Governor-General's candid view of the assertiveness of his role.

Sir Oliver frankly admits that he did not feel it his duty to sit in an ivory tower and let the Prime Minister of the day take all the risks of governing a country that had just emerged from colonial status to independence and was the scene of many unresolved political and economic conflicts. ${ }^{437}$

\footnotetext{
434 'The Royal Visit to Ceylon, 1954', Jennings Papers, Ceylon B3, ICS125, ICS

${ }^{435}$ Fernando, Three Prime Ministers of Ceylon, pp 79-83

${ }^{436}$ Jeffries, 'O.E.G.' A Biography of Sir Oliver Ernest Goonetilleke, p 121

${ }^{437}$ Jeffries, 'O.E.G.' A Biography of Sir Oliver Ernest Goonetilleke, p 118
} 
Under the Public Security Ordinance, No. 25 of 1947, and the Army, Navy and Air Force Acts, the Ceylon Governor-General 'is empowered, if he considers it necessary in the interests of public security and preservation of public order for the maintenance of supplies and services essential to the life of the community, to bring into operation, by Proclamation' to deal with emergencies, such immense potential power is exercised as usual are 'on the recommendation of the Prime Minister' and require communication and continuance with and from Parliament. ${ }^{438}$ Most Westminster countries have such provisions - but seldom are such articles activated. If ever such dramatic circumstances arise it is usually the Prime Minister who assumes the necessary powers - such as Churchill during World War II. The Governor-General, however, like the King, is Commander-in-Chief - but as in Britain this had been inferred in Ceylon as a nominal role and symbolic title. At the very end of our analysis of Ceylon - a decade after independence - a state of emergency was proclaimed in 1958 due to serious communal rioting between Sinhalese and Tamils which engulfed the island. Rather than a Churchillian Prime Minister coming to fore to deal with the crisis it was the GovernorGeneral, Sir Oliver Goonetilleke, who effectively lead and dealt with the crisis. As Wilson dispassionately and accurately describes the dramatic period, the GovernorGeneral -

Sir Oliver Goonetilleke functioned as Commander-in-Chief, giving directions to the armed forces and civilian officials, shifting troops to troubled areas, using ships and aircraft to transport refugees, and acting as the national censor with regard to the publication of news in the daily press. Evidence indicates that in the first few weeks of the emergency, the cabinet system broke down, ministries were unable to function, conferences even of ministers and the Prime Minister were summoned by the Governor-General at Queen's House ... Sir Oliver Goonetilleke had not only become supreme commander of the country's armed forces but its sole administrative head. ${ }^{439}$

In 1956 the U.N.P. had been heavily defeated and many expected that the radical and populist coalition under S.W.R.D. Bandaranaike would establish a new and more

\footnotetext{
${ }^{438}$ Namasivayam, Parliamentary Government in Ceylon 1948-1958, pp 27-28

${ }^{439}$ Wilson, "The Role of the Governor-General in Ceylon", p 203 and also see his "The GovernorGeneral and the State of Emergency, May 1958 - March 1959", The Ceylon Journal of Historical and Social Studies, Vol. 2, No. 2, July 1959, pp 160-81
} 
sympathetic resident at Queen's House to replace the former U.N.P. minister. However, the nationalist republican Bandaranaike kept the sly and experienced Goonetilleke on, and the Head of Government and Head of State carried on the tradition set by the first constitutional duo of lunching every Wednesday and would forge a new partnership. The constitutional chameleon Goonetilleke quickly adapted to the new regime and as the new Prime Minister generously explained to the House of Representatives in August 1956:

... I think it is a mistaken idea to imagine that the Governor-General's post is purely a decorative post. It all depends, of course, upon the individual who happens to be holding that post. I think it is only fair on my part to say that the present Governor-General works pretty hard, and that he has placed his knowledge, experience and powers which he constitutionally uses at the full disposal - as indeed constitutionally should - of the present Government. His Excellency has been most helpful on almost every occasion in assisting the Government, in so far as his functions are concerned, in carrying on the government of the country. I think I would be less than fair if I did not express my appreciation and that of the Government of the very correct constitutional manner in which the Governor-General conducts his functions and for the great assistance the Government has received from him on many occasions in dealing with many problems... ${ }^{440}$

Though he was not to know it at the time, the events of 1958 were to prove Bandaranaike correct when he mentioned that the office of Governor-General was not a 'purely decorative post', as is often considered in New Westminsters especially the transplanted countries. The Bandaranaike Government had brought in controversial legislation, which confronted the country economically and socially. The energetic and experienced Goonetilleke was useful in such a climate because the new government 'was short of gifted ministers and needed Sir Oliver's talents and personal intervention with civil servants, high military and police officers and press barons to acceptance for the new government. Sir Oliver obligingly played this role'. ${ }^{441}$ The most controversial and powerful piece of legislation was the Sinhala Only Act, which made Sinhala the official language of the country - and legalised its ascendance in

\footnotetext{
${ }^{440}$ Cited from Wilson, "The Role of the Governor-General in Ceylon", p 200

${ }^{441}$ Manor, The Expedient Utopian, pp 296-297
} 
government and education over English and Tamil. This had caused disturbances from the Tamil areas and Tamil people, which prompted Bandaranaike to make a pact with leaders of the Tamil Federal Party allowing reasonable use of the Tamil language and other regional concessions, which in turn angered Sinhala nationalists and led to the bloody and chaotic riots that hit the country just ten years after gaining a peaceful independence. $^{442}$ The events unleashed on the country a whirlwind of violence and disruption, but would also lead to an unprecedented activist role.

\section{The Fourth Partnership 1958-59 - An Emergency Makes the Governor-General Senior} Partner

Goonetilleke himself described the events as 'a cataract of looting, hysterical public killings and rapings which ruined the fair name of Ceylon, known till then as the model country in Asia where the Queen's highway was safe for anybody and where law and order prevailed'. ${ }^{443}$ There was very real tension and the Bandaranaike Government were very concerned about maintaining order and even more worried about containing and appeasing their constituents who were predominantly the Sinhala Buddhist masses. The Governor-General was very much involved with such policy and extraordinarily there is at least one recorded instance of him attending a cabinet meeting which he believed was his 'constitutional duty to advise' - and telling the Cabinet Secretary not to record his presence or his one hour monologue to his ministers on how to 'frustrate the Federal Party's [civil disobedience] campaign'. ${ }^{44}$

As a contemporary Sri Lankan academic has stated, 'the 1958 riots were the first major outbreak against the Tamils and in many ways a point of no return'. ${ }^{445}$ The country's politicians and the country's constitution were not prepared for such chaos. Bandaranaike seemed politically paralysed and weary of further raising the ire of his followers, many of whom were caught in blood-lusting madness. Bandaranaike's "wait and see" policy and continued inactivity in the face of the mobs prompted the Head of State to summon the Prime Minister and Cabinet and convinced them to advise him formally to proclaim a State of Emergency. The Governor-General already had the documents waiting to be signed on the spot, which would create him formally and practically as the senior partner. As a seasoned and consummate Whitehall and

\footnotetext{
${ }^{442}$ See Chapter Seven

${ }^{443}$ Jeffries, 'O.E.G.' A Biography of Sir Oliver Ernest Goonetilleke, pp 127-128

${ }^{444}$ Wilson, "The Role of the Governor-General in Ceylon”, p 209

${ }^{445}$ Nira Wickramasinghe, Sri Lanka in the Modern Age - A History of Contested Identities, London: C. Hurst \& Co, 2006, p 273
} 
Colonial Office Mandarin inquisitively commented on the exceptional circumstances surrounding the proclamation:

Normally, in such circumstances, the declaration of a state of emergency, vesting executive powers in the Crown, as represented by the Governor-General, is made on the advice of ministers, and the ministers then proceed to manage the situation under the special powers delegated back to them by the GovernorGeneral. But, in this case, the Prime Minister did not, either on the afternoon of May 27 or during the next few days, raise the question as to who should handle the emergency or give any sign of being ready to do anything about it ... [H]e never gave his reasons for creating a situation in which the Governor-General became the virtual ruler of Ceylon... ${ }^{446}$

Bandaranaike perhaps realised looking back that the State of Emergency during the hartal strikes of 1953, with its mass violence and arson, had compelled Dudley Senanayake to resign due to his inability to cope with the riots and the resulting personal opprobrium that stuck to him. Whatever the political machinations, the champion of Sinhala nationalism, Bandaranaike, consciously abdicated his powers and prerogatives as Prime Minister since as Goonetilleke restrainedly admitted 'he owed his position to a majority of Sinhalese votes cast a general election ran the risk of losing his place in public life', which the unelected resident of Queen's House did not face. ${ }^{447}$

A more critical account believes Bandaranaike was greatly responsible for the crisis as he had been 'seeking to manipulate parochial sentiments for personal gain since the late 1930s, and his actions since becoming Prime Minister had betrayed a particularly dangerous naïveté. He was naïve in thinking that his communalist election campaign would not generate invidious expectations among extremists and, when they then arose, in assuming that hesitation and inaction would not inflame them. He was naïve in squandering his authority and above all, in his "kid gloves" response to dangerous provocations. ${ }^{448}$ The burden or opportunity had fallen on the Governor-General who wasted no time in assuming direct management of the crisis and invoked the powers of what had been thought to be the honorific "Commander-in-Chief" aspect of his office.

\footnotetext{
${ }^{446}$ Jeffries, 'O.E.G.' A Biography of Sir Oliver Ernest Goonetilleke, pp 128-129

${ }^{447}$ Jeffries, 'O.E.G.' A Biography of Sir Oliver Ernest Goonetilleke, p. 130

${ }^{448}$ Manor, The Expedient Utopian, p 294
} 
As the colourful account of the journalist Tarzie Vittachi records the protagonist proconsul:

... sitting at a desk with six telephones and papers on it. He held a telephone to each ear. He did not even look up as we [the press] entered. We stood inside the door as he told the mouthpiece of one telephone - 'sh-sh-sh-shoot them.' That settled, he cradled that telephone and said into the mouthpiece of the other: 'O.E.G. here. Clear them out even if you have to sh-sh-sh-shoot them.' [Goonetilleke then answered the journalist's questions on the severity of the censorship and explained that such measures as detention without trial, suspension of habeas corpus and no bail were part of the Emergency Regulations.] 'By this time not even the most obtuse among us needed a diagram to know which way things were going. But Sir Oliver couldn't resist making the point clear by telling us: 'Gentlemen. One favour. One personal request. When you report the news in future please don't say that I am running the sh-sh-show. I don't want all kinds of jealousies to come up you know ... That made it official. Sir Oliver was running the show. ${ }^{449}$

Regardless of personalities and domestic circumstances, the reality was that constitutionally the locus of power had moved from Temple Trees to Queen's House this position was contrary to Westminster practice and precedents and the Prime Minister's abnegation represented 'a complete misunderstanding of the constitutional situation ... and without precedent in the recent history of constitutional government of this country or of the United Kingdom' ${ }^{450}$ Soulbury and Goonetilleke were able and took in this critical era the discretion and powers available to them in the constitution much further than envisaged by Westminster and British standards. Arguably they harked back to the colonial era, when as one crown servant commented at the time, when the "powers of the Governor constitute a "paternal despotism", modified only by the distant authority of the Queen'. ${ }^{451}$ As one South Asian expert has argued, such actions from the office of the Governor-Generalship were shaped by the activist 'autocratic traditions of the colonial governorship out of which it had evolved' ${ }^{452}$, while

\footnotetext{
${ }^{449}$ Vittachi, Emergency '58, pp 70-72 - This book itself was initially banned in Ceylon at the time of the "Emergency", which led to its publication in London.

${ }^{450}$ Wilson, "The Governor-General and the State of Emergency, May 1958 - March 1959", pp 166-167

${ }^{451}$ Sir James Emerson Tennent, Ceylon - An Account of the Island Physical, Historical and Topographical, Vol. II, First Published 1859, $6^{\text {th }}$ edition, Colombo: Tisara Press, 1977, p 680

${ }^{452}$ Manor, The Expedient Utopian, p 297
} 
other specialist scholars have noted that it had become an 'established principle that under the Ceylon Constitution, the Governor-General is the authority in command of the armed forces at least in emergency. His position here is unlike that of his counterparts in other Commonwealth countries...' due to the latitude allowed to the holder in the constitution. $^{453}$

However, the Prime Minister ultimately has the power over the Governor-General's powers. Lord Soulbury remarked long after retiring as the Queen's Representative in Ceylon that 'under a constitutional monarchy the Prime Minister of a Commonwealth nation is more powerful than he would be in a Republic under a President. If for any reason he wishes the Governor-General to be removed he has only to request the British Sovereign to recall him, and his request must be granted showing the insecurity of the office and lack of horizontal accountability. A President however, is usually elected for a term of years, and though he may be uncongenial or uncooperative cannot be removed speedily or without a possible political upheaval' ${ }^{454}$ This was not solely his interpretation - other Prime Ministers have believed this and even his predecessor, Dudley Senanayake, who as we have seen had reason to be well disposed to Soulbury, argued in the House of Representatives that one Prime Minister could not 'tie down a future Prime Minister to the same Governor-General' and continued that in his opinion a Governor-General could carry on for fifty years or a day if the prime ministers in office thought fit. ${ }^{455}$ Ceylon and later Sri Lanka's flux and instability at the executive level and the blurred levels of accountability would prove disastrous in dealing with the country's conspicuous ethnic tensions.

\footnotetext{
${ }^{453}$ Wilson, "The Role of the Governor-General in Ceylon", p 205 and S.A. De Smith, The New Commonwealth and its Constitutions, London: Stevens \& Sons, 1964, pp 81-82

${ }^{454}$ Soulbury, "I Remember Ceylon" cited in Wilson, "The Role of the Governor-General in Ceylon", p 195

${ }^{455}$ Wilson, "The Role of the Governor-General in Ceylon", p 196. For instance Sir Oliver's term as Governor-General abruptly ended in 1962 when his name was mentioned in connection with the abortive coup d'état of that year against Mrs. Bandaranaike's Government by senior officers from the armed services and even Buckingham Palace was consulted on the termination - see Wilson, "The Role of the Governor-General in Ceylon”, p 202
} 


\section{Communalism: A 'Canker' Ignored?}

Few historians, political scientists or politicians ever imagined the vista of divisionary ethnic violence and rancour that has beset Sri Lanka with hectoring severity and international prominence for the past two decades, and which at present sadly shows little sign of subsiding. The President of Sri Lanka, addressing the United Nations in 1998 - 50 years after independence - noted on the country's ethnic conflict between the Sinhalese majority and Tamil minority that "we have failed in the essential task of nation building, ${ }^{456}$ And yet rather incongruously the Sri Lankan people enjoyed generous social welfare provisions in the country's early years and right up till the 1980s, which allowed 'high rates of literacy, longevity, and good health, more akin to those found in the developed world'. ${ }^{457}$

The failure, unlike India, to deal with communalism in this critical juncture period when the issue was manageable is a sad example that had unforeseen consequences. Politically, most observers have been struck by the generally peaceful and legal alternation of power between the two main parties and a healthy turnout from the electorate to deliver or depose a government through the ballot box. However it is communalism that is the undoubted paramount issue that all Sri Lankan governments must contend and the resulting hostility has paralysed political and social progress, and it is this issue that is indelibly etched into Sri Lanka's international image. The issue in the 1940s and earlier was mercifully bereft of bloodshed, but nonetheless was a critical juncture on which in many ways the prospect and attainment of independence hinged.

The inability of Ceylonese governments in the first ten years to deal effectively with communalism, especially by utilising some form of federalism or institutional guarantee to minorities had a ratchet effect ${ }^{458}$ for later years when such options were not so easily

\footnotetext{
${ }^{456}$ Cited from Neil De Vota, "Control Democracy, Institutional Decay, and the Quest for Eelam: Explaining Ethnic Conflict in Sri Lanka”, Pacific Affairs, Vol. 73, No. 1, Spring 2000, p 55

${ }^{457}$ Amita Shastri, "Government Policy and the Ethnic Crisis in Sri Lanka", in Michael E. Brown and Sumit Ganguly (ed.), Government Policies and Ethnic Relations in Asia and the Pacific, Cambridge, Massachusetts: MIT Press, 1997, p 129

${ }^{458}$ A term commonly employed by path dependent theorists. See Paul Pierson, "The Study of Policy Development", Journal of Policy History, Vol. 17, No. 1, 2005 pp 34-51 and Evelyn Huber and John
} 
available to deal with ethnic divisions. The political leaders of this era showed a remarkable ignorance of communalism as a serious issue and with their commitment to short-term political benefit allowed communalism, bereft of real power-sharing strategies or institutional and constitutional accommodation, to fester and later reach almost uncontrollable levels of state management. This era is therefore a critical juncture period in Sri Lankan history when the short-term decisions taken or not taken by Ceylonese leaders long-term had path dependent consequences that would make communalism the biggest issue facing Sri Lanka.

The issue of communalism dominated the debate on the constitution. D.S. Senanayake was able through his moderateness, diplomacy and grasp of the initiative able to convince his varied countrymen of the need for a united stance to gain sovereignty from the British. Most of the Tamil and other minority elites were appeased and persuaded by Senanayake's argument in 1945: 'Do you want to be governed from London or do you want, as Ceylonese, to help govern Ceylon? ${ }^{459}$ In a debate on ethnic distribution of seats he buoyantly claimed that 'I don't care if they're all Tamils, provided they are elected as Ceylonese'. 460

Indeed, except in high rhetoric and political expediency the elites of all the communities which dominated the political arena had worked well together. As K. M. De Silva has argued, for the outsider Sri Lanka in 1948 was in contrast to the "contemporary catastrophes in the rest of the former British possessions in South Asia...an oasis of stability, peace and order'. The biggest issue of communalism, which eclipsed all other political issues, seemed solved with the fiery and eloquent leader of the Tamil Congress, G.G. Ponnambalam's entrance into the first Senanayake cabinet, but this was not an institutional solution. ${ }^{461}$ Even before independence it was only on constitutional questions with implications for government where sharp communal lines formed within the elites in the State Council. Indeed, two recognised Sri Lankan scholars, one Sinhalese and the other Tamil, concluded that voting on most other issues in the 192146 period seldom produced clear communal divisions within the State Council and

Stephens, Development and Crisis of the Welfare State: Parties and Policies in Global Markets, Chicago: University of Chicago Press, 2001

${ }^{459}$ Robert N. Kearney, Communalism and language in the politics of Ceylon, Durham, North Carolina: Duke University Press, 1967, p 38

${ }^{460}$ Cited in Sir Ivor Jennings, "D.S. Senanayake and Independence", The Ceylon Historical Journal, D.S. Senanayake Memorial Number, Vol. V, Nos. 1,2,3 \& 4, July \& October 1955 and January \& April 1956, p 18

${ }^{461}$ De Silva, A History of Sri Lanka, pp 600-601 
therefore had relatively weak communal tension. ${ }^{462}$ Until 1931 Ceylon's legislative bodies had always recognised communal representation for the varied communities resident on the island, including Europeans.

\section{Colonial Questions and Answers}

However, the Donoughmore Commission admitted that 'not only is the population not homogenous, but the diverse elements of which it is composed distrust and suspect each other. It is almost true to say that the conception of patriotism in Ceylon is as much racial as national and that the best interests of the country are at times regarded as synonymous with the welfare of a particular section of its people'. Despite such an admission, the Commission saw communal representation as a canker on the body politic ... poisoning the new growth of political consciousness and effectively preventing the development of a national or corporate spirit'; it reaffirmed that there could be "no hope of binding together the diverse elements of the population in a realisation of their common kinship and an acknowledgment of common obligations to the country of which they are all citizens so long as there is communal representation, with all its disintegrating influences, remains a feature of the constitution' ${ }^{463}$

The Donoughmore Constitution's abolition of communal representation, in spite of considerable local opposition and consternation, was true to the traditional Westminster way. Ironically, the very act of eradicating communal representation catalysed communalism as a political force. Whatever the date of the beginning of active communalism, the Donoughmore Constitution did not exterminate the issue or cause the national unifying political consciousness that it hoped to. This hope of a national corporatist spirit, rather than narrow social and sectional interests, was essentially a Western British conception that was happily subscribed by the numerically insignificant Ceylonese elite. Indeed the 'rural masses understood best the language of religion, race and culture; Western style nationalism was to them an alien concept. On the other hand, an all-inclusive nationalist movement, such as the one that emerged in Ceylon ... was

${ }^{462}$ S. Namasivayam, The Legislatures of Ceylon, 1928-1948, London: Faber \& Faber, 1951, pp 60-67 and I. D. S. Weerawardana, Government and Politics in Ceylon, Colombo: Ceylon Economic Research Association, 1951, p 139

${ }^{463}$ Donoughmore Report, Cmd. 3131, pp 18-39 
both artificial and ephemeral. It was not broad-based; instead it was confined to a narrow class of Western-educated gentry'. ${ }^{464}$

It was this Ceylonese elite that dominated the political landscape and were drawn from all the communities. And it was this Sinhalese dominated inter-communal elite that were the sole channel to Westminster and to whom independence was delivered. The indigenous elite and the departing British official and their masters in Whitehall crucially rejected what they saw as the parochial atavisms that the communally minded masses held. They were unrepresentative of their communities. They naïvely calculated that the ad hoc community compact reached on gaining independence would create a civic nationalism, which would spell the subordination of sectional identity.

The new oligarchy that succeeded the colonial power, euphoric at gaining independence, did not acknowledge the changing sensitivities of the society it now administered. It had striven for independence for all the country so that all could be equal with no need to pay allegiance to any foreign power-swapping the durbar for democracy. Exhilarated by the heady ideals of western democracy and its veneration of individual liberty, its leaders rejected the stagnant, divisive and archaic structure of the old native society. Independence, to their minds, would enable their society to enter a new Elysian era. But the modernisation of native political power generated its own tensions. The process of forming the new state stimulated parochialism, communalism and ethnic rivalry as groups competed for their share of the prize of sovereignty. ${ }^{465}$

The Westminster urge for a secular constitutional framework was blind to the prevalent pluralism of Ceylon, which was buttressed by the local elite. In most New Westminsters of the time, such as Australia, South Africa, Canada and India, there had been some form of federal adaptation. However, the Ceylonese leaders showed blindness to such examples by thinking they could deal with their divisive polity purely by their leadership, preferring the centralised and unitary British Westminster as their model. The fragile compromise between Sinhalese and Tamil leaders was 'based on certain implicit premises: the concept of a secular state in which all religious groups enjoyed

\footnotetext{
${ }^{464}$ Chandra R. de Silva, "Sinhala-Tamil Ethnic Rivalry: The Background", in Robert B. Goldmann and A. Jeyaratnam Wilson (ed.), From Independence to Statehood - Managing Ethnic Conflict in Five African and Asian States, London: Frances Pinter, 1984, p 112

${ }^{465}$ Harshan Kumarasingham, "A Democratic Paradox: The Communalisation of Politics in Ceylon 19111948”, Asian Affairs, Vol. 37, No. III, November 2006, p 348
} 
equal rights, and the gradual replacement of English as the official language by Sinhalese and Tamil. Equal opportunities for both communities would thus be provided' ${ }^{466}$ The cracks in this delicate unity widened when those elites in executive power showed complacency, insensitivity, or even ignorance of the growing tensions of their young democracy. The system of democracy implanted to Ceylon activated the existing community stresses. Nina Samarasinghe demonstrates that as independence dawned, few of the elite in power 'had perceived or were willing to perceive the complex nature of the Ceylonese polity ... The minorities would, it was thought, accommodate to a measured Sinhalese majority domination over the country. British officials shared the same delusion'. ${ }^{467}$

This "delusion" existed and persisted despite evidence to the contrary. The Donoughmore Commission, which had introduced universal suffrage to the island, which incidentally was opposed by almost all members of the State Council ${ }^{468}$, though able to constitutionally abolish communal representation, could not abolish communalism itself. When the Soulbury Commissioners arrived in 1944 they, though seeing the agreed failure of the previous constitution to enliven a national polity, did little to constitutionally or institutionally answer the concern of communalism and instead hid behind the closed window of British Westminster. The implantation of a cabinet-dominated British Westminster unitary not federal parliamentary model with its accompanied single member first-past-the-post majoritarian electoral system paid distressingly slight heed to local conditions. Even the London Times declared accurately that the Soulbury Commission's treatment of the very serious communal issues in Ceylon was 'unimaginative'. ${ }^{469}$ This was as much to do with the narrow nature of the Soulbury Commission's deliberations. One political scientist characterised the process that brought the independence constitution as one that:

... did not come out of a broad-based process of negotiation and bargaining between the various ethnic groups on the island. Instead, it was based on discussions between the departing colonial administrators and the Sinhalese elite

\footnotetext{
${ }^{466}$ De Silva, "Sinhala-Tamil Ethnic Rivalry: The Background", pp 116-117

${ }^{467}$ Nina Samarasinghe, Colonial Policy, Ethnic Politics and the Minorities in Ceylon 1927-1947, London: Oxford University Press, 1989, pp 341-342

468 'Almost to a man they [the elite State Council] had opposed the introduction of universal suffrage. They were extremely reluctant to extend any of the very considerable powers which they enjoyed at the national level to people outside their immediate circle'. Manor, "The Failure of Political Integration in Sri Lanka (Ceylon)", p 24

${ }^{469}$ Wickramasinghe, Sri Lanka in the Modern Age, p 168
} 
represented by D.S. Senanayake and the all-Sinhalese Board of Ministers. The first Sri Lanka Tamil joined the Board ... at a very late stage in the negotiating process. The negotiations were dominated by Senanayake ... and no other body was invited to participate in formulating constitutional proposals. Issues of particular concern in a multiethnic state - such as citizenship, franchise, and individual and group rights - were not discussed or agreed to by representatives of the country's largest ethnic groups. The issue of citizenship was left unresolved by the British as a concession to Senanayake. Tamil protests were characterised as acts that would delay or obstruct "Ceylon's march to freedom". 470

Communalism was a dirty word in Westminster and as such was almost completely ignored in constitutional form and literature. Sir Frederick Rees, one of the Commissioners, commenting that Donoughmore had abolished communal representation for territorial representation in a unitary state, admitted that the earlier Commission did not fully realise 'the effect of a Western idea on a traditional structure'. Nonetheless, the Soulbury Commission rejected not only the Tamil Congress proposal for guaranteed representation for minorities, but also proposals from minority groups as diverse as the Ceylon Moors' Association, the All-Ceylon Scheduled Castes' Federation, the Catholic Union of Ceylon, the Ceylon Malayali Mahajana Sabha, the Ceylon Muslim League, the Dutch Burgher Union, the European Community and even the Central Fisheries Union of Ceylon, who all with different advocacy and method argued for separate and constitutionally provisioned representation in parliament. ${ }^{471}$

The new constitution, which resulted from the Soulbury negotiations with its 'negotiated non-autochthonous nature', with its elite espousal of western forms of democracy, rejection of communal issues, and absence of the mass struggle that established India's leadership, naturally 'did not capture the national imagination'. ${ }^{472}$ The new constitution succeeded in establishing a generic majoritarian Westminster system that assumed that the minority were numerically large enough to resist dominance from the majority and yet the majority community could easily, and did, dominate in the post-independent era especially with the simple legal

\footnotetext{
${ }^{470}$ Shastri, "Government Policy and the Ethnic Crisis in Sri Lanka", p 136

${ }^{471}$ Rees, "The Soulbury Commission 1944-45", pp 31-36

${ }^{472}$ Coomaraswamy, Sri Lanka - The Crisis of the Anglo-American Constitutional Traditions in a Developing Society, p 13
} 
disenfranchisement of 900,000 Indian plantation workers. The 'classic Westminster model' in Ceylon with its aversion to ethnic realities left few guarantees to stem fears or promote power sharing. Indeed after 1956, Sinhalese dominated governments were able with their two-thirds majority to simply override the constitution as if to prove the Soulbury Constitution's assumptions wrong and realise minority fears. ${ }^{473}$ The system, as one constitutional scholar argues, was founded 'assuming the possibility of communal harmony without supportive institutional processes ... and did not recognise indigenous structures'. ${ }^{474}$

One of the potential avenues for institutional protection of minorities was through the Soulbury-established thirty-member Senate. The Governor-General was empowered by the Constitution to appoint Members to the Senate who had 'rendered distinguished public service or be persons of eminence in professional, commercial, industrial or agricultural life, including education, law medicine, science, engineering and banking' rather than on community lines. ${ }^{475}$ This meant in effect that it was rather more like Britain's 'dignified' unelected and patronage filled House of Lords than a representational assembly to hold the executive to account. One of the few changes from the Soulbury Recommendations the 1947 constitution was the removal the Governor-General's power of appointing Senators at 'his discretion', which would have enabled the Head of State to potentially appoint minority Senators as Moore had hoped and quell minority fears. Instead the amended subsection in the 1947 constitution stipulated that the Governor-General's powers of selection 'should be exercised on advice', which in Westminster system translates, as Sir Ivor Jennings concedes, to the reality that 'the Prime Minister now advises appointments' ${ }^{476}$

Similar expectations concerned the Governor-General's ability to appoint six nominated members to the House of Representatives. The Soulbury Recommendations hoped that these members would primarily secure representations of Burghers and Europeans, communities that would struggle to win an electorate seat. Section 11 (2) of the original Order in Council in 1946 stated that the Governor-General could appoint new members

\footnotetext{
${ }^{473}$ Radhika Coomaraswamy, Ideology and the Constitution - Essays on Constitutional Jurisprudence, Delhi: Konrak Publishers, 1997 p 19, Wickramasinghe, Sri Lanka in the Modern Age, p 169 ; de Silva, "Sinhala-Tamil Ethnic Rivalry: The Background", pp 117-118 and Coomaraswamy, Sri Lanka - The Crisis of the Anglo-American Constitutional Traditions in a Developing Society, $\mathrm{p} 11$

${ }^{474}$ Coomaraswamy, Sri Lanka - The Crisis of the Anglo-American Constitutional Traditions in a Developing Society, pp 14-15

${ }^{475}$ I.D.S. Weerawardana, The Senate of Ceylon at Work, Colombo: Ceylon University Press, 1955, pp 2-3

${ }^{476}$ Jennings, The Constitution of Ceylon, p 180
} 
'after every general election to represent any important interest in the Island which is not represented or is inadequately represented', which seems to indicate discretion and initiative to the Governor-General. In 1954 this was amended and published in the Gazette to read that if after an election the 'Governor-General is satisfied that any important interest in the Island is not represented or is inadequately represented, he may appoint any persons, not exceeding six in number, to be Members of the House of Representatives'. ${ }^{477}$ The key phrase 'in his opinion' was replaced by 'satisfied' to leave less personal discretion at the Governor-General's hands. Instead the amended section as Jennings again clarifies 'is quite general and leaves the Prime Minister the discretion of advising the appointment of Members'. ${ }^{478}$

The Senate was one of the few recommendations that the Sinhalese dominated Board of Ministers did not approve, seeing it as unnecessary and controversial. ${ }^{479}$ Perhaps due to this the Senate never performed any major constitutional role except as a place of patronage. Prior to its establishment minorities had the 'belief that it would effectively safeguard minority interests, a view which later events would prove wrong' and was an ineffective institutional check. ${ }^{480}$ Anyway the Soulbury Report wanted a traditional Westminster upper house made up of eminent people not sectional and 'hope[d] that the element of communal representation will not figure largely in the composition of a Second Chamber'. ${ }^{481}$ The Senate had no difficulty in passing the controversial communal legislation of the era and there were few tears at its abolition in 1972 when the country became a Republic. ${ }^{482}$

In complete contrast to India but in harmony with British Westminster practice there was no Bill of Rights that could have allayed minority concerns. The majoritarian Westminster executive's actions were to be only counselled by an independent judiciary and section 29 (2) of the Constitution, which prohibited discrimination on religious or community grounds. ${ }^{483}$ And yet it when it was tested for example in 1953 once the Indian Tamils appealed their disenfranchisement to London as Ceylon retained the Privy Council as its highest court, the Privy Council ruled that this 'did not conflict with

\footnotetext{
${ }^{477}$ Cooray, "Operation of Conventions in the Constitutional History of Ceylon, 1948 to 1965", pp 18-19

${ }^{478}$ Ceylon Constitution, Section 29 (2) in Jennings, The Constitution of Ceylon, p 181

${ }^{479}$ Rees, "The Soulbury Commission 1944-45", pp 31-36

${ }^{480}$ Namasivayam, Parliamentary Government in Ceylon, 1948-1958, pp 44-46

${ }^{481}$ Soulbury Report, Cmd. 6677, p 79

${ }^{482}$ See B.C.F. Jayaratne, “Abolition of the Senate of Ceylon”, The Parliamentarian - Journal of the Parliaments of the Commonwealth, Vol. LIII, No. 2, April 1972, pp 104-112

${ }^{483}$ Ceylon Constitution, Section 29 (2) in Jennings, The Constitution of Ceylon, pp 200-201
} 
the non-discrimination clause, Section 29 (2)' since the Law Lords believed it was the Government's right to determine who and what constituted a community even though the Indian Tamils had been considered a community or race since at least the 1911 census. ${ }^{484}$ A Bill of Rights was seen as highly unnecessary since the British (and importantly Jennings) and the local elite believed that Ceylon 'would abide by the customs and conventions which had developed in Britain through practice and the common law to safeguard those rights' ${ }^{485}$ As has been argued:

... this proved an oversimplification of the problems that faced modern Sri Lanka. Its democratic and constitutional structures were ill-equipped to adapt to the divisive consequences of a multi-ethnic society with its pressures of regionalism, religion and especially language. The elite of Senanayake's ilk would only be able to stem the tide of ethnic nationalism for so long, even though they believed they had secured independence for all and presided over the first years of prosperity and peace. The elites' brand of secular nationalism proved incapable of gaining widespread support and reaching the lower strata of society. Here the real loyalty lay with kith and kin-an ethnic rather than national identity. Secular nationalism was elitist in conception. The elite and the British were unable to create a new political culture to acquaint average citizens with the demands and responsibilities of a pluralist democracy. ${ }^{486}$

The British and their implanted constitution, with its inability to marry Western conceptions with Eastern realities, relied on the good will of the Senanayake leadership to maintain peace and harmony with the minorities, without the need for explicit constitutional safeguards. Though this generally proved correct, subsequent governments and Prime Ministers and later still Presidents were under no such obligation as was later proved. Senanayake had argued with the Colonial Office during the negotiations for independence that only 'once the constitutional question is settled, communal questions will cease to be relevant'. ${ }^{487}$

\footnotetext{
${ }^{484}$ Wickramasinghe, Sri Lanka in the Modern Age, p 174

${ }^{485}$ Coomaraswamy, Ideology and the Constitution - Essays on Constitutional Jurisprudence, p 20

${ }^{486}$ Kumarasingham, "A Democratic Paradox", pp 354-355 and see K. M. De Silva, Managing Ethnic Tensions in Multi-Ethnic Societies: Sri Lanka, 1880-1985, Washington, D.C.: University Press of America, 1986, p 156

${ }^{487}$ Letter from Mr Senanayake to Mr Hall, 16 August 1945 in British Documents on the End of Empire, Series B - Sri Lanka, Part II, Towards Independence 1945-48, p 39
} 
This proved to be either a political prevarication to gain concessions or a naïve and disastrous expectation. The constitutional infrastructure was not evident enough to relieve minority fears or secure their prominent participation and representation in the executive and legislature. Continuing his exposition in late 1945, Senanayake stressed with comparison and conjecture that 'nor can communal divisions be regarded as an argument against Dominion status. They have not prevented the offer of that status to India, where they are much more important' ${ }^{488}$ But the Indian comparison can only stretch so far since, as was discussed in the Indian chapters, the Indian leadership and constitution recognised the plurality of their polity and established constitutional and political mechanisms such as the establishment of federated states based on linguistic and ethnic lines and a Bill of Rights to accommodate such distinctions.

\section{The Ponnambalam Critique}

The main proponent of an alternative view was the Tamil Congress leader G.G. Ponnambalam. The noted Tamil orator, known as the 'pocket Demosthenes ${ }^{489}$ outlined his argument to the Colonial Secretary in November 1945 for 'balanced representation'. Ponnambalam believed, as did other minority leaders, that the proposed Soulbury Constitution with its basis on territorial representation, which would encourage communalism rather than end it and would give the Sinhalese 'an overwhelming proportion of electoral power, even more than their numbers would warrant, and reduce all the other communities severally and collectively to political impotence' and had 'failed to devise a scheme of representation of its own which would prevent the permanent enthronement of a racial majority in the seat of power' ${ }^{490}$ Ponnambalam critiqued the British Westminster carbon copy since Ceylon was to him not England: 'In England by reason of a common nationality, common political traditions and a common language, population is a satisfactory basis of representation; but in a country like Ceylon with the population divided by every form of heterogeneity, this basis of representation will lead to a negation of representative government' ${ }^{491}$

The solution in the Ponnambalam's mind was that the 'major community should be given a relative majority and not an absolute majority in the Legislature'. This would in

\footnotetext{
${ }^{488}$ Letter from Mr Senanayake to Mr Hall, 16 August 1945 in British Documents on the End of Empire, Series B - Sri Lanka, Part II, Towards Independence 1945-48, p 39

${ }^{489}$ Manor, The Expedient Utopian, p 131

${ }^{490}$ Letter from Mr G.G. Ponnambalam to Mr Hall, 3 November 1945 in British Documents on the End of Empire, Series B - Sri Lanka, Part II, Towards Independence 1945-48, pp 143-146

${ }^{491}$ Letter from Mr G.G. Ponnambalam to Mr Hall, 3 November 1945 in British Documents on the End of Empire, Series B - Sri Lanka, Part II, Towards Independence 1945-48, p 148
} 
effect mean "fifty-fifty" representation with the Sinhalese having half the seats and the rest filled by the minorities and mean in his belief that the Sinhalese would be 'deprived of a primary motive to perpetuate communalism' and end their potential 'domination' as a 'permanent racial majority [that was] unalterable by any appeal to the electorate'. Ponnambalam questioned why Ceylon's minorities received no 'weightage in representation' when this principle in plural societies has been accepted by 'His Majesty's Government' in respect to the French Canadians under the Act of Confederation of North America, 1867, Muslims in Cyprus, Māori in New Zealand and Muslims, Sikhs, Christians and others under the Government of India Act 1935 and elsewhere in the Empire. ${ }^{492}$

The Cambridge-educated King's Counsel did not leave his analysis to be focussed purely at the Legislature; he also contended that the executive strata could be the most dangerous, with Ceylon's nascent polity and political juvenility exhibited in respect to party and mass participation. Ponnambalam feared that the proposed structure left unaltered would mean that the 'very apex of the Executive pyramid in the scheme accepted by the Commission is the Prime Minister who is without the check of a party system, but with the obvious backing of a pliant Sinhalese majority'. The Prime Minister would have 'unfettered control' in the choice of ministers, allocation of portfolios and the power to 'demand a dissolution on the threat of an adverse vote. Such conditions, Ponnambalam speculated, would mean a Prime Minister could become a 'communal dictator', with all ministers from the same racial group and all powerful since there would not be an effective opposition. ${ }^{493}$

Once again Ponnambalam's answer was to have mandatory balanced representation 'composite cabinet'. Ponnambalam rebuked the Soulbury Commission admission that the Cabinet should have minority representatives for not giving any method or formality of achieving this. 'In the circumstances of Ceylon minority representation in the Cabinet cannot be left to convention as in Canada or Switzerland' Ponnambalam argued and contended that 'only a mandatory provision in the Constitutional Instrument reserving for the minorities a specific proportion of the portfolios on equitable lines can secure for them this vital right'. The Cabinet should 'reflect the composition of the

\footnotetext{
${ }^{492}$ Letter from Mr G.G. Ponnambalam to Mr Hall, 3 November 1945 in British Documents on the End of Empire, Series B - Sri Lanka, Part II, Towards Independence 1945-48, pp 148-149

${ }^{493}$ Letter from Mr G.G. Ponnambalam to Mr Hall, 3 November 1945 in British Documents on the End of Empire, Series B - Sri Lanka, Part II, Towards Independence 1945-48, p 152
} 
legislature' and Ponnambalam sought this implementation by i) the Prime Minister being elected by the House and thus enjoying its confidence ii) ministers being elected by the House on a system of proportional representation by means of the single transferable vote and iii) ministers from the minorities being selected by them in the first instance. ${ }^{494}$ After explaining the inadequacy of constitutional protection against discrimination and judicial infectivity, the controversial but erudite politician concluded that the Westminster assumptions were based on flawed ideals since the previous and current Commission supposes that:

... all the conditions and prerequisites ... thought ... necessary for the successful functioning of English Parliamentary institutions are still non-existent. It professes to appreciate the difficulty of applying the principles of Western Democracy to Ceylon. It also admits that the prospect of transplanting British institutions to Ceylon with success may appear remote. Nevertheless because it fears that modifications of the British form of Government may not prove any more successful it recommends for Ceylon a method of Government of which it "knows something about" and which is a "result of very long experience". The obvious reply to this is that the British method of Government of today is the result of the experience of centuries of its working by the British people and adapted to their particular genius. To recommend such a Constitution for Ceylon in the face of the experience of the minorities for the last fourteen years in the anticipation that certain hopes and expectations will be realised will amount to the handing over of the future welfare of a large section of the people of the Island to the unfettered control of a permanent communal majority. ${ }^{495}$

The Westminster constitution for Ceylon acted essentially as a facsimile of Britain's with minimal modification. As one recent Sri Lankan scholar has written of this implantation had crucial inferences for Sri Lanka's ethnic 'bifurcation':

From the point of view majority-minority relations this British modular form of the constitutional state had the following implications. Firstly, the state was fashioned as a unitary one with centralisation of legislative, executive and

\footnotetext{
${ }^{494}$ Letter from Mr G.G. Ponnambalam to Mr Hall, 3 November 1945 in British Documents on the End of Empire, Series B - Sri Lanka, Part II, Towards Independence 1945-48, pp 153-154

${ }^{495}$ Letter from Mr G.G. Ponnambalam to Mr Hall, 3 November 1945 in British Documents on the End of Empire, Series B - Sri Lanka, Part II, Towards Independence 1945-48, p. 157
} 
judicial functions of the state. Any measure of decentralisation was to be found only within the system of local government. Secondly there was no Bill of Rights or a Fundamental Rights Chapter in the Constitution. Thirdly, and linked to the second was the absence of explicit provision for judicial review of legislation. $^{496}$

However, the British Westminster way was seen as the only way and the Soulbury Constitution and most local senior political leaders were 'quite pleased with the centralised majoritarianism inherent in representative democracy, ${ }^{497}$ Despite the social heterogeneity, lack of political party system, rising communalism, and substantively elitist conception of the state in contrast to the masses' ignorance of western democracy, the Soulbury Commissioners adamantly believed that 'Ceylon [was] well qualified for a Constitution framed on the British model'. 498

Ponnambalam's advocacy generally fell on deaf ears. Soulbury himself informed the Colonial Secretary that the Commissioners, on the Tamil Congress leader's claim for balanced statutory representation, 'found themselves quite unable to agree to that' ${ }^{499}$ Ponnambalam also refused to budge on "fifty-fifty" even when liberal Sinhalese State Councillors offered 60:40. An authoritative scholar on the subject believes that his intransigence stemmed from his 'unquestioned faith in the imperial government' and that 'Whitehall would stand by him' over the heads of Senanayake and the Soulbury Commissioners. $^{500}$ Instead Whitehall, as explained above, listened to Soulbury, Jennings and Senanayake and entrusted power essentially to Senanayake as was their policy in places such as India, Pakistan, Malaya and Ghana. Though unquestionably a successful leader of the Tamils he by no means represented the panorama of Tamil opinion. Old elite Tamils like Sir Arunachalam Mahadeva and others of similar ilk, comforted by their fellow cross-communal grandees supported Senanayake and his overtures, while others like future Federal Party leader, S.J.V. Chelvanayakam, thought Ponnambalam more interested in merely integrating Tamil with the Sinhalese and a sectionalist not a Tamil nationalist.

\footnotetext{
${ }^{496}$ Jayadeva Uyangoda, Questions of Sri Lanka's Minority Rights, Colombo: International Centre of Ethnic Studies, 2001, p 38

${ }^{497}$ Uyangoda, Questions of Sri Lanka's Minority Rights, p 23

${ }^{498}$ Soulbury Report, Cmd. 6677, p 51

${ }^{499}$ Letter from Lord Soulbury to Mr Hall, 5 October 1945 in British Documents on the End of Empire, Series B - Sri Lanka, Part II, Towards Independence 1945-48, p 112

${ }^{500}$ A. Jeyaratnam Wilson, Sri Lankan Tamil Nationalism - Its Origins and Development in the $19^{\text {th }}$ and $20^{\text {th }}$ Centuries, London: Hurst \& Company, 2000, p 72
} 
Ponnambalam was viewed as 'an opportunist' who was seen after serving under Senanayake as 'someone who would serve another Sinhalese Prime Minister to strengthen his own political power'. ${ }^{501}$ Ponnambalam, mesmerised by the offer of a seat in Cabinet took it gleefully, despite reservations from his northern constituents and in fact was able to gain irrigation and industrial development for the Tamil region. It also allowed him the chance he always craved of being part of and influencing national affairs rather than being purely 'cramped and cribbed' by the tapered politics of regionalism and ethnicity. ${ }^{502}$ Ponnambalam's actions and views showed that Cabinet inclusion was not for power-sharing, but for patronage accentuated by a negligible party system. Like many Tamils, Ponnambalam saw cooperation with the Sinhalese and the U.N.P. in particular as the best opportunity to achieve Tamil objectives by influencing from the centre with positions of power, while others like Chelvanayakam, who founded the Federal Party in 1949, took a more contrasting approach by seeing a more self-determinist and less centralised unitary path for the Tamils with regional powersharing aspirations.

\section{Language, Federalism and Bandaranaike - Opportunity Lost?}

G.G. Ponnambalam's greatest foe in politics was S.W.R.D. Bandaranaike and yet they were in many respects highly similar and equally capable and controversial politicians. These Oxbridge competitors wooed the legislature with their 'sparkling verbal duels' and extenuated communalism in their communities and 'found it advantageous to exaggerate the threat which the other posed'. The Governor in the late 1930s, Sir Andrew Caldecott, thought they were in some ways 'covert allies' due to their cordial personal relations, which in turn raised doubt as to their authenticity of their rhetoric that was seen by some as purely tactical to gain the support of their rural and lower class followers. $^{503}$ Interestingly, in view of his later ethnically divisive actions as Prime Minister, it was Bandaranaike who early in his political career offered a more realistic and credible view and solution to Ceylon's ethnic dilemma than Ponnambalam's narrow "fifty-fifty" scheme, which along with his appeals to the British "created an unfavourable climate for accommodation, 504

\footnotetext{
${ }^{501}$ A. Jeyaratnam Wilson, S. J. V. Chelvanayakam and the Crisis of Sri Lankan Tamil Nationalism, 19471977, London: Hurst \& Company, 1994, pp 14-20 and 46

${ }^{502}$ Wriggins, Ceylon: Dilemmas of a New Nation, p 146

${ }^{503}$ Manor, The Expedient Utopian, p 131

${ }^{504}$ Michael Roberts, "Ethnic Conflict in Sri Lanka and Sinhalese Perspectives: Barriers to Accommodation”, Modern Asian Studies, Vol. 12, No. 3, 1978, p 375
} 
Bandaranaike was one of the few politicians to assess the political reality of Ceylon's social milieu and envisaged that the British Westminster style unitary state would not cater for a plural society. In the years preceding independence he criticised the leading Ceylonese elite who saw the political vista 'along the lines of British thought unintelligently and without any considerations of the particular conditions of the country'. ${ }^{505}$ Instead Bandaranaike's early 'understanding of indigenous social realities and his willingness to reject borrowed notions permitted him to move away from the model of a single nationality nation towards a pluralist and pyramidical solution'. This was in contrast to the secularist, centralised, pan-Ceylonese nationalism subscribed to by the elite and evidenced by the British in their active disdain towards recognition of communal representation, which the Constitutions of Donoughmore eradicated and the Soulbury one readily upheld.

The problem was that there was no true nationalism sought by the British and elites because they chose to see the 'nation as a monolith rather than a federation of sections' and that nationalism was quite invisible since 'fundamentally, it was a Sinhalese nationalism. But in their own mind it was equated with an all island Ceylonese nationalism. The whole was unconsciously or consciously subsumed by the part' ${ }^{506}$ Bandaranaike realised and spoke of this in the 1940s and initially saw that the very real distinctions of the different communities could be tempered by a 'pyramid of loyalties', which 'whilst uniting the Sinhalese, [would] work for the higher unity, the unity of all communities'; one experienced social scientist attests that such an arrangement 'held out the best hopes of assuaging Sinhalese-Tamil conflict' ${ }^{507}$ Interestingly, this was not dissimilar from the theories of the All-Ceylon Tamil Conference just earlier in 1937:

The conception of corporate unity in the minds of the Sinhalese is in the nature of a merger, an absorption of the minorities in the major community. A just and more correct idea of an united Ceylon is that of a rich and gorgeous many-

\footnotetext{
${ }^{505}$ Michael Roberts, "Problems of Collective Identity in a Multi-Ethnic Society: Sectional Nationalism vs. Ceylonese Nationalism, 1900-1940”, in Michael Roberts (ed.), Sri Lanka - Collective Identities Revisited, Volume I, Marga Institute: Colombo: 1997, p 443

${ }^{506}$ Roberts, "Problems of Collective Identity in a Multi-Ethnic Society: Sectional Nationalism vs. Ceylonese Nationalism, 1900-1940”, p 443

${ }^{507}$ Roberts, "Ethnic Conflict in Sri Lanka and Sinhalese Perspectives", pp 360-361
} 
coloured mosaic set and studded with the diversities of communal consciousness within a glorious one-minded solidarity. ${ }^{508}$

Constitutionally Bandaranaike was the first major politician who provided a solution to provide and protect such pluralism. In 1926, exactly thirty years before he split the country over the language issue, he advocated in Jaffna, the political heartland of the Tamils, federalism as 'the only solution to our political problem'. ${ }^{509}$ Though federalism was and still is an issue in Sri Lanka trumpeted by and identified with certain Tamil parties, the idea gained its official genesis on the island from the upcountry Sinhalese Kandyan National Assembly in 1925. In relation to their own unique history the Assembly volunteered that Ceylon was made up of many nations and that 'the creation of a Federal State as in the United States of America ... a Federal System ... will enable the respective nationals of the several States to prevent further inroads into their territories and to build up their own nationality'. ${ }^{510}$

However, federalism never gained significant Sinhalese support, who favoured the unitary centralised system bequeathed by the British, while the Tamil political groups themselves had not seriously considered the option until after independence, instead favouring power sharing at the central executive and national legislature. Bandaranaike quickly scuttled his bold federalist solution 'when he realised that it contravened the desire of most Sinhalese ${ }^{511}$ and galvanised such populism towards the realisation of Sinhalese nationalism and concurrently its rejection and replacement of the concept of Ceylonese nationalism. This was a missed opportunity of structural and institutional accommodation over twenty years before the critical juncture of independence. The vacuum of power left by the British merely pushed the Sinhalese leaders to mimic their former masters' culture and dismiss the idea of federalism.

This despite the fact that almost all of the New Westminsters had in designing their constitutions accepted federalism, including their teeming neighbour across the Palk Strait, which had greatly helped provide a method of institutional inclusion for India's plethoric peoples. Indeed through degrees of territorial devolution, guarantees of

\footnotetext{
${ }^{508}$ Roberts, "Problems of Collective Identity in a Multi-Ethnic Society", p 456

${ }^{509}$ See K.M. De Silva, "Sri Lanka: The Bandaranaikes in the Island's Politics and Public Life Reflections on the Centenary of S.W.R.D. Bandaranaike's Birth", The Round Table, Vol. 350, 1999, p 257 and pp 278-279

${ }^{510}$ Roberts, "Problems of Collective Identity in a Multi-Ethnic Society", p 454

${ }^{511}$ Manor, The Expedient Utopian, p 62
} 
personal and individual liberty and facilitation of economic and culture intercourse India has accomplished much. In contrast, today 'it is increasingly evident that Sri Lanka's unitarism is only a military reality...[while]...Sri Lanka's much larger and potentially more fractious neighbour India has preserved its nationhood by following a federalist strategy', which has been 'successful in containing ethnic regionalism and promoting inter-ethnic cooperation', unlike its island neighbour. ${ }^{512}$

The electoral victory of a coalition led by Bandaranaike in 1956 was the great turning point not merely within our ten year focus but in Sri Lankan history. This was the first time in the post-independent era in all of South Asia that the governing party had been turned out of office by the electorate. In terms of communalism Bandaranaike's massive victory was the harbinger of government-led linguistic nationalism, which for Ceylon is synonymous with ethnic nationalism. This new Sinhalese-Buddhist nationalism rapidly brought down the curtain of secular non-sectional nationalism that elites like D.S. Senanayake had idealistically draped over the nation. Sri Lankan nationalism became Sinhalese nationalism ${ }^{513}$ and vice versa, which had the consequence of making the 'concept of a multiracial polity ... no longer politically viable' since for the majority of the country Buddhism and the Sinhalese language held greater emotive and populist appeal than the 'meaningless abstraction' of a multiracial polity, which subsequently led to the marginalisation of minorities from the institutions of state. ${ }^{514}$

Consociationalist scholars like Ian Lustick have described such situations as 'control democracy' - a situation where 'the majority group eschews ethnic compromise with a state's minorities and instead controls the levers of power', which means in the Sri Lankan case 'the attempt to create a Sinhalese ethnocracy'. ${ }^{515}$ The ethnic partnership and participatory ethos of consociationalism and its stress on accommodation would seem to hold an answer indeed 'given the plural character of Ceylonese society and its solid democratic traditions, at first sight the country seems to be a prime candidate for

\footnotetext{
512 Suri Ratnapala, "Federalism as a Response to Ethnic Regionalism" in Federalism - Comparative Perspectives form India and Australia, Ian Copland and John Rickard (eds.), New Delhi: Manohar, 1999, pp 113-114

${ }^{513}$ See K.N.O. Dharmadasa, Language, Religion, and Ethnic Assertiveness - The Growth of Sinhalese Nationalism in Sri Lanka, Ann Arbor: University of Michigan Press, 1992

${ }^{514}$ De Silva, A History of Sri Lanka, p 626

${ }^{515}$ De Vota, "Control Democracy, Institutional Decay, and the Quest for Eelam: Explaining Ethnic Conflict in Sri Lanka", p 57
} 
the emergence of some kinds of consociational politics'. ${ }^{516}$ The advent of 1956 and its electoral demolition of the U.N.P. ${ }^{517}$ and especially the promulgation of the "Sinhala Only Bill" to make Sinhalese the official language ${ }^{518}$ catalysed the ethnic polarisation to another, more dangerous level than ever before.

The possibility of consociationalist power-sharing became even more difficult with this pan-Sinhalese ministry. If there had been any doubt before, Ceylon now clearly failed in the four power-sharing elements needed for successful consociationalist political accommodation and stable democracy in divided societies - i) grand coalition governments that include representatives of all major linguistic and religious groups ii) cultural autonomy iii) proportionality in political representation and civil service appointments and iv) a minority veto with regard to vital minority rights and autonomy. ${ }^{519}$ Post-independent politics would never be the same again - all the major mass parties adopted the rhetoric of Sinhala nationalism while the Tamil parties increasingly became adversarial and isolationist. Like the lost opportunity of federalism, the inability to foster any positive, meaningful or enduring consociational partnerships between ethnic groups during the first decade was a major failing for Sri Lanka's future with path dependent consequences. As Wilson claims:

In the 1947-56 phase, the language of politics had been on two levels. On one level, the language of Sinhalese Buddhist chauvinism was used on most public platforms especially in the villages. But in Parliament, in the committee rooms, in the cabinet ... it was a sophisticated nationalism that was emphasised ... The emphasis was mainly at this level as long as the new forces remained dormant. But with the upsurge in 1956, the political diction of chauvinism set the tone for all political groupings... 520

\footnotetext{
${ }^{516}$ H. E. Chehabi, "The Absence of Consociationalism in Sri Lanka", Plural Societies, Vol. 11, Winter 1980, p 55

517 The coalition of forces under Bandaranaike's leadership commanded fifty-seven seats in the 101 seat lower House - while the U.N.P. was left with just eight members, only two of whom had been ministers. For more analysis of this crucial election see Wriggins, Ceylon: Dilemmas of a New Nation, pp 326-369 ${ }^{518}$ Originally in pre-independence times the quest had been for both Sinhalese and Tamil to be the official languages - but the populism subsequently generated by making it Sinhala only was too irresistible for many politicians.

${ }^{519}$ See Lijphart, "The Puzzle of Indian Democracy: A Consociational Interpretation”, pp 258-266

${ }^{520}$ A. Jeyaratnam Wilson, Electoral Politics in an Emergent State: The Ceylon General Election of May 1970, Cambridge: Cambridge University Press, 1975 p 23
} 
Yet an authoritative account on communalism from the late 1960s concluded that separatism, unlike today, was for the Tamils not an objective, but that their aim in fact was to work within the Ceylonese polity. Today, far from the violent secessionist tactics of the Tamil Tigers or the active discrimination and reprisals by the periodically anti-state Sinhalese J.V.P., the pre-1970s was an era when the communal struggle was more democratic. Communalism of that early era was 'fought out within the common institution of Parliament, where spokesman of both communities argue their causes within the same chambers, according to the same rules of procedure, and, although with declining frequency, often in the common language of English'. During this time there was only trivial support from Tamils for 'total political separation' and negligible thought from the Sinhalese 'to deny to the Ceylon Tamils membership in the Ceylonese polity' - though the Indian Tamils were actively excluded. ${ }^{521}$ However, the reality of the unitary Westminster-sanctioned electoral system ensured the continuity and encasement of majoritarianism and exacerbated fraught rhetoric and tension on all sides. De Votta argues that in Ceylon's implanted Westminster electoral system -

where more than eighty percent of parliamentary seats were determined by Sinhalese constituencies and Sinhalese politicians were devoid of patron-client ties to the Tamils, successive governments were able to conveniently disregard legitimate Tamil grievances; on the other hand by being dependent on Sinhalese electorates for continued governance, the governments concerned had no choice but to pander to the majority community's demands to perpetuate Sri Lanka's control democracy. ${ }^{522}$

This electoral truth has limited the scope and opportunity for any consociational cooperation. The elites that have led the two major parties are hindered in any attempt to make concessions by the fact they effectively compete for the same electorate. This has meant that despite the cleavages within the Sinhalese themselves, they can still 'get an over-all majority for one group, which one might call "nativist" Buddhist Sinhalese. This fact bodes ill for consociational politics, since this majority segment can, if properly and monolithically organised, dominate the state through democratic means', which is what has happened at times throughout Sri Lanka's history. ${ }^{523}$

\footnotetext{
${ }^{521}$ Kearney, Communalism and language in the politics of Ceylon, pp 140-141

522 De Votta, "Control Democracy, Institutional Decay, and the Quest for Eelam: Explaining Ethnic Conflict in Sri Lanka", p 66

${ }^{523}$ Chehabi, "The Absence of Consociationalism in Sri Lanka", p 56
} 
Perhaps the greatest opportunity lost was the failure to implement the terms of the Bandaranaike-Chelvanayakam Pact in $1957 .{ }^{524}$ In reaction to the language provisions of the Sinhala Only Act many Tamil groups converged on Colombo's esplanade to demonstrate against the government and its policies. A programme of disruptive but non-violent, agitation was promoted by Tamil leaders to emulate Gandhi's satyagraha to convince by extra-parliamentary means the Bandaranaike Government (the first Cabinet since independence not to have a Tamil) to accept the parity of Tamil to Sinhalese in official language policy. Chelvanayakam was at the forefront of this movement, as was his Federal Party that, as its name implies, advocated for Tamil regional units to exist with certain autonomous powers within a federal state. Though the Federal Party did not represent all Tamil opinion they did by their creation demonstrate a new approach to communalism, which gained considerable force and became the leading Tamil political and parliamentary organ until the 1980s.

The Federal Party formed in reaction to Ponnambalam joining the Senanayake Cabinet had key objectives: the creation of a federal union of Ceylon - with two Tamil dominated provinces, along with seven remaining Sinhalese provinces; the curtailment of all state sponsored colonisation by Sinhalese into the Tamil provinces; the promotion of unity among Tamil speakers in Ceylon (not India), meaning Ceylon Tamils, Tamil speaking Muslims and the Indian Tamil plantation workers; and the parity in official status of the Sinhalese and Tamil languages. ${ }^{525}$ To defuse the mounting tension, rioting and vision of violence in the country Bandaranaike and Chelvanayakam met and forged an agreement in July 1957 to placate the political crisis. The crucial tenet of the concord was a measure of devolution and autonomy through regional councils in the majority Tamil Northern and Eastern provinces, allowing the Tamils to federalise without open federalism. These regional councils would have power over certain policy areas like agriculture, development and education. Though not quite achieving parity across the country the Tamil language would have the status of an official language in the above provinces and "reasonable use" in Sinhala-majority areas. ${ }^{526}$

\footnotetext{
${ }^{524}$ For further info on the Pact and the events and politics that surrounded it see Wilson, S.J.V. Chelvanayakam and the Crisis of Sri Lankan Tamil Nationalism, 1947-1977

${ }^{525}$ Wilson, Sri Lankan Tamil Nationalism, p 82

${ }^{526}$ Wickramasinghe, Sri Lanka in the Modern Age, pp 271-272
} 
However, civil servants, jealous of their centralised power, obstructed implementation while certain ubiquitous Buddhist clerics and their laity joined in droves the Opposition U.N.P. who organised marches to protest the Bandaranaike-Chelvanayakam Pact, which they interpreted as an attack against the Sinhala nation and the first steps towards the break-up of the country. Dudley Senanayake dramatically offered to 'sacrifice my life to prevent the implementation' of the Bandaranaike-Chelvanayakam Pact which he and J.R. Jayewardene saw as a template for 'racial division' and an 'act of treachery'. ${ }^{527}$

These reactions ensured the abrogation of the federalising pact in 1958 and contributed towards the massive communal violence that the island had never witnessed before in its modern history. This is what happened on many further occasions, including 1965 when the tables were turned on Dudley Senanayake, when the Opposition, now led by Bandaranaike's widow with Buddhist and Sinhala nationalist support protests annulled any chance of his own pact with the Federal Party being implemented. This demonstrates Ceylon's political paradigm that once in power each of the two main parties will attempt to mitigate communal tension to maintain order and 'yet each will beat the drums of communal nationalism when it is in the opposition', which has almost had the effect of decimating any détente or constitutional accommodation that could have brought a meaningful settlement and only perpetuates instability, distrust and the 'control democracy' due to the real fear of losing the support of the majority community. ${ }^{528}$ The careerist opportunism of senior politicians from both parties was of great detriment to finding lasting solutions to Sri Lanka's problems and displays the path dependent concern that political actors will display 'short term horizons' in aiming for power since though 'they may care about the future' it is 'short-term considerations [that] predominate', meaning in Sri Lanka's case securing the support of the Sinhalese masses. $^{529}$

The loose regional devolution attributed to the Bandaranaike-Chelvanayakam pact, though described by Chelvanayakam as an 'interim adjustment, ${ }^{530}$, was a real and creative response to tranquilise communal tension and maintain a unitary state. Though

\footnotetext{
${ }^{527}$ De Vota, "Control Democracy, Institutional Decay, and the Quest for Eelam: Explaining Ethnic Conflict in Sri Lanka”, p 59

${ }^{528}$ De Vota, "Control Democracy, Institutional Decay, and the Quest for Eelam: Explaining Ethnic Conflict in Sri Lanka", p 59

and Chehabi, "The Absence of Consociationalism in Sri Lanka", p 59

${ }^{529}$ Pierson, "The Limits of Design: Explaining Institutional Origins and Change", p 479

${ }^{530}$ Wilson, Sri Lankan Tamil Nationalism, p 90
} 
not quite federalism, the idea could have served to 'compartmentalise friction' and 'deflect hostility from the central government' by giving community voice within the bounds of state. Yet those who attacked the idea of federalism accusing such proposals as leading to secessionism have only hastened such ideas. As De Votta argues 'the irony is that these forces continue to clamour against the very mechanisms that provide the only viable alternative to maintaining their cherished goal - a united Sri Lanka. ${ }^{, 531}$ The attempt in 1957 was, judging from the hindsight of today's troubles and extremist positions, which could have enabled democratic cohesion and sense of collaboration. As one international South Asian scholar has argued 'the B-C [sic] Pact ... provided for a generous degree of regional autonomy for Tamil areas within the existing framework of the unitary state. It safeguarded the position of the Sinhalese while meeting the needs of the Tamils. Had it been implemented, much of the tragedy that followed in succeeding decades would have been avoided, ${ }^{532}$ Strong statesmanlike leadership was required and Bandaranaike, accused of being a 'Donoughmore Buddhist' ${ }^{533}$, was unable to provide it.

Prime ministerial power had diluted, if not washed away his original ideas of a country of communities through a federal structure by his espousal of exclusionary nationalism and irresolute political management. His Damascene conversion or constitutional amnesia was costly to the country and to himself. De Silva states in scrutiny of Bandaranaike's earlier views on federalism and inter-communalism that it was a 'grim irony that he should be called upon...to articulate the strong opposition of the Sinhalese to any attempt to establish a federal constitution'. ${ }^{53}$ S.W.R.D. Bandaranaike was assassinated by a Buddhist monk in 1959, a conduit of the very nationalistic forces he had done so much to cultivate and represent and yet still could not ultimately gratify - a portentous lesson for all future leaders of Sri Lanka, whether they chose to read it or not. From now on those attempting to reduce communal tension would seem to be swimming against the current of history.

\footnotetext{
${ }^{531}$ De Vota, "Control Democracy, Institutional Decay, and the Quest for Eelam: Explaining Ethnic Conflict in Sri Lanka", pp 68-69

${ }^{532}$ Shastri, "Government Policy and the Ethnic Crisis in Sri Lanka", p 144

${ }^{533}$ Sir John Kotelawala accused Bandaranaike of being a Buddhist for political purposes since he was brought up an Anglican and embraced Buddhism only in his thirties and had to be tutored in Sinhalese on his return from Oxford due to his difficulty with the language - feeling more at home with the Greek classics. He was the only son of Sir Solomon Dias Bandaranaike - an affluent man noted for his fastidious Anglophile ways and as a proud upholder of the elite. For a detailed examination of the prominent Bandaranaike family history see Yasmine Gooneratne, Relative Merits - A Personal Memoir of the Bandaranaike Family of Sri Lanka, London: C. Hurst \& Company, 1986

${ }^{534}$ De Silva, A History of Sri Lanka, p 629
} 


\section{Westminster Beyond the Seas?}

For most New Zealanders the passing of the Statute of Westminster in 1947, well after all the other settler colonies of Britain, did little more than clarify the country's parliamentary sovereignty, rather than usher in heroic independence and end the settlement's colonial legislative immaturity. However, New Zealand's cultural conditions were more complex than they appeared. James Belich, in the second volume of his monumental history of New Zealand entitled Paradise Reforged, argues that New Zealand's record is a unique one based on fundamental links especially with Britain. Belich states that this settler colony engaged in the process of what he cleverly labels 'recolonisation' to become a "Better Britain" and "neo-Britons", a quest which he believes only ended in the 1970s, well after Canada and Australia had gone through similar relationships with Britain. As Belich points out this does not simply mean New Zealand's relationship with Britain was submissive, but more that there were key ideological, economic, cultural and social relationships that pushed this 'periphery' colony to naturally look to the metropolitan Old Country for inspiration and in turn propelled New Zealand into engaging in 'inverse colonialism', which often, and unintentionally, created distinctive and even unintended mutations from the original gene - Britain. ${ }^{535}$ New Zealand's process of British and Westminster constitutional "patriation" would be no different. New Zealand could not and did not provide a perfect clone, despite the hopes of its leaders; instead it was more a deceptive and shadowy South Pacific simulacrum - Westminster Reforged.

J.C. Beaglehole, an earlier New Zealand historian, recognised that despite the country's seemingly clear constitutional progression from colony to nation-state there was still much of interest for the 'historian's microscope'. This captivating social scientist was able to peer through his unique lens and identify the fascinating development of New Zealand national identity through constitutional evolution, which can be viewed by its curious domestic institutional inoculations. New Zealand has often been viewed as the model colony and later the model Westminster however this South Pacific Realm did

\footnotetext{
${ }^{535}$ James Belich, Paradise Reforged - A History of the New Zealanders From the 1880s to the Year 2000, Auckland: Allen Lane, 2001, pp 11-12
} 
not grow meekly or completely with unquestioned Imperial injections and interventions. Without completely rejecting or accepting in Bagehot's terms 'dignified' British and 'efficient' Westminster remedies (both consciously and unconsciously), the New Zealand body politic was quite capable of being immune to such advice and by its constitutional and cultural features stood out from the other daughters of Empire. The main finding of Beaglehole's early analysis was the remarkable result that New Zealand 'managed to act as an independent nation without being independent. It managed to act independently, even - so paradoxical, so subtle, is the growth of British children - while deploring independence'. 536

New Zealand's constitutional and executive traits would be no different. Despite one academic opening his analysis of New Zealand politics from afar that 'New Zealand's history is short and its inhabitants few' ${ }^{537}$ the history of constitutional government went through a gradualist progression similar to that of other settler colonies, while the influence of its citizens consistently belied the sparseness of the population. Premiers and later Prime Ministers from Seddon to Savage were able to impress upon London New Zealand's views well before the advent of formal legal independence in 1947.

Very early in its history was the colony able to claim a 'Constitution'. The first document to claim this exalted status was the New Zealand Constitution Act 1852, which replaced earlier statutory attempts. This Act emanated, naturally, from the United Kingdom and its full title was: 'An Act to grant a Representative Constitution to the Colony of New Zealand'. The provisions of this Act established six provinces (which were abolished in 1875 establishing the country's enduring enchantment with unitary government) and a central parliament named the General Assembly, which consisted of the Governor, an appointed Legislative Council and an elected House of Representatives. With certain Imperial caveats the General Assembly was granted the ability to make laws for the 'peace, order and good government' of the colony. ${ }^{538}$ The Act established parliamentary government, but interestingly it lost the appellation 'Constitution' after only a few years. ${ }^{539}$ Not for the last time would New Zealanders show suspicion at such attempts for such titles entering their political lexicon. Perhaps

\footnotetext{
${ }^{536}$ J. C. Beaglehole, "The Development of New Zealand Nationality", Journal of World History, Vol. II, No. I, 1954, pp 106-107

${ }^{537}$ R. S. Milne, Political Parties in New Zealand, Oxford: Oxford University Press, 1966, p 1

${ }^{538}$ Section 53 of The New Zealand Constitution Act 1852 (Imp)

${ }^{539}$ K. J. Scott, The New Zealand Constitution, Oxford: Oxford University Press, 1962, pp 1-2
} 
this aversion can be answered by Beaglehole, writing in the 1950s, that 'the truth is that New Zealanders had little talent or desire for abstract constitutional thought' ${ }^{540}$

They may not have been inclined to enter the theoretical mêlée of constitutional sophistry, but they were quite adept at the 'efficient' practical application of constitutional abstracts to deal with New Zealand conditions. New Zealand's assumption of Dominion status in 1907 at the instigation of Prime Minister Sir Joseph Ward, brought the country in line with settlements like Canada and Australia but in reality little changed and despite Ward's excitement, the new Dominion quickly forgot its new lofty status as the public, like the politicians 'barely noticed'. 541 Dominion status 'was a change more in nomenclature' than anything else since New Zealand political and constitutional practices, as well as outlook, went on as before. ${ }^{542}$ This was exemplified at the end of World War I when at the Paris Peace Conference New Zealand was admitted in its own right and signed and ratified Versailles as well as entering the League of Nations on its own. Rather than excite the passions of attaining national identity, the senior members of the Reform Government like Sir Francis H. D. Bell and W. Downie Stewart were quick to raise panic at any thought of independence. Prime Minister and Ulsterman William Ferguson Massey assured the members across the House of Representatives that 'I have never liked the arrangement which was made in connection with the League of Nations. There was one dangerous feature in it. I did not agree with everything that has been said, that in signing the Peace Treaty we had become independent nations'. 543

Resistance to other constitutional matters was no different and New Zealand's attitude was unique in the world and the Empire itself since, as Sir Geoffrey Palmer assesses, 'reluctance to take power when it is offered is not often met within constitutional history'. ${ }^{544}$ While the other Dominions manned the bellows, with Britain, which enthused the winds of change for constitutional independence within the Commonwealth they became in Angus Ross's memorable phrase 'gentle zephyrs before

\footnotetext{
${ }^{540}$ Beaglehole, "The Development of New Zealand Nationality", p 115

${ }^{541}$ Gavin McLean, The Governors - New Zealand's Governors and Governors-General, Dunedin: Otago University Press, 2006, p 160

${ }^{542}$ Angus Ross, "Reluctant Dominion or Dutiful Daughter? New Zealand and the Commonwealth in the Inter-War Years", Journal of Commonwealth Political Studies, Vol. 10, No. 1, 1972, p 29

${ }^{543}$ Cited in Ross, "Reluctant Dominion or Dutiful Daughter? New Zealand and the Commonwealth in the Inter-War Years", p 30

${ }^{544}$ Geoffrey Palmer, New Zealand's Constitution in Crisis - Reforming our Political System, Dunedin: John McIndoe, 1992, p 45
} 
they reached New Zealand shores'. ${ }^{545}$ However, it is too easy to chastise the local leaders for their resistance to constitutional and national independence of this defensive Dominion. They in fact were very accurately reflecting the wishes of their voters regardless of party affiliations. Though a 'dutiful daughter dominion' New Zealand's leaders in the early twentieth century 'were at once true interpreters of New Zealand and staunch Imperial statesman' and as such 'their loyalty ... was neither blind nor dumb'. ${ }^{546}$ As one modern scholar has observed, the pre-1935 leaders displayed an instinctive realism which served the country's needs and mood at the time and was certainly the rational choice for New Zealand. ${ }^{547}$

New Zealand's economic and security interests were indelibly linked with Britain and its Empire and New Zealand's leaders protected this relationship. In the constitutional realm New Zealand's Westminster transplantations outwardly were normal for a settler colony, but the country's constitutional practices and powers were not simply a miniature Westminster as will be discussed below. New Zealand as much as she mimicked the 'dignified' parts of the British constitution was constitutionally governed by the 'facts of the local situation, and the conventions built up locally in the past ... dictated events'. The powers of the Houses of Parliament, the Cabinet, the Prime Minister and the Governor and later Governor-General were formed through a process of 'autochthonous evolution' ${ }^{, 54}$, which would solidify as strong executive power emanating from the Prime Minister and his Cabinet. New Zealand, despite seeming to abhor constitutional developments faced in the post war era a vast array of constitutional changes that would formalise and simplify 'efficient' executive dominance centred in the Cabinet room. While culturally New Zealand would look to Britain, its institutional development and practices were from its own soil. Thus New Zealand would have a recolonised constitutional structure with a hybrid of cultural dependence and indigenous institutional self-determination. This would become the actuality, whatever the formal and 'dignified' garb of the constitutional niceties. The juxtaposition of 'dignified' constitutional formality with 'efficient' executive power realities along with the paradox of dependence and independence is neatly illuminated

\footnotetext{
545 Angus Ross, "New Zealand Governors-General In the Inter-War Years" in W. P. Morrell: A Tribute, G. A. Wood and P. S. O’Connor (eds.), Dunedin: University of Otago Press, 1973, p 203

${ }^{546}$ F. L. W. Wood, The New Zealand People at War - Political and External Affairs, Wellington: A. H. \& A. W. Reed, 1971, pp 16-18

${ }^{547}$ See David J. McCraw, "The Zenith of Realism in New Zealand's Foreign Policy", Australian Journal of Politics and History, Vol. 48, No. 3, 2002, pp 353-368

${ }^{548}$ D. K. Fieldhouse, "Autochthonous Elements in the Evolution of Dominion Status: The Case of New Zealand”, Journal of Commonwealth Political Studies, Volume 1, 1962, pp 108-109
} 
with the issues generated by the adoption of the independence enacting Statute of Westminster in 1947, which ended New Zealand's parliamentary infantilism.

\section{The Statute of Westminster - To be or not to be Independent?}

Not all constitutional developments within the Empire can be characterised as young cubs of settler colonies prizing concessions from a weary British lion. In fact as John Darwin has stated 'Dominionhood was not the most that the Dominions could extract from the grudging Imperial centre: it was the most that the internal politics of the Dominions themselves would permit'. ${ }^{549}$ The Statute of Westminster was meant to be something important. The Statute of Westminster 1931 was not in itself a remarkable piece of legislation, but it did for the Dominions have symbolic value of legitimising their legislative sovereignty, which, basically, in practice had been exercised anyway. Emanating with wistful impact the former Prime Minister Arthur Balfour now returned as an Earl and Lord President, and with his aristocratic nonchalance composed a declaration for the Imperial Conference 1926 which at essence provided for the Dominions and the United Kingdom to be:

autonomous communities within the British Empire, equal in status, in no way subordinate one to another in any aspect of their domestic or external affairs, though united by a common allegiance to the Crown, and freely associated as members of the British Commonwealth of Nations. ${ }^{550}$

The Statute recognised the equality of the Dominions and established legally their independent powers without hindrance and also, crucially in the cultural sense, at the same time maintained the 'dignified' Crown as the common constitutional denominator. It was promulgated to erase any doubts over their legal powers and addressed the demands of the campaigning Dominions Canada, Ireland and South Africa. The Irish, predictably, welcomed the new legislation. As P. McGilligan told the Dáil with colourful candour in July 1931, the Statute of Westminster's adoption meant that 'the [British] King acting on the advice of the British Government can no more contract for the Irish Free state than can the King of Italy or the Mikado of Japan'. For the Irish the

\footnotetext{
${ }^{549}$ John Darwin, "A Third British Empire? The Dominion Idea in Imperial Politics" in The Oxford History of the British Empire: Volume IV - The Twentieth Century, Judith M. Brown and Wm. Roger Louis (eds.), Oxford: Oxford University Press, 2001, p 71

${ }^{550}$ Report of the Inter-Imperial Relations Committee, Imperial Conference, 1926 in Speeches and Documents on the British Dominions 1918-1931 - From Self-Government to National Sovereignty, Arthur Berriedale Keith (ed.) London: Oxford University Press, 1938, p 161
} 
fundamental rationale was 'that there must be uprooted from the whole system of this State the British government' and though the British King would remain, he 'is a King who functions entirely, so far as Irish affairs are concerned, at the will of the Irish Government'. The Statute of Westminster was pushed and passed since Ireland 'had to get completely rid of any power, either actual or feared, that the British Government had in relation to this country'. ${ }^{551}$ In contrast George Forbes told Britain and the Dominions words that any New Zealand Prime Minister would have echoed until the 1970s on the country's attitude towards constitutional change:

New Zealand has not, in any great measure, been concerned with the recent development in the constitutional relations between the members of the British commonwealth of Nations. We have felt that at all times within recent years we have had ample scope for our national aspirations and ample freedom to carry out in their entirety such measures as have seemed to us desirable. We have valued and still value our close connexion with the United Kingdom and with our sister Dominions and we should have been well content to allow constitutional relationships to settle themselves in the time honoured way, in accordance with the necessities of the position and the requirements of the time. $^{552}$

The New Zealand attitude towards the Statute and constitutional development was at one extreme while Ireland was another - both were, by the flexibility and fluidity of Westminster words, correct despite their contrary interpretations.

The authoritative scholar on the Statute of Westminster generously described New Zealand's reception as 'lukewarm'. ${ }^{55}$ In fact New Zealand did not see any need for this 'poisonous document' ${ }^{554}$ as Prime Minister Gordon Coates described it, while Sir Francis H. D. Bell, his predecessor and the first New Zealand-born Prime Minister referred to that 'damned Statute of Westminster propaganda' ${ }^{555}$, which both believed

\footnotetext{
${ }^{551}$ Speech by P. McGilligan, Dáil Eireann, July 16, 1931 in Speeches and Documents on the British Dominions 1918-1931 - From Self-Government to National Sovereignty, pp 240-242

${ }^{552}$ George Forbes' introductory speech at the Imperial Conference, October 11930 in Speeches and Documents on the British Dominions 1918-1931, p 209

${ }^{553}$ Wheare, The Statute of Westminster and Dominion Status, p 227

${ }^{554}$ W. David McIntyre, Dominion of New Zealand: Statesmen and Status 1907-1945, Wellington: New Zealand Institute of International Affairs, 2007, p 122

${ }^{555}$ W. Downie Stewart, The Right Honourable Sir Francis H. D. Bell, P.C., G.C.M.G., K.C., His Life and Times, Wellington: Butterworth \& Co., 1937, p 262
} 
would lessen the bonds of Empire that upheld their country's defence, financial and cultural needs. Significantly, for the Statute of Westminster to become law it needed to be adopted and ratified by the local Dominion parliament rather than imposed by Downing Street diktat. This condition was largely a New Zealand initiative with the help of the other recalcitrant Dominions of Australia and Newfoundland to deny application of the Statute until their local Parliaments assented, which was explicitly stated in the Statute itself. ${ }^{556}$ New Zealand's reactions were predictable in light of their previous aversion to constitutional change despite the other Dominions adopting the Statute almost immediately. Even Australia relented in 1942 faced with British reversals in the War, the Japanese spectre and Curtin's Labor Government, and unlike their neighbour across the Tasman they already had a firm written constitutional structure with detailed federal and centre provisions. ${ }^{557}$

In 1935 New Zealand elected their first Labour Government under Michael Joseph Savage, which has been rightly viewed as one of the most influential and radical Governments in New Zealand history. ${ }^{558}$ New Zealand's new Government made up of trade unionists of varying socialist hues promised change from the conservative rural farmer dominated regimes of the recent past. Domestic transformation was immediately evident and even in the Imperial preserve of foreign policy did New Zealand dare to challenge the Conservative Baldwin-Chamberlain Governments. The Savage Ministry was ideologically part of the left with the appropriate international socialist vision of world order and justice. The Labour Government did not hesitate to have different opinions with the Conservative Government in London. On crises like the Italian and German intervention in Spain, Japanese aggression in Manchuria and especially the appeasement of the Hoare-Laval deal in response to the Italian invasion of Abyssinia, the Labour Government informed London that it could not support such proposals. At the League of Nations, New Zealand's representative William Jordan and at the

\footnotetext{
${ }^{556}$ See sections 8 and 10 especially of the Statute of Westminster 1931; Ross, "Reluctant Dominion or Dutiful Daughter? New Zealand and the Commonwealth in the Inter-War Years", p 34 and Leslie Zines, Constitutional Change in the Commonwealth, Cambridge: Cambridge University Press, 1991, p 7

${ }^{557}$ Stuart Macintyre, A Concise History of Australia, $2^{\text {nd }}$ edition, Cambridge: Cambridge University Press, 2004, p 192

${ }^{558}$ See for example Barry Gustafson, From the Cradle to the Grave - A Biography of Michael Joseph Savage, Auckland: Reed Methuen, 1986
} 
Imperial Conferences, Savage and Walter Nash voiced an almost unrepentant view against the appeasement of the time. ${ }^{559}$

However, despite such independence, Labour was not rejecting the Empire and Commonwealth and there was no thought that Labour would not support Britain in the event of war. ${ }^{560}$ When war did emerge Savage himself pronounced a position and initiative, without any legal or diplomatic pressure from Britain, which all his predecessors would have supported. Savage professed that the cultural obligation and determination would be clearly understood in New Zealand more than elsewhere since -

for almost a century, behind the sure shield of Britain, we have enjoyed and cherished freedom and self-government. Both with gratitude for the past, and with confidence in the future, we range ourselves without fear beside Britain. Where she goes, we go, where she stands, we stand. We are only a young nation, but we are one and all a band of brothers, and we march forward with a union of hearts and wills to a common destiny. ${ }^{561}$

However, in spite of such stirring and sincere words from Labour, which were supported by the conservative National Party ${ }^{562}$, there would be no great impetus towards constitutional initiative - quite the opposite. Constitutional development was viewed across the political spectrum as disloyalty to Britain, not as a necessarily rational or natural step. Many would have echoed Sidney Holland who was proud to be 'a Britisher through and through' and culturally viewed anything remotely anti-British as disloyal and wrong. ${ }^{563}$ As one legal scholar has noted of New Zealand: 'legal issues

\footnotetext{
${ }^{559}$ Malcolm McKinnon, Independence and Foreign Policy - New Zealand in the World since 1935, Auckland University Press, 1993, p 15-17 and Malcolm Templeton, "Beginnings" in An Eye an Ear and a Voice, Malcolm Templeton (ed.), Wellington: Ministry of Foreign Affairs and Trade, 1993, p 5-6

${ }^{560}$ Sir Alister McIntosh, "The Origins of the Department of External Affairs", Sir Alister McIntosh (ed.), New Zealand in World Affairs Volume I 1945-1957, Price Milburn, Wellington, 1977, pp 14-17

${ }^{561}$ Extracts from a broadcast by the Prime Minister, the Right Hon. M. J. Savage, 5 September 1939 in Documents and Speeches on British Commonwealth Affairs 1931-1952, Vol. I, p 491.

${ }^{562}$ Interestingly Sidney Holland as Prime Minister echoed Savage's speech when discussing the Suez Crisis in 1956. Holland told the House that 'It was a very great man who coined the sentence, "Where Britain Stands, we stand". I have said many times that we on this side of the House adopt that. I believe that that is the mood of the people of New Zealand. Where Britain stands, we stand; where she goes we go, in good times and bad'. Statement by the Right Honourable S. G. Holland in the House of Representatives, 7 August 1956 in New Zealand Foreign Policy - Statements and Documents 1943-1957, Wellington: Government Printer, 1972, pp 434-435

${ }^{563}$ Barry Gustafson, The First 50 Years - A History of the National Party, Auckland: Reed Methuen, $1986, \mathrm{p} 41$
} 
relating to sovereignty were dealt with at a more figurative, even emotional, level' ${ }^{564}$ The difference was that unlike India, but like the elite in Ceylon, the emotion was directed at promoting the relationship with Britain, not hiding or ridding it. The situation was as Beaglehole recounted before 1947, continuing the favoured family metaphor that:

New Zealand got responsible government, got control of its natives, got control (very largely) of its governor, became a titular Dominion, was dragged into Dominion status, stood by and saw the Statute of Westminster passed. But, once it had got essential control of its own internal affairs, it was not really interested in constitutional evolution; or rather its interest was that of a rigid disapproval. It is a "Dominion" in spite of itself. It has not pursued, with passionate experimentation, the idea of equal nationhood; in the Imperial family it is the daughter-nation that preferred not to smoke and drink with its emancipated sisters, that shuddered a little and drew its garments somewhat closer when Canada and South Africa began to saunter on the boulevards of the world ... New Zealand, in fact, psychologically has remained a colony... ${ }^{565}$

This reluctance to "saunter on the boulevards" of constitutional progress was evidenced in New Zealand that despite having elected one of the most transformative governments in its history and even in the Commonwealth, it was only with miserly unwillingness that acceptance of the Statute of Westminster occurred and even then a whole twelve years after Labour came to power. Labour preferred to dress the Statute in traditional loyalist dress long out of fashion in most of the Commonwealth instead of procuring the latest independent haute couture from say India's cutting edge constitutional designers. New Zealand was the very last of the Dominions to pass the Statute of Westminster, sixteen years after it was available. In an era where even the importation and sale of Lone Ranger comics was banned as a bad influence on the public ${ }^{566}$ it is difficult to imagine the conscious effort in New Zealand to import in vogue constitutional creations from afar. Ironically New Zealand became "independent" the same year as India, though it 'had not quite reached the Rubicon of nationhood that India had just months

\footnotetext{
${ }^{564}$ Peter C. Oliver, The Constitution of Independence - The Development of Constitutional Theory in Australia, Canada, and New Zealand, Oxford: Oxford University Press, 2005, p 191

565 (J.C. Beaglehole) "New Zealand in the Commonwealth: An Attempt at Objectivity" in New Zealand Institute of International Affairs, Contemporary New Zealand - A Survey of Domestic and Foreign Policy, Wellington: New Zealand Institute of International Affairs, 1938, pp 2-3

${ }^{566}$ Belich, Paradise Reforged - A History of the New Zealanders From the 1880s to the Year 2000, p 318
} 
earlier' ${ }^{567}$ New Zealand's constitutional culture towards Britain was in contrast to India's.

On 23 February 1944 Sir Cyril Newall, the Governor-General, gave the Speech from the Throne and informed the New Zealand Houses of Parliament that his Ministers proposed

to place before Parliament the question of the adoption of the Statute of Westminster, the enactment of which would bring New Zealand in line with the other self-governing Dominions. The adoption of this measure will remove doubts in the eyes of foreign powers regarding the Sovereign status of New Zealand, and will at the same time have the practical effect of removing existing legal drafting and administrative difficulties both in New Zealand and in the United Kingdom. ${ }^{568}$

This wording and legislative statement of the Labour Government's was not only far from a proclamation of independence it was also with heavy anxiety and dislike at the highest political level that it even made it in the Governor-General's speech. The Head of the Prime Minister's Department and of External Affairs, Alister McIntosh, confided at the time to senior civil servant and then New Zealand High Commissioner to Canberra, Carl Berendsen: 'We are in a great fuss here over the adoption of the Statute of Westminster ... The Prime Minister [Peter Fraser] immediately got cold feet and wanted to cut all reference to the adoption of the Statute from the Governor-General's speech. We managed to hold him in, on the understanding that he would not be expected to bring down any legislation until after he had been to the United Kingdom and discussed the question of consequential constitutional amendments with the British Law Officers'. 569

Fraser probably only acquiesced to the Speech and the Statute because doubts were being raised during wartime as to New Zealand's international status. As civil servants were concerned that

\footnotetext{
${ }^{567}$ Kumarasingham, “The 'New Commonwealth' 1947-49: A New Zealand Perspective on India Joining the Commonwealth", pp 444-445 and 452

${ }^{568}$ New Zealand Parliamentary Debates (henceforth NZPD), Vol. 264, p 7, February 23, 1944

${ }^{569}$ Sir Alister McIntosh to Sir Carl Berendsen, 25 February 1944 in Undiplomatic Dialogue - Letters Between Carl Berendsen \& Alister McIntosh 1943-1952, Ian McGibbon (ed.), Auckland: Auckland University Press, 1993, p 68
} 
so long as New Zealand continues to delay the adoption of the Statute, the nonexpert in other countries will tend to be doubtful of our international status as compared, for example to Australia and Canada. In October, 1943, for instance, in a United States Senate debate on participation in post-war organisation, Senator Gillette objected to the use of the words "free and sovereign" nations to define those countries with which the United States could join in the establishment and maintenance of international authority on the grounds that they might exclude the Dominions. New Zealand was specifically mentioned as a country with limitations. ${ }^{570}$

However this embarrassment was largely confined to the senior colleagues in Wellington. As was written at the time of the Governor-General's speech the country's diffidence to the empowering Statute, which 'was not altogether surprising; for the time lag was great, the terms of the Statute, even if one remembers them, are not in themselves remarkably enlightening, and important as any act of parliament, it precise significance has a habit of evading recollection. Nor, we must admit, was this particular statute very highly esteemed in New Zealand when it was first enacted'. With the above in mind it is perhaps unsurprising that further delay occurred and New Zealand's 'legislative inability' continued till $1947 .^{571}$ Once again combined with an aversion for constitutional change, the alarm of appearing disloyal, which potentially could jeopardising economic and defence interests, was a significant cultural factor in ossifying resistance.

The Scottish-born former trade unionist, Peter Fraser, told the House as Prime Minister that New Zealand did not want to pass the legislation during wartime since "Lord Hawhaw", the Germans and the 'Japs' might use New Zealand's adoption as 'propaganda' to herald the end of Britain's influence since it could be used to suggest the unthinkable 'severance from the Old Country'. New Zealand and its government thought this despite Britain never suggesting such a hypothesis, and even the Conservative Lord

\footnotetext{
570 "Summary of Reasons for which New Zealand should adopt the Statute of Westminster", 7 November 1947, Statute of Westminster 1927-1947, EA 1 159/1/5 Part 4 IA 1 123/6, Archives New Zealand/Te Whare Tohu Tuhituhinga O Aotearoa, Head Office, Wellington (henceforth ANZ)

${ }^{571}$ Writers like Crown Solicitor A. E. Currie and Professor R. O. McGechan wrote advocating the step to clear doubt on our legislative abilities. A. E. Currie, New Zealand and the Statute of Westminster 1931, Wellington: Butterworth \& Co., 1944 and R. O. McGechan, "Status and Legislative Inability" in J.C. Beaglehole (ed.), New Zealand \& the Statute of Westminster, Wellington: Whitcombe \& Tombs, 1944, p
} vii 
Cranborne, Secretary of State for Dominion Affairs, 'did not ... think there was much in it' when he was consulted on the matter at New Zealand's initiative. ${ }^{572}$ Fraser did want to allow 'ill-founded accusations that Labour was anti-British' to gain credence by passing the Statute during wartime ${ }^{573}$ despite eminent New Zealand academics correctly observing at the time that ratification would not have any harmful effect with Britain. ${ }^{574}$

Indeed, 'despite having social and political credentials that might seem to question the long-established tenets of New Zealand traditions, the New Zealand Labour Party was just as strong as the conservative and traditionalist pro-Britain National Party as upholders of the Commonwealth. Labour was more progressively Commonwealth, while National held to the older virtues of Empire and Imperial dependence' ${ }^{575}$ Fraser especially realised the importance of the Commonwealth and its centrality to New Zealand self-interests. Labour was culturally just as royalist as the National Party and firmly believed in the 'dignified' apparatus of being a loyal British Westminster. The New Zealand Labour Party's version of independence was one that was 'moderated by a fundamental commitment to the Commonwealth' and in these years and for many beyond 'both National and Labour in New Zealand stood for alignment with Britain on the great issues of the day, ${ }^{576}$ Fraser and New Zealand's attitude towards independence can be perceived from his speech to an international audience at the San Francisco Conference in June 1945:

To us of the British Commonwealth it is very difficult to distinguish between self-government and independence, for to the self-governing sovereign States of the British Commonwealth, self-government is independence and independence is self-government ... We British peoples have learnt that, as well as being independent, we are interdependent, and that the future of the British Commonwealth depends upon our interdependence and co-operation. ${ }^{577}$

\footnotetext{
${ }^{572}$ NZPD, Vol. 279, p 534, 7 November 1947

${ }^{573}$ Michael Bassett and Michael King, Tomorrow Comes the Song - A Life of Peter Fraser, Auckland: Penguin, 2000, p 325

${ }^{574}$ See Beaglehole (ed.), New Zealand \& the Statute of Westminster

${ }^{575}$ Kumarasingham, “The 'New Commonwealth' 1947-49: A New Zealand Perspective on India Joining the Commonwealth", p 446

${ }^{576}$ McKinnon, Independence and Foreign Policy - New Zealand in the World since 1935, p 62 and p 81

${ }^{577}$ Statement by the Right Honourable Peter Fraser, Chairman of the Trusteeship Committee of the San Francisco Conference, June 1945 in New Zealand Foreign Policy - Statements and Documents 19431957, p 93
} 
In August 1947, just days before India gained independence, Sidney Holland, Leader of the Opposition, was discussing his private member's bill to abolish the Legislative Council (which will be discussed in detail in a following chapter) the Prime Minister, who agreed with the National Party leader on abolition, provided in answer a largely unforeseen disclosure of constitutional significance. The Evening Post reported that 'a surprise development occurred in the House of Representatives last night when, during the second reading on the Legislative Council Abolition Bill, the Prime Minister (Mr Fraser) introduced an amendment proposing that prior to any change being made in the Constitution of the Legislature, the Statute of Westminster be extended to the Dominion..., ${ }^{578}$ To clean up its legislative home, New Zealand wanted to get rid of the upper chamber, but since she did not formally have the ability to do so herself asked Britain to help with the renovations by passing at New Zealand's request the New Zealand Constitution Amendment Act. While Britain passed the laws, New Zealand adopted the Statute of Westminster and officials in Wellington believed this 'will will completely remove these doubts and establish fully the competence of the New Zealand Parliament to deal with its own Constitution' and end its colonial image. ${ }^{579}$

Civil servants and Government members clearly wanted to make it clear that the adoption of the Statute was merely for legalistic reasons to provide legislative competence to make constitutional amendments and erase doubts internationally rather than an Act to break constitutional and cultural ties with the United Kingdom. A paper from the Prime Minister's desk assured its readers:

New Zealand has for long taken an independent and fully sovereign part in British Commonwealth and in international affairs. At the same time we have maintained our intimate association with the United Kingdom and with the other members of the Commonwealth. Not only the day-to-day actions of the Government and the attitude of New Zealanders to the two Great Wars, but also the actions of private individuals and groups, show that this recognition of independence and inter-dependence is part of our national way of thinking and feeling. No definitions or statutes can affect this practical position: they cannot take away New Zealand's independent status, nor can they reduce our desire to remain associated with our friends and kinsmen. It is, however, a frequent

\footnotetext{
${ }^{578}$ Evening Post, 7 August 1947

${ }^{579}$ A. McIntosh to all NZ Missions overseas re: Statute of Westminster, 19 September 1947, Statute of Westminster 1927-1947, EA 1 159/1/5 Part 4 IA 1 123/6, ANZ
} 
occurrence - especially in countries which share the British legal tradition - that contemporary legal forms lag behind the actual facts. Often this does not matter; but from time to time it is necessary to bring the law up-to-date - not to alter the contemporary state of affairs, but merely to ensure that the law more accurately describes it. ${ }^{580}$

Fraser assured both sides of the House of Representatives that he would not engage in any legislation that 'would do anything to lessen the ties' and believed instead that the Statute 'will strengthen the ties between the various parts of the Commonwealth and ourselves in New Zealand and the Mother-country'. ${ }^{581}$ However, not all were becalmed by the Prime Minister's hopes. Frederick Doidge, National MP for Tauranga, and later External Affairs Minister and later still High Commissioner to London, thought the Statute represented 'a legal bill of divorcement'. Doidge spoke for certain MPs when he argued against passing the Statute of Westminster by citing Ireland's remarkable behaviour being attributable to having passed the Statute, which he continued could only encourage Pakistan and India to leave and even imaginatively argued that the economic crisis in Britain made it inopportune to request the legislation. For this former employee of the Beaverbrook press, New Zealand's 'loyalty to the Motherland is an instinct as deep as religion' and postulated to his fellow parliamentarians that there 'are a few "crackpots" who want to see the liquidation of the British Empire and who welcome this legislation because it will help that way'. 582

Other indicative opinion emerged, including that of Dr Martyn Finlay, Labour Member for North Shore, and future Attorney-General and Minister of Justice in the third Labour Government, who spoke in favour of the Bill and endeared himself to the House by stating that 'we love the British because the British love us. That spirit transcends all written documents', while former law professor and future Education Minister and Speaker Ronald Algie, National Member for Remuera, though in favour of the Statute of Westminster, was concerned that it would encourage Russia to claim separate representation for the Soviet States and thus increase communism's international

\footnotetext{
580 "Notes on the purpose and effect of the adoption by New Zealand Parliament of Sections 2,3,4,5 and 6 of the Statute of Westminster and the New Zealand Constitutional Amendment (Consent and Request) Bill. Circulated by the Prime Minister and Minister of External Affairs, Rt. Hon. Peter Fraser, 7 November 1947, Statute of Westminster 1927-1947, EA 1 159/1/5 Part 4 IA 1 123/6, ANZ ${ }^{581}$ NZPD, Vol. 279, 7 November 1947, p 534

${ }^{582}$ NZPD, Vol. 279, 7 November 1947, pp 535-538 and see notes on Doidge, Statute of Westminster 1927-1947, EA 1 159/1/5 Part 4 IA 1 123/6, ANZ
} 
clout. $^{583}$ With the benefit of hindsight one cannot help but agree with noted legal scholar J. F. Northey that the debates over the Statute of Westminster "contain so much evidence of a gross misconception of the purpose and effect of the Statute' ${ }^{584}$ The Opposition, though containing distress from speakers like Doidge did not oppose the passing of the Bill especially since, it was argued, it was necessary to give the New Zealand Parliament competence to pass National's proposal to abolish the Legislative Council. ${ }^{585}$ New Zealand's reaction was culturally, however, an autochthonous one as will be seen later in chapter ten.

All these responses evinced from leading New Zealanders demonstrated at the political level an emotive reaction towards constitutional change. Unlike India these passions were directed at maintaining the status quo culturally and for some constitutionally. Fraser and his official and political supporters strained every nerve to couch the constitutional change as one that merely brought the country in line with the other Dominions and that it only eradicated doubt as to the ability to amend the constitution and New Zealand's international status - rather than a move that signified independence from Britain. Symbolically in the year the legislation was passed, instead of breaking with Britain the New Zealand Cabinet agreed to Attlee's plea for help during its financial crisis and sold its primary produce to Britain below world rates and even continued rationing to maximise exports to "Home" which in 1947 still received more than seventy-six per cent of New Zealand's exports. ${ }^{586}$ As one member of the Legislative Council exclaimed when the legislation finally passed - 'this day will not be in future celebrated as the $4^{\text {th }}$ July is celebrated by the first of the family which broke away. 587

And yet in modern times many consider that New Zealand had in fact formalised its independence when the Statute of Westminster received the Royal Assent from Sir Bernard Freyberg, their war hero and Governor-General on 25 November 1947. Dr Michael Cullen, like Fraser, Deputy Prime Minister and Deputy Leader of the Labour

\footnotetext{
${ }^{583}$ NZPD, Vol. 279, 11 November 1947, pp 550 and 554

${ }^{584}$ J. F. Northey, "The New Zealand Constitution” in J. F. Northey, The A. G. Davis Essays in Law, London: Butterworths, 1965, p 156

${ }^{585}$ W. D. McIntyre, "Peter Fraser's Commonwealth: New Zealand and the Origins of the New Commonwealth in the 1940s" in New Zealand in World Affairs Volume I 1945-1957, pp 66-68

${ }^{586}$ Keith Sinclair, Walter Nash, Auckland: Auckland University Press/Oxford University Press, 1976, pp

272-273 (Nash was Minister of Finance at the time); Bassett and King, Tomorrow Comes the Song -A

Life of Peter Fraser p 322 and Edmund Dell, The Chancellors - A History of the Chancellors of the Exchequer 1945-90, London: Harper Collins, 1996, p 40

${ }^{587}$ NZPD, Vol. 279, 21 November 1947, p 86
} 
Party, told the House on the $150^{\text {th }}$ Anniversary of the House of Representatives first sitting in 2004 that New Zealand became sovereign and independent with the adoption of the Statute of Westminster. ${ }^{588}$ Michael King, a popular historian, stated the same in his widely read history of the country ${ }^{589}$ while leading current affairs publication, the Listener, very recently even advocated that 25 November should become a national holiday as it was the day 'we gained full independence by ratifying the Statute of Westminster in 1947,590

However, in the 1940s New Zealand did not see the Statute of Westminster as something which 'cut any Gordian knots' because 'knots there may be, but they can, it seems, be untied as they have been so far untied, by political manipulation that is independent of strictly legal status within the Commonwealth itself'. ${ }^{591}$ As Berenson expostulated 'we had all the self-government we wanted ... We didn't see the need for any Statute of Westminster. We were doing all right without it' ${ }^{592}$ New Zealand had always carried out its own constitutional wishes even if that meant going against the Sovereign's Representative who also represented England culturally and constitutionally ${ }^{593}$ or doing what they liked domestically on electoral and institutional matters such as the abolition of the provinces and the "country quota" (these issues will be discussed in the next chapter). However, they did accept a Commonwealth recommendation in 1948 on nationality and citizenship, which the other Realms had urged, which now allowed New Zealand to issue its own passports and grant its own citizenship status for the first time. Though many New Zealanders, including their parliamentary representatives, preferred to state themselves "British" over "New Zealander" for many years afterwards. ${ }^{594}$ Culturally and sentimentally, however, His (and later Her) Majesty's Government in New Zealand was always careful to avoid conspicuous change to their 'dignified' relationship with Britain. As Sir Cecil Day from London's Cabinet Office, who had worked at Government House, Wellington as a junior official from Britain, told Sir Alister McIntosh privately -

\footnotetext{
${ }^{588}$ NZPD, 150th Anniversary Sitting of Parliament, 24 May 2004 p 13192

${ }^{589}$ Michael King, The Penguin History of New Zealand, Auckland: Penguin Books, 2003, p 420

${ }^{590}$ Tim Watkins, "Get it in Writing", New Zealand Listener, Vol. 204, No. 3456, August 5-11, 2006

${ }^{591}$ Beaglehole, "Preface" in Beaglehole (ed.), New Zealand \& the Statute of Westminster, p xiii

${ }^{592}$ Cited in Ross, "Reluctant Dominion or Dutiful Daughter? New Zealand and the Commonwealth in the Inter-War Years", p 43

${ }^{593}$ Unlike other Dominions which had long since stopped the practice in New Zealand the GovernorGeneral was not only the King's Representative but representative of Britain as well till 1939, when the first British High Commissioner arrived, but continued the sole channel of communication between the two Governments till 1941.

${ }^{594}$ Bassett and King, Tomorrow Comes the Song - A Life of Peter Fraser, p 325 and Belich, Paradise Reforged - A History of the New Zealanders From the 1880s to the Year 2000, pp 318-320
} 
In my time, New Zealand Governments avoided action in the belief that public opinion would interpret the step as weakening the links with the Old Country and so would be opposed to it. Actually I imagine, few ordinary citizens in New Zealand knew at that time what full adoption of the Statute involved. Some who did thought it would be absurd for the little country to parade its independence in this way. Up to the middle of 1935 when I left, New Zealand hadn't got used to "Equality of Status". It was only later that the idea lost its strangeness, following upon the many New Zealand ventures in the field of independent international action. Sentiment excepted, there does not seems to me to have been at any time since the Statute of Westminster was passed, any particular reason for avoiding its adoption. ${ }^{595}$

Most New Zealanders, if they troubled themselves over the intricacies and vagaries of the Westminster system, would have agreed with the T. Clifton Webb, National Member for Rodney, (who like Doidge would later become K.C.M.G., Foreign Minister and High Commissioner to London) when he stated with a degree of weary resignation to accept the symbolic burden which the Statute of Westminster placed. Since Britain had no objection he had 'decided, not with any great enthusiasm - I have no emotional enthusiasm for it, but I have less emotional opposition to it - I repeat that I have decided, after weighing up the pros and cons as I have done, to give my support to the Bill'. ${ }^{596}$ Fraser received, no doubt with pleasure, a personal telegram from his old friend Bill Jordan who informed his master that he had 'attended House of Lords today on passing through all stages of the New Zealand Constitution (amendment) Bill. Your remark that if passing of an Act would weaken the ties between New Zealand and other parts of the Empire you would have nothing to do with it, was heartily applauded. Lords Addison, Salisbury, Samuel and Simon all spoke in support of the Bill and expressed admiration for what has been done by the people of our Dominion'.597 Interestingly of the grandees that 'heartily applauded', Viscount Simon ${ }^{598}$ exclaimed

\footnotetext{
${ }^{595}$ Sir Cecil Day, Cabinet Offices, London to McIntosh, 7 October 1947, Statute of Westminster $1927-$ 1947, EA 1 159/1/5 Part 4 IA 1 123/6, ANZ

${ }^{596}$ NZPD, Vol. 279, 7 November 1947, p 545

${ }^{597}$ Personal Telegram from High Commissioner for New Zealand in London (Sir William Jordan) to Fraser, 2 December 1947, Statute of Westminster 1927-1947, EA 1 159/1/5 Part 4 IA 1 123/6, ANZ

${ }^{598}$ Viscount Simon was a significant player in British politics having held many high offices in various administrations including Home Secretary, Foreign Secretary, Chancellor of the Exchequer and Lord Chancellor. As Sir John Simon he presided over an ineffective Commission in 1927 to study
} 
with kindly puzzlement that 'It is most remarkable that ever since 1857 , ninety years ago, such has been the contentment with which New Zealand has lived under its existing Constitution that it has never even asked this Parliament to alter it' ${ }^{599}$

As Beaglehole vainly reminded New Zealanders: 'We do well to be vigilant about our constitutional rights and our constitutional duties, but this is not to presuppose that the constitution is some silk-wrapped mystery, laid in an Ark of the Covenant round which alone the sleepless priests of the Crown Law Office tread with superstitious awe'. ${ }^{600}$ The reality was that since well before 1947 New Zealand could and did actually do what they wanted especially by simplifying the constitutional structure without lengthy deliberation. In fact, as shall be shown, New Zealand Prime Ministers and Cabinets with their unquestionable primacy over all others in the New Zealand political system were quite prepared to privately play by their own rules and established their own culture of operating British Westminster institutions, often contrary to the conventions and norms they ostensibly admired at the Palaces of Westminster and Buckingham.

constitutional reform in India, which carried his name and included future Prime Minister Clement Attlee who later proved more effective with India.

${ }^{599}$ Parliamentary Debates, Hansard, House of Lords, Official Report, Vol. 152, No. 16, Tuesday, 2 December 1947 (which accompanied Jordan's telegram to Fraser)

${ }^{600}$ Beaglehole, "The Statute and Constitutional Change" in Beaglehole (ed.), New Zealand \& the Statute of Westminster, p 50 


\section{The Executive Purity of the "Wellington Model"}

New Zealand political scientists are very fond of quoting Arend Lijphart's assessment that the country was the "purest example'601 or even the 'perfect example of the Westminster model' ${ }^{602}$ The crucial aspect from his analysis to this study is the concentration of executive power resident in the New Zealand system. However, when compared to other Westminsters, New Zealand stands out for many reasons. Most of the New Westminsters of this era have either federalism or some regional government such as Canada, Australia, India and South Africa; and all of these countries have written constitutions, in many cases with rigid and entrenched provisions, as well as upper houses. Though the executives of these countries, as expected in Westminster systems, have considerable power, New Zealand's central executive alone was unfettered by federalism, bicameralism or a single formally printed document establishing its powers which gave the New Zealand executive 'unbridled power'. ${ }^{603}$ Sir John Marshall, a former Prime Minister and one of the country's longest serving cabinet ministers mentions at the start of a book on the reform of parliament that unlike most countries, New Westminsters included, constitutional documents and even those governing elections such as the Electoral Act 1956 (which he framed as Minister of Justice) can be changed by revealing the myth of entrenchment in New Zealand:

our constitutional laws are contained in ordinary statutes capable of being amended or repealed by a majority vote in Parliament. It is therefore not legislatively difficult for a Government to make constitutional changes. Even the entrenched sections of the Electoral Act covering the length of the parliamentary term, the age and method of voting, the membership of the Representation Commission, the number of electorates and the tolerance in the

\footnotetext{
${ }^{601}$ Arend Lijphart, "The Demise of the Last Westminster System? Comments on the Report of New Zealand's Royal Commission on the Electoral System", Electoral Studies, Vol. 6, No. 2, August 1987, pp 97-105

${ }^{602}$ Arend Lijphart, Democracies - Patterns of Majoritarian and Consensus Government in Twenty-One Countries, New Haven: Yale University Press, 1984, pp 16-20

Note: His comments were made before New Zealand's radical change of electoral system in 1993.

${ }^{603}$ The phrase is famously from Geoffrey Palmer, Unbridled Power - An Interpretation of New Zealand's Constitution and Government, $2^{\text {nd }}$ edition, Auckland: Oxford University Press, 1987. With the transition to the Mixed Member Proportional electoral system in 1993 the title conspicuously changed in subsequent editions to Bridled Power - New Zealand's Constitution and Government
} 
size of electorates can always be amended or repealed by first repealing the entrenching section which is not itself entrenched. ${ }^{604}$

In Leslie Zines's estimation, in comparison to other settler Commonwealth nations this small country was an 'executive paradise' since

New Zealand stands out as having the simplest constitutional framework - no federal system, no entrenched restrictions on power, no Upper House, and a system of responsible government that generally ensures ultimate control by the Executive of the Legislature. There is, therefore, nothing in the way of constitutional checks and balances... ${ }^{605}$

So to redefine Lijphart's appraisal, New Zealand had the "purest" executive of the Westminsters in the sense that the power of the Prime Minister and Cabinet was largely unobstructed by real checks and balances, and not the most institutionally or structurally representative of the Westminsters. New Zealand's Westminster system institutionalised delegative democracy for the executive. Only the relatively short parliamentary term of three years seemed a check on power. Though as Sir Robert Muldoon, perhaps New Zealand's most infamous practitioner of prime ministerial executive power submitted:

I can have an idea while shaving, have it endorsed in Cabinet that morning, put it into the House in the afternoon and have it become law by midnight. While I have that power - and I should - it needs to kept on a three-year leash. ${ }^{606}$

Like the British system, as opposed to the New Westminster system, New Zealand's executive has faithfully and culturally clung to conventions rather than legal documents. And yet it differs still. Without calculated or nationalistic intention New Zealand has developed, as Elizabeth McLeay has termed, a 'Wellington model' of executive government with 'distinctive constitutional characteristics' that arose due to 'the largely uncodified nature of the cabinet system of this small state' and in terms of horizontal

\footnotetext{
${ }^{604}$ Sir John Marshall, "Introduction" in The Reform of Parliament-Papers Presented in Memory of Dr Alan Robinson, Sir John Marshall (ed.), Wellington: New Zealand Institute of Public Administration, 1978 , p 10

${ }^{605}$ Zines, Constitutional Change in the Commonwealth, p 47

${ }^{606}$ Cited in Gerald Hensley, Final Approaches - A Memoir, Auckland: Auckland University Press, 2006, p 231
} 
accountability this meant that 'Prime Ministers in particular have a great deal of flexibility in how they construct their cabinets and, indeed, exercise power over these cabinets ${ }^{607}$ and within the executive over their nominal superior the Governor-General and colleagues in Cabinet.

The crucial power that the New Zealand executive carried until the advent of the Mixed Member Proportional system in the 1990s became cemented in the 1947-57 period when the two-party nature of New Zealand politics became entrenched and solidified the political executive's power over the legislature and the other institutional actors. For New Zealand Prime Ministers this was the real beginning of delegative democracy. New Zealand's single member plurality elected House of Representatives was made up of just eighty seats. The only deviation from traditional Westminster lower house was the fact that it contained four seats reserved for Māori elected from their own roll since 1867. Noted Māori scholar, Ranginui Walker, describes this as 'token' representation especially when compared to the late nineteenth-century Māori ideals of having a separate 'Māori Parliament' to deal with Māori issues and lands that would offer with the settler dominated House of Representatives a 'conjoint administration' under the 'law of God and the Queen' for New Zealand, which never eventuated as a credible entity or challenge to the established power structures of the colonial institutions. ${ }^{608}$ Though the Māori seats often helped sustain a Government, especially Labour, they rarely had the ability to interfere or influence executive power and therefore do not figure in this appraisal of executive institutions.

If there was a check on executive power it was convention. New Zealand had developed its own conventions, and though very influential, conventions by their very nature are malleable in the hands of those who hold power. This largely ignored era was pivotal in establishing conventions on dictatorial executive power and in demonstrating the ease with which personalist power was wielded by Prime Ministers of both Labour and National variety. Both Fraser and Holland did this to at least the extent of their counterparts in South Asia in the post-independence decade.

\footnotetext{
${ }^{607}$ Elizabeth McLeay, The Cabinet \& Political Power in New Zealand, Auckland: Oxford University Press, 1995, p 13 and $\mathrm{p} 33$

${ }^{608}$ Ranginui Walker, Ka Whawhai Tonu Matou - Struggle Without End, revised edition, Auckland: Penguin Books, 2004, pp 144-148 and pp 165-169
} 


\section{Head of State}

New Zealand, as was analysed in the previous chapter waited sixteen years, after all the other Dominions, to cross the constitutional bridge to independence which the Statute of Westminster engineered. Surveying the constitutional innovations to the office of Governor-General in the 1970s and 1980s, the legal scholar F. M. Brookfield commented that though New Zealand had been slow to adopt the Statute of Westminster they were 'slower still ... to bring the Governor-General's office up to date'. ${ }^{609}$ The Letters Patent of 1917 and the Royal Instructions which accompanied them which govern the powers of the Queen's Representative in New Zealand (which were virtually the same as those issued in 1907) meant that 'from 1907 to 1983 the content of the instruments creating the gubernatorial office and the standing instructions of the exercise of its powers remained virtually the same.... ${ }^{610}$ Alison Quentin-Baxter, Legal Consultant to the Prime Minister's Department, had quite a job in examining the existing and archaic Letters Patent and advocated many changes and recommendations which became the basis for the Letters Patent 1983. ${ }^{611}$ However, for the purposes of this study, the Letters Patent of 1917 from George V to "Our Right Trusty and Wellbeloved Cousin" in Wellington were those which by end of the selected period in 1957 had been functioning at Government House for forty years and were almost forty years away from a substantial overhaul.

The vice-regal position in New Zealand has been sardonically described by Sir Arthur Gordon, one of its early incumbents, as doing nothing more than 'performing the functions of stamp'. ${ }^{612}$ Though Governors and later Governors-General did perform other functions, the comment warrants reflection. Despite all Premiers and Prime Ministers until very recently having reverential regard for the Sovereign in person and being ready to perform and display every loyalty to the Monarch and the Monarchy this is not the attitude that the New Zealand Head of Government confers to the Sovereign's representative.

\footnotetext{
${ }^{609}$ F. M. Brookfield, "The Reconstituted Office of Governor-General”, New Zealand Law Journal, November 1985, p 357

${ }^{610}$ Brookfield, "The Reconstituted Office of Governor-General", pp 356-357

${ }^{611}$ Report by Alison Quentin-Baxter, Review of the Letters Patent 1917 Constituting the Office of Governor-General of New Zealand, Wellington: Cabinet Office, June 1980

${ }^{612}$ Sir Arthur Gordon (1880-1882) quoted in McLean, The Governors - New Zealand's Governors and Governors-General, p 9
} 
There is an almost inevitable temptation to construct a picture of the Governor-General of being analogous to the Queen in terms of constitutional and political power. Modern political scientists generally adhere to Andrew Ladley's description of New Zealand being a 'localised monarchy' meaning the 'constitutional domestication of the United Kingdom Crown in New Zealand'. ${ }^{613}$ New Zealand Governors-General eventually became viewed in David Lange's characteristically picturesque phrase as 'the Queen in drag $^{, 614}$ or at least were expected to be. The reality, as always in politics, is not so neat. The powers may have been localised, but the conditions, the culture and the constitutional circumstances and surroundings make it quite impossible to simply duplicate the Royal person to be accurately transplanted or implanted to her New Zealand Realm. The Governor-General does not have the advantages of being a Monarch such as the hereditary security of the position which insulates the Head of State from political pressures and preserves independence of experience and knowledge, especially when one considers that during Elizabeth II's reign she has already been served by thirteen Governors-General and thirteen Prime Ministers in her New Zealand Realm to date.

The truth is, as Bogdanor assesses, 'in Britain, the Sovereign is a working part of the constitution in a way that he or she cannot possibly be in an overseas realm' ${ }^{615}$ The same can be said in reverse - the Governor-General's involvement and role in the daily mechanics of the New Zealand system could not be realistically performed by the Queen on a long-term basis outside the United Kingdom. The Governor-General in New Zealand is not a working part of the constitution like the Queen is in Britain. The Crown is constitutionally divisible, but for practical purposes the Queen is not. In Sir Zelman Cowen's appraisal, a former Australian Governor-General, with the divisible Crown there is a 'shared monarchy', where the Queen acts in a 'different capacity in each realm'. ${ }^{616}$ The same can be said of Governors-General who have quite different

\footnotetext{
${ }^{613}$ Andrew Ladley, "The Head of State" in New Zealand Politics in Transition, Raymond Miller (ed.), Auckland: Auckland University Press, 1997, pp 53-55. Ladley's views are continued in his chapter "Who Should be Head of State?" in Building the Constitution, Colin James (ed.), Wellington: Institute of Policy Studies, 2000, pp 267-265 and Noel Cox and Raymond Miller, "Head of State" in New Zealand Government and Politics, $4^{\text {th }}$ edition, Raymond Miller (ed.), Melbourne: Oxford University Press, 2006, p 133

${ }^{614}$ David Lange cited in Gavin McLean, "From Cocked Hats to Designer Frocks - The 'Queen in Drag' in Twentieth-Century New Zealand' in Exploring the British World: Identity, Cultural Production, Institutions, Kate Darian-Smith (ed.), Melbourne: RMIT Publishing, 2004, p 979

${ }^{615}$ Bogdanor, The Monarchy and the Constitution, $\mathrm{p} 289$

${ }^{616}$ Sir Zelman Cowen, "The Crown and Its Representative in the Commonwealth", Commonwealth Law Bulletin, Vol. 18, January 1992, p 306
} 
expectations and roles in the respective realms where the office is required. ${ }^{617}$ For all Commonwealth Governors-General the responsibility ultimately lies with them since notwithstanding being the Queen's personal representative the Governor-General 'does not seek instruction from her, but acts on his own authority, informing her when appropriate of what he has done'. ${ }^{618}$ Therefore the Governor-General is a 'free-agent' of the Queen in theory but not so free of the 'local' agent in reality.

New Zealand's circumstances were and still are quite different for a Head of State to operate compared to Britain, which became evident very early on. Writing on the nineteenth century era of responsible government in the colony, D. K. Fieldhouse has articulated the autochthonous realities of the New Zealand executive situation that still resonate today. Instead of having to abide by all the Royal Letters of the law it was the political coarseness of power on the ground that counted.

In every case it was the facts of the local situation, and the conventions built up locally in the past, that dictated events. The Governor had less share in actual government, and was certainly less well informed on ministerial policy, than the Sovereign in Britain ... It was ... predictable that the colony would develop, not into a constitutional monarchy of the British type, in which both monarch and upper house would retain at least some constitutional significance, but into a special form of quasi-monarchical system, in which the upper house became a nonentity or ceased to exist, and the Governor became a figurehead with purely decorative functions. And this, indeed, has proved to be the special characteristic of 'Dominion Status' in New Zealand - a unicameral legislature with the greatest possible concentration of power in the hands of the ministers of the moment. ${ }^{619}$

With attitudes ranging from contempt to considerateness, one attitude is constant: New Zealand Prime Ministers have not been prepared to accept the Governor-General as a check on their executive power. New Zealand's most prominent public law specialists argue that the modern view that the Governor-General 'represents a substantial check on the excesses of executive government ... is ... wrong', articulating a contemporary New

\footnotetext{
${ }^{617}$ See David Butler and D. A. Low (eds.), Sovereigns and Surrogates - Constitutional Heads of State in the Commonwealth, New York: St. Martin's Press, 1991

${ }^{618}$ Cowen, "The Crown and Its Representative in the Commonwealth", p 310

${ }^{619}$ Fieldhouse, "Autochthonous Elements in the Evolution of Dominion Status: The Case of New

Zealand", p 107
} 
Zealand convention on the limitations of the Governor-General's power. ${ }^{620}$ The Governor-General holds office at "the Queen's pleasure" and therefore is beholden to the local Prime Minister who directly advises Her Majesty on the appointment and term of office leaving the Governor-General's position and tenure potentially insecure and subject to political pressure. ${ }^{621}$ And yet in New Zealand's small unitary and unicameral system untroubled by rigid and written constitutional devices it is the Governor-General that stands alone on the last legal check on executive power. Analysts of New Zealand often argue that Australia's 1975 constitutional crisis over Sir John Kerr's dismissal of the Whitlam administration would be highly improbable to occur in New Zealand since there is no federal or strong bicameral system as in Australia, which created the political and constitutional uncertainty that pushed the Governor-General to action. ${ }^{622}$ However, the federal and strong bicameral elements of the Australian system are there to be a check and perform institutional accountability on the executive, represented at the top by the Governor-General.

New Zealand's political system has even fewer forms of institutional and horizontal accountability, which theoretically places greater potential for the Governor-General in the absence of such institutional factors to be a check on the executive as the lawful guardian of the constitution. As will be discussed below this was the view of GovernorGeneral Sir Cyril Newall during the Fraser era. Though generally unappreciated in the remote Realm with its "executive purity" it "would be more consistent with his role in public life and his oath of office to recognise that the Governor-General protects the constitution, and that he alone is eligible to provide a measure of oversight in the otherwise self-regulated executive government' prevalent in the simple and institutionally uncluttered case of New Zealand. ${ }^{623}$ Though Dame Catherine Tizard states the ideal that a Governor-General 'is the person who gains by successfully passing the parcel' the preservation and protection of the constitution is ultimately the

\footnotetext{
${ }^{620}$ Sir Geoffrey Palmer and Matthew Palmer, Bridled Power - New Zealand's Constitution and Government, $4^{\text {th }}$ edition, Melbourne: Oxford University Press, 2004, p 56

${ }^{621}$ Sir John Kerr's prominent example in Australia sent shockwaves around the Commonwealth in 1975 when Prime Minister Gough Whitlam arguably could have advised the Queen to dismiss her Australian Governor-General and thus forestall his own dismissal as Prime Minister. See Vernon Bogdanor and Geoffrey Marshall, “Dismissing Governor-Generals” Public Law, 1996, pp 205-213. Also see Brookfield, "The Reconstituted Office of Governor-General", pp 359-360 which discusses ways of removing the constitutionally undesirable 'vulnerability' of the office in New Zealand.

${ }^{622}$ For Sir John Kerr's version of a Governor-General's powers see Sir John Kerr, Matters of Judgement - An Autobiography, Melbourne: Macmillan, 1978 and Sir Garfield Barwick, Sir John Did His Duty, Wahroonga: Serendip Publications, 1983

${ }^{623}$ R. Q. Quentin-Baxter, “The Governor-General's Constitutional Discretions: An Essay Towards a Redefinition”, Victoria University of Wellington Law Review, Vol. 10, 1980, p 314
} 
Governor-General's responsibility and duty, especially in the institutionally simplistic and unwritten New Zealand Westminster system, even if it means an undesirable confrontation with the responsible advisors to the Crown. As Brookfield argues:

While the notion of a nominal Head of State who keeps entirely free of political involvement may be adequate when times are normal, a stronger doctrine may be needed when they are not. After all, New Zealand may not always be governed by politicians who are on the side of angels and it may well be governed (not to say governed well) by those who in good faith confuse the preservation of their political power with the national interest. Whatever the ensuing unpleasantness, we may need the Governor-General's intervention yet... ${ }^{624}$

New Zealand, just as it had resisted constitutional change with the Statute of Westminster at the 1926 Conference, also resisted the proposal from the other Dominions that they themselves initiate and recommend who was to be their GovernorGeneral rather than the British Secretary of State. Another important change emanating from the other Dominions at the conference, from which New Zealand recoiled, was that the Governor-General should represent just the Monarch and the British Government, who would be represented by the British High Commissioner - it was not till 1941 that this culturally permissible but constitutionally undesirable duality ended. The Governor-General ceased to be an agent of the British Government, instead becoming an agent of the New Zealand one. This reluctance to take on the prerogative of choosing the Head of State should not be viewed as political impotence on the part of the New Zealand executive. Even though New Zealand Prime Ministers knew they could appoint a "local" if they so desired, they did not.

New Zealanders it seemed preferred British aristocrats, preferably with a military or agricultural background. When New Zealand-raised war hero Lord Freyberg was due to retire members of the British establishment suggested in official circles in Wellington (not London) to replace him included Lord Tweedsmuir (novelist and at the time Governor-General of Canada), Admiral Lord Fraser, Sir Denys Lowson (Lord Mayor of

\footnotetext{
${ }^{624}$ F. M. Brookfield, "No Nodding Automaton: A Study of the Governor-General's Powers and Functions", New Zealand Law Journal, December 1978, p 506
} 
London) and Viscount Knollys - with not a New Zealander in sight. ${ }^{625}$ Sidney Holland even cancelled a Cabinet meeting to rush to the airport to plead with the Lord Mountbatten, former Viceroy of India, with his impeccable credentials in New Zealand eyes, to become Governor-General of the Queen's most southern realm, though the offer was declined with courteous alacrity. ${ }^{626}$

However, when the head of the Prime Minister's Department notified the incoming Prime Minister in December 1949 that in New Zealand 'the Governor-General is not informed of Cabinet proceedings. In the United Kingdom, and it is understood also in other Commonwealth countries, the King or his representative, as the case may be, is kept advised. He receives copies of Agenda, of papers and of the Minutes of the Cabinet discussion. It is for consideration whether or not some such regular advice should not be instituted here' the normally exuberant Holland displayed reluctance evident in all Prime Ministers on such matters and allowed the matter to be dropped. ${ }^{627}$ Bagehot's dictum of the Monarch's right to be consulted, to encourage and to warn did not seem to happen for her representative in New Zealand. The political reality was quite askance from that English theory as Sir John Marshall observed with his high level and long political experience:

[T]he Governor-General's right to be consulted, to encourage and to warn are not exercised in any formal or regular way. The Prime Minister does not report regularly to the Governor-General as the British Prime Minister reports to the Queen. In 20 years as a Minister, I seldom attended at Government House for consultation, even less for encouragement and never for warning. Even when I was Prime Minister the consultations with the Governor-General were infrequent, although our relationship, socially and on state occasions, was cordial. The Governor-General presides at the meetings of the Executive Council each week when he is in Wellington, but these are formal meetings for the signing of Orders-in-Council and the making of Regulations on the advice of the Ministers concerned ... the convention that the Governor-General acts on the advice of his Ministers is firmly established in New Zealand. ${ }^{628}$

\footnotetext{
${ }^{625}$ Appointment of Governors-General 1947-57, AAFD 811 232A 27/1/4 Part 2, ANZ

${ }^{626}$ Ziegler, Mountbatten - The Official Biography, p 532

${ }^{627}$ McIntosh to Sidney Holland - 2 December 1949, AAFD 816/1A 10/1, ANZ

${ }^{628}$ Sir John Marshall, "The Power of Dissolution in New Zealand”, The Parliamentarian, Vol. LVIII, No. 1, January 1977, p 15. Marshall in a hand written note while in the Holland administration stated that the 'Gov. Gen. has not got the King's traditional right to encourage, advise and warn ministers', undated. In
} 
Even the Executive Council meetings where the Governor-General had at least had the chance of meeting some of his Ministers for Orders-in-Council there still applied the so called "one-cigarette" rule, where His Excellency 'signed papers, chatted to the Prime Minister for as long as it took to smoke a single cigarette then let the politicians go back to running the country'. ${ }^{629}$

New Zealand Prime Ministers of this delegative democracy era enjoyed and often respected the inhabitants of Government House but did not brook interference in their realm of executive power. For Prime Ministers, as responsible government developed in New Zealand, the Sovereign's representative 'ceased to fulfil the positive role laid down for him by imperial authority, and had become, in all important respects and under normal circumstances, no more that the titular head of his government' ${ }^{630}$ The first New Zealand born Governor-General was Sir Arthur Porritt who took his commission in 1967, twenty years after the adoption of the Statute. Porritt, who had been part of the Royal Household as Sergeant-Surgeon to the Queen proclaimed when he returned home that 'all New Zealanders are born "Queen's Men" with a deep respect and warm affection for Her Majesty' ${ }^{631}$ In this era in the executive arena New Zealand Ministers may well have been culturally disposed to be the "Queen's men", but they certainly were not culturally, politically or institutionally the "Governor-General's men". The executive, including the Queen's Representative, were compelled by convention and reality to be the "Prime Minister's men".

In Britain the monarchy as R. Quentin-Baxter states 'is always at the centre of British political and constitutional life' and though 'there is no essential difference between the Queen's powers and those of a Governor-General: the difference lies in their relationship with their respective governments'. ${ }^{632}$ In New Zealand government of this era the Queen, as a 'dignified' part of constitutional pageantry, is culturally inviolable while her representative became institutionally irrelevant. The decorated soldiers,

Sir John Marshall Papers MS 1403-069/3, Alexander Turnbull Library, Wellington, New Zealand [henceforth ATL]. Later Governors-General right to the present also complained about the 'infrequency of prime ministerial briefings' see McLean, The Governors - New Zealand's Governors and GovernorsGeneral, p 319

${ }^{629}$ McLean, The Governors - New Zealand's Governors and Governors-General, $\mathrm{p} 255$

${ }^{630}$ Fieldhouse, "Autochthonous Elements in the Evolution of Dominion Status: The Case of New Zealand", p 87

${ }^{631}$ McLean, The Governors - New Zealand's Governors and Governors-General, pp 279-281

${ }^{632}$ Quentin-Baxter, "The Governor-General's Constitutional Discretions: An Essay Towards a Redefinition”, p 297 
noblesse oblige aristocrats and former British politicians that arrived on New Zealand shores soon found the impotence of their vice-regal position and were reduced, like Gordon before them, to often learning of the executive actions of their Ministers like everyone else 'from the morning newspaper'. 633

\section{The Forgotten Newall Doctrine}

With the end of their double role in 1941 Governors-General ceased symbolically to be an agent of Britain, but instead became an agent of the New Zealand Prime Minister and Cabinet. The New Zealand executive now determined their nominal superior and the country's constitutional guardian without the vexations of elections or the rigour of transparency. There was only a mirage of consultation with the Palace and rarely, if ever, with anyone outside of Cabinet. As much it was nationalistically unpalatable for a Labour Prime Minister like Norman Kirk in the 1970s to return to having wealthy British aristocrats as Governor-General, at least they would be from his perspective independent of party bias, which he suspected that New Zealand's first resident Governor-General Sir Denis Blundell had with the National Party. ${ }^{634}$ Indeed Kirk had 'great respect and affection' for former Governor-General Lord Ballantrae for example who was 'completely non-political' and even mended the bellows when he visited the Māori-speaking monocle-sporting Ballantrae in Scotland, who was remarkably the third generation of his distinguished family to serve as the Sovereign's representative in New Zealand. $^{635}$ Kirk's attitude, as Leader of the Opposition, was primarily targeted at the Governor-General's neutrality according to his private secretary -

He is ... far from happy that the Governor-General, Sir Denis Blundell, was appointed under a National Government and that he and Jack Marshall [presently Prime Minister] are lifelong friends. He thinks aloud about the possible implications and whether there is any way the situation can be changed. Perhaps Blundell's term could be cut short, and "Charlie Boy" - Prince Charles - could be persuaded to take over as Governor-General. ${ }^{636}$

\footnotetext{
${ }^{633}$ Gordon cited in Fieldhouse, "Autochthonous Elements in the Evolution of Dominion Status: The Case of New Zealand", p 91

${ }^{634}$ Diary entry, 27 September 1972 in Margaret Hayward, Diary of the Kirk Years, Wellington/Queen Charlotte Sound: Reed/Cape Catley, 1981, p 62

${ }^{635}$ Diary entry, 5 February 1974 in Hayward, Diary of the Kirk Years, p 213

${ }^{636}$ Diary entry, 11 December 1972 in Hayward, Diary of the Kirk Years, p 106
} 
The crowning verification that the person occupying Government House was an agent of the Prime Minister was in 1977 when National Prime Minister Muldoon felt brazen enough to recommend to the Queen the appointment of long-time National leader and former Prime Minister, Sir Keith Holyoake, despite him still being an MP and Cabinet minister. The selection aroused the suspicion that the appointment was as act of recompense to a mentor who had helped Muldoon's career so much. ${ }^{637}$ The move was unprecedented and was not greeted with enthusiasm in the press or by the public and met with understandable consternation by the Opposition, who almost totally boycotted Government House and threatened to advise the Queen to recall Holyoake. ${ }^{638}$ The Queen herself was reputedly chary of what could be naturally construed as a political appointment and though there were examples of such appointments in other Commonwealth countries it did, thanks to Holyoake's obvious and close party and government associations create, the constitutionally detrimental impression that the Governor-General of New Zealand was 'in the pocket of the government' ${ }^{639}$

The above illustrates the constitutional vulnerability of a Governor-General, when viewed or constructed as a mere pawn in the Prime Minister's hands. This is especially pertinent when one remembers the relative "purity" and power of the Westminster executive in New Zealand, unchecked and untroubled by the constitutional apparatus prevalent in other New Westminsters. As the most recent analysis of the GovernorGeneral attests: 'once seen as an instrument of imperial will, the Governor-General is occasionally now seen as a constitutional safeguard against executive despotism' who can 'intervene to preserve the constitutional order itself'. ${ }^{640}$ They are, to use Dame Catherine Tizard's more homely analogy 'constitutional mums'. ${ }^{641}$

Though easy to ignore, the powers of the Crown are legally real despite the convention that they are exercised on the advice of elected and responsible ministers. In reflection of those powers, that redoubtable and mercurial colonial statesman Sir George Grey campaigned in his latter years for 'an elective governorship', though this distinctive

\footnotetext{
${ }^{637}$ For an appraisal of the close Holyoake-Muldoon relationship see Barry Gustafson, "The Sorcerer and His Apprentice" in Sir Keith Holyoake - Towards a Political Biography, Margaret Clark (ed.), Palmerston North: Dunmore Press, 1997, pp 195-205

${ }^{638}$ McLean, The Governors - New Zealand's Governors and Governors-General, p 299

${ }^{639}$ See McLean, The Governors - New Zealand's Governors and Governors-General, pp 297-301; Barry Gustafson, His Way - A Biography of Robert Muldoon, Auckland: Auckland University Press, 2000, pp 208-209 and Gustafson, The First 50 Years - A History of the National Party, pp 130-131

${ }^{640}$ Cox and Miller, "Head of State" in New Zealand Government and Politics, p 134

${ }^{641}$ Dame Catherine Tizard, Crown and Anchor: The Present Role of the Governor-General in New

Zealand, Wellington: Friends of the Turnbull Library, 1993, p 4
} 
proposal was not well received in Britain or New Zealand. ${ }^{642}$ The Letters Patent stipulates that the Governor-General 'may exercise all powers lawfully belonging to Us' over the legislature giving a Governor-General their constitutional authority. ${ }^{643}$ The Governor-General was granted from Clause V of Royal Instructions the potentially intimidating, but clear power to reject advice of the Cabinet if the situation justified it.

In the execution of the powers and authorities vested in him, the GovernorGeneral shall be guided by the advice of the Executive Council, but if any case he shall see sufficient cause to dissent from the opinion of the said Council, he may act in the exercise of his said powers and authorities in opposition to the opinion of the Council, reporting the matter to Us without delay, with the reason for his so acting.

In any such case it shall be competent to any Member of the said Council to require that there be recorded upon the Minutes of the Council the grounds of any advice or opinion that he may give upon the question. ${ }^{644}$

Therefore though in quarantine the Governor-General had the power to intervene and reject the advice of his Ministers. ${ }^{645}$ However, the practice in New Zealand has rarely excited such impressive interpretations either from the Governors-General themselves or the elected members of parliament. It would be a mistake though to completely negate those powers since the Instructions 'leave him free in law to act or not to act, in opposition to the advice of the Executive Council or of individual Ministers'. ${ }^{646}$ Speaking from experience Lord Cobham asserted that in New Zealand's constitutional order 'to relegate the Governor-General to the status of a mere powerless figurehead is to place the whole Constitution in the power of a possibly unscrupulous administration

\footnotetext{
${ }^{642}$ Fieldhouse, "Autochthonous Elements in the Evolution of Dominion Status: The Case of New Zealand", p 95

${ }^{643}$ Clause X, Letters Patent Relating to the Office of Governor-General, created 11 May 1917

${ }^{644}$ Clause V, Instructions Passed Under the Royal Sign Manual and Signet to the Governor-General and Commander-in-Chief of the Dominion of New Zealand, created 11 May 1917

${ }^{645}$ Even with the introduction of the Letters Patent 1983 and the Constitution Act 1986 some legal scholars still argue that the Governor-General's right to refuse assent remains. See for example David J. Slight, "Refusal of Assent - A Suicidal Safeguard?", New Zealand Law Journal, May 1987, pp 146-147 ${ }^{646}$ Brookfield, "No Nodding Automaton: A Study of the Governor-General's Powers and Functions", pp 497-498
} 
... I contend that it is still part of his powers, and his bounded duty, to see that the traditional usage of the constitution is observed'. ${ }^{647}$

What is involved in being a "constitutional mum" and what exactly is the "traditional usage of the constitution" in New Zealand? The one commonality of all GovernorsGeneral in the Commonwealth is that despite the varying degrees of legal definition there is an ambiguity that surrounds the practical and real powers of the position. In the New Zealand position Sir Denis Blundell noted in the 1970s the reality that his office was governed by convention and yet he had 'never seen them collected in any writing'. ${ }^{648}$ New Zealand still looked through dust coated tomes of English legal doyens Dicey, Anson and Jennings or even letters in The Times between British establishment figures like Viscounts Samuel and Waverly for constitutional guidance in dealing with their local circumstances, despite the limited comparability. ${ }^{649}$ However, one of the Blundell's forerunners outlined a brief, but constitutionally rich note and doctrine on the New Zealand Governor-General's constitutional role, which others had hoped for. Marshall of the Royal Air Force Sir Cyril Newall is one of the country's most unknown Governors-General: Dame Silvia Cartwright's overview of her office and thirty-three predecessors neglects Newall completely. ${ }^{650}$ And yet Newall was the first Governor-General to be solely the agent of the New Zealand when he entered office in February 1941. Newall, who had just taken part as Chief of the Air Staff with the Battle of Britain not only applied his military knowledge to helping New Zealand's war effort, but also to largely unknown stratagems of defending the constitutional rights of the Governor-Generalship from prime ministerial assaults.

Newall's term which announced and then led to the adoption of the Statute of Westminster contains one of the last attempts of a New Zealand Governor-General to assert his prerogative and right to be consulted, to encourage and to warn and therefore act as a "constitutional mum" though, as will be shown below this was not the "traditional usage" of a Governor-General's actual powers within the New Zealand

\footnotetext{
${ }^{647}$ Viscount Cobham, "The Governor-General's Constitutional Role" in Readings in New Zealand Government, L. Cleveland and A. D. Robinson (eds.), Wellington: A.H. \& A.W. Reed, 1972, p 86

${ }^{648}$ Sir Denis Blundell, "Some Reflections upon the Office of Governor-General in New Zealand", Victoria University of Wellington Law Review, Vol. 10, 1980, p 200

${ }^{649}$ Copies of Letters in The Times, February 1950, between former Liberal leader Lord Samuel (formerly Sir Herbert Samuel) and former wartime Chancellor of the Exchequer Lord Waverly (formerly Sir John Anderson) in AAFD 811 176C 1/12/1, ANZ

${ }^{650}$ Dame Silvia Cartwright, "The Role of the Governor-General”, New Zealand Centre for Public Law, Occasional Paper No. 6, October 2001, pp 1-20
} 
executive. Nearing the end of his term Newall recorded in writing a clear and constitutionally correct, but practically difficult in New Zealand's executive environment, interpretation of a Westminster and Wellington model GovernorGeneral's duty:

The Governor-General, as the King's Representative, has the right to consider the propriety of exercising his constitutional authority or discretionary powers to refuse assent to a course of action advised by his Ministers in two classes of cases:

a) If he thinks that such a course of action offends against the law of the Constitution and is illegal. In such cases it is proper for the Governor-General to obtain the advice of the Law Officers and if they advise that the proposed course of action is illegal then it is his constitutional duty to refuse assent.

b) If he thinks that the course of action, while not offending against the letter of the law, is such as to offend against the spirit of fundamental principles of the Constitution.

In such cases it would also be within his discretion, as the ultimate guardian of the Constitutional Government of the country, to refuse his assent, but before making a decision to exercise his discretion, he should satisfy himself, not only that he could find alternative Ministers prepared to accept responsibility for his decision and to go to the country in support of it, but also that they had sure prospect of winning the General Election and continuing in office. Otherwise, the Governor-General would have exposed the country to the turmoil of a General Election for no purpose and he would have gravely impaired the prestige of the Governor-General's office. ${ }^{651}$

This was an attempt to institutionalise the role of the Governor-General with the 'efficient' purpose of defending the constitution. Newall had every intention of complying with his own dictum and could rely on the ancient statutory and royal powers to defend his bold statement - though it is not clear who this declaration was intended for, whether for posterity, Prime Ministers or future proconsuls it was a rare clarion call of a Governor-General's constitutional powers over the New Zealand convention of being a mere "stamp". Newall's construal may well have been based on his largely overlooked, but constitutionally eventful tenure. Though Newall's term is slightly before the focal period of this thesis there are crucial constitutional practices

${ }^{651}$ Minute by Sir Cyril Newall, 16 March 1946, G48 21 P/6, ANZ 
which shaped the office for decades to come, since his example was rarely honoured by his successors except in avoidance.

In 1941, early in his term, Newall was asked to remit the orders to flog four escaped prisoners who had assaulted prison guards. The Cabinet recommended the GovernorGeneral remit the sentence since it was against flogging despite it being legal and the sentences were upheld in the Court of Appeal. Newall protested that he could not therefore sign since there were no 'mitigating circumstances' and he had not been properly consulted. ${ }^{652}$ It was an occasion, which as Keith Sinclair argues was 'probably the last on which a Governor-General did not act on ministerial advice'. ${ }^{653}$ Fraser told the Cabinet from overseas that they 'should on no account accept the GovernorGeneral's refusal to act of ministerial advice'. ${ }^{654}$ As Gavin McLean recounts Newall 'stuck to his guns' and eventually Nash, the acting Prime Minister, demurred and Cabinet gave in, since with an election coming soon they did not want a 'public scrap with the Governor-General'. The solution was that the Government publicly announced it would abolish flogging, making it acceptable to Newall to sign the remission orders and thus both parties 'saved face'. ${ }^{655}$

Newall was also a stickler for protocol reminding ministers not to broadcast policy or personnel information which had not passed through him first. Newall was quite prepared to upbraid Fraser in the middle of the burdens of his war leadership that ministers must submit their resignations in person since they 'were the King's Ministers and that, it was a matter which required something more that an ordinary typewritten advice to the Governor-General to accept their resignations'. Fraser even apologised and assured the New Zealand Commander-in-Chief that 'the necessary precautionary measures have been taken to ensure that there will be no recurrence of this unfortunate oversight'. It is also worth noting that the King was informed directly by Newall about every change in his New Zealand Ministry and acknowledged so. ${ }^{656}$

Perhaps the most fascinating and central example of Newall's doctrine of being able to question a Government's 'course of action, while not offending against the letter of the

\footnotetext{
${ }^{652}$ McLean, The Governors - New Zealand's Governors and Governors-General, pp 245-246

${ }^{653}$ Sinclair, Walter Nash, p 204

${ }^{654}$ McLean, The Governors - New Zealand's Governors and Governors-General, $\mathrm{p} 246$

${ }^{655}$ McLean, The Governors - New Zealand's Governors and Governors-General, $\mathrm{p} 246$

${ }^{656}$ Letters and Notes at Government House between October 1942 and October 1943 in G 48 Box 21 $\mathrm{P} / 5(3), \mathrm{ANZ}$
} 
law, is such as to offend against the spirit of fundamental principles of the Constitution" ${ }^{657}$ was over the abolition of the "Country Quota" in 1945. The "Country Quota", which had been part of the New Zealand electoral system since the $1880, \mathrm{~s}$ added a fictitious amount (then twenty-eight per cent) to the rural population to balance it against urban centres. The quota worked 'to the prejudice of the largely urban Labour Party' while it continuance favoured the farmer dominated National Party, who saw the rural sector as the backbone of the country. Fraser caustically described the quota as the 'vermiform appendix of Toryism' and wished its replacement with the 'principle of one man, one vote'. ${ }^{658}$ The Labour Government had been concerned over its chances of winning the 1946 General Election and saw the benefit of getting the Electoral Amendment Bill 1945 through to help its chances of staying in power since it would eventually create six more urban seats to the loss of the same number of rural electorates. National vigilantly opposed the Bill through thirty-four divisions and compelled the Labour Government to use parliamentary tactics of urgency and closure. ${ }^{659}$ The Bill eventually passed the gauntlet of the House of Representatives at almost 3.30am 3 November 1945 where 'every clause was challenged by the Opposition'.660 The abolition of the "Country Quota" now is almost completely forgotten, despite it arguably being the most radical change to the electoral system of New Zealand till the adoption of proportional representation fifty years later. And yet for such a significant change to the electoral dynamics of the country the Labour Government 'had no mandate for changing the electoral laws' ${ }^{661}$

A few days after the Bill cleared, an editorial in the capital's morning daily speculated on the Governor-General's role and responsibilities:

It is of importance that the heavy responsibilities attached to the high office of Governor-General should be clearly understood. The office is part of the constitutional system of the country, the appointment to it being made on the recommendation or with the consent or approval of the Government of the day. Certain powers are attached to the office, among them being the signing of Bills

\footnotetext{
${ }^{657}$ Minute by Sir Cyril Newall, 16 March 1946, G48 21 P/6, ANZ

${ }^{658}$ For more details on the "Country Quota" see Scott, The New Zealand Constitution, pp 20-21 and Bassett and King, Tomorrow Comes the Song - A Life of Peter Fraser, p 302

${ }^{659}$ John E. Martin, The House - New Zealand's House of Representatives 1854-2004, Palmerston North: Dunmore Press, 2004, p 215 and Gustafson, The First 50 Years - A History of the National Party, p 52

${ }^{660}$ Evening Post, 3 November 1945

${ }^{661}$ Scott, The New Zealand Constitution, p 20
} 
which have been passed by Parliament, and requiring the Governor-General's signature as the representative of the King. It can be assumed that these powers would not have been granted unless it had been contemplated that they might be used on occasion as the interests of the community might demand. It is considered by those affected, or likely to be affected, by the amendment of the electoral law now under review, that such an occasion has now arisen. What apparently is being sought is that the Governor-General by virtue of the authority he holds should abstain from placing his signature to the measure amending the electoral laws until the people as a whole have been consulted as to the changes proposed.

The aptly named Dominion newspaper was calling upon the constitutional guardian to act to preserve to use in Newall's words 'the spirit of fundamental principles of the Constitution'. Whatever the arguments for and against the "Country Quota", the abolition of it would significantly alter the existing constitutional and electoral status quo in the country. Newall in the proceeding days had received representations from the New Zealand Farmers' Union. The issue gained widespread public attention and the Farmers' Union and interested parties raised the princely sum of $£ 250,000$ to 'fight abolition' ${ }^{662}$ Their President, W.W. Mulholland, believed the Electoral Amendment Bill 'gives grave affront to a great many loyal and industrious subjects of His Majesty the King in New Zealand'. Mulholland wasted no time in putting an extraordinary option before the Governor-General:

If your Advisors are unwilling to have the legislation delayed, and the question thus decided, we would respectfully ask Your Excellency to cable His Majesty appealing to him to intercede with his New Zealand Government to follow the constitutional practice in regard to major changes in national policy, and to put the question before the electors at a General Election in which this matter is made a major issue, before proceeding with the Bill. ${ }^{663}$

To this and similar letters Newall's Official Secretary sent a standard courteous, correct, but ultimately negative letter: '...I am directed by His Excellency to inform you that the matter raised therein does not appear to fall within his constitutional authority as

\footnotetext{
${ }^{662}$ Evening Post, 8 November 1945

${ }^{663}$ Letter to Governor-General from W.W. Mulholland (Dominion President of NZ Farmers' Union), 1 November 1945, G48 Box 21 P/5(5), ANZ
} 
Governor-General, but that your communication has been forwarded to his Responsible Advisers for their consideration' ${ }^{664}$ However, despite it seeming as if the GovernorGeneral was avoiding the issue or pouring cold water on the farmers' concerns, Newall did in fact act behind the scenes. The day after receiving the Dominion President of the Farmers' Union Newall met the Prime Minister to acquaint him of his misgivings over the proposed alterations to the electoral system.

Newall was concerned as to sign 'any measure which might not be in accordance with the wishes of the majority'. Fraser replied that 'if the people so wished they could turn them out at the next election': the mantra of all New Zealand Prime Ministers when having to put through difficult policy. He attempted to mollify the Air Marshall that his concerns 'would always receive his personal and careful consideration and that he would refer them to his colleagues and the Government' and both the Head of State and Head of Government appreciated the 'seriousness of the matter'. ${ }^{665}$ On the same day a telegram warned Government House that 'revolution' would occur if abolition proceeded and warned the King's Representative that 'we will fight if you sign' ${ }^{6} 66$

On 6 November 1945 Newall did in fact communicate with the King's Private Secretary and apprised him with resigned accuracy of the constitutional tensions and issues in George VI's realm beyond the seas.

The provisions of the Bill, which had not previously been communicated to the people, were in my opinion designed by the Government with the intention of securing their return to Parliament in November, 1946, having in mind the swing of public opinion against them at the last General Election. It has been most sternly contested by the Opposition at all stages in its passage through the House and has roused angry protest throughout the Dominion not only in the Press (which is almost exclusively anti Labour Party) but by the very great majority of people in the rural districts and by many thousands residing in the cities...The Electoral Act has been in existence since 1881, and the country quota (although it has been altered on two occasions) has come to be regarded more or less as part of the Constitution. Notwithstanding the unpopularity of the Bill, however, it does not seem to infringe the Constitution Act and the Government are strictly

\footnotetext{
${ }^{664}$ For example to Mulholland, 5 November 1945, G48 Box 21 P/5(5), ANZ

${ }^{665}$ Minute by Newall, 2 November 1945, G48 Box 21 P/5(5), ANZ

${ }^{666}$ Telegram from Richard Cobbe to Governor-General, 2 November 1945, G48 Box 21 P/5(5), ANZ
} 
within the letter of the law in enacting such legislation without prior reference to the people. I discussed with my Prime Minister the representation made by the New Zealand Farmers' Union and suggested that in view of the strong objection to the Bill and the fact that representation in Parliament was the most prized possession of people under democratic governments he might consider withholding it for the General Election in November, 1946, or alternatively that he make it the subject of a referendum this year. Neither of these proposals he has seen fit to adopt and I am left with no option but to assent to the Bill when it is submitted to me. This I intend to do. I do not propose to make any formal representations to the King in the matter, but as the Bill has aroused such intense feeling and bitter protest throughout the country I feel that His Majesty would like to be acquainted with the circumstances. ${ }^{667}$

Newall had exercised to the full his right to be consulted, to encourage and to warn and he stayed true to his doctrine and demonstrated throughout his tenure that a GovernorGeneral is the custodian of "the spirit" of the constitution that should not be ignored by the elected executive. Though his objections over the "Country Quota" were ultimately to no avail he reminded his "responsible advisors" of a Governor-General's constitutional importance, though not quite achieving the centrality of the King in the British system. Though New Zealand Governors-General 'send regular private letters' to the Sovereign as shown above it was becoming implicit 'that the actual responsibilities of constitutional head of state lie with the Governor-General' ${ }^{668}$ Fraser was able through his reply to Mulholland on Newall's behalf to outline the constitutional position in New Zealand with technical and practical reality:

It is noted that you ask His Excellency to request his Advisors to reconsider their decision to pass the Electoral Amendment Bill at this time. As you are aware this measure, which the Government regard as one of major importance has now passed the House of Representatives and it is the intention of the Government that it should proceed through the remaining Parliamentary stages. Your request to His Excellency to prorogue Parliament and hold an election is also noted. In this connection I have to advise you that such action on the part of His

\footnotetext{
${ }^{667}$ Telegram from Newall to King's Private Secretary (Sir Alan Lascelles), 6 November 1945, G48 Box $21 \mathrm{P} / 5(5)$, ANZ

${ }^{668}$ Antony Wood, "New Zealand" in Butler and Low (eds.), Sovereigns and Surrogates - Constitutional Heads of State in the Commonwealth, p 121
} 
Excellency in the present circumstances would be quite unconstitutional since the Electoral Amendment Bill is in no way contrary to the laws of New Zealand, nor does it violate the spirit of the Constitution. ${ }^{669}$

Newall had little left of his term after this constitutional scuffle and a barony awaited him on his return to the "Old Country". This forgotten Governor-General had attempted to forge a greater institutional 'efficient' role as defender of the constitution and a sense of constitutional purpose to his high office, but his successors were not generally inclined to withstand the inexorable flow in New Zealand of political and constitutional primacy to the Prime Minister and Cabinet. Those who immediately followed him to become the first Governors-General of the independent realm of New Zealand favoured a more observational, passive and culturally simplified role to following the often politically uncomfortable, but constitutionally courageous and ultimately correct, clauses of the "Newall Doctrine". This was in spite of the crucial constitutional and cultural developments that occurred in the decade that followed the adoption of the Statute of Westminster.

Fraser's announcement that Lieutenant-General Sir Bernard Freyberg VC would succeed Newall was hugely popular. An appointment described by Fraser's biographers as a 'political master-stroke' due to Freyberg's childhood experience of New Zealand and more popularly the fact that he was a 'legend amongst his troops' as the man who had led so many New Zealand servicemen and 'a close personal friend' of the Prime Minister. ${ }^{670}$ As will be discussed below Freyberg though naturally involved in helping with the "Defence of the Realm" was conspicuous by his constitutional inactivity and acquiescence to prime ministerial command despite there being huge developments in this period. These included the succession of a new Sovereign, the abolition of the upper house of Parliament and the more publicly prominent 1951 Waterfront strike and the unprecedented snap election that it catalysed under Fraser's successor, the first National Party Prime Minister Sidney Holland.

Freyberg's successor and fellow Lieutenant-General was the Eton and Sandhurst educated Sir Willoughby Norrie, who had been Governor of South Australia since 1944. Despite humourlessly telling New Zealand audiences fresh from his tenure in Australia

\footnotetext{
${ }^{669}$ Letter from Peter Fraser to Mulholland, 7 November 1945, G48 Box 21 P/5(5), ANZ

${ }^{670}$ Bassett and King, Tomorrow Comes the Song - A Life of Peter Fraser, p 299
} 
that he was a Kiwi now and no longer 'Sir Wallaby Nirrie" ${ }^{671}$ he still struggled with Māori pronunciation and was helped by Prime Minister Holland to say "my-right-eye" when attempting the name Maraetai. ${ }^{672}$ Sir Willoughby's term 1952-57 was, as the chronicler of the invaluable history of the vice-regal office 'free of political controversy'. ${ }^{673}$ This is another way of saying that Norrie, like his immediate predecessor and most of his successors, kept to the New Zealand convention of constitutional non-intervention. The highlight of his term constitutionally, but more culturally was the Royal Visit of Elizabeth II in 1953-54, the first reigning monarch to visit the New Zealand islands. However, Holland was the local personality that attached himself visibly to the Royal personage, prompting the renowned candour of the Duke of Edinburgh to exclaim 'what, you again?' ${ }^{674}$, while Norrie correctly observed protocol and allowed the Sovereign he represented to be the focal point.

Holland was not as diligent on protocol and let slip with irreverence the 'efficient' reality and power of the Prime Minister over the 'dignified' mythical powers of a Governor-General as the startled British High Commissioner, Sir George Mallaby, observed.

At the state luncheon given in honour of the retiring Governor-General Sir Willoughby Norrie, he [Holland] included in his speech a remark on these lines: "I have, of course, sent a report to the Queen about you, Your Excellency, and I don't think you would be altogether displeased if you could see what I wrote." This piece of rather childish arrogance gave great offence. Who was $\mathrm{Mr}$ Holland to report on the Governor-General and how could he have the impertinence to imply that it was in his power to confer favours? ${ }^{675}$

Viscount Cobham came near the end of 1957 and had a wealth of ancestral connections to New Zealand. Cobham was faced at the end this thesis's period, but the beginning of his, with the potential of a hung parliament in 1957, which exercised the New Zealand political brain on parliamentary arithmetic to a degree not seen again till the MMP era. The new Governor-General enlisted the help of none other than Sir Ivor

\footnotetext{
${ }^{671}$ McLean, The Governors - New Zealand's Governors and Governors-General, p 263

${ }^{672}$ Sir John Marshall, Memoirs Volume One: 1912 to 1960, Auckland: Collins, 1983, p 111

${ }^{673}$ McLean, The Governors - New Zealand's Governors and Governors-General, p 263

${ }^{674}$ Bruce Brown, "Holyoake's Precursors" in Holyoake's Lieutenants, Margaret Clark (ed.), Palmerston North: Dunmore Press, 2003, p 14

${ }^{675}$ Sir George Mallaby, From My Level - Unwritten Minutes, London: Hutchinson, 1965, p 74
} 
Jennings on what to do in the small political arena of New Zealand if a government could not be formed. Suggestions included offering ministerial posts to the Opposition or as Sir Robert Menzies advised: 'tell Sid [Holland] to offer the Speakership to a member of the Opposition'. ${ }^{676}$ Jennings, mindful of the Byng example, told New Zealand's Governor-General that 'it is safer to take advice than to reject it' ${ }^{677}$ Lord Cobham was grateful for advice and hoped he would not 'make a bloomer' over the political situation. ${ }^{678}$ In the end the Governor-General was saved from having to make any arduous decisions since Labour came out of the 1957 election with a bare, but workable, majority and Government House could continue the convention of nonintervention.

Cobham, who had toured the country representing the M.C.C. in his youth, was fond, like many of his countrymen and class, of cricketing metaphors, telling a youthful Hastings audience that 'a Governor-General is a person rather like a wicket-keeper; he is definitely part of the game, but he is seldom noticed until he makes a mistake'. ${ }^{679}$ However, it would be more accurate to describe a New Zealand Governor-General's role as a keen observer and dedicated enthusiast of the political game, not a player or even an umpire though at least comforted with a premier seat and view from the Members' stand, a regular invitation to the after-match function and even a commemorative photo with themselves and the country's political first XI at the beginning of the parliamentary innings. The inability to activate or project the Governor-General's legitimate constitutional powers meant the incapacity and impotence to provide an effective form of executive horizontal accountability, which allowed the Prime Minister and Cabinet to have undisguised supremacy over the state.

\section{Prime Minister and Cabinet}

The Royal visit of the Queen and the Duke of Edinburgh to New Zealand in 1953-54 aroused a level of national fervour previously unknown for a public occasion and provides an example of New Zealand's early deference to the British Monarchy while at the same time demonstrating the shallowness of the Crown's political power. It is believed that three in every four New Zealanders saw their Queen and thus completed

\footnotetext{
${ }^{676}$ Letter from Lord Cobham to Sir Ivor Jennings, 2 July 1957, Jennings Papers, Miscellaneous C17.3, ICS125, ICS

${ }^{677}$ Jennings to Cobham, 2 November 1957, Jennings Papers, Miscellaneous C17.3, ICS125, ICS

${ }^{678}$ Cobham to Jennings, 25 October 1957, Jennings Papers, Miscellaneous C17.3, ICS125, ICS

${ }^{679}$ McLean, The Governors - New Zealand's Governors and Governors-General, pp 265-268
} 
the cultural compact with Britain discussed in the first chapter, an event described even today as the 'most elaborate and most whole-hearted occasion in New Zealand history'. ${ }^{680}$ Constitutionally the Queen would open Parliament on its centennial in 1954. The twenty-seven year old Queen told to the collective enchantment of her government and loyal opposition:

A hundred years ago, when the people of New Zealand gained for themselves the right of responsible self-government, it would have required a prophetic imagination to have foreseen the possibility of the present occasion. But in these hundred years New Zealand has grown to be a sovereign and mature State...

Prime Minister Holland replied with enthusiasm that he hoped the New Zealand legislature would 'prove worthy of our Queen' as all New Zealanders wanted to express in person 'their feelings of loyalty and devotion to their Sovereign, and their enthusiasm and love for Her'. New Zealand was a country, stirred Holland, 'patterned on that of Britain, the alternative to which is system that is foreign to our way of life'. The Leader of Her Majesty's Loyal Opposition, Walter Nash, concurred that 'we on this side of the House are of one mind with the Prime Minister in his remarks about he visit of Her Majesty the Queen' who 'is an example to us all, and who does more to maintain our system of democracy more than any man or woman can really understand'. Nash gushed that "we have had no threat of dictatorship in this country and there never will be so long as we have our form of government, and persons like Her Majesty, reigning in the way she does'. 681

All the Queen's New Zealand parliamentarians were in Nash's panegyric phrase “one mind" in praising the symbolic visit and participation of their monarch and also the 'dignified' Westminster system she represented. However, despite the no doubt genuine affection for the Queen, the fact was that the Queen reigns, but it is the Prime Minister who ruled New Zealand through delegated democracy in a way a British Prime Minister could not. The Queen was in her glamorous appearance and regal coronation robes the ceremonial part of the constitution that added allure and pomp, but the substance of power lay elsewhere. The Queen "an example to us all", for whom the

${ }^{680}$ Jock Phillips, Royal Summer - The Visit of Queen Elizabeth II and Prince Philip to New Zealand 1953-54, Wellington: Department of Internal Affairs, 1993, p 1 and p 8

${ }^{681}$ NZPD, Vol. 302, pp 2-6, 12 January 1954 
assembled politicians felt "love" and hoped to be "worthy of", had no ability to directly determine or initiate policy. The Queen was a powerful cultural symbol, but not a powerful institutional actor. The Monarch was relegated to the visible ceremonial and dull bureaucratic custom.

New Zealand's constitutional documents in true British Westminster fashion centred almost entirely on the Crown and did not trouble to mention or even name the office of Prime Minister or Cabinet the body that he headed. Despite their conspicuous absence it was the Prime Minister and Cabinet who exercised with complete confidence the full powers entrusted to the Crown, which was delegated to them to employ. Sir Kenneth Keith reflected after a quarter of a century of Queen Elizabeth's reign over the New Zealand Westminster system, which

has its Marquess of Queensbury rules, and public opinion as the referee. But ... the question whether New Zealand can continue to depend on the extent that it has on customary restraints and on the good sense and tolerance of those with the powers. Formal restraints should perhaps be more seriously considered than they were in the 1950s and 1960s. Very broad powers have been conferred on the government and while, as New Zealand's first Prime Minister [Henry Sewell in 1864] said, "All Governments intend to use arbitrary power with moderation", we might, like him, lack confidence in the strength of purpose of government to resist the temptation to use the power improperly in certain situations. ${ }^{62}$

\section{Prime Ministerial and Cabinet Power in and over New Zealand}

New Zealand is a country with a small population and parliament. In political terms up until the late sixties the House of Representatives had just eighty seats including the four reserved for Māori. With the full establishment of the two-party system in this 1947-57 era, which first witnessed the alternation of power between Labour and National, a government could be formed with less that fifty seats. Keith Jackson has calculated the compact and restricted nature of cabinet government in New Zealand. The British 'inner' Cabinet is around twenty, which is roughly the same size as New Zealand's Cabinet. However, the range and avenues of choice and scale of parliament is markedly different. In Britain the choice is 20:315 (average size of the majority party

${ }^{682}$ K. J. Keith, "Constitutional Change" in Thirteen Facets - Essays to Celebrate the Silver Jubilee of Queen Elizabeth the Second 1952-1977, Ian Wards (ed.), Wellington: Department of Internal Affairs, 1978, p 36 
in the House of Commons excluding those available for selection from the House of Lords) while in New Zealand it is approximately 20:45. ${ }^{683}$

There is undoubtedly an intimacy within the New Zealand political system not seen in other traditional Westminsters, which allows a greater personalisation of executive power, where the executive can be more than twenty-five per cent of the elected legislature. The compactness of the political executive and limited pool of actors to populate it lends credence to McLeay's words that 'New Zealand's political executive is essentially government by amateurs' since ministers are rarely experts in their portfolios or policy areas. ${ }^{684}$

Roderic Alley has argued that in the political context 'within a small, relatively intimate country, pragmatic adoption of unwritten constitutional rules has allowed a free rein to the executive. Unlike their Australian counterparts, New Zealand Prime Ministers have been unbothered by the uncertainties and restraints imposed by bicameralism and federalism' ${ }^{685}$ A more blunt assessment by Richard Mulgan, which adds tight party discipline and the first-past-the-post electoral to Alley's statement, utilises Hailsham's evocative phrase to identify New Zealand as the model of 'elective dictatorship'. ${ }^{68}$ According to Stephen Levine, New Zealand's parliamentary democracy is 'structurally very simple' due to the 'Westminster system in its New Zealand form' as 'a unitary state, a unicameral parliament [with] an unwritten constitution', which 'offered too few checks on executive power' ${ }^{687}$ All of these elements became especially evident within the 1947-57 period. The executive cosiness and compact political surroundings, along with a relatively minimal, but concentrated bureaucracy meant more things reached the Cabinet and Prime Minister than in most Westminster countries.

The modern functioning and systematic methodology of Cabinet began in these years through two crucial developments. At the beginning of the period the Cabinet Secretary

\footnotetext{
${ }^{683}$ The unelected Legislative Council was abolished in 1950 and even before its abolition few ministers in political history could claim membership of that chamber). Keith Jackson, "Cabinet and the Prime Minister" in Politics in New Zealand - A Reader, Stephen Levine (ed.), Sydney: George Allen \& Unwin, 1978, pp 63-64

${ }^{684}$ Elizabeth McLeay, "Cabinet" in New Zealand Government and Politics, $4^{\text {th }}$ edition, p 201

${ }^{685}$ Roderic Alley, "The Powers of the Prime Minister" in New Zealand Politics in Perspective, $3{ }^{\text {rd }}$ edition, Hyam Gold (ed.), Auckland: Longman Paul, 1992, p 174

${ }^{686}$ Richard Mulgan, "The Elective Dictatorship in New Zealand” in New Zealand Politics in Perspective, $3^{\text {rd }}$ edition, pp 513-531

${ }^{687}$ Stephen Levine, "Parliamentary Democracy in New Zealand", Parliamentary Affairs, Vol. 57, No. 3, 2004, p 646
} 
was for the first time in early 1948, over ninety years after the position was established, permitted to formally attend Cabinet by right and was instructed to keep a full record of Cabinet proceedings so 'that some check would now be kept on important decisions in Cabinet and, in particular, action on important matters when required'. Previously Prime Ministers or a senior minister noted decisions and officials were rarely in attendance for many years despite the long history of Cabinet. There is precious little official or archived material of the pre-1948 era since it was previously 'the custom for the Prime Minister to either take these records with him when he left office, or alternatively to have them destroyed or disposed of in some other way'. It had been common for papers to be seen as the personal property of ministers or burnt as for instance happened in 1935 when government papers of the past forty-four years were nihilistically incinerated. ${ }^{688}$ Secondly for the first time and at the end of this thesis's period, when a change of government occurred in 1957, the defeated National Government agreed to leave a complete set of cabinet papers to be held by the Cabinet Secretariat for the incoming Labour Government; this practice was thankfully followed by successive administrations. ${ }^{689}$

To indigenise Robert Chapman's description that New Zealand had 'fortress Cabinets' ${ }^{690}$ Cabinets were a political pa and citadel of executive power with the Prime Minister as chief or te ariki due to the jealous concentration and defence of power from any opponents or institutional intruders. ${ }^{691}$ McLeay asserts 'because Cabinet occupies central stage in the political system, the political actors who comprise it profoundly affect the perceived legitimacy of New Zealand parliamentary government'. ${ }^{692}$ And the premier political actor within the Cabinet is the Prime Minister, who holds real power due to the centrality, focus, patronage and decision-making capabilities of the position

\footnotetext{
${ }^{688}$ Note of Meeting, 29 January 1948 (Cabinet Secretary - Foss Shanahan), Cabinet Papers of the Labour Administration 1948-1949, AAFD 811 1A 1/1/1-1/7/1, Note by Cabinet Secretary, 15 September 1948, Cabinet Records 1948-57, AAFD 811 175G 1/9/1 Part 1, ANZ; Sinclair, Walter Nash, p 279 and Scott, The New Zealand Constitution, p 107 and see Marie Shroff, "The Role of the Secretary of the Cabinet The View from the Beehive", New Zealand Centre for Public Law, Occasional Paper No. 5, July 2001, pp 2-3

${ }^{689}$ Prime Minister Holyoake to Leader of the Opposition, Walter Nash, 11 December 1957 - 'I have to advise you that I have decided that a complete set of Cabinet Papers as held by the Cabinet Secretariat will be left in the Cabinet Office on the change of Government. Some of these papers will be of historic interest and all of them represent a record of Government decisions which have been made as acts of State during the term of office of the National Government. I feel that the proper course is to preserve them as State papers'. Cabinet Records 1948-57, AAFD 811 175G 1/9/1 Part 1, ANZ

${ }^{690}$ Robert Chapman, "Political Culture: The Purposes of Party and the Current Challenge" in New Zealand Politics in Perspective, $2^{\text {nd }}$ edition, Hyam Gold (ed.), Auckland: Longman Paul, 1990, pp 22-23 ${ }^{691}$ A pa is a traditional Māori fortification and te ariki is Māori for Paramount Chief or Lord.

${ }^{692}$ McLeay, "Cabinet" in New Zealand Government and Politics, $4^{\text {th }}$ edition, p 213
} 
and is the potential source of the personalist power of delegated democracy. In its faithfulness to British culture Prime Minister and Cabinet are 'creatures of convention' since even the Prime Minister's power to be chief adviser to the Governor-General is not stated in the Letters Patent. ${ }^{693}$ And yet the cemented New Zealand convention and interpretation of Westminster practice is that the Governor-General 'must follow the Prime Minister's advice, and not be without guidance'. ${ }^{694}$ The sheer reality is that the Prime Minister who commands the House of Representatives holds the immense powers invested in the Crown since they are solely the exclusive and responsible adviser to the Governor-General in the exercise of executive power.

The New Zealand Prime Minister heads the executive, approves the legislative programme, decides how many ministers will be inside and outside Cabinet, allocates portfolios to those ministers, sets the agenda for Cabinet, and, as the chair of both Cabinet and Caucus, is the final arbiter on all decisions. The Prime Minister decides who will chair cabinet committees, and usually personally chairs the important Policy and Strategy cabinet committees and the Honours and Appointments Committee, the later of which provides for considerable patronage powers. As well, Prime Ministers are ex-officio members of all cabinet committees. ${ }^{695}$

The above contemporary assessments of New Zealand Prime Ministers and Cabinets are based on past practices. However, modern accounts of prime ministerial and Cabinet dominance have generally neglected the authoritarian and confident use of executive power in the 1940s and 1950s, which saw two of New Zealand's most powerful Prime Ministers as well as a raft of radical constitutional and political change. The centrality of executive and prime ministerial power became activated and real in 1947-57 era when the modern two-party system became firmly established with the alternation of power allowing for the entrenchment of tight party disciplined governments to supplant parliament as an independent arbiter and any revival of the short lasting administrations of the colonial era; conforming and symptomatic of the traditional Westminster characteristic of executive dominance over the legislature.

\footnotetext{
${ }^{693}$ McLeay, The Cabinet \& Political Power in New Zealand, pp 17-18

${ }^{694}$ John Henderson, "Prime Minister" in New Zealand Government and Politics, $2^{\text {nd }}$ edition, Raymond Miller (ed.), Auckland: Oxford University Press, 2001, p 109

${ }^{695}$ Margaret Hayward, "Prime Minister: Power" in New Zealand Government and Politics, $4^{\text {th }}$ edition, $\mathrm{p}$ 225
} 
The shrewd leadership and dominance of Peter Fraser over policy, party, parliament and country provided an example for Sidney Holland to arbitrarily utilise and manipulate New Zealand's simplistic Westminster constitutional structure for political profit. Theirs was a telling example for their successors and a telling illustration of the political executive's powers over all other branches of state. Labour ended its first and longest hold of the Treasury benches in this time and then ushered in the first National administration. Both parties consciously or unconsciously conceded and delegated real power to their leaders when they gained office to enhance the "purity" of power of the political executive over other political actors and therefore further contribute towards the weak horizontal accountability of New Zealand.

\section{Fraser's Legacy and the First Years of Delegated Democracy 1947-49}

By 1947 Labour had been in power for twelve years, seven of which were under Peter Fraser. Fraser was the transitional figure from pre to post independence who was at the helm when New Zealand became an independent country in law that formalised his potential for delegated democracy power. As Beaglehole stated, books detailing New Zealand's involvement in the Second World War are invariably centred on Fraser and he speculated that 'a book about the Labour Government between 1945 and 1949 would have to be largely about Peter Fraser too: about the decline and fall of a great man, mortally weary, who saw control slipping away from him... where control had been one of the main sources of strength ... [but] still ... an adroit [and] masterly politician' ${ }^{696}$ Fraser had been worn out by the strains and responsibilities of war leadership, but his capacity for keeping power had not dimmed. ${ }^{697}$ Labour may have limped back in to office after the 1946 election, but there was still never any doubt that Fraser was in charge and with the all or nothing feature of the standard Westminster electoral system the Labour majority of four (helped by the four Māori seats) was more than enough even compelling Fraser to label it 'a clear and definite mandate'. This slender majority of the ageing Government was whittled down further as death and decay ravaged the Labour, especially front, benches giving the impression of a government 'living from day to day'. 698

\footnotetext{
${ }^{696}$ J. C. Beaglehole, "New Zealand Since the War", Landfall, Vol. 15, No. 2, June 1961, p 139

${ }^{697}$ For a brief but useful overview of Fraser's much esteemed war leadership see Ian Wards, "Peter Fraser - Warrior Prime Minister" in Peter Fraser - Master Politician, Margaret Clark (ed.), Palmerston North: Dunmore Press, 1998, pp 145-158

${ }^{698}$ Bassett and King, Tomorrow Comes the Song - A Life of Peter Fraser, pp 312-322
} 
However, though Labour had only two years left after the ratification of the Statute of Westminster and did not bestow any great legislative pearls as compared to the bounty of policy produced in its earlier terms, the impressive power of Peter Fraser remained and would be a substantial legacy not only to the Labour Party, but their opponents as well. Though somewhat unkind to describe the last years of the first Labour Government as 'rotting out of office' A. R. D. Fairburn considered Fraser a 'demagogue with a remarkable understanding of power politics' who was still in his last years 'the most intelligent and able politician in New Zealand history'. ${ }^{699}$

In an innovative analysis in the study of New Zealand political science, Simon Sheppard ranked the country's Prime Ministers. Of the thirty selected, Peter Fraser commanded second place beating his predecessor Savage in to third place and conceding the top spot to New Zealand's longest serving Head of Government Richard Seddon. ${ }^{700}$ Former minister and prime ministerial biographer Michael Bassett in his study of New Zealand's leadership 'give[s] the prize for New Zealand's greatest twentieth-century Prime Minister to Peter Fraser' ${ }^{701}$ Fraser's high and exalted status in New Zealand political history owes much to his reputation and conduct overseas especially as a war leader and Commonwealth elder. His not inconsiderable involvement with the establishment and purpose of the United Nations entitles him to be labelled by some as the 'only New Zealand leader with a plausible claim to be recognised as an international statesman'. ${ }^{702}$ Fraser was able to gain this international reputation and ability through his mastery of the domestic scene.

This highly intelligent and largely self-taught man was through his dour cunning determination able to concentrate power in his own hands through his ascendance and political longevity. Many shared Leicester Webb's analysis that 'Fraser liked power, fought hard to win it, and towards the finish clung desperately' and this complex man with 'a high moral sense' was 'capable of intolerant and arbitrary action when he was convinced that what he was doing was in the national interest or that those who opposed

\footnotetext{
${ }^{699}$ A. R. D. Fairburn, “Mr. Fraser's Way of Doing Things”, Here \& Now, No. 1, October 1949, pp 8-10

${ }^{700}$ Simon Sheppard, "Ranking New Zealand's Prime Ministers", Political Science, Vol. 50, No. 1, $\left(50^{\text {th }}\right.$ anniversary issue), July 1998, pp 72-89

${ }^{701}$ Michael Bassett, "The Essentials of Successful Leadership in Twentieth-Century New Zealand Politics”, Political Science, Vol. 51, No. 2, December 1999, p 119

${ }^{702}$ Former Public Servant and Diplomatic Historian Malcolm Templeton cited in Bassett, "The Essentials of Successful Leadership in Twentieth-Century New Zealand Politics”, p 118.
} 
him were acting from bad motives'. ${ }^{703}$ He worked extremely hard as politics was his life and had a 'perverse' expectation for his officials to share these demanding traits. ${ }^{704}$ He was full of paradox, as Leslie Hobbs recounted -

Fraser was a complex man. A humanitarian who did a tremendous amount for the poor and the sick, he was at the same time ruthless, even unscrupulous, in securing his political aims. He was an intriguer, a shameless user of other people, and at the same time a zealous trustee of the social betterment ambitions of the most liberal spirits in his party. ${ }^{705}$

Whatever his aims it can be agreed that Fraser was a master politician who was correctly viewed as commanding the New Zealand political scene while Prime Minister. In Cabinet, with the obvious exception of his loyal deputy and eventual successor, Walter Nash, 'he tended to ride roughshod over them'. As Sir Alister McIntosh recalled he himself felt more 'a glorified Private Secretary than the Permanent Head' and all in the Parliament Buildings knew that 'Fraser did not like to delegate, especially to his officials. His Cabinet colleagues, too, knew better than to act on any important question without his knowledge or authority', showing the lack of horizontal accountability on the Prime Minister. ${ }^{706}$ Cabinet, party and official colleagues remember a Prime Minister who could be 'ruthless, calculating, cynical and insensitive and often insulting when dealing with others' who was 'vindictive, bad tempered and sadistic bully', while one former minister thought 'Machiavelli had nothing on him' ${ }^{707}$ Fraser was Minister of Police throughout Labour's fourteen years, with his unique powers of knowing the activities of all, which fuelled the suspicion of clandestine information networks and even his own side believed he was not 'averse to using police information as well as other sources to keep tabs on supporters of doubtful loyalty' ${ }^{708}$

\footnotetext{
${ }^{703}$ Leicester Webb, "Leadership in the Labour Party”, Political Science, Vol. 5, No. 2, September 1953, p 46

${ }^{704}$ See for example the late night demands on senior officials in McIntosh to Berendsen, 23 April 1947 in Undiplomatic Dialogue - Letters Between Carl Berendsen \& Alister McIntosh 1943-1952, p 123 and McIntosh to George Laking, August 1949 in Unofficial Channels - Letters Between Alister McIntosh and Foss Shanahan, George Laking and Frank Corner 1946-1966, Ian McGibbon (ed.), Wellington: Victoria University Press, 1999, p 70

${ }^{705}$ Leslie Hobbs, The Thirty-Year Wonders, Christchurch: Whitcombe and Tombs, 1967, p 42

${ }^{706}$ Sir Alister McIntosh, "Working with Peter Fraser in Wartime" in Peter Fraser-Master Politician, pp 160-167

${ }^{707}$ Gustafson, From the Cradle to the Grave - A Biography of Michael Joseph Savage, pp 270-271

${ }^{708}$ Ormond Wilson, An Outsider Looks Back - Reflections on Experience, Wellington: Port Nicholson Press, 1982, p 144
} 
Caucus was no different, where he was 'undoubted master' and was in last years a 'stern and scolding party disciplinarian', treating backbenchers as them as a headmaster would over schoolboys often with 'a rod of iron' and even the Opposition leaders warned their members to use 'commonsense' and avoid a 'head on clash with the Old Man'. 709 Though outwardly 'allowing the letter and trappings of caucus democracy, Fraser, with cunning sagacity, was in practice an autocrat who largely destroyed its spirit ${ }^{710}$ so that they became 'tame affairs', where backbenchers were subject to 'abusive' comments if they erred from the expectation 'to be seen but not heard'. ${ }^{711}$ Fraser's insistence on seeing everything and deciding everything was infamous, showing his personalist tendencies. Fraser the political carnivore was even specifically requested at a 1948 Cabinet meeting to directly endorse the assignment of fountain pens to his ministerial colleagues and civil servants. ${ }^{712}$

Fraser was able to act the way he did, in these last years of 1947-49 especially, because of his supremacy over the New Zealand executive, which offered few effective or volunteering forms of horizontal accountability. Fraser's innate authority and conspicuous political skill and ability over party and parliament meant that he was in a position unchallengeable as Prime Minister until the citizens could pass judgment at election time. Through his actions and by his abilities he generally proved himself worthy of his powers even according to his detractors. In the pursuit of power even Fraser put forward a referendum on conscription to 'sideline the government's wider difficulties' despite his party's and his own background attempting to curry a patriotic favour in the Cold War climate with the electorate and to foil the looming spectre of National triumph at the 1949 elections. ${ }^{713}$

Fraser and his exhausted and decomposing government could not escape defeat in the face of National's vigour and fresh appeal. Fraser, like many who hold such power, did not last long after losing power - though he stayed on and would die as Leader of the Opposition in December 1950. The King pronounced on Fraser's death that 'His

\footnotetext{
${ }^{709}$ Bassett and King, Tomorrow Comes the Song - A Life of Peter Fraser, p 318 and Hobbs, The ThirtyYear Wonders, pp 49-51

${ }^{710}$ Gustafson, From the Cradle to the Grave - A Biography of Michael Joseph Savage, p 270

${ }^{711}$ Wilson, An Outsider Looks Back - Reflections on Experience, pp 143-149

${ }^{712}$ Cabinet Minutes, 3 September 1948, Cabinet Papers of the Labour Administration 1948-1949 AAFD 811 1A 1/1/1-1/7/1, ANZ

${ }^{713}$ See David Grant, "Anti-Conscription, Conscription and the Referendum” in Peter Fraser - Master Politician, pp 131-144 and Bassett and King, Tomorrow Comes the Song - A Life of Peter Fraser, p 337339
} 
services to New Zealand as her Prime Minister during a critical period of her history and in the councils of the British Commonwealth will long be remembered with gratitude'. ${ }^{714}$ The new National Cabinet respectfully adjourned on receipt of the news of the death of their old adversary and Sidney Holland no doubt contemplated the same thoughts as the King, but for himself perhaps also considered Fraser's delegated democracy legacy of concentrated executive power readily available to a New Zealand Prime Minister. ${ }^{715}$ Whether he did or not, Prime Minister Holland actively pursued a doctrine of wielding immense political power as the successor to the Fraser legacy.

\section{The Holland Hegemony}

Sidney Holland is one of the most neglected New Zealand Prime Ministers, despite being the first National leader to become Prime Minister as well as presiding over some of the most striking constitutional events during almost eight years at the nation's helm. Though admittedly, there are few credible political biographies of New Zealand Prime Ministers, the reason for Holland's almost complete absence could be to do with the portrait of him as an uninstructed and undistinguished mind not given to intellectual diversions and a rather imperfect grasp of urbanity with a limited outlook that did not stray beyond the Canterbury plains. A contemporary account brazenly called him a 'cockily pugnacious figure' who was 'almost Neanderthally[sic] slow'. 716 Regardless of the critiques Holland must be more prominently housed in the gallery of major New Zealand politicians since despite what the critics cry he did by his actions and coarse political dexterity compel since he left a definitive mark on the political canvas, whatever the merit of his artistry. "Gentleman Jack" Marshall who served under him initially under the rather unique title "Minister Assisting the Prime Minister" had a more measured drawing of his former master: 'He was an ordinary man with extraordinary qualities. He was not a humble man, he had an air of confidence, but there was no arrogance in him. He understood the average man and his needs, his hopes and his aspirations, in a way that made him a man of the people'. ${ }^{717}$ While former long serving civil servant Bruce Brown adds to this impression by arguing that Holland 'was a shrewd judge of the opinions and prejudices of the average New Zealander of this time,

\footnotetext{
${ }^{714}$ Telegram from the King to Government House, Wellington, 12 December 1950, Biography - Peter Fraser, ABHS 950 W4627 Box 1100 32/8/8 Part 1, ANZ

${ }^{715}$ Cabinet Minutes, CM (50) 86, 12 December 1950, Cabinet Minutes - Prime Minister's Copies December 1949-June 1950, AAFD 808 1A (49) 1-(50) 39, ANZ

${ }^{716}$ Robert Blake, "Mr Holland - The Energetic Accident", Here \& Now, No. 1, October 1949, p 13

${ }^{717}$ Marshall, Memoirs Volume One: 1912 to 1960, p 140
} 
probably because he shared them. He was no intellectual but had a sharp, shrewd, basically provincial cast of mind'. ${ }^{718}$

Holland did, however, possess the acknowledged skill of political and personal buoyancy and energy, which put him in favourable contrast to the atrophying previous administration. ${ }^{719}$ He was 'a practical man of action, not given to contemplation' who was able to identify with the electors and they with him. ${ }^{720}$ His victory in 1949, for he was largely responsible for the revival of the National Party, had a 'tame inevitability', which Holland's minimalism and efficiency had much to with.

Perhaps Sidney Holland was such an effective leader because of his basic simplicity. To him the slogans which more complex men will use with a certain interior reserve and scepticism were perhaps heart-felt realities, as heart-felt as the simple enjoyment of power. The self-made man, private enterprise, the Empire (no Commonwealth for him!), the Old Country, the Queen: he like his party, may well have been almost wholly inspired by these uncomplicated generalities. $^{721}$

Holland's simple and energetic attitude extended to his views on the constitution. The former Canterbury businessman was thoroughly deferential to the Monarchy and British culture as discussed above. Holland no doubt wrote with sincerity to George VI when he wished on behalf of the new government that he 'beg respectfully to tender to Your Majesty most loyal greetings, to give an assurance of unswerving devotion to Your Majesty's Throne and Person' and (using the now politically incorrect title of Dominion $^{722}$ ) promised 'to affirm the determination of Your Majesty's Government in New Zealand to devote themselves wholeheartedly to the administration of the Dominion and the advancement of the welfare of Your Majesty's subjects therein'. ${ }^{723}$

At international conferences he would speak 'without subtlety or finesse' to express the 'uppermost feelings in his head loyalty to the U.K...' a position that often embarrassed

\footnotetext{
${ }^{718}$ Brown, "Holyoake's Precursors", p 14

${ }^{719}$ National Party biography on Rt. Hon. S.G. Holland, P.C., C.H., undated, in Sir Sidney Holland Papers, MS 1624-043/5, ATL

${ }^{720}$ Marshall, Memoirs Volume One: 1912 to $1960, \mathrm{p} 140$

${ }^{721}$ W. H. Oliver, "Sir Sidney Holland", Comment, Vol. 3, No. 1, Spring 1961, pp 5-6

${ }^{722}$ McIntyre, Dominion of New Zealand: Statesmen and Status 1907-1945, pp 172-173

${ }^{723}$ Executive Council meeting, 13 December 1949, Change of Government 1949, AAFD 811 W4198/38 48/9/1, ANZ
} 
his Commonwealth colleagues. ${ }^{724}$ However, as has been argued above, Holland though culturally deferential to the Monarchy and British did not see any need to be so deferential to Westminster axioms. As will be analysed in detail in the following chapter one of the first actions of this conservative administration was the abolition of the Legislative Council in 1950-51. The Prime Minister accomplished the end of New Zealand's upper house with negligible thought or consultation, but with considerable vigour and cunning. Holland's path dependent action changed forever the complexion of Parliament, eradicating another, albeit weak, check on prime ministerial power and going against the theory and practice of Westminster parliamentary government, which almost without exception contained second chambers at the centre.

Holland's abolition of the Legislative Council was not the only rapid and vigorous use of his constitutional powers inherited from Fraser. The new Prime Minister had even more power concentrated in his hands than his commanding predecessor. Holland was in command of a party which delegated more power and freedom to its leader than Labour and which had a very comfortable majority in the House of Representatives. The new Cabinet was bereft of ministerial experience except for a few, including Holland, who had brief and unsuccessful membership of the constrained War Administration, which lasted only a few months in 1942. Unlike Fraser the new Prime Minister did not take on External Affairs which went to Doidge, despite McIntosh's 'fears'. Doidge also took on tourism, which was more in keeping with the new minister's talents according to senior civil servants. ${ }^{725}$

As in Britain the other key ministry second only to the premiership is the Finance Ministry. Unlike Britain, where convention would debar such personalist concentration, the New Zealand Prime Minister combined these great offices of state and thus gave himself massive power over the country well before his similarly powerful successor Muldoon did the same; they both incidentally also shared a love of flowers that showed a rare delicate side seldom in evidence with their normally aggressive political machinations. ${ }^{726}$ Holland, the first leader of a National Government who held the post

\footnotetext{
${ }^{724}$ Mallaby, From My Level - Unwritten Minutes, p 146

${ }^{725}$ McIntosh to Berendsen, 10 December 1949 in Undiplomatic Dialogue - Letters Between Carl Berendsen \& Alister McIntosh 1943-1952, p 192

${ }^{726}$ Gustafson, The First 50 Years - A History of the National Party, p 40 and p 56. Another example is George Forbes who had also briefly held both offices.
} 
until after the 1954 election established his political power over his inexperienced Cabinet with his direction and control by holding these two towering posts. ${ }^{727}$

This was especially important in micro-executive polity of New Zealand when even the repair of the swimming bath at Waitaki Girls' High School required Cabinet approval. ${ }^{728}$ Even Fraser did not have such policy clout as Holland since he had to defer to the experience and position of Nash who held the finance post for almost all of Labour's fourteen previous years in office. Holland had no rivals and was surrounded by subordinates and not equals, though in his last years he would later face the impatience of the Deputy Prime Minister Keith Holyoake. ${ }^{729}$ As the history of the National Party stresses due to Holland's visibility and direct influence, with his seventeen years as party leader, he was as Prime Minister 'assertive in getting his own way' and 'with justification was regarded by some inside and outside the National Party as a tough, decisive, even dogmatic autocrat. Certainly Holland dominated caucus and Cabinet'. 730

\section{Strike and Snap 1951}

Holland was able to gain immense power constitutionally and politically with one of the most controversial episodes in modern New Zealand history: the 1951 Waterfront Strike and snap election that directly followed. Despite an aversion to reading books, Holland was a skilful politician fully capable of utilising the vast powers available to a New Westminster Prime Minister, especially in an executive system as "pure" and potentially dictatorial as New Zealand's. The formidable industrial dispute that engulfed the country erupted in February 1951 after months of simmering tension. It is not within the scope or purpose of this thesis to examine in detail the Waterfront Strike except from the constitutional angle as opposed to the prominent social slant.

\footnotetext{
${ }^{727}$ After giving up the Finance portfolio in 1954 Holland, perhaps with an eye to his predecessor, became Police Minister until his retirement in 1957.

${ }^{728}$ Cabinet Minutes, 31 July 1950 [CM (50) 52], Cabinet Minutes - Prime Minister's Copies June December 1950, AAFD 808 2B (50) 40-88, ANZ

${ }^{729}$ McIntosh confided soon after National came to power that the new Cabinet 'appears weaker than was expected' describing some of the ministers as 'just passengers' and being 'so extraordinarily weak and naïve as to hopeless', even Holyoake was seen a 'hollow shell' and 'as to Mr Holland himself, even my incredible indiscretion balks at this stage and I will not commit myself to paper'. McIntosh to Berendsen, 1 February 1950 in Undiplomatic Dialogue - Letters Between Carl Berendsen \& Alister McIntosh 19431952, p 207

${ }^{730}$ Gustafson, The First 50 Years - A History of the National Party, p 62
} 
The last years of the Labour Government were faced with vehement strike action, which was proving highly disruptive to the country's export driven economy. The new National Government initially endeavoured to settle with the infamous Federation of Labour strongman Fintan Patrick Walsh, but had less success with the militant and leftwing orientated Trade Union Congress, which was dominated by the Waterside Workers' Union known as 'Wharfies' or 'Watersiders' led by Walsh's great rival the formidable Harold 'Jock' Barnes. The crisis flared in February 1951 when the shipowners refused the fifteen per cent wage rise demanded by the Watersiders, while the Watersiders refused arbitration and refused to go back to work until their demands were met, prompting a lockout; their places later taken by servicemen. The ports became stricken with confrontation that threatened the economic well-being of the country and the effectiveness of Holland. The Government and many in the country perceived the industrial dispute as a challenge to their constitutional powers to govern and were quick to articulate that the Watersiders were supported by Communist dictums, an argument that gained unfortunate credence due to the Cold War fever. ${ }^{731}$

Rising inflation and disgruntled farmers compelled the man who held the Prime Ministership and Finance portfolio to act. Even before February the Government had prepared legislation to deal with the crisis. In September 1950 the Cabinet, with the assistance and attendance of the Legal Draftsman, prepared Emergency Regulations 'empowering the Government to declare the waterfront strike a "declared strike", authorising the suspension of the Waterfront Industry Award, empowering the Services to assist in such manner as they may determine in connection with the strike, providing for the sequestration of Union funds and for the appointment of a receiver, imposing restrictions on publication of information, display posters, etc., authorising action to deal with picketing, and prohibiting contributions to either the Waterside Workers' Union or to members of that Union' unless the watersiders returned to work at all ports, though these were not activated in their entirety till the 21 February 1951 State of Emergency. ${ }^{732}$

\footnotetext{
${ }^{731}$ For greater detail on the Waterfront Strike's unions see Michael Bassett, Confrontation '51 - The 1951 Waterfront Dispute, Wellington: A. H. \& A. W. Reed, 1972, Sinclair, Walter Nash, pp 282-283 and Herbert Roth, Trade Unions in New Zealand Past and Present, Wellington: Reed Education, 1973 ${ }^{732}$ Cabinet Minutes, 19 September 1950 [CM (50) 65], Cabinet Minutes - Prime Minister's Copies June December 1950, AAFD 808 2B (50) 40-88, ANZ and Bassett, Confrontation '51 - The 1951 Waterfront Dispute, pp 57-84
} 
The Government, which had accused its predecessor of using wartime powers in peacetime now themselves utilised the draconian Public Safety Conservation Act 1932, which had been brought to statute by depression era disturbances. The Act gave power to the Government through the Governor-General to declare a State of Emergency if public safety was 'imperilled' by disorder and gave the fantastic power to make any regulations by Order in Council including suspending 'the right of trial by jury' and 'any existing Acts of Parliament'; even still Cabinet wondered if the 1932 Act was 'altogether adequate' to deal with the unrest. ${ }^{733}$ On meeting the Prime Minister the unionists thought the regulations were 'fascist in origin and not in keeping with New Zealand traditions' and blamed Holland personally as the 'man responsible for the introduction of these regulations', who they believed had 'politically committed suicide, or will commit suicide if the regulations continue'. The Watersiders promised to do everything their power 'to combat the regulations'. ${ }^{734}$ Holland did not sympathise and the man of action acted with velocity. The Waterside Workers' Union was deregistered and its funds confiscated, but that was not all. Belich lists just some of the powers actually (not just theoretically) used -

Free speech was restricted; personal mail was opened; such actions as giving food to strikers' children were banned; the watersiders were falsely accused of being communist-inspired "traitors"; and anti-communist hysteria was deliberately encouraged. In an almost hysterical national radio broadcast, Holland made his claim that "a very determined effort has been made to overthrow orderly government by force". ${ }^{735}$

Beaglehole was not surprised by Holland's reactions since his Government's 'naïve brutality' for power could be explained by 'how famished for power' they were with 'an innocency of experience'. ${ }^{736}$ However, Holland was far from naïve in his pursuit for power and readiness to exploit legislation and centralised power. The Prime Minister's shrewdness allowed him to satisfy his political wants of destroying the Watersiders and increasing his power by tweaking and twisting sleepy Westminster conventions. The

\footnotetext{
${ }^{733}$ Bassett, Confrontation '51 - The 1951 Waterfront Dispute, p 83 and Cabinet Minutes, 19 September 1950 [CM (50) 65], Cabinet Minutes - Prime Minister's Copies June - December 1950 AAFD 808 2B (50) 40-88, ANZ

${ }^{734}$ Transcript of Trades Union Congress and New Zealand Waterside Workers' Union Deputation to the Prime Minister on 27 February 1951 in Holland Papers, MS 1624-103/6, ATL

${ }^{735}$ Belich, Paradise Reforged - A History of the New Zealanders From the 1880s to the Year 2000, p 301

${ }^{736}$ Beaglehole, "New Zealand Since the War", p 140
} 
ambiguities of Westminster power restrained only by gentlemanly conventions were ripe to exploit the virtual redundancy of horizontal accountability in New Zealand to deal with the problem facing any personalist 'elected dictatorship' - the vertical accountability to the electorate - by creating a crisis and electoral opportunity that would subvert the normal process of electoral accountability.

The Parliamentary Opposition was ineffective in the face of the Government's overt use of power. The aged Walter Nash had only just taken over the leadership of the Labour Party and in the hysteria Holland and the pro-government media generated he was attacked as an appeaser when he pronounced to a large crowd that 'we are not for the waterside workers, and we are not against them', which his biographer believes dogged him for the rest of his life and which he was never allowed to forget. Nash's attempt to calm the situation made him look as if he was committing 'treason'. ${ }^{737}$ Labour was hamstrung not only by their union connections and denigration in the media, but also in their inability to persuade the Prime Minister to allow Parliament to meet so they could debate in the national legislature the conduct of the Government and the crisis in the country, showing the constitutional inability of the Opposition to hold the Government to account over executive actions. As Bassett argues the use of such power without the necessity of Parliament was extraordinary:

Nash was painfully aware of the disadvantages under which the Labour Party was operating, hence the reason for his frequent requests that Parliament be assembled. In most countries where provisions existed for taking of emergency powers it was mandatory that Parliament be summoned, so that government actions could be subjected to careful public scrutiny. No such requirement existed in the Public Safety Conservation Act 1932, so Holland continued to refuse Nash's requests, thereby depriving the Labour Party of its most effective public forum. In fact, Parliament did not meet until 26 June 1951, which was almost the latest possible date in the year which it could assemble. ${ }^{738}$

Holland with his strong-arm tactics was defeating the unions by suffocating them through the emergency powers and media hype. Holland, known by his detractors as

\footnotetext{
${ }^{737}$ Sinclair, Walter Nash, p 285

${ }^{738}$ Nash's Labour Government passed the Public Safety Conservation Amendment Act 1960, which required Parliament to be called within seven days of the declaration of a State of Emergency. Bassett, Confrontation '51 - The 1951 Waterfront Dispute, p 192 and Bassett's footnote 119.
} 
the "Senator for Fendalton", was using McCarthy Cold War tactics in portraying the left leaning unions as traitors in that uneasy immediate post-war period. The unwitting Nash did not know it but Holland was calculating how to increase his power in this climate of panic and appeal to the country to reap full advantage of the crisis with a snap election. Marshall was asked by Holland to secretly investigate his options in June 1951.

[T] he Prime Minister asked me, in the strictest confidence, to advise him on the constitutional position, in advising the Governor-General to dissolve Parliament for the purpose of holding a general election. I got the books from the parliamentary library, personally and without reference to the librarian ... Our secret plans had not been detected. On the contrary, on 4 July Mr Nash moved a motion of no confidence and challenged us to go the country on the strike issue. I had briefed the Prime Minister on the procedure, and advised him that the Governor-General would, undoubtedly, accept his advice if he sought a dissolution of Parliament. ${ }^{739}$

Holland was delighted and accepted Nash's unsuspecting challenge. Holland called on Freyberg a little over a week later who received the news 'in considerable shock' and 'without warning' due to the increasing political remoteness of Government House. Holland and Marshall had obviously consulted the Governor-General's powers and precedents without personally bothering the man who held the office. Freyberg would be no Byng $^{740}$ and readily provided his assent without condition or clamour to the dissolution request despite Parliament having a year and a half to run; just as he had allowed the Emergency Regulations to be carried out in his name. ${ }^{741}$

Perhaps Sir Bernard's job was made easier since just a month earlier he had been raised to the peerage as Baron Freyberg of Wellington personally endorsed to Attlee and the King by a grateful Holland ${ }^{742}$, despite most peerages coming at the end of a Governor-

\footnotetext{
${ }^{739}$ Marshall, Memoirs Volume One: 1912 to 1960, p 174

${ }^{740}$ Lord Byng was Governor-General of Canada during the 1926 constitutional crisis when he denied Prime Minister Mackenzie King's request for dissolution.

${ }^{741}$ For the possibility of an alternative view see Antony Wood, "New Zealand" in Butler and Low (eds.), Sovereigns and Surrogates - Constitutional Heads of State in the Commonwealth, p 127 and 141

${ }^{742}$ Paul Freyberg, Bernard Freyberg V.C. - Soldier of Two Nations, London: Hodder \& Stoughton, 1991, pp 545-547
} 
General's term. ${ }^{743}$ Therefore despite having the secure confidence of the House of Representatives on the 11 July 1951, the day the Watersiders gave in, Parliament was dissolved prematurely for the first time since 1887, the Government appealing to the country with the vivid slogan "Who is going to govern the country". ${ }^{744}$ In a political environment of grateful public, defeated unionists, ineffective Opposition and a satisfied Governor-General, Sidney Holland knew the answer.

National increased its majority to twenty holding fifty of the eighty seats and winning fifty-four per cent of the votes cast, a record not beaten till the 1990 election by the Bolger Government. The country had not asked for, 'though it was quite pleased to sanction, the stroke of cunning that bolstered the government with the premature but of course successful 1951 election'. Holland's gamble had paid off and now more easily than ever could rule with a "rod of iron'. ${ }^{745}$ Holland would go on to win the 1954 election and reluctantly retired near the end of 1957, though consoled with a G.C.B. and a place in Cabinet as Minister without Portfolio in Keith Holyoake's brief first administration. Holland left an indelible legacy by exercising prime ministerial power, with such dextrous skill that it overshadowed his lack of sophistication. Holland aggravated the partisan card and in so doing sowed the two-party system and demonstrated the full powers available to a New Zealand Prime Minister. However, his most audacious exercise of power in constitutional terms was not his critical handling of the Waterfront Strike and the following snap election of which there are comparable examples throughout the Westminsters, but instead was the abolition of the Legislative Council.

\footnotetext{
${ }^{743}$ For example Freyberg's immediate predecessor (Newall) and successor (Norrie) became peers only after their return to England.

${ }^{744}$ Martin, The House - New Zealand's House of Representatives 1854-2004, p 241

745 Oliver, "Sir Sidney Holland", p 5
} 


\section{Unicameralism: The Strange Eventful Death of the Legislative Council}

The 'commonplace' and seemingly 'uninteresting' passing of the Statute of Westminster in 1947 was in fact a 'critical juncture' in path dependent theory that ushered in a new era of 'triggering events' that included substantial constitutional change and the rise of personalist power. ${ }^{746}$ Though not generally appreciated the late 1940s and 1950s was an era that had critical path dependent features where significant events and actions happened that would shape the New Zealand executive polity for decades. The opportunity and subsequent abolition of the Legislative Council is a prime example of a personalist and constitutional action that demonstrated the power of the executive.

The Legislative Council like the other parliamentary institutions owed its existence to the imperial instruction that was the New Zealand Constitution Act 1852. New Zealand like other settler colonies was determined to transplant British parliamentary institutions to their nascent polity. Crown, Lords and Commons would find home in New Zealand though not as they knew it in Britain. Like many British colonial legislatures the Legislative Council that came to life in 1854 suffered the delusional expectation of replicating the hereditary and ancient House of Lords. Not that the hereditary principle could be transposed to the settler colonies ${ }^{747}$, but the principle of having a permanent upper chamber that could and would independently defend the tenets of the constitution and British traditions, and be less swayed by the populist pressures of the elected lower chamber was clearly in mind and aimed for. Instead of peers New Zealand would have life appointments to the Legislative Council appointed by the Crown on advice of the Prime Minister to provide permanence compared to the changing membership of the House of Representatives and Government House.

\footnotetext{
${ }^{746}$ Mahoney, "Path Dependence in Historical Sociology", pp 512-513 and Pierson, "Increasing Returns, Path Dependence, and the Study of Politics", p 263

${ }^{747}$ Although Australia and Canada did toy with ideas in the nineteenth century of creating a colonial peerage or baronetcies to populate their upper houses. See David Cannadine, Ornamentalism - How the British saw their Empire, London: Penguin, 2002, p 144
} 
However, from the onset the upper chamber became more a convenient storage house of political patronage than a place of independent views, which was extended further when in 1862 all limits on its membership were removed, allowing the elected executive even more power to impose its views upstairs further eroding the independence and effectiveness of bicameralism as a check on the executive. Thirty years later in 1892 this political fact was further emphasised when life appointments were abolished and replaced by seven-year terms, which gave an ability to reward party figures (or exile them) by keeping Councillors even more ensnared with the power to reappoint or allow their membership to lapse. ${ }^{748}$ The House's powers were surrounded, like the House of Lords, by ambiguity and grandiose false expectation. As Keith Jackson states the Legislative Council's constitutional position was from the very beginning devoid of institutional certainty:

In the founding Constitution for New Zealand, the powers of the Legislative Council were left studiously vague. Presumably, however, these would include the right to initiate legislation (both public or private), to revise and reject legislation previously adopted by the lower house, and to initiate parliamentary inquiries. Although there were no formal limits to these upper chamber powers, it was assumed that British practices would prevail.... ${ }^{749}$

Bicameralism was long held to be the accepted governing practice in the Empire and later the Commonwealth and beyond. ${ }^{750}$ However, the Legislative Council had long ceased to be an effective part of the New Zealand Parliament. Attempts at reform had floundered, including a proposal for an elected upper house due to apathy and political disinclination. ${ }^{751}$ As Leslie Lipson remarked on the forgotten chamber 'shadows cannot command respect'. ${ }^{752}$ Like the majestically gilded chamber of the House of Lords the august and imposing surroundings of the Legislative Council belied its impotence against the dominance that resided in the rough forum that is the House of

\footnotetext{
${ }^{748}$ For a detailed analysis of the Legislative Council in the colonial era see A. H. McLintock and G. A. Wood, The Upper House in Colonial New Zealand, Wellington: New Zealand Government Printer, 1987 ${ }^{749}$ Keith Jackson, "The Abolition of the New Zealand Upper House of Parliament" in Two Into One The Politics and Processes of National Legislative Cameral Change, Lawrence D. Longley and David M. Olson (eds.), Boulder: Westview Press, 1991, p 47

${ }^{750}$ Meg Russell, Reforming the House of Lords - Lessons from Overseas, Oxford: Oxford University Press, 2000, pp 19-22

${ }^{751}$ For instance see the proposals in Report of the Select Committee upon the Constitution of the Legislative Council together with minutes of proceedings in Appendices to the Journals of the Legislative Council, 1913 (commonly known as Sir Francis Bell's Act)

${ }^{752}$ Leslie Lipson, The Politics of Equality, Chicago: University of Chicago Press, 1948, pp 361-362
} 
Representatives. New Zealand, a state that claimed to be the loyalist of the loyal to Britain did not feel the need to copy Imperial Westminster or even the New Westminsters by maintaining the traditional Westminster parliamentary trinity of the crown and two houses of parliament. New Zealand's abolition of its upper house was a critical juncture that was almost unprecedented in the Westminsters ${ }^{753}$ since it ushered in without thought or pause unicameralism that signalled and accentuated with path dependent volume the dominance of executive.

\section{An Expedient Institutional Target for Party Games}

Since at least the time of Sir George Grey there had been calls to abolish the Legislative Council with its unpalatable elements of political "nomineeism" that destabilised any institutional independence and publicised cost for a chamber that did not seem to function even as a revising chamber. In the period 1936 to 1950 the Council only amended just over nine per cent of bills from the lower house and could not claim a single bill that originated in its chamber becoming an Act. ${ }^{754}$ The fact was that by the 1940s the limited efficacy of the Legislative Council made it a dumping ground for party supporters rather than a vigorous upholder or contributor of parliamentary government. The Labour Party, since its inception in 1916, and been committed to abolition of a Council that 'served as a haven for political derelicts'. A sympathetic newspaper The New Zealand Worker stated the Labour position in 1934:

From a Labour standpoint, the Upper House is an utter superfluity, and no true democrat could approve of the existence of a legislative chamber which is not responsible to the electors for its actions, and at the same time is empowered to tamper with, mutilate and even reject legislation which the elected representatives of the people passed ... With the advent of a Labour Government, the people of New Zealand would not have long to wait for the complete abolition of this rankly obsolescent institution whose exit from the political stage is much overdue. $^{755}$

However, once in office Labour just a year later after the above article was written, did as their predecessors and commandeered the Council as a place of party patronage. In

\footnotetext{
${ }^{753}$ An exception, though not at the national level, is the abolition of the Australian State of Queensland's upper house in 1922.

${ }^{754}$ W. K. Jackson, The New Zealand Legislative Council - A Study of the Establishment, Failure and Abolition of an Upper House, Dunedin: University of Otago Press, 1972, pp 238-239

${ }^{755}$ The New Zealand Worker, 27 June 1934 (Contained in the Marshall papers, ATL)
} 
fact their diligence with "nomineeism" was more pronounced than earlier governments since they held office continuously for fourteen years 1935-49. National Party policy papers show that the Opposition thought 'the Labour Party came to regard the institution as a superannuation scheme for Party supporters, and during its term of office, it packed the Chamber with Labour supporters. The Council lost its character as an impartial body whose purpose was to consider legislation and to improve it where possible. Bluntly, it became a useless appendage'. ${ }^{756}$ Holland as Leader of the Opposition since 1940 was very fond of quoting Savage, Fraser and Nash that Labour had previously supported abolition. ${ }^{757}$ The credibility and impartiality of the Legislative Council was suspect according to Holland when in the late 1940s of the 37 members 22 were miners, watersiders, Union Secretaries or ex-officials of the Labour Party and nine defeated Labour MPs. ${ }^{758}$

Costing over $£ 30,000$ a year and an easy target to strike at and embarrass an elderly government, Holland cleverly used the Legislative Council as a convenient example to portray to the electorate Labour's profligacy, inefficiency and bias. Labour had only just returned to the Treasury Benches with a four seat majority in the 1946 election, even after the abolition of the "Country Quota". Holland and his party naturally greedy for power saw what would normally be a dry constitutional topic and turned it into one of high party politics. The National Party used the issue of abolition 'as a convenient stick with which to hit a flagging government ${ }^{759}$, especially when the maintenance of the Legislative Council as constituted carried little public support and Labour was hardly ideologically committed or enamoured with its existence anyway with many Labour MPs sympathising with the Opposition's fervour, increasing tension with the Government's tight majority. ${ }^{760}$

New Westminster conservative parties, could normally be relied upon as ardent defenders of traditional institutions, especially ones like the Legislative Council which

\footnotetext{
${ }^{756}$ National Party paper entitled "The Defeat of the Labour Government 1949”, 14 August 1950, Campaign Papers 1951, Marshall Papers, MS 1403-563/4, ATL

${ }^{757}$ Undated notes in Holland Papers, Legislative Council 1946-49, MS 1624-60/6, ATL

${ }^{758}$ Notes 1946-47 in Opposition Papers 1940-49, Holland Papers, Legislative Council 1946-49, MS 162460/6, ATL

${ }^{759}$ Andrew Stockley, "Bicameralism in the New Zealand Context", Victoria University of Wellington Law Review, Vol. 16, 1986, p 391

760 Labour MPs Finlay, Kearins and Langstone for instance supported abolition. See Jackson, The New Zealand Legislative Council - A Study of the Establishment, Failure and Abolition of an Upper House, $\mathrm{p}$ 188; Jackson, "The Abolition of the New Zealand Upper House of Parliament" in Two Into One - The Politics and Processes of National Legislative Cameral Change, pp 54-55 and Wilson, An Outsider Looks Back - Reflections on Experience, pp 149-151
} 
was, though inadequately, modelled on that most uniquely English of parliamentary institutions the House of Lords. Yet Holland, who like Churchill preferred Empire to Commonwealth, wanted abolition not reform. Holland had decided to press the issue by producing a Private Members Bill that advocated complete abolition. Abolition of second chambers of that era usually were preceded by revolution, coup or regime collapse such as in Hungary (1945), Egypt (1952), Iraq (1958) and Cuba (1960) and were carried out by radical leftist parties. ${ }^{761}$ The New Zealand National Party was anything but a junta of radical leftists, but New Zealand without such dramatic circumstances was the Westminster that once again proved to do things rather differently and accomplished fundamental constitutional and parliamentary change.

Holland preferred instant eradication of a traditional component of a Westminster Parliament, rather than modification or even incremental change. Holland and his shadow Attorney-General, Clifton Webb wanted to achieve abolition of the Legislative Council immediately and only then deliberate whether an alternative was necessary. Webb argued amazingly that if we find we have a made a mistake and that there is a need for a Second Chamber, it will be an easy matter to arrange for one...It will not be much of a confession of error to make' ${ }^{762}$ Essentially the position was abolish now and reflect later. This was party politics not constitutional deliberation and as such when reviewing the events and debates you cannot escape the conclusion of the degree of constitutional naïveté [that] is breathtaking and probably could only occur in a small state lacking a history of thoughtful debate on constitutional issues' ${ }^{763}$

Keith Jackson, the authority on the Legislative Council, asks the valid question of why Holland 'chose abolition in preference to reform?' and how he was able to impress the idea upon Parliament?

There appear to have been three main reasons. Reform lacked the dramatic impact of abolition and would have failed in the primary purpose of discomforting the Government. The dissidents favoured abolition and no Party member would be likely to support a National Party scheme for reform. And

\footnotetext{
${ }^{761}$ Louis Massicotte, "Legislative Unicameralism: A Global Survey and a Few Case Studies", The Journal of Legislative Studies, Vol. 7, No. 1, 2001, pp 155-156

${ }^{762}$ Parliamentary debate cited in Jackson, "The Abolition of the New Zealand Upper House of Parliament" in Two Into One - The Politics and Processes of National Legislative Cameral Change, p 55

${ }^{763}$ Jackson, "The Abolition of the New Zealand Upper House of Parliament" in Two Into One - The Politics and Processes of National Legislative Cameral Change, p 55
} 
lastly, reform was impracticable as a policy. Abolition, therefore, provided a simple direct challenge to the Government which would be difficult to avoid. There can be little doubt that Holland himself, a wily political tactician, sincerely believed that the upper house was useless and not worth replacing, but it is doubtful whether many members of his own party shared his belief. So for most National Party members it was acceptable only as a temporary expedient which went against their true beliefs. ${ }^{764}$

However, Fraser, himself a shrewd and more experienced political operator, had an answer for the National Party and its leader, which would surprise and gain the impetus from National and hopefully delay and even deflect the issue of the Legislative Council. Fraser responded to Holland's August 1947 “disloyal" initiative for abolition by responding with his own "radical" constitutional change. The Prime Minister reported that he was in favour of a single house, but that prior to any constitutional change it was necessary that 'the Statute of Westminster be extended to the Dominion' with the 'desirability of making the House of Representatives the sole legislative chamber'. ${ }^{765}$ Abolition would require, Fraser argued, requesting the Imperial Parliament to do so, as New Zealand did not technically possess this sovereign right, since it had not passed the 1931 Statute of Westminster due to constitutional lethargy and political animus. As was discussed in depth in an above chapter New Zealand members of parliament from across the House of Representatives including Fraser and Holland did not in any way see the Statute of Westminster as giving independence from Britain, but at its most generous it was viewed as nothing more than a piece of parliamentary housekeeping to bring New Zealand in to order with the other members of the Commonwealth.

Like the issue of adopting the Statute of Westminster, the idea of abolishing the Legislative Council was more to do with party politics and personalities than sober and reflective constitutional symposia. Fraser, though far from being an absolute advocate of the Statute of Westminster, forced the Empire loyalist National Party to delay their abolition proposal so as to debate the complex legal issues and merits of parliamentary independence and though neither side gravitated to it with enthusiasm it gained valuable delay for the Government. Holland and Fraser would have agreed with this Public Service explanatory note on the Statute:

\footnotetext{
${ }^{764}$ Jackson, The New Zealand Legislative Council - A Study of the Establishment, Failure and Abolition of an Upper House, $\mathrm{p} 185$

${ }^{765}$ Evening Post, 7 August 1947
} 
Will Adoption of the Statute of Westminster Weaken Imperial Ties? The answer is unhesitatingly - No. The tie between Britain and New Zealand will be confirmed and strengthened. It would be a sorry day if the New Zealand people were told that their relationship with the people of Britain might be weakened merely because New Zealanders desired that legislation on New Zealand affairs passed by their own representatives in their own Parliament should no longer run the risk of invalidation and annihilation by means of a British Act of Parliament which was quite unsuited to the needs of New Zealand today - over eighty years afterwards. ${ }^{766}$

Though they were not culturally weakening ties in Britain they were by their advocacy and eventual abolition of the upper house weakening the institutional loyalty with the mother of all Westminsters. The eventual adoption of this powerful and significant Act in November 1947 was almost ignored, but for all its cultural distaste to many it allowed Holland to rejoin his task of attacking the Government and abolish the Council, which the now independent legislature was empowered to do.

Fraser once again cleverly instigated a largely time-wasting activity of establishing a Joint Constitutional Reform Committee of both houses in early 1948. Though the Committee received much information about Commonwealth and international practices, heard from scholars and interested parties, the process was not taken seriously and was seen by the House of Representatives members from both parties as ignorable, especially proposals from the Council itself for reform. The MPs followed their leaders' instructions again and thereby displayed petty politics rather than acting seriously as constitutional arbiters.

... the Committee itself could not decide on a recommendation, and it appears from the debates which ensued that Members did not avail themselves of the material placed at their disposal; nor did they undertake the admittedly arduous task of forming a balanced opinion. The Committee of the Legislative Council

\footnotetext{
${ }^{766}$ Explanatory notes on Statute of Westminster, Statute of Westminster 1927-1947 File, EA 1 159/1/5 Part 4 IA 1 123/6, Archives New Zealand
} 
did submit a list of recommendations, but the Select Committee of the House [of Representatives] did not even submit counter proposals. ${ }^{767}$

Reform proposals from the Council, calls for a referendum on the issue and claims for careful consideration were blithely ignored. Holland was very careful to ensure his position on the matter was maintained. Writing to fellow National members of the Joint Committee he recognised that the Committee itself was established for political and not constitutional reasons.

The setting up of a Select Committee is merely a dodge to side-track the Second Reading of our Abolition Bill. To have us on a Committee is tantamount to using our Members to now examine our own policy which we have already done and to try and find some alternative to it. If the Labour Party had been in our position I think they would have refused to sit on such a committee and perhaps we should have done the same - but perhaps we are just as well to know what is going on, on the Committee, but I am in no mood to help in the framing of an alternative to our own policy plank. Setting up the Committee is only a dodge to beat us and we shouldn't allow ourselves to be so used.

Holland instructed his party colleagues to 'just sit in and listen' and to avoid cooperation with the Opposition on the matter. ${ }^{768}$ Fraser succeeded in delaying the issue until the 1949 election for he, like Holland, did not want a referendum, which was unlikely to bring abolition, but which could have embarrassed the government by supporting a modified upper house that would not only would rob him of patronage, but a reformed upper house could feel strengthened to act 'as a brake' on future legislation. $^{769}$ However, the activities of both party leaders did succeed in giving the Legislative Council greater attention than it had commanded for years. Yet this was almost wholly unfavourable attention and would become an issue at the election on 1949, which ushered in the first National Government, was ravenous for executive power and intent on clearing any institutional hurdles to its dominance.

\footnotetext{
${ }^{767}$ Harry J. Benda, “The End of Bicameralism in New Zealand”, Parliamentary Affairs, Vol. IV, No. 1, Winter 1950, p 67

${ }^{768}$ Holland to W. A. Bodkin MP, W. S. Goosman MP, G. H. Mackley MP, T. Clifton Webb MP and R. M. Algie (National Members of the Constitutional Reform Committee), 5 February 1948, Holland Papers, Legislative Council 1946-49, MS 1624-60/6, ATL

${ }^{769}$ Jackson, The New Zealand Legislative Council - A Study of the Establishment, Failure and Abolition of an Upper House, pp 191-193
} 


\section{The Holland Deception - Unicameralism Unleashed}

An interesting facet of Sidney Holland was his surprising skill as an amateur magician, which amused all from kids to kings. ${ }^{770}$ His greatest political trick was to make the Legislative Council disappear on 1 January 1951. The success of his sorcery was such that no one really knew if the upper house would reappear or not and nor did anyone exactly know how the trick was performed and able to deceive almost everyone. The National Party 1949 election material contained direct reference to its objective of abolishing the Legislative Council, but also gave ambiguous promises for an 'alternative'. After stating that the 'The National Party is composed of people who are unswervingly loyal to their King and Country, and who desire to promote a strong and united British Commonwealth and Empire' the party's manifesto stated:

The Legislative Council as at present constituted has failed in its purpose as a revising Chamber and should be abolished. As the Government, the National Party will examine the possible alternatives to provide for some form of safeguard against hasty, unwise or ill-considered legislation. ${ }^{771}$

New Zealand was being told that a National Government would eradicate the Legislative Council and would then search for 'possible alternatives' rather than the other way round. Holland's successful advocacy that derided the almost indefensible Legislative Council as it was 'presently constituted' allowed him the crucial advantage of satisfying the abolitionists in his party as well as the bicameralists with the vague undertaking to examine alternatives for a new upper house. Before taking office the National caucus discussed abolition and due to Holland's dominance and the Legislative Council's ineffectiveness and an overwhelming eagerness for power, the caucus agreed in favour of the abolition as an advantage over Labour. Marshall, who could be counted

\footnotetext{
${ }^{770}$ The British High Commissioner recalled of Holland that 'at every dinner party, whether he was host or guest, he performed his conjuring tricks with the zest of an overgrown boy, delighting to remove your waistcoat without removing your coat', Mallaby, From My Level - Unwritten Minutes, p 73; Gustafson, The First 50 Years - A History of the National Party, pp 63-65 and Redmer Yska, All Shook Up - The Flash Bodgie and the Rise of the New Zealand Teenager in the Fifties, Auckland: Penguin, 1993, p 25 771 "New Zealand National Party - Policy - General Election 1949" in Marshall Papers, Campaign Papers 1949, MS 1403-562/3, ATL
} 
as a bicameralist, recorded in his notes of the meeting that 'those who favour bicameral system support abolition of the present Legislative Council' presumably because they naïvely believed they could replace it afterwards. ${ }^{772}$ The 'dissidents in caucus' were mainly lawyers and had to be satisfied with the circumlocutory path of looking for alternatives. $^{773}$ Holland politely acknowledged proposals for reform and the need for an upper house from certain MPs and party members, but shrewdly never committed to do anything other than consider them. ${ }^{774}$

Just over month after finally gaining the seals of office the fresh National Government, true to Holland's enthusiasm for abolition, set to work to truncate parliament, which now as Prime Minister he had the power to achieve. The new Prime Minister asked his largely inexperienced Cabinet on how they should effect abolition, already realising that 'further appointees' would be required. ${ }^{775}$ Now as Prime Minister Holland, if he ever lacked it, he had the confidence to fully press his point that abolition would happen first and consider alternatives later. The leading bicameralist, Ronald Algie, questioned this constitutionally hazardous method.

Mr Algie stated that while he accepted the general view that the present Second Chamber as at present constituted should be abolished, he still considered that a Second Chamber was necessary and would have preferred that the constitution of the new Chamber had been settled before action was taken to determine the present body.

In the discussion certain members expressed the view that the Second Chamber should be maintained as part of the New Zealand Constitution, that this should be established before the present Second Chamber is abolished, and that it was important that the Constitution impose checks upon any future Parliament which may seek, by constitutional amendment, to destroy the present system of representative Parliamentary Government.

\footnotetext{
${ }^{772}$ National Caucus Meeting, 11 August 1949, Marshall Papers, Caucus Notes 1947-1949, MS 1403016/5, ATL

${ }^{773}$ Marshall, Memoirs Volume One: 1912 to 1960, p 94 and 158

${ }^{774}$ Holland Papers, Legislative Council 1946-49, MS 1624-60/6, ATL

${ }_{775}$ Cabinet Minutes, 18 January 1950, [CM (50) 1], Cabinet Minutes - Prime Minister's Copies

December 1949-June 1950, AAFD 808 1A (49) 1-(50) 39, ANZ
} 
To this reasonable proposal Cabinet minutes nonchalantly record the defeat of Algie's suggestion since 'on the other hand, the majority felt that action should be taken immediately to determine the present Second Chamber', ${ }^{776}$ which show that Holland personally dominated Cabinet.

Holland now met a suspicious Parliament to defend abolition without setting before it any concrete alternative. Holland told the House that the Legislative Council was a 'costly farce' made up of a clear majority of people that 'had publicly proclaimed their opposition to the policy of the present Government', which could only succeed in the years 1935-39 in initiating the Alsatian Dog Bill (which lapsed) and nothing after that and concluded that there 'is no further justification for its retention' though in presenting his catalogue of the Council's crimes he still needed reminding on its history. ${ }^{777}$ Labour, who had made no move in their manifesto to defend the Upper House, nonetheless saw that Holland was attempting constitutional deception by pledging to search for an alternative once abolition was complete. Holland's when accused by Labour of promising an alternative. He retorted: 'No, I did not promise an alternative. I promised to search for an alternative'.

Fraser contended then that Holland was stating 'not what he promised the electorate' and wanted the Prime Minister to say truthfully that the Government 'is out to abolish the second chamber and that it does not believe in anything but one chamber' with no intention of getting an alternative adding correctly that 'the proposal is revolutionary and unique in the British Commonwealth'. Holland's short and indirect responses allowed Fraser to conclude that the House had 'a confession that the statesmanship of the Government has failed. They cannot suggest any alternatives to the Legislative Council as they led the electors to believe they would'. As such Fraser considered the abolition itself to be in National Party policy words, 'hastily considered'. Holland did not ever respond to the accusation that he wanted New Zealand to become a unicameral state. The Prime Minister left the replying to these charges to his staunch ally and now Attorney-General, Clifton Webb, who argued that it would be difficult to find an alternative so quickly and the Government 'did not feel justified in putting the country any longer to the expense of maintaining an institution that has outlived its usefulness' -

\footnotetext{
${ }^{776}$ Cabinet Minutes, 1 March 1950, [CM (50) 9], Cabinet Minutes - Prime Minister's Copies December 1949-June 1950, AAFD 808 1A (49) 1-(50) 39, ANZ

${ }^{777}$ NZPD, Vol. 289, 19 July 1950, pp 539-541
} 
using a common New Zealand ploy of advancing financial considerations over constitutional proprieties. ${ }^{778}$

Parliament was debating party politics not conspicuous constitutional arguments over the pros and cons of bicameralism. Holland was able to convince his party and parliament that he was only getting rid of a "useless appendage", but not necessarily saying this would be permanent. As he slyly told National supporters in 1949 'first we should abolish the Legislative Council and then run along without one and see what need there is in the future, if any, for a Legislative Council'. ${ }^{779}$ As Andrew Stockley remarks -

What is perhaps most remarkable in retrospect is not so much the role played by party politics and the consequent lack of reasoned discussion of the issues but rather Holland's ability to keep abolition and Unicameralism distinct. The vast majority of his own party and the preponderance of public opinion seemed to favour bicameralism. Yet despite this New Zealand became and has remained a unicameral state. The irony perhaps is that no decision was ever made for New Zealand to become unicameral. It just happened. ${ }^{780}$

In the Second Reading of the Bill, Holland argued that he was not breaking any British traditions, but instead was making Parliament more 'efficient' by ridding the country of the appointed appendage. The Prime Minister stated that if a satisfactory alternative could be found he would put it to the people rather than just introduce it before giving it to the country for consideration. The Treasury benches scolded forth that Labour had themselves at times in its history advocated abolition. Fraser rebutted that Labour was not in favour of the Legislative Council and that they were different from National since 'we did not propose to abolish the Upper House before finding an alternative'. Holland, in giving what he believed were generous assurances, ominously warned the House that 'if we wanted to, we have the power. We could extend this Parliament - its life - for ten years. You cannot stop us. No one can stop us if we make up our minds'. ${ }^{781}$

\footnotetext{
${ }^{778}$ NZPD, Vol. 289, 19 July 1950, pp 546-556

779 (Cited by former National Minister and High Commissioner to Britain, L. W. Gandar) in "The Role of Second Chambers: The Report of a Study Group of the Commonwealth Parliamentary Association", The Parliamentarian - Journal of the Parliaments of the Commonwealth, Vol. LXIII, No. 4, October 1982, $\mathrm{p}$ 226

${ }^{780}$ Stockley, "Bicameralism in the New Zealand Context", pp 391-392

${ }^{781}$ NZPD, Vol. 289, 26 July 1950, pp 722-727
} 
Holland was reminding the elected representatives the powers of a modern New Zealand Prime Minister. Despite the partisan bravado in the debating chamber all either seemed to recognise the Prime Minister's power and futility in resisting it or did not see the merit in defending the continuance of the Legislative Council. Perhaps the job was made easier by the fact that the Superannuation Act, which gave a pension to all MPs, was passed a few years earlier by Labour and thus further eroded the need or interest in the Legislative Council as a paid retirement home for those tired of heady passions of the House of Representatives. ${ }^{782}$ As Algie later remembered with concern 'it is worthy to note that the Second Reading was carried on the voices and without a call for a division' giving the country conspicuous unicameralism with the greatest ease and minimum of trouble. ${ }^{783}$

And yet for all Fraser's wily dissections of National Party policy the country got unicameralism without serious constitutional debate. Not even a division was required to usher in this constitutional revolution, which would be a critical juncture with path dependent consequences demonstrating the ease of prime ministerial power and constitutional dismantlement. No one in the House of Representatives ever directly interjected, as future National MP and minister Dan Riddiford would have wanted, 'in favour of a second chamber as a necessary safeguard against a single assembly seizing excessive power, and against the further danger of an ambitious politician, through his dominance over his party, virtually becoming a dictator' ${ }^{784}$ Riddiford wrote this piece just after the constitutional dramas of 1951 with the waterfront strike, emergency regulations and snap election, which some argued could have been prevented or mitigated by an upper chamber that had only recently vanished. ${ }^{785}$

Holland was able to deliver abolition by prime ministerial patronage in stacking the upper house with a "suicide squad" or as Fraser called them the "Guy Fawkeses'.786 Holland was fortunate that ten vacancies became available in March 1950 including the

\footnotetext{
782 Jackson, "The Abolition of the New Zealand Upper House of Parliament" in Two Into One - The Politics and Processes of National Legislative Cameral Change, p 56

${ }^{783}$ R. M. Algie, "The Second Chamber in New Zealand", The Parliamentarian - Journal of the Parliaments of the Commonwealth, Vol. XLII, No. 3, July 1961, pp 204-205

${ }^{784}$ D. J. Riddiford, "A Reformed Second Chamber", Political Science, Vol. 3, No. 2, September 1951, p 23

785 Jackson, The New Zealand Legislative Council - A Study of the Establishment, Failure and Abolition of an Upper House, p 201

${ }^{786}$ NZPD, Vol. 289, 5 July 1950, p 146
} 
Speaker allowing the Prime Minister to put in his own men. ${ }^{787}$ Holland discussed in June 1950 with Cabinet the need for 'a sufficient number of new Councillors to ensure passage of the Government's legislation, and the gentlemen who might be appointed. It was decided that twenty-six councillors be appointed for this purpose', but before the Cabinet could discuss the mechanics of the very political act of appointing the "suicide squad" the Cabinet Secretary was asked to absent himself from this crucial meeting. ${ }^{788}$ Though Jackson has argued that no formal pledges were required ${ }^{789}$ from the new councillors to ensure abolition, Holland in fact did write to the prospective councillors who were obviously National supporters, that 'It would, of course, be a condition of appointment that you would implement the Government's policy, including the abolition of the Legislative Council'. ${ }^{790}$ The appointment of twenty-five members was the largest example ever of "swamping", which allowed the Government in Holland's eyes to get out of 'an intolerable situation' of having members who were 'politically opposed' to his Government. ${ }^{791}$

Though the very simple bill of abolition contained a clause that the Crown was not liable for giving compensation to any ex-Councillors, Holland did sweeten the deal for those who were to vote themselves out of a job. Councillors were allowed to keep their generous first class travel privileges for life, were paid $£ 300$ p.a. for the balance of their term which they would have served if abolition had not happened and would retain their use of the General Assembly Library. ${ }^{792}$ Also Patrick Gordon Walker, Minister at the Commonwealth Relations Office confirmed from London that 'the King has been pleased to approve of the recommendation of the title "Honourable"... for life" ${ }^{793}$, which had long been a sought after adornment of being a Legislative Councillor, while William Polson, Holland's friend and the last Leader of the Legislative Council, became Sir William not long after abolition.

\footnotetext{
${ }^{787}$ Jackson, The New Zealand Legislative Council - A Study of the Establishment, Failure and Abolition of an Upper House, p 195

${ }^{788}$ Cabinet Minutes, 16 June 1950, [unnumbered], Cabinet Minutes - Prime Minister's Copies December 1949-June 1950, AAFD 808 1A (49) 1-(50) 39, ANZ

789 Jackson, The New Zealand Legislative Council - A Study of the Establishment, Failure and Abolition of an Upper House, p 196

${ }^{790}$ Letter from Holland to prospective Councillors, June 1950, contained in A16 Papers Relating to the Abolition of the Legislative Council, Sir Alister McIntosh Papers, MS 6759-051, ATL

${ }^{791}$ Statement by Holland, 20 June 1950, contained in contained in A16 Papers Relating to the Abolition of the Legislative Council, McIntosh Papers, MS 6759-051, ATL and see Jackson, The New Zealand Legislative Council - A Study of the Establishment, Failure and Abolition of an Upper House, p 196

${ }^{792}$ Legislative Councillors - Privileges on Vacation of Office - 23 November 1950, (agreed by Cabinet 20 November 1950), IA 1 123/6, ANZ

${ }^{793}$ Legislative Councillors, AAFD 811 16H 42/5/3 Part 1, ANZ
} 
F. G. Young of the Opposition irreverently asked Polson whether the Legislative Council could have a secret ballot on abolition, since Holland had wanted such ballots imposed on the trade-union movement and if so Young, who was against abolition, speculated the Bill would fail since he questioned how deep abolition was in the Government councillors hearts. ${ }^{794}$ The new councillors however did as they were told and after further strengthening of four members and encouragement did indeed all faithfully discharge their duties' and voted themselves out by 26 votes to 16 on 22 August 1951 though unlike the lower chamber there were five divisions and lengthy debate. $^{795}$

The Clerk of the Parliaments presented the Bill in person, banged the doors and bowed at the bar of the House: a highly unusual act, but a highly unusual occasion. ${ }^{796}$ At its final session on 1 December 1950, before it would cease to exist on 1 January 1951, Marshall recorded that he escaped the lower house and "went and sat quietly, and a little sadly, in the public gallery of the Legislative Council Chamber. There was no one else there. I was the only one who came to the bedside, as the tired, dispirited and abandoned institution faded out, unhonoured and unsung'. ${ }^{797}$

\section{The Early Consequences and Realities of Abolition}

Lord Cooke, arguably New Zealand's greatest jurist, in an article on the republican debate argued that it would be a 'constitutional revolution' if the House of Representatives were to pass a bill abolishing the monarchy since not only would great change ensue but 'arguably it would also be illegal' since it could be disputed whether Parliament was competent to completely abolish a fundamental component of the legislature, which the Crown undoubtedly is. ${ }^{798}$ In the same piece, but in a less well known passage he also queries the legality of abolishing the Legislative Council as a constituent part of Parliament like the Crown, though admittedly less prominent legally and factually. The former President of the Court of Appeal though not disagreeing with the 'pedigree' of the New Zealand legislature's powers to change 'internal details' of Parliament again intimated his constitutional concern over abolition though he was 'not

\footnotetext{
${ }^{794}$ NZPD, Vol. 290, 15 August 1950, p 1442

795 Jackson, The New Zealand Legislative Council - A Study of the Establishment, Failure and Abolition of an Upper House, p 197 and see NZPD, Vol. 290, 3-31 August 1950

${ }^{796}$ Martin, The House - New Zealand's House of Representatives 1854-2004, p 235

${ }^{797}$ Marshall, Memoirs Volume One: 1912 to 1960, p 159

${ }^{798}$ Sir Robin Cooke, “The Suggested Revolution Against the Crown” in Essays on the Constitution, Philip A. Joseph (ed.), Wellington: Brooker's, 1995, p 30
} 
aware that the validity of the abolition has ever been seriously questioned' ${ }^{799}$ Cooke concedes elsewhere from a legal perspective that in regard to the Legislative Council's abolition 'it has been assumed that this was valid. If not, the Courts have long since acquiesced in a legal revolution'. ${ }^{800}$

Legal or illegal the Legislative Council disappeared and 'abolition bears testimony to the power that can be wielded by a determined party leader, ${ }^{801}$ In an international overview of unicameralism Louis Massicotte believes that the 'circumstances that led New Zealand to become the first country in the Commonwealth to opt for unicameralism for its national legislature owe little to the tireless efforts of reformers, and much to a single individual, National Party leader Sidney G. Holland' ${ }^{802}$ The abolition had path dependent and delegative democracy overtones for the state of the New Zealand Westminster system and showed the ability of a political leader to make a critical juncture. The New Zealand Westminster was the model elective personalist dictatorship. Holland, due to his overt loyalty to the Queen and Britain, did not appear a dictator, but behind the deference to the British façade was able to wreak havoc on the political system and establish major deviations and mutations to New Zealand's Westminster system.

Abolition showed the "purity" of the New Zealand executive over all other political actors. There had never been a written constitution, which could have made it legally and procedurally difficult to abolish the Council; there was no federal system that would in all likelihood judging from comparable examples in India, Australia and Canada make an upper a constitutionally stipulated part and thus cause institutional resistance to abolition; and now that the Statute of Westminster had been passed not even Imperial Westminster could intervene to save an institution they themselves had granted to their "loyal" offspring in the South Pacific. New Zealand's unabashed unicameralism was without comparison in the Westminsters. Even Britain with its unitary and unwritten constitutional character could count on stronger conventions governing its executive, which was not as dominant, and had a well established upper chamber that was and is acknowledged as an integral part of the original Westminster.

\footnotetext{
${ }^{799}$ Cooke, "The Suggested Revolution Against the Crown", pp 31-36

${ }^{800}$ Sir Robin Cooke, "Fundamentals", New Zealand Law Journal, May 1988, p 164

${ }^{801}$ Jackson, "The Abolition of the New Zealand Upper House of Parliament" in Two Into One - The Politics and Processes of National Legislative Cameral Change, $\mathrm{p} 73$

${ }^{802}$ Massicotte, "Legislative Unicameralism: A Global Survey and a Few Case Studies", p 158
} 
Ironically, when one considers the debates over the Statute of Westminster in New Zealand, those who had been against the Statute due to its supposed "disloyalty" were now the same politicians who were making a revolutionary constitutional change from the Westminster model - the first to do so of all the Dominions. The Westminster model at the central level had always been bicameral. Doidge who was now Foreign Minister had said for example in 1947 from the Opposition benches while attacking the Statute that 'we are proud of the granite strength of our loyalty, proud of our British heritage enshrined as it is in the British throne' ${ }^{803}$ Obviously he and others did not consciously consider the Westminster institutions or conventions "granite", not even bothering to craft a new structure from the constitutional ruins of the Legislative Council.

Not until Ceylon abolished its Senate twenty-two years later in 1972 did the Commonwealth have a successor to New Zealand's brazen axing of bicameralism, though even this was done by a recently elected Socialist ministry that would soon declare the country a Republic ${ }^{804}$, rather than a conservative Empire loyalist party like National. In the final debates on abolition in the Legislative Council, long-serving Councillor Sir William Perry, who was not a Labour appointment and was respected on all sides, pondered New Zealand's impressive example and lead on many issues but added 'there no doubt have been occasions when New Zealand has led the world, or tried to lead the world, in a wrong direction'. Sir William wondered what the Commonwealth would think, especially the three new Dominions of South Asia, since it may 'come somewhat as a shock to them to find that New Zealand, which - whether it be true or not I am not prepared to say - has always been proclaimed as the most loyal of His Majesty's dominions, has adopted legislation of this kind [Abolition Bill], getting, or breaking again, further and further away from the moorings' of the 'Empire Parliaments'. 805

Few formal constitutional checks remained on prime ministerial delegative democracy power. The Governor-General had the power and arguably the right to intervene not only on abolition, but on the issue of "swamping". Whereas Lords Onslow and Glasgow as Governors in the 1890s had balked at the suggestion of creating a dozen

\footnotetext{
${ }^{803}$ NZPD, Vol. 279, 7 November 1947, P 538

${ }^{804}$ See B. C. F. Jayaratne, “Abolition of the Senate of Ceylon”, The Parliamentarian - Journal of the Parliaments of the Commonwealth, Vol. 53, No. 2, April 1972, pp 104-112

${ }^{805}$ NZPD, Vol. 290, 8 August 1950, pp 1152-1153
} 
councillors $^{806}$, Freyberg is not recorded as even demurring and certainly there was no delay in assenting to over twenty-five councillors almost immediately, a number more than double the figure his predecessors thought excessive and was the greatest and most blatant example of "swamping" in the history of the Council's near century of existence. Though the Government had a mandate to abolish the Legislative Council, they also had accompanied that position by pledging an alternative.

Sir Ivor Jennings has argued that the Queen 'would be justified in refusing to a policy which subverted the democratic basis of the Constitution'. 807 Arguably as Lord Cooke hinted above there is some doubt as to the validity of Parliament to abolish the Legislative Council and therefore its abolition could be seen as arguably subverting the constitution. The same argument could apply to the conspicuous "swamping" of the upper house, with the intent of abolition of a fundamental component of the constitutional structure. Freyberg, arguably, would have been within his rights to insist on a planned alternative to replace the Legislative Council, which had been stated in the National Party Manifesto or possibly even demand an election. ${ }^{808}$ Freyberg instead chose to acquiesce to Holland's command and not act as the guardian of the constitution and system. His Royal Assent would change the country's constitutional structure forever without hindrance or pause. Not in complete hyperbole could Legislative Councillors question that as there seemed to be no checks or balances whether some future Government 'might extend its life indefinitely, abolish the oath of allegiance and abolish the office of Governor-General' ${ }^{809}$

Holland did agree to the establishment of a select committee in September 1950 to examine possible alternatives. However, it was instantly hamstrung by Labour's refusal to participate, thus further eroding the already difficult possibility, of re-establishing a bicameral system, which had only just been abolished. Fraser stated that the Labour Party wanted Holland to know that 'as the Government decided to abolish the

\footnotetext{
${ }^{806}$ See McLean, The Governors - New Zealand's Governors and Governors-General, pp 139-144

${ }^{807}$ Jennings, Cabinet Government, p 412

${ }^{808}$ Indeed if one looks back at the 1909-1911 constitutional crisis in Britain Edward VII argued against Asquith's request to create sufficient peers to pass Lloyd George's budget. The King 'would not feel justified in creating new peers until after a second general election' since it 'was tantamount to the destruction of the House of Lords', but did undertake to do so if the Government was returned. George V who succeeded his father in 1910 was even able to persuade the partisan politician to hold a constitutional conference to allay the need for mass "swamping" of ermine. See Bogdanor, The Monarchy and the Constitution, pp 113-122 and Roy Jenkins, "Mr Balfour's Poodle - People v. Peers", new edition, London: Papermac, 1999

${ }^{809}$ NZPD, Vol. 290, 15 August 1950, p 1443
} 
Legislative Council as part of the work of the first session of Parliament after is assumed office, without any prior consultation with the Opposition in regard to any possible substitute or new form of revisionary body, they are of the opinion that the question is solely and entirely the responsibility of the Government' 810

Holland could hardly be surprised and was in all likelihood pleased since it would detract from the influence of the bicameralists, who could not have bipartisan support. Labour in fact took little interest in the issue of bicameralism and further declined to debate the issue or report when it came out in 1952 since they had obtained the guarantee that National would not introduce a new upper house without public endorsement. ${ }^{811}$ The report was commissioned by Holland to 'absorb the energies of the leading bicameralists of the National Party' and to demonstrate the difficulty of finding a solution to suit everyone. ${ }^{812}$ The report allowed the fiction of finding "an alternative", but without prime ministerial or Opposition support it had little chance of succeeding.

Holland, acting as a delegated democracy leader, had no wish to be restricted by a constitution or senate as in the Australian system, which his Empire loyalist friend Robert Menzies warned him against. ${ }^{813}$ Holland also disagreed with the value of referenda, especially when as it was far from definite that it would secure the result he wanted and he no doubt recalled from his earlier research that examples from overseas showed that 'most attempts to abolish by referendum had failed'. ${ }^{814}$ New Zealand's ad hoc stumble into unicameralism had made the Constitutional Reform Committee's job an heroic task. Just as New Zealand had been the first Westminster to abolish, the Committee now ambitiously wanted the country to be the first to reinstate bicameralism - all by the same Government. Algie, the Chairman, for all his genuine enthusiasm recognised the difficulty, which Holland no doubt appreciated when he consented to the Committee's establishment.

\footnotetext{
${ }^{810}$ Fraser to Holland, 13 September 1950, contained in Appendices to the Journals of the House of Representatives (henceforth AJHR), Report of the Constitutional Reform Committee, I-18, 1952, p 8

${ }^{811}$ Jackson, The New Zealand Legislative Council - A Study of the Establishment, Failure and Abolition of an Upper House, p 206

812 Jackson, The New Zealand Legislative Council - A Study of the Establishment, Failure and Abolition of an Upper House, p 201

${ }^{813}$ 'Anything along the lines of the Australian set-up is also unacceptable. Mr Menzies has often warned me against his constitution', Holland to Maj. The Hon. N.A. Rattray, 22 July 1955, Holland Papers, Second Chamber 1950-April 1956, MS Papers 1624-093/3, ATL

${ }^{814}$ Holland to Theo Hills (National Party Secretary), 18 May 1956, Holland Papers, Second Chamber May 1956, MS Papers 1624-093/4, ATL and "The Role of Second Chambers: The Report of a Study Group of the Commonwealth Parliamentary Association”, p 227
} 
We were asked in reality to blaze an entirely new trail for ourselves. We had no case before us in which a fully sovereign, independent, and unicameral State situated as we are today - had reverted to bicameralism of and by its own free will; we could find no instance in which a single Chamber Government had in modern times and circumstances like our own freely legislated in such a way as to re-impose a dual-chamber system upon itself. To a very great extent this novel feature in the situation, and this entire absence of precedent, made it much more difficult for us to plan a satisfactory alternative to the former Legislative Council. $^{815}$

Gallantly the National Party bicameralists, including Marshall, argued in their 1952 Report that the country should revert to bicameralism. They proposed a fixed thirty-two member "Senate" (to avoid "swamping"), which would be totally appointed and proportionate to the relative strength of the parties in the House of Representatives. The Government list would be decided by the Prime Minister, while the rest would come from the Leader of the Opposition. The Senate would have the power to amend and initiate legislation and the power to delay for two months (but no veto). Senators would have the same term as the lower house to avoid potential confrontation with changes in administration, but would be eligible for re-election. ${ }^{816}$ Interestingly there is no evidence of any proposal to have a Māori component in any of the proposals for an upper chamber, including Algie's Report. ${ }^{817}$

The Report was criticised at the time and beyond for providing 'no remedy" ${ }^{818}$ to the problematic lack of checks and balances and the members were accused of failure since 'in all the history of man there can rarely have been proposed an institution so utterly powerless'. ${ }^{819}$ Such comments are unfair when one considers the problems the Committee faced. They knew their leader's disdain for bicameralism, and probably hoped that their proposal for a measured return to "nomineeism" would be more likely

\footnotetext{
${ }^{815}$ AJHR, Report of the Constitutional Reform Committee, p 5

${ }^{816}$ AJHR, Report of the Constitutional Reform Committee, pp 11-18

${ }^{817}$ As long ago as the 1890s King Tawhiao and others had been advocating a 'legislative council of chiefs', but like most constitutional proposals in New Zealand after initial enthusiasm the proposal came to nothing. See Walker, Ka Whawhai Tonu Matou - Struggle Without End, p 165

${ }^{818}$ H. J. Benda and R. H. Brookes, "SPQR: A Note on the Proposed Senate", Political Science, Vol. 4, No. 2, September 1952, p 43

${ }^{819}$ Otago University Law Lecturer Maurice Joel cited in Palmer, Unbridled Power - An Interpretation of New Zealand's Constitution \& Government, $2^{\text {nd }}$ edition, $\mathrm{p} 235$
} 
to induce support from the Prime Minister than a rival popularly house, which many hoped. At least a nominated upper house, that had learnt the lessons of past, could provide some limited form of accountability.

As G. A. Wood argues 'there is a role for an impotent upper house: unable to block, but able to advise, criticise, and publicise' which the executive would find less threatening than a powerful elected chamber like the Australian Senate. ${ }^{820}$ The Report's recommendations pleased few and unsurprisingly were never activated or put to the electorate. Holland had a characteristically artless, though exceedingly honest, response to the Report. When asked by senior journalists what he was going to do with Algie's Report he replied with candour:

I'm going to take it home, I'm going to bore a hole through the top left hand corner, and I'm going to put a piece of string in it and take it up and hang it in the outhouse. ${ }^{821}$

And remembering Holland's aversion to literature, that was that, and an upper house never returned to New Zealand's unique Westminster parliamentary infrastructure.

The issue did not completely die since there were still many in the National Party who believed it should be reinstated. Figures like the Speaker, Sir Mathew Oram, hoped to convince the Prime Minister of the dangers of the unicameral system. The Speaker argued a few years later in May 1956, perhaps appealing to Holland's partisan instincts, that 'while the possession of complete, absolute unfettered and unrestricted power in the hands of the Lower House may be quite safe and satisfactory while the present Government remains in power, it is not a state of affairs one would like to hand over to a Socialist Government should one succeed the present regime'. ${ }^{822}$ The spectre of defeat and possibility of losing his immense power had just the day earlier compelled Holland to fearfully confess the unthinkable to the National Party President: that perhaps after all an upper house would be useful.

\footnotetext{
${ }^{820}$ G. A. Wood, "New Zealand's Single Chamber Parliament: An Argument for an Impotent Upper House?", Parliamentary Affairs, Vol. 36, No. 3, Summer 1983, pp 335-336

${ }^{821}$ Cited in Gustafson, The First 50 Years - A History of the National Party, p 59

${ }^{822}$ Sir Mathew Oram to Holland, 1 May 1956, Holland Papers, Second Chamber May 1956, MS $1624-$ 93/4, ATL
} 
If Labour came again into power it may enact legislation that would make it well nigh impossible for our Party to regain the Treasury benches for many years. For example, it may pass laws, and there would be nothing to prevent it from doing so, altering electoral boundaries to its own considerable advantage. Or it may introduce some form of "Town Quota". Those are but two examples of the sort of fears that are being entertained. One, but not the only purpose of the idea of setting up a new Second Chamber is to make such a course impossible. ${ }^{823}$

Holland days later added that he did not want, like Labour had over the abolition of the "Country Quota", to furnish the electorate with such political considerations, using the curious logic that it was 'a constitutional matter and I'm not sure that an election policy is the proper place for it', even though he had in 1950 promised to put any proposals for a reformed upper house to the voters. ${ }^{824}$

Holland's motivations were once again political rather than constitutional and his concern for bicameralism emerged only briefly with the possibility of losing power as Prime Minister. The ailing Prime Minister ${ }^{825}$ believed that there might need to be greater institutional and structural accountability to mitigate the awesome powers delegated to the post-war New Zealand Prime Ministership than had otherwise existed during his own dramatic tenure for example, but only if the Opposition returned to power.

Holland lost his short-lived zeal for the upper house by the end of May 1956, when with Cabinet he believed 'that a more effective means of establishing desirable safeguards would be to provide by legislation that certain classes of proposals that might come forward, e.g. for extending the life of Parliament or varying the method of determining electoral boundaries, should be decided by referendum'. ${ }^{826}$ The National Government believed that "more effective" alternative would be stronger electoral laws through the

\footnotetext{
${ }^{823}$ Presumably "Town Quota" refers to electoral weightage to urban centres, which would favour Labour who had themselves abolished the rural weighted "Country Quota" in 1945 that had favoured National. Holland to Alex McKenzie, 30 April 1956, Holland Papers, Second Chamber 1950 - April 1956, MS 1624-93/3, ATL

${ }^{824}$ Holland to McKenzie, May 7 1956, Holland Papers, Second Chamber 1950 - April 1956, MS $1624-$ 93/3, ATL

${ }^{825}$ As recorded at the time by the Permanent Head of the Prime Minister's Department. Letter from McIntosh to [now Sir Clifton] Webb in London, 11 June 1957, Personal Correspondence, Hon. Sir Thomas Clifton Webb Papers, MS Papers 6759-365, ATL

${ }^{826}$ Prime Minister's Office to Marshall, 30 May 1956, Copied from Cabinet Minutes, 29 May 1956 [CM (56) 25], Marshall Papers, MS 1403-069/4, ATL
} 
Electoral Amendment Bill 1956. Marshall, now Attorney-General, piloted laws with Opposition acceptance, which purported to entrench sections guaranteeing the independence of the Representation Commission, electorate districts, extent of numerical deviation of population in forming electoral districts, the adult franchise, secret ballots and the triennial life of Parliament and required a seventy-five per cent vote of Parliament or a full public referendum to alter. ${ }^{827}$ However the so-called entrenched sections were not entrenched themselves and New Zealand's Westminster retained its substantial powers to do as it pleased as Marshall conceded, though with hopeful ideals to the House.

The provisions we are making in this legislation could be repealed by the next, or any subsequent Parliament. What we are doing has a moral sanction, rather than a legal one, but to the extent that these provisions are unanimously supported by both sides of the House, and to the extent that they will be universally accepted, they acquire a force which subsequent Parliaments will attempt to repeal or amend at their peril, against the will of the people. ${ }^{828}$

Marshall reported privately to Holland the day before he retired as Prime Minster that it must be remembered that 'in considering legislative safeguards for the electoral system, it must be understood that under our constitution Parliament cannot bind successive Parliaments, and each successive Parliament may amend any law passed by a previous Parliament'. ${ }^{829}$ The Electoral Amendment Act was a creative response from the executive that attempted to assure the electorate of their rights, but at the same time did not greatly remove the executive's flexibility. The Act, in the Government's eyes, ended the need for any institutional change or reform that a new upper house would have caused; again showing the New Zealand preferment of relying on convention. Even Marshall himself later saw the limitations of the "moral sanction" and advocated greater reforms to safeguard Parliament and the constitution. ${ }^{830}$

New Zealand voters grew increasingly disgruntled by their elective dictatorship, which the absence of an upper house assisted. National and Labour governments could and

\footnotetext{
${ }^{827}$ Scott, The New Zealand Constitution, pp 6-7 and Marshall, Memoirs Volume One: 1912 to 1960, pp 246-248

${ }^{828}$ Marshall, Memoirs Volume One: 1912 to 1960, p 248

${ }^{829}$ Marshall to Holland, 19 September 1956, Holland Papers, Seconds Chamber, MS 1624-093/6, ATL

${ }^{830}$ Marshall, "Introduction" in The Reform of Parliament - Papers Presented in Memory of Dr Alan Robinson, p 10-11
} 
did force through legislation that did not have a mandate from the electorate, who were powerless to resist, as were the other limited institutional actors. Largely as a result of the chaotic radical policies and events of the 1980s, the electors became restive and demanded change to the system to make the executive more accountable. The radical restructuring of the welfare state through "Rogernomics" especially after the 1987 election had occurred without being outlined in a manifesto, and thus the electorate were delegating full executive power without being pre-warned on the details or having any institutional avenue to check the executive. It is tempting to wonder whether an upper house could have resisted such change since they could have utilised and adapted the British Westminster practice known as the "Salisbury Convention", which allows the Lords the opportunity to legitimately reject legislation not explicitly mentioned in the ruling party's manifesto, which therefore had not been endorsed by the electorate. ${ }^{831}$

Due to the sparseness of New Zealand's constitutional infrastructure the idea of an upper house was suggested in the early 1990s as a potential check on the executive. Interestingly it was a National Government fifty years on that advocated a senate to answer the 'disquiet over the lack of checks and balances' as a possible alternative to full proportional representation. ${ }^{832}$ The proposal never gained substantial public support and did not make it as an option in the 1992 referendum on electoral change, which was submitted in answer to years of elective dictatorship that had become established in the Fraser-Holland era with path dependent consequences. ${ }^{833}$ The sequence of political and constitutional events, such as the abolition of the Legislative Council, which followed from the adoption of the Statute of Westminster in 1947, demonstrated that though an underrated event, it "triggered" and allowed critical actions and opportunities for the path dependent personalist power of Prime Ministers. New Zealand's Westminster executive "purity" was conspicuously demonstrated by the abolition of the Legislative Council.

\footnotetext{
${ }^{831}$ Russell, Reforming the House of Lords - Lessons from Overseas, pp 12-13

${ }^{832}$ NZPD, Vol. 518, 22 August 1990, pp 4316-4319 and see Sir Douglas Graham, "Reflections on the Constitution", New Zealand Law Review, 1999, pp 561-568 where the former the Minister of Justice argues that a thirty member Senate with Māori representation and a lower house elected by the less radical proportional system of supplementary member had been his first choice over the Mixed Member Proportional system chosen.

${ }^{833}$ See Jack Vowles and Peter Aimer, Voters' Vengeance - The 1990 Election in New Zealand and the Fate of the Fourth Labour Government, Auckland: Auckland University Press, 1993, pp 219-220 and Helena Catt, Paul Harris and Nigel S. Roberts, Voter's Choice - Electoral Change in New Zealand?, Palmerston North: The Dunmore Press, 1992, pp 119-128
} 


\title{
New Westminsters Compared
}

\author{
A Nation spoke to a Nation, \\ A Queen sent word to a Throne: \\ 'Daughter am I in my mother's house, \\ But mistress in my own. \\ The gates are mine to open, \\ As the gates are mine to close, \\ And I set my house in order', \\ Said our Lady of the Snows. ${ }^{834}$
}

With elements of flexibility, ease for local deviation and reliance on convention rather than enforceable rules, New Westminsters have always been notoriously difficult to compare with meaningful results, even before the advent of the independent non-settler cases. However loyal, no New Westminster could completely replicate the parental Westminster, and nor could any New Westminster, however disloyal, completely escape the legacy of their constitutional forebears. Whatever the intention all New Westminsters had their own inevitable peculiarities.

Most would have agreed with James Stephen that any 'analogy' with the Westminster model was 'formal and nominal, rather than real'. Local forms 'must be matters of compromise and of adaptation to the particular conditions, character, wants and resources of the place'. Moreover, even 'the closest parallelism in forms' would 'often involve the widest deviation in substance'. ${ }^{835}$

The New Westminsters of India, Ceylon and New Zealand all became sovereign states within months of each other in the late 1940s and give a unique opportunity for a triangular comparison to analyse their reaction and adaptation to the Westminster

\footnotetext{
834 "Our Lady of the Snows" in Rudyard Kipling, The Five Nations, $7^{\text {th }}$ edition, London: Methuen and Co., 1910, pp 87-89

${ }^{835}$ Peter Burroughs, "Imperial Institutions and the Government of Empire" in The Oxford History of the British Empire: Volume III - The Nineteenth Century, Andrew Porter (ed.), Oxford: Oxford University Press, 1999, p 175
} 
system. These three comparable countries provide an ability to assess the future impact of the critical executive choices taken or not taken during the crucial first ten years of independence. The interrelated three-level theoretical approach of cultural conditions, horizontal accountability and path dependence allows a far reaching focus of executive power in these influential New Westminsters.

\section{Cultural Conditions Compared}

The New Westminsters of India, Ceylon and New Zealand became independent not only in different circumstances, but also with different attitudes and values concerning the Westminster system. Bagehot's 'dignified' and 'efficient' elements of the British constitution and political culture would be applied in varying degrees to the $\mathrm{New}$ Westminster. The 'dignified' aspects of Westminster culture included symbols and practices that were directly attributable to monarchical and British cultural practices, while the 'efficient' parts related to the operating culture that surrounded Westminster institutions such as Cabinet and Parliament. When analysing the three cases the distinction, though sometimes imprecise, between 'dignified' British culture and 'efficient' Westminster culture is vital to comprehend the institutions and actions at the executive level. The New Westminsters would need to decipher and determine what features of British Westminster they would incorporate into their adapted Westminster.

India, soon to be a republic, did not want the 'dignified' culture of British Westminster and was 'disconcerted by sundry importunate British proposals' such as incorporating the Union Jack in India's new flag since the country was 'emotionally and psychologically' wary of such symbolic British importations. ${ }^{836}$ India would have a President as representative of the people and not a Governor-General representing a foreign monarch. However, B. N. Rau, Constitutional Advisor to the Constituent Assembly, was fully prepared to recommend cabinet government as practiced in Britain for India over any other model, which was readily endorsed by a Congress oligarchy that wanted the executive flexibility prevalent in the Westminster model. ${ }^{837}$ Though rejecting the monarchical 'dignified' Westminster culture India did not turn inwards to its own land for any institutional alternatives such as Gandhi's idea of village democracy.

\footnotetext{
${ }^{836}$ Krishnan Srinivasan, The Rise, Decline and Future of the British Commonwealth, Houndmills: Palgrave Macmillan, 2005, p 10

${ }^{837}$ Austin, The Indian Constitution: Cornerstone of a Nation, pp 116-119
} 
Nehru and Patel wanted Westminster-style 'efficient' and strong cabinet government and retained its identifiable western forms. They even rejected the British Prime Minister's proposal that they 'draw from Indian history distinctive titles' to replace the non-Asian names of Governor-General, Prime Minister, President and Republic. ${ }^{838}$ India, like Ceylon, even pragmatically stipulated for their nascent lower chamber the use of standing orders as used in the House of Commons thereby emulating parliamentary practices as operated in Britain that they admired, avoiding the difficult task of having to formulate their own parliamentary rules. ${ }^{839}$ However, in contrast to New Zealand and Ceylon who lapped up British Honours, India explicitly banned such titles in their constitution seeing them as tools for 'imperialistic purposes' ${ }^{840}$ Nehru outwardly rejected British ceremonial culture, but actively utilised Westminster operational culture when dealing with Cabinet, Parliament and the Congress Party.

Ceylon's elite, unlike their Indian counterparts, were happy to continue the 'dignified' aspects of British monarchical culture. For outside observers this seemed a "sham independence" as "Ceylon was claiming to be independent, but the Duke of Gloucester was opening the first Parliament of independent Ceylon, the colonial Governor had merely changed his title, and the Union Jack was flying all over the place' ${ }^{841}$ The country's leaders were happy for Englishmen to be their Governor-General and when Sir Oliver Goonetilleke became the first Ceylonese to hold the post he was diligent in maintaining the outward trappings of his office including the plumed hat and ceremonial swords of the colonial era. Whereas India could not wait to break the shackles of its colonial past and become a republic, Ceylon waited till 1972, and even then many of the old symbolic practices were retained. As one New Zealand diplomat remembered:

It was somehow characteristic of the confusion between rhetoric and practice that the Democratic Socialist Republic of Sri Lanka asked me to present my credentials in morning dress. ${ }^{842}$

\footnotetext{
${ }^{838}$ Clement Attlee to Nehru, 20 March 1949, cited in letter from Nehru to Patel, 26 March 1949 in which Nehru described Attlee's letter as a 'naïve document' in Sardar Patel's Correspondence 1945-50, Vol. VIII, pp 5-8

${ }^{839}$ This reference to the House of Commons remained in the Indian Constitution under Article 105 till 1978. See Basu, Introduction to the Constitution of India, p 205

${ }^{840}$ Article 18 abolished such titles. See Basu, Introduction to the Constitution of India, pp 94-95

${ }^{841}$ Jennings, "Crown and Commonwealth in Asia", p 140

${ }^{842}$ Hensley, Final Approaches - A Memoir, p 198
} 
The first ten years of independence showed the difficulty of practicing the 'efficient' culture of collegial party government in Ceylon when there was very little party political infrastructure in existence. Political parties underscored the successful Westminster operation of Cabinet and Parliament. This lack of well established and supported parties made Cabinets and Parliament more akin to the factionalism and nepotism of eighteenth-century Britain, which rendered the stability of ministries and genuine cabinet government difficult. ${ }^{843}$ After the death of the D. S. Senanayake, who commanded respect as the man who brought independence, Ceylon's Prime Ministers were without the discipline and extensive political networks that the leaders of the Congress Party in India or the National Party in New Zealand commanded, making Ceylon's system a factional and nebulous executive that dangerously relied on populism for strength to compensate for insufficient party support.

New Zealand as a settler transplanted Westminster had natural ties with Britain that encouraged a 'dignified' acculturation. New Zealanders generally read constitutional change as 'disloyalty' to Britain and unlike India saw this as a negative trait. ${ }^{844}$ Unlike the Ceylonese and Indian elite that dominated their nations at this time and were markedly different socially from their electorate, New Zealand leaders like Holland and Fraser "were adept at portraying their parties as representatives of "ordinary" New Zealanders... ${ }^{845}$,which nation-wide meant loyalty to British culture. Political leaders correctly assessed that they had been doing things their own way for years and did not seem embarrassed to deny passage to constitutional changes that would confirm such realities. In contrast to India, and to a lesser extent Ceylon, New Zealand's leaders were not receptive to breaking with Britain. Rather than seeing adoption of the Statute of Westminster as providing independence from Britain, New Zealand believed the opposite.

\footnotetext{
${ }^{843}$ A recent article in a Sri Lankan daily attributed many of the country's political problems to this era when Sri Lanka's highly polarised party system was hurriedly established. 'The operation of the party system thereafter proceeded with devastating effect to the country's stability, unity and progress. The people got polarized behind different parties. For most followers, their party was religion and their leaders demigods'. Daily Mirror, 2 March 2007

${ }^{844}$ See Kumarasingham, "The 'New Commonwealth' 1947-49: A New Zealand Perspective on India Joining the Commonwealth", pp 441-454

${ }^{845}$ Barry Gustafson, "Populist Roots of Political Leadership in New Zealand" in Raymond Miller and Michael Mintrom (eds.), Political Leadership in New Zealand, Auckland: Auckland University Press, 2006, p 56
} 
All that the Statute does is to bring the legal forms into line with the established constitutional position. The links with other members of the Commonwealth through common allegiance to the Crown and through kinship, tradition, partnership in war, adherence to the same democratic institutions and principles, and the beneficial interflow of trade still remain. ${ }^{846}$

However, though New Zealand political leaders of varying ideological hues were all culturally and openly devoted to the British Monarchy, this was not necessarily translated to deference or political participation of the Sovereign's Representative in Wellington. New Zealand Prime Ministers for all their cultural affinity and 'loyalty' to Britain did not expressly see any great desire to replicate the full extent of the operating culture of checks and balances available in the Westminster system that could encumber their substantial 'efficient' powers delegated from the Crown. Behind the vocal loyalty to Britain the New Zealand Prime Ministers of this era were able to exercise power to a greater extent than their British counterparts, whose powers were more circumscribed by stronger operating conventions surrounding their more pervasive Westminster institutions.

Though it was not possible to examine every aspect of cultural conditions of this era, selected examples were chosen that illustrated the wider pressures and operation of executive power in this critical era. In India the deliberations of the Constituent Assembly were fixated by the need for a strong executive with 'efficient' Westminster executive flexibility to deal with the consequences of Partition and need for territorial integrity. The Congress oligarchs that dominated the proceedings felt comfortable with 'efficient' cabinet government with a republican colour that could deliver more to India's particular needs than more rigid models such as the American system. The Ceylonese elite and their friends at the Colonial Office shared the belief that the British model was best and sought to impose it on to the wider Ceylon polity with little allowance for local conditions. The Ceylonese Cabinets with their 'dignified' anglophile acculturation of the era were strongly in favour of the British way and were confident they could operate it with success. This confidence was misplaced as they did not have the necessary party system apparatus needed to manage the Westminster system properly and by following so diligently the British Westminster, with its unitary

846 "Summary of Reasons for which New Zealand should adopt the Statute of Westminster", 7 November 1947, Statute of Westminster 1927-1947, EA 1 159/1/5 Part 4 IA 1 123/6, ANZ 
style that was blind to cultural heterogeneity. They did not have any practicable institutional mechanisms to accommodate the growing tensions of communalism.

New Zealand's reactions to the adoption of the Statute of Westminster demonstrate an invaluable contrast with a country like India. Both countries became independent in 1947 and yet they had contrasting values and attitudes towards their status. New Zealand's parliamentarians were at pains to prove that the ratification of the Statue of Westminster merely was a bit of constitutional housekeeping and not a momentous occasion heralding a new era as in India. Like Ceylon, foreign observers queried the independence of New Zealand's constitutional status met by such conspicuous 'dignified' symbolism that manifested a reliance on Britain. ${ }^{847}$ Despite New Zealand's reluctance to change, it was critically dissimilar from other New Westminsters by its culturally and institutionally simplified constitutional structure that concentrated power at the executive level.

For these three New Westminsters, the era chosen was crucial for the analysis of executive power. The cultural conditions evident in all three cases gave the executive actors considerable ability to impact their polity as few of their predecessors could, Though outwardly the evidence points to New Zealand refraining from glorifying in its new independence, the reality was that Prime Ministers in this era had power greater than before. The formal ratification of the Statute of Westminster coincided with entrenchment of the post-war two-party system which lasted till the MMP era. Together they gave future Prime Ministers formal constitutional power and political power to command Parliament, Cabinet and, with New Zealand's unwritten and uncluttered structure, the whole system itself to a level not seen in most New Westminsters. ${ }^{848}$

In India the cultural conditions dramatically gave complete power for the first time to Indians themselves. The Congress leaders and Nehru especially had the daunting task

\footnotetext{
${ }^{847}$ For example G. R. Powles reported from New Zealand's Legation in Washington that more information on the Statute of Westminster was required for explanation to the Americans - 'You will appreciate that anything connected with New Zealand's constitutional position in the Empire is a matter upon which both Mr Reid and myself are frequently asked questions by our American friends'. G. R. Powles to McIntosh, 30 September 1947, Statute of Westminster 1927-1947, EA 1 159/1/5 Part 4 IA 1 $123 / 6$, ANZ

${ }^{848}$ John Wanna, "New Zealand's Westminster Trajectory: Archetypal Transplant to Maverick Outlier" in Patapan, Wanna and Weller (eds.), Westminster Legacies - Democracy and Responsible Government in Asia and the Pacific, pp 163-165
} 
of establishing the operation and conventions of cabinet government without formal British tutelage or constraint, while trying to forge a nation and strike a delicate balance between rejecting the ceremonial 'dignified' culture of British Westminster and adopting the operational 'efficient' Westminster culture. India's political elite had to accommodate the country's massive pluralism institutionally and through constitutional protection, but retain central executive freedom and flexibility to keep the country together.

The cultural conditions in Ceylon at the executive level in the first ten years demonstrate the difficulty that the elite had in creating a successful plural democracy. Though they faced similar social conditions to India, the peaceful and cosmetic ease of the transition from colony to independent state lured the inter-communal Ceylonese elite into thinking that they could politically prosper without any need for the institutional and constitutional safeguards for minorities that would have been very unBritish Westminster in style. Those who warned against the desirability of a largely unedited Westminster implantation were ignored. The relatively peaceful and prosperous conditions lulled Ceylonese leaders and their advisors into such subjects like whether the 'dignified' creation of a titled 'Order of Sri Lanka' might add to the lustre of Crown in Ceylon instead of its more serious communal problems. ${ }^{849}$ In contrast, India's chaotic cultural conditions urgently compelled their executive to accepting the need to establish a unique form of federalism. Adaptations to the Ceylonese Westminster such as powersharing or federalism could have mitigated the communal tensions that erupted in the latter part of the first ten years that proved the imprudence of the early confidence and showed the limited acculturation of Westminster conventions of the masses of Sri Lanka.

The critical operation of these nascent political conditions was completely delegated to the local practitioners in the New Westminsters who held all the power regardless of their deference or diffidence to British culture. The cultural conditions of the first ten years enabled the various executive actors vast opportunities to substantially impact the executive itself through their actions and inactions; consciously and subconsciously.

${ }^{849}$ The Royal Visit to Ceylon, 1954, Jennings Papers, Ceylon B3, ICS125, ICS 


\section{Horizontal Accountability and Delegative Democracy Compared}

Harold Laski, that early doyen of the British Labour Party's intelligentsia, is reputed to have explained to the Soviets that 'the British Constitution works according to rules, but when it does not work to suit the gentlemen of England, the gentlemen of England change the rules'. ${ }^{850}$ The same could be said of those "gentlemen" in the New Westminsters of the post-independence decade, endowed with delegative democracy power to actively shape and mutate their Westminster legacy. With different degrees in all three New Westminsters power, as is traditionally the case with the Westminster system, was concentrated in executive actors at the expense of the legislature. For other branches of state as well and those within the executive, to be effective they needed independent power. However 'to be autonomous, institutions must have boundaries, these boundaries must be acknowledged and respected by other relevant actors, and still other actors must be available to defend and eventually redress those boundaries if they are transgressed'. ${ }^{851}$ The flexible convention based Westminster system where powers, roles and limits of the institutional actors within the state are commonly blurred and illdefined make this a highly difficult task. Those to whom power is delegated dislike any 'unnecessary encumbrances to their "mission"' that effective horizontal accountability could provide. ${ }^{852}$ According to delegative democracy theory those leaders entrusted with executive power often see other constitutional institutions like Parliament or Cabinet as 'nuisances' and in fact for delegative democracy leaders '[a]ccountability to such institutions appears as a mere impediment to the full authority that the president has been delegated to exercise' ${ }^{853}$

The leaders that emerged from the New Westminsters in the post-war period were united in the desire for a powerful state to implement their vision. The cultural and institutional legacy of their Westminster inheritance availed the newly independent executives the auspices and capability of utilising old tools for new jobs. In South Asia 'the national aspiration for a strong, unified state, ironically mimicking that of the colonial power, lay beneath the struggle for independence ${ }^{854}$ and New Zealand was no

\footnotetext{
${ }^{850}$ Cited in A. W. Bradley, "Sir William Ivor Jennings: A Centennial Paper”, Modern Law Review, Vol. 67, No. 5, 2004, p 725

${ }^{851}$ O'Donnell, "Horizontal Accountability in New Democracies", p 119

${ }^{852}$ O'Donnell, Counterpoints - Selected Essays in Authoritarianism and Democratisation, p 166

${ }^{853}$ O'Donnell, Counterpoints - Selected Essays in Authoritarianism and Democratisation, p 164

${ }^{854}$ Subrata Kumar Mitra, "Introduction" in Subrata Kumar Mitra (ed.), The Post-Colonial State in AsiaDialectics of Politics and Culture, New York: Harvester Wheatsheaf, 1990, p 1
} 
different in traditionally wanting a strong state with a 'strong government'. 855 The intra-executive actors consisting of the Head of State, Prime Minister and Cabinet were the political actors commended with the delegated power and it was the Prime Minister (in the Ceylon case in partnership with the Governor-General) who acquired the personalist power characteristic of delegated democracies.

\section{Head of State and Prime Minister}

D. A. Low has articulated the premise of executive power in the New Westminsters, which applies to the Republic of India in different terminology:

Constitutional monarchy and parliamentary supremacy [is] conjoined with cabinet government, in which executive power is exercised in the name of the constitutional monarch by those who collectively enjoy the political support of the key elected chamber of the legislature. ${ }^{856}$

Put another way this political symmetry that combines executive dominance of the elected legislature with the acquiescing assent of the Head of State often makes horizontal accountability difficult and can lead in Westminster systems to 'elective dictatorship' by the Prime Minister and Cabinet. ${ }^{857}$ The executive actors often wanted to 'acquire an elevated position...to achieve their goals' and extend their power 'by reducing the ability of veto players to interfere' with their objective of enjoying a large 'zones of autonomy,. ${ }^{858}$ In Westminster systems there are few formal "veto players" that can, or are willing to, exercise effective horizontal accountability on a determined delegative democracy Prime Minister. The individuals involved are crucial in how they direct and interpret their role and relationship with the rest of the political structure.

In all three cases the political leaders of the New Westminsters sought a Head of State that would emulate the British King. In the person of George VI (and later his daughter) the Commonwealth statesman saw an ideal Head of State that was a careful considerate constitutional head, with influence not power, and above and unsullied by party politics. The Ceylonese were explicit in their constitutional determination to be like Britain stating 'All powers, authorities and functions vested in ... the Governor-

\footnotetext{
${ }^{855}$ Palmer and Palmer, Bridled Power - New Zealand's Constitution and Government, $\mathrm{p} 12$

${ }^{856}$ Low, "Introduction: Buckingham Palace and the Westminster Model", pp 1-2

${ }^{857}$ Hailsham, Elective Dictatorship, p 5

${ }^{858}$ Poguntke and Webb, "The Presidentialization of Politics in Democratic Societies: A Framework for Analysis", p 11-12
} 
General shall ... be exercised as far as may be in accordance with the constitutional conventions, applicable to the exercise of similar powers, authorities and functions in the United Kingdom by His Majesty ${ }^{, 859}$ (similar provisions were not made on the Prime Minister). Today even New Zealand is referred to as a 'localised monarchy' with the 'constitutional domestication of the Queen' and her powers to her representative in Wellington. ${ }^{860}$ Even India's republican leaders, committed to divest India of monarchical symbols, eagerly wanted the English way and rejected the American presidential model in the Constituent Assembly. As the learned constitutional scholar Sir Alladi Krishnaswami Aiyar informed the Indian Cabinet:

... there is no sort of comparison between the position of a President under the American Constitution and that of the President under the Indian Constitution who is in every way in the position of a constitutional monarch. ${ }^{861}$

However, all three New Westminsters soon realised that it was impractical to import the British Monarch or any clone to their shores. The British monarchy cannot be localised in its historical and political entirety especially since constitutional monarchy of the British variety with its unique 'dignified' and 'efficient' culture has taken over two and a half centuries to form. ${ }^{862}$ Not only was it unfeasible, it was undesirable to the political executive and the Prime Minister especially, to have an influential counter to their own power. It was also unattainable for the local Head of State to exercise monarchical powers without the security of hereditary tenure and historical acculturation, since the local version lacked the credence of customised consultation and involvement that the British Monarch historically inspires.

The ambiguous powers of the Crown in the Westminster system rendered the influence of the Head of State as illusory and shifting; where the extent of authority was unknown and always critically difficult to decode and decide, especially so in the localised context bereft in the independence era of natural evolution and customary usages. Jennings stated in the early 1950s the difficulty of the transition:

\footnotetext{
${ }^{859}$ Ceylon Constitution, Section 4(2) in Jennings, The Constitution of Ceylon, p 169

${ }^{860}$ Ladley, "The Head of State", pp 54-55

${ }^{861}$ Note by Aiyar, 8 October 1951, Prasad: Correspondence and Select Documents, Vol. XIV, p 291

${ }^{862}$ D. A. Low, "Introduction: Buckingham Palace and the Westminster Model" in D.A. Low (ed.),

Constitutional Heads and Political Crises - Commonwealth Episodes, 1945-85, p 1-2
} 
The change of title, the elevation of the first lady to the rank of Excellency, the use of the gold crown on the blue field in place of the Union Jack, and the other changes in forms and ceremonies, are not enough to indicate that the GovernorGeneral is the representative of the Sovereign and not of the United Kingdom Government. Nor, indeed is the difference between the Queen and the Queen's Government understood: the Queen is still referred to in Ceylon and Pakistan as the 'Queen of England'. She is a foreign monarch, a symbol of Commonwealth relationship, no doubt, but a foreign symbol. ${ }^{863}$

Thus it was left to the New Westminsters to formulate their own version, whether they consciously realised this or not. The former Governor-General of Australia, Sir Paul Hasluck wrote in the early 1970s the duties of his former office:

In normal times when customary practices and procedures are being followed and the Constitution and laws of the Commonwealth [of Australia] are being scrupulously observed, the role of the Governor-General in Parliament would seem to be a matter of unbroken routine. In abnormal times or in case of any attempt to disregard the Constitution or the laws of the Commonwealth, or even the customary usages of Australian government, it would be the GovernorGeneral who could present the crisis to Parliament and, if necessary, to the nation for determination. It is not that the Governor-General (or the Crown) can over-rule the elected representatives of the people but in the ultimate he can check the elected representatives in any extreme attempt by them to disregard the rule of law or the customary usages of Australian government and he could do so by forcing a crisis. ${ }^{864}$

The Heads of State in all the New Westminsters in this era of uncertainty that came with constitutional independence were faced with situations where the 'customary usages' of their states had not been established making for constitutional ambiguity of the executive's powers. Also in that first decade all three countries faced 'abnormal times' constitutionally with various political crises that compelled exceptional reactions from the executive actors that would shape their roles and positions.

\footnotetext{
${ }^{863}$ Jennings, "Crown and Commonwealth in Asia", p 130

${ }^{864}$ Sir Paul Hasluck, The Office of Governor-General, Melbourne: Melbourne University Press, 1979, $\mathrm{p}$ 14
} 
In South Asia this was particularly complex. Apart from the obvious cultural dissimilarities as discussed above there was the danger that the Governor-General would act as a Viceroy or colonial Governor with higher expectation and opportunity for executive direction and involvement. At the time of independence the British Cabinet and the King feared that there was a danger in South Asia of having 'a regime of autocratic rule by the Governor-General dissimilar to that in other parts of the British Commonwealth' ${ }^{865}$ As a clue to South Asian conceptions of the potential powers of the King's Representative, Jinnah himself became Governor-General and not Prime Minister, but nonetheless was the undisputed power in Pakistan. When cajoled by Mountbatten that as Governor-General Jinnah would be restricted and compelled to listen to responsible advice, when he instead he could have more power as Prime Minister, Jinnah replied 'In my position it is I who will give the advice and others will act on it' 866

In India, President Prasad, though not the King's Representative, certainly believed he had more powers than the Constituent Assembly envisaged as the inheritor of the Viceroy's Palace. Rajendra Prasad realised the importance of being the first holder of the Presidency and told the Cabinet that he did not want to be a 'costly non-entity' and with the strength of being elected (indirectly) believed his position was 'different from that of the King' since 'people do look upon him [President of India] also as a person having some authority in the governance of the country' sworn to defend the constitution even in the face of Cabinet opposition as was shown over the Hindu Code Bill where the President believed he was entitled to involve himself in policy details and even reject legislation that was against the 'dictates of my own conscience'. ${ }^{867}$ Nehru, as a Prime Minister can, applied political pressure that convincingly defeated Prasad and in doing so ended the President's power to be an effective source of horizontal accountability on Indian Prime Ministers.

Ceylon's elite ridden polity relied on the Governor-General's political involvement to an inordinate degree. Lord Soulbury, a pillar of the Westminster establishment, still

\footnotetext{
${ }^{865}$ Earl of Listowel [British Secretary of State for India] to Mountbatten, 24 July 1947 in Constitutional Relations Between Indian and Britain - The Transfer of Power 1942-7, Vol. XII, p 328

${ }^{866}$ Viceroy's Personal Report No. 11, 4 July 1947 in Constitutional Relations Between Indian and Britain - Transfer of Power 1942-7, Vol. XI, pp 898-899

${ }^{867}$ Prasad, President's Status vis-à-vis Council of Ministers, 24 January 1951, Dr Rajendra Prasad: Correspondence and Select Documents, Vol. XIV, pp 278-280 and President's Enclosure for Cabinet, 15 September 1951, C. Rajagopalachari Papers, NMML
} 
saw fit to breach the high conventions of his homeland and appoint as Prime Minister a person who did not explicitly carry the confidence of his colleagues or Parliament. By engaging in the personalist transaction of selecting Senanayake the younger to honour his pledge to Senanayake the elder over the claims of Sir John Kotelawala, the leading contender for post, Lord Soulbury 'was violating not only the conventions of Westminster but the laws of Ceylon which supposedly "compelled the GovernorGeneral to act as a constitutional monarch", ${ }^{868}$ The precedent was made and the Ceylonese came to expect such extraordinary actions from the Queen's Representative as was proved when Sir Oliver Goonetilleke took on astonishing powers during the Bandaranaike premiership, when emergency powers were actively exercised by the Governor-General and not the Prime Minister during the communal riots of the late 1950s. ${ }^{869}$ The Ceylonese Governors-General joined with their Prime Ministers in exercising a personalist power partnership rather than functioning as a form of horizontal accountability on Prime Ministers.

In India and Ceylon the Head of State was seen as the "guardian of the Constitution". 870 The long tradition of prime ministerial power had blunted this interpretation for the Governor-General in New Zealand. The Letters Patent 1917 however, and the accompanying Royal Instructions which were in commission till 1983, clearly provided the Governor-General of New Zealand with this responsibility. Though a dormant power, the Governor-General was even empowered to reject the advice of the Cabinet:

In the execution of the powers and authorities vested in him, the GovernorGeneral shall be guided by the advice of the Executive Council, but if any case he shall see sufficient cause to dissent from the opinion of the said Council, he may act in the exercise of his said powers and authorities in opposition to the opinion of the Council... ${ }^{871}$

Sir Cyril Newall, unlike many of his predecessors and successors, believed a GovernorGeneral could use his 'discretionary powers to refuse assent to a course of action

\footnotetext{
${ }^{868}$ Manor, "Setting a Precedent by Breaking a Precedent: Lord Soulbury in Ceylon, 1952”, p 33

${ }^{869}$ Wilson, "The Role of the Governor-General in Ceylon", pp 204-209

${ }^{870}$ The Indian President's oath requires him to 'preserve, protect and defend the Constitution'. Article 60 in Basu, Constitutional Law of India, p 145 and similarly in Ceylon the Governor-General is 'expected to function as the guardian of the Constitution' in Wilson, "The Role of the Governor-General in Ceylon", $p$ 210

${ }^{871}$ Clause V, Instructions Passed Under the Royal Sign Manual and Signet to the Governor-General and Commander-in-Chief of the Dominion of New Zealand, created 11 May 1917
} 
advised by his Ministers' by virtue of being 'the ultimate guardian of the Constitutional Government of the country' even when 'if he thinks that the course of action, while not offending against the letter of the law, is such as to offend against the spirit of fundamental principles of the Constitution'. ${ }^{872}$ Electoral changes surrounding the abolition of the "Country Quota", which had not received the voters sanction, almost threatened the use of Newall's powers, who openly disclosed his constitutional apprehension to the Prime Minister. When changes to the New Zealand political landscape happened during the early 1950s, such as the proclamation of draconian emergency regulations, the "swamping" and subsequent abolition of the Upper House without the promised "alternative", and the early dissolution of a stable Parliament, they did not excite any critical reactions or known concerns from Newall's successor Sir Bernard (soon to be a Lord on Holland's recommendation) Freyberg. Freyberg, the first Governor-General of independent New Zealand established for his successors the political reality that the Governor-General of New Zealand was very much the agent of the Prime Minister and Cabinet, who were seldom diligent in indulging the GovernorGeneral's right to consult, encourage and warn, making the Head of State an ineffective form of horizontal accountability on the Prime Minister and Cabinet.

\section{Prime Minister and Cabinet}

Weller has argued that 'the test of prime ministerial power must be related to capacity and intent'. ${ }^{873}$ In the New Westminsters in their post-independence decade there was not only the 'capacity' and cultural expectation for the use of substantial political executive power through the flexible and adaptable Westminster system, there was also the 'intent' to exercise the full powers available to implement personalist policies and preferences that would shape the executive. The Westminster system endowed an executive that had concentrated centralised power in the Prime Minister and Cabinet substantially derived from its majoritarian control and membership of the legislature. ${ }^{874}$

The post-war era with its uncertainties and nascent constitutional opportunities for these New Westminsters placed considerable political burdens on the executive. As De Smith has argued, the situation for these Commonwealth countries demanded 'strong government, operating in an atmosphere of urgency. A scrupulous devotion to the Queensberry rules or, for that matter, the Westminster rules, may prove a serious

\footnotetext{
${ }^{872}$ Minute by Sir Cyril Newall, 16 March 1946, G48 21 P/6, ANZ

${ }^{873}$ Weller, First Among Equals - Prime Ministers in Westminster Systems, p 17

${ }^{874}$ Lijphart, Patterns of Democracy - Government Forms and Performance in Thirty-Six Countries, p 3
} 
handicap' and so it was. ${ }^{875}$ The Prime Ministers and their Cabinets were faced with unprecedented circumstances. Even New Zealand, though not having as conspicuous a break from Britain as India and Ceylon, had witnessed in this post independent decade the crucial entrenchment of two-party politics with the first ever rotation of power between Labour and National. The leaders of these parties, Fraser and Holland, were amongst the first in New Zealand history to realise and sustain the full powers available to a Prime Minister with a disciplined and cohesive parliamentary party behind them. Both men were able to carry out fundamental constitutional change such as the abolition of the "Country Quota" and Legislative Council with minimal public involvement and deliberation, due to their power as party leaders to easily "command the confidence of the elected house".

Nehru, though idealistically a parliamentary democrat, had an impatience for India that in his mind compelled direct executive action. With the almost anarchic and capricious social forces that clamoured over India, the first Prime Minister saw himself as having an almost divine task to keep India together, which required executive freedom. Nehru dominated economic and foreign policy to propel his vision for India. When his unique concept of "first among was equals" was challenged, Nehru retorted that the Indian Prime Minister 'should have full freedom to act when and how he chooses' as a delegative democracy leader. ${ }^{876}$ Patel, the powerful Deputy Prime Minister responded that such an interpretation was not only not 'in accord with the UK practice' but would 'raise the Prime Minister to the position of a virtual dictator'. ${ }^{877}$ Independent India was always concerned that their new country could be led not by a benevolent and just Rama but a frightening and totalitarian Ravana. ${ }^{878}$

Whatever else, the Congress oligarchy, including Patel, instinctively pushed for 'the strongest and most centralised government achievable in a democracy - the British cabinet system ${ }^{879}$ that endeared the potential for a delegative democracy figure, which they had in Nehru. Pandit Nehru was able to achieve this power only after Patel died in 1950. Patel, the Deputy Prime Minister, had been the strongest and most able form of

\footnotetext{
${ }^{875}$ De Smith, The New Commonwealth and its Constitutions, p 237

${ }^{876}$ Note to Mahatma Gandhi, 6 January 1948, Selected Works of Jawaharlal Nehru, Second Series, Volume 5, p 473

${ }^{877}$ Patel to Nehru and Patel's Note to Mahatma Gandhi, 12 January 1948, in Sardar Patel's Correspondence 1945-50, Vol. VI, p 22

${ }^{878}$ In Indian mythology Rama, an incarnation of Vishnu, was the Hindu model of the ideal man, while Ravana was the demon King of Lanka who captured Rama's wife Sita.

${ }^{879}$ Bernard, "The Presidential Idea in the Constitutions of South Asia", p 49
} 
horizontal accountability on the Prime Minister by virtue of his independence movement credentials, closeness to Gandhi and especially his pervasive influence within the Congress Party. His death robbed Cabinet of its role as an accountability check on the Prime Minister. Cabinet and party, now dominated by Nehru men, meekly delegated their powers to the Prime Minister. Despite his genuine efforts to install key democratic collegial practices, Cabinet declined into the 'weakest' of India's institutions. $^{880}$

Ceylon's cabinet system was more complex. Ceylon's elite typified the naïve hope that they could replicate Westminster cabinet government without any conscious adaptations to their conditions. As discussed above Ceylon, unlike India and New Zealand, lacked a robust party infrastructure that was requisite for the form of Westminster government they wished to copy. Coomaraswamy has analysed that the problem with the Westminster inspired Soulbury Constitution was that 'only a powerful but numerically small elite had been schooled in these customs and conventions. With time the customs would ideologically lose legitimacy and would be the first to be discarded in the Machiavellian exercise of power' since Ceylon was a society 'where patronage is the handmaiden of power [and] commitment to an impartial technocracy becomes politically infeasible' ${ }^{881}$

Such developments occurred due to the inability of Ceylon's elite to adequately generate from the masses a comprehensive institutional and political understanding of the prerequisites for the successful importation of the Westminster system. The major party at the time of independence, the U.N.P., had only been in existence for seventeen months before 1948, showing the lack of political infiltration of parties, which had little in the way of organisation or country-wide integration. ${ }^{882}$ Ceylonese Cabinets were a series of factional alliances of convenience, not a tight disciplined party committee as in most Westminsters. There were no heavyweights like Patel in India, or any collegial operational culture to constrain a Prime Minister's personalism, nor any attempt to promote one, as Nehru had tried in India. Without a true party system, Senanayake and his successors relied for power in Cabinet on feudal kinship ties and fellow members of the elite, as well as fostering politically opportune partnerships with the inhabitant of

\footnotetext{
${ }^{880}$ Gopal, Jawaharlal Nehru - A Biography, Volume Two: 1947-1956, p 303

${ }^{881}$ Coomaraswamy, Sri Lanka - The Crisis of the Anglo-American Constitutional Traditions in a Developing Society, p 12

${ }^{882}$ See Manor, "The Failure of Political Integration in Sri Lanka (Ceylon)", pp 21-41
} 
Queen's House. Despite the trappings of democracy a few elite families and their leader-centric parties dominated the political scene for years to come. ${ }^{883}$ With such executive conditions Ceylon's Westminster was more akin to the factional patronageelite based Westminster of George III than the disciplined party dominated Westminster of George VI.

In New Zealand Fraser, as Prime Minister, bestrode the political scene like a colossus. Not only was this due to his political capabilities and 'iron determination to rule, ${ }^{884}$ but it was also in no small part attributable to the paucity of effective horizontal accountability upon a post-war New Zealand Prime Minister. As a New Westminster, New Zealand was unique in its simplified constitutional structure, which gave 'purity' to the executive. In this small loyalist settler Dominion the executive was not troubled with any formal written constitution, federal or regional government and by 1951 not even a tame upper house. The smallness of the elected House of Representatives allowed for an even more pronounced supremacy of the executive over the legislature than is traditionally expected in Westminsters. Though there was more collegiality at the Cabinet table than in India and especially Ceylon, the New Zealand Cabinet with its tight party basis was dominated by the Prime Minister who had party and political power over them. With the passing of the Statute of Westminster in 1947 ending the nominal deference to the Imperial Parliament, Fraser was now undisputed master in his own land and with his wartime legacy able to dragoon Cabinet, party and Parliament, both politically and constitutionally.

The impressiveness of his political legacy and the uncluttered nature of the New Zealand Westminster enabled his successor to activate the delegated democracy of a New Zealand Prime Minister and take drastic steps to further simplify the constitutional structure. The ease with which Holland's audacious constitutional manoeuvres 'using

\footnotetext{
${ }^{883}$ Janice Jiggins could still write in 1979 that it is notable despite the universal franchise, parliamentary procedures, frequent transference of power at peaceful elections in an increasingly two party system and the emergence of the populist policies of post 1956 - the grip of a few families on place and power in Sri Lanka had been diluted only marginally'. Janice Jiggins, Caste and Family in the Politics of the Sinhalese 1947-1976, Cambridge/Colombo: Cambridge University Press/K. V. G. De Silva \& Sons, 1979, p 96. Inder Malhotra has argued that the Sri Lankans had well established family political dynasties 'a very long time before the Nehru-Gandhis began to be talked of in India as a dynasty' and argues that 'in networking through kinship no country can hold a candle to Sri Lanka'. Malhotra, Dynasties of India and Beyond - Pakistan Sri Lanka Bangladesh, pp 231-237 and 330

${ }^{884}$ Martyn Finlay, "Opening Recollections" in Peter Fraser-Master Politician, p 13
} 
the cutlass rather than the rapier ${ }^{885}$ increased and displayed his power is salutary in understanding the delegative powers available to a Prime Minister without sufficient checks. The active use of emergency regulations during the Waterfront Strike without the calling of parliament; the subsequent snap election without ample constitutional validity; and relative simplicity in ensuring the abolition of a statutory component of Parliament are some examples during this era of personalist prime ministerial power, which detractors of the time labelled 'fascist' and 'oppressive' ${ }^{886}$

New Westminster Prime Ministers were all capable of asserting their primus role in the political system. Whether through prevaricating intrigue or blunt assertion, the Prime Ministers displayed in this era a conscious or subconscious desire to massage and extend the traditional boundaries of prime ministerial influence. However, it must be said the position of Prime Minister has always lacked fixed parameters as an organic creature of convention, especially so in these polities removed from London's historical embrace. Despite India and Ceylon's partial attempts to stipulate and codify the role of Prime Minister the Eastminster Prime Minister's powers evaded definition just as well as their constitutionally unnamed cousin in Wellington. The personalities and relationships on which the Westminster executive is dependent on can never be rigidly legalised, and thus is unwelcome to constitutional tabulation. As Sir Ivor Jennings explained:

It is much easier to draw a formal constitution putting into words the outline of the Westminster model than it is to create the environment and the complex of personal relationships which make the Westminster model work. ${ }^{887}$

The New Westminster executives were faced with circumstances that demanded actions, and their actions obligated them to take a different approach from their historical progenitor at Downing Street. Independence created a time where conventions could be changed by 'deliberate abrogation' or if the Westminster convention was 'felt to be outdated or inconvenient'. Indeed the very nature of conventions means that they 'can

\footnotetext{
${ }^{885}$ F. L. W. Wood, "Sir Sidney George Holland (1893-1961)", rev., Oxford Dictionary of National Biography, Oxford University Press, 2004 [http://www.oxforddnb.com/view/article/33942, accessed 12 July 2007]

${ }^{886}$ Transcript of Trades Union Congress and New Zealand Waterside Workers' Union Deputation to the Prime Minister on 27 February 1951 in Holland Papers, MS 1624-103/6, ATL

${ }^{887}$ Sir Ivor Jennings, Magna Carta and its Influence in the World Today cited in Bradley, "Sir William Ivor Jennings: A Centennial Paper", p 717
} 
develop or extend in new directions by being applied to fresh political circumstances' ${ }^{888}$ The New Westminsters of this era were fertile with the need for new conventions to deal with their unique political and cultural contexts. What was not always realised by the executive at the time was that changes they made would often have long-term effects for better or for worse.

\section{Path Dependency and Critical Juncture Compared}

For Mahoney the 'very definition of path dependence stresses the importance of early events for later occurrences'. ${ }^{889}$ The achievement of full constitutional sovereignty for these New Westminsters in the late 1940s was a 'critical juncture period' that provided 'initial conditions that 'set into motion institutional patterns or event chains that have deterministic properties'. ${ }^{890}$ The gaining of independence in the Eastminster countries of India and Ceylon was for them an obvious cultural and political 'critical juncture period' which gave the local political agents complete decision-making power for the first time. For New Zealand the local ratification of the Statute of Westminster in 1947, just a few months after Indian independence, was less obvious and culturally significant, but nonetheless still a critical juncture period. In path dependent theory 'not only "big" events have big consequences; little ones that happen at the right time can have consequences as well' ${ }^{891}$ The Statute formalised and increased the power of the local executive to have absolute control over their constitutional affairs and was a 'triggering event' that aroused the necessary initial conditions to set off significant political and constitutional change such as the ability to abolish the Upper House. The decisions taken or not taken in this crucial era surrounding the 'critical juncture' in regard to the executive 'even - suboptimal ones - can become self-reinforcing over time' making it difficult to change and 'have major ... consequences' on the political and institutional culture. ${ }^{892}$

It was not possible to examine every event in the first decade of independence that had path dependent outcomes; so the most arguably prominent issue or event was selected to illustrate the path dependence importance of this first era of constitutional autonomy.

\footnotetext{
${ }^{888}$ Geoffrey Marshall, Constitutional Conventions - The Rules and Forms of Political Accountability, Oxford: Clarendon Press Oxford, 1986, p 217

${ }^{889}$ Mahoney, "Path Dependence in Historical Sociology", p 536

${ }^{890}$ Mahoney, "Path Dependence in Historical Sociology", pp 507-508

${ }^{891}$ Pierson, "Increasing Returns, Path Dependence, and the Study of Politics", p 263

${ }^{892}$ Pierson, "The Limits of Design: Explaining Institutional Origins and Change", pp 492-493
} 
The issue or events selected in all three of the New Westminsters were not appreciated at the time as being of critical importance for their nations' future - a common feature in path dependence. This thesis aims to show the importance of the path dependent subjects chosen and justifies them, but cannot, due to space and focuses, examine the future consequences in detail except to outline and intimate their later influence and show its relevance from the post-independent decade.

In India the unique structural and social consequences and circumstances of federalism were analysed. Federalism has been decisive to the endurance of India without any secession and the accompanying accommodation of the vast and varied multitudes than inhabit India. Nehru, in contrast to some of Ceylon's leaders, ignored the temptation of populist politics and the 'expediency of the moment' and instead implored his Chief Ministers in the states to maintain a national 'integrity' and eradicate the 'narrow and parochial outlooks' associated with caste, communalism, religion and language. ${ }^{893}$ The political and social environment in the 1940s and 1950s created the auspices for the distinctive form of federalism that India created. Federalism's origins were critical. The context of needing to incorporate the semi-autonomous Princely States and the vision of Partition, with its harrowing details, encouraged India's political leaders towards federalism.

However, that same context, unprecedented in the Commonwealth at the time, while admitting the need for federalism, also prompted the Constituent Assembly to have a strong and overriding Centre that could, when required, maintain and impose Delhi's dicta on the states. This power of "President's Rule", though envisaged as a last resort, would in fact be abused and later frequently used to inflict the Centre's imprimatur on politically disobedient states. The states were to have, however, extensive powers within their boundaries and through the agitations of many of the components of India's plural communities Nehru, initially reluctant, allowed the process to begin of realigning the states on linguistic and ethnic lines, which was fundamental to maintaining the territorial unity of India. ${ }^{894}$ India's inimitable form of federalism unquestionably prevented the communal strife seen in Ceylon (and later Sri Lanka).

\footnotetext{
${ }^{893}$ Nehru to Chief Ministers, 5 May 1957 in Jawaharlal Nehru, Letters to Chief Ministers 1947-1964, Vol. 4 1954-1957, G. Parthasarathi (ed.), New Delhi: Oxford University Press, 1989, pp 483-485

${ }^{894}$ See Kohli, "Can Democracies Accommodate Ethnic Nationalism? Rise and Decline of SelfDetermination Movements in India”, pp 325-344
} 
For Sri Lanka the issue of communalism is inescapable. In the critical juncture period following independence in 1948 the problems of communalism were no where as prominent or violent as they are today. However, it was still an issue that had a virulent history that obligated its attention in that relatively peaceful era. Indeed, the negotiations for sovereignty with the Colonial Office hinged on the indigenous elite being able to convince the British of being able to 'handle' the situation who argued blithely that 'once the constitutional question is settled, communal questions will cease to be relevant' ${ }^{895}$ However, the platitudes of accommodation for minorities were not followed by necessary institutional and political safeguards that may well have alleviated the ethnic tensions on the island.

The nonchalance and naivety of Ceylon's elite, along with their British friends, effectively ignored the complexity and depth of communalism. By believing that the British Westminster model could institutionally work for Ceylon without significant adaptation, and ignoring the suggestions of structural reform such as federalism or a more representative Senate, they failed in their task of crating a united nation. Ceylon in this critical juncture period and before did not adequately utilise opportunities to institutionally and politically accommodate pluralism - it was a case of opportunity lost. By the end of the period politicians were moving towards sectional populist interests to gain 'short-term horizon' goals that antagonised other groups, which caused a descent into the present quagmire of communal violence.

In 'loyalist' New Zealand the truncation of Parliament was one of earliest actions of the first National Government. The political executive was able to exercise new powers resulting from the constitutional emancipation from the Imperial Westminster with the passing of the Statute of Westminster in 1947. This action not only had institutional consequences for New Zealand's already simplified political structure, it also was a quintessential political exploit that illustrated a lack of institutional checks and balances; it verified the power available to a determined Prime Minister. Holland was able to not only to bypass the wishes of the Upper House, but also those bicameralists in his own Cabinet by shrewd procedural chicanery in busying them in looking for an elusive

\footnotetext{
${ }^{895}$ Letter from Mr Senanayake to Mr Hall, 16 August 1945 in De Silva, British Documents on the End of Empire, Series B - Sri Lanka, Part II, Towards Independence 1945-48, p 39
} 
'alternative' - but only after his personalist objective of abolition had been completed. $^{896}$

Holland knew that by getting abolition first without agreeing to any alternative it would make it next to impossible for any case of bicameral reincarnation. The abolition of the Legislative Council was a demonstrative act that showed the lack of institutional security of many of the components in New Zealand's unwritten system. The Legislative Council's removal was more a convenient casualty in a partisan attack than a sombre and well-argued constitutional reform. It also showed a lack of awareness from both politicians and the public on constitutional matters that was evidenced by the minimal public debate and meaningful parliamentary deliberation on the issue. A delegative democracy Prime Minister was able with minimal difficulty to further simplify New Zealand's Westminster system and advance the erosion of effective horizontal accountability due to the pliancy of the other executive actors. This had the path dependent outcome of having an over powerful and largely unchecked Prime Minister.

For all these three New Westminsters the issues of 1950s are still issues, even if indirectly, today. Though it was not within the scope of this thesis to provide a full picture outside the post-independence decade of these path dependent actions, it is essential to view the broad impact in contemporary times. Of the three cases Sri Lanka's trial with its issue of communalism is the most conspicuous and dangerous. It is interesting to note the recent Vitharana Report to Sri Lanka's All-Party Representative Committee on constitutional reform has, consciously or not, revisited many of the proposals and options available from the 1940s and 1950s. Not only does it advocate a return to a Westminster style parliamentary cabinet government (Sri Lanka has had a Gaullist executive Presidency since 1978), it also seeks to make crucial adaptations for Sri Lanka's circumstances. It argues for greater constitutional safeguards for minorities; the abolition of the executive presidency and return to parliamentary cabinet government; a constitutional court; executive offices like Cabinet should reflect the country's pluralistic nature; a greater sensitivity on language issues and further facilitation of Tamil and Sinhala as equal national languages; the establishment of a Senate to comprise of representatives of the regions and as a check

\footnotetext{
${ }^{896}$ See Cabinet Minutes, 1 March 1950, [CM (50) 9], Cabinet Minutes - Prime Minister's Copies December 1949-June 1950, AAFD 808 1A (49) 1-(50) 39, ANZ
} 
on the lower house; and most importantly it advocates power-sharing and admits the need for practicable devolution to new provinces that address language and ethnic considerations. $^{897}$

The Vitharana Report seemed to be following the Indian Westminster model to deal and accommodate its plural society. Interestingly, a non-Congress Government, perhaps wanting to cut the mire and complexity of India's system, appeared at one stage of political instability in the late 1990 s to want to endanger their federal structure by toying with the idea of following Sri Lanka's Gaullist presidential model, with its unitary powers to more effectively direct the country over the head of Parliament. However, these ideas were never formally activated despite Government calls for a reexamination of the Constitution, which roused fears from the Opposition, judiciary and academia. $^{898}$

As the new millennia arrived the President K. R. Narayanan, a respected former civil servant who began his career in the Nehru era, told Parliament on the fiftieth anniversary of the Republic of India, in a speech not prepared by the Government, that 'our recent experience of instability in government is perhaps not sufficient reason to discard the parliamentary system in favour of the presidential or any other system'. The President, in words that echoed those of Constituent Assembly oligarchs in wanting the flexibility of the Westminster system, stated: 'In my opinion we should avoid too much rigidity in our system of government as in a very rigid system there is the danger of major explosions in society taking place'. ${ }^{899}$ And so the unique Westminster of India endures, not without problems, with its decisive and flexible use of federalism that derived from Britain's colonial rule.

New Zealand's politicians of the era analysed took political actions that often had a 'short term horizon' for populist or partisan means like their Ceylonese counterparts. The abolition of the Legislative Council and the active exhibition of personalist power from a delegative democracy Prime Minister had repercussions for the future. New

\footnotetext{
897 “The Vitharana Report to APRC”, excerpts in The Morning Leader, Vol. 2, No. 28, 10 January 2007, pp 1-9

${ }^{898}$ See Sumit Mitra and Farzand Ahmed, "Review Rift", India Today, International edition, 14 February 2000 and Granville Austin, "Ain’t Broke So Why Fix It”, India Today, International edition, 31 January 2000

${ }^{899}$ President K. R. Narayanan's address on the occasion of the fiftieth anniversary of the Republic of India from the Central Hall of Parliament, 27 January 2000 in Seminar, Issue 487, March 2000, p 9
} 
Zealanders especially by the late 1970 s had begun to question the considerable power delegated to the political executive without sufficient institutional or constitutional checks. Prime Ministers were able to arbitrarily use these powers with minimal institutional scrutiny that could reverse or at least temper their actions. The public were feeling disenfranchised from the political process, which caused the call for renovation to New Zealand's Westminster in the 1990s. The possibility of a Senate was advanced to act as not only a representative body, but also a check on the executive. A reformed Senate may have mitigated, by delaying or amending, the drastic and radical policies of the 1980s and 1990s, which were often not foreshadowed in party manifestos giving an upper chamber justification to intervene in the public interest. ${ }^{900}$

However, New Zealanders wanted greater change, and just as the ghost of the Legislative Council made its reinstallation difficult in the late 1950s, so it would be in the 1990s. Just as it had been radical in ending its bicameral status in the 1950s, New Zealand again made a major deviation from the British Westminster by adopting MMP, a proportional electoral system that not only revolutionised representation, but also ended the two-party system, which had been a crucial source of Fraser and Holland's powers. The once all-powerful executive became 'bridled' though not as tightly as some would wish including current parliamentarians. ${ }^{901}$

The New Westminsters today are still living with the legacy of the critical juncture period that followed independence. This thesis had only scope to examine some aspects of the legacy, but has shown the importance of the post-independence decade as a critical juncture period. The actions and inactions of the executives of the New Westminsters in that period over half a century ago, and their approach to the above issues with their remarkable application of Westminster conventions had deep ramifications. Those New Westminster executives, who had the first taste of full sovereign constitutional power, caused path dependent determinants that have not dulled with time, though this has not always been appreciated.

\footnotetext{
900 This is the convention in Britain see Russell, Reforming the House of Lords - Lessons from Overseas, pp 12-13

${ }^{901}$ See Palmer and Palmer, Bridled Power - New Zealand's Constitution and Government, pp 368-400 and "Inquiry to Review New Zealand's Constitutional Arrangements", Report of the Constitutional Arrangements Committee, I.24A, August 2005, pp 12-27
} 


\section{Conclusion}

The Duke of Windsor, once Emperor of India, exclaimed, during a dinner party in the early 1960s, to Kennedy's soon to be Ambassador to India, J. K. Galbraith:

I hear you are going In-jea...A most interesting country...And you will find the people most agreeable in their own way. They have been uncommonly decent to my niece. ${ }^{902}$

In many ways India had also been 'uncommonly decent' to the political system that the Duke's niece, Elizabeth II, symbolised. India emerging from an often violent struggle to end colonial rule had, without forced imposition, taken on the cabinet parliamentary model central to the system of their former rulers despite the many alternatives, including indigenous ones, available. India, however, like all the New Westminsters, symbolised and operated the Westminster system differently, by design or not, after leaving the constitutional chrysalis at the Palace of Westminster. Though the paternity of their system was seldom in dispute the New Westminsters creatively adapted and mutated their inheritance due to the localised context that was removed from London. Well over a half a century later these countries are still dealing with this inheritance. The changes were not always obvious or intended at the time, and in many cases it is only now that they can be fully appreciated and assessed.

This thesis has examined, using an inter-related three-level theoretical approach, the executives of India, Ceylon and New Zealand as they entered full constitutional independence. The first decade provided a critical juncture period which would have cultural, political and constitutional resonance for latter years. Through a selective analysis of events and issues, and applying theories surrounding cultural conditions, horizontal accountability/delegative democracy and path dependency, this thesis has provided evidence to demonstrate the importance of analysing this era as well as the comparable experience at the executive level of applying the Westminster system to foreign contexts.

The Westminster institutions seemed to be installed with diligence in their new contexts. Erskine May was thumbed, the Speaker's gown was refitted and Sir Ivor

\footnotetext{
902 J. K. Galbraith journal entry, 1 March 1961 in John Kenneth Galbraith, Ambassador's Journal - A Personal Account of the Kennedy Years, Boston: Houghton Mifflin, 1969, p 36
} 
Jennings et al were consulted in person or in pages. And yet the New Westminsters and their institutions and practices did not, and could not function as submissive simulacrums of the original. The main reason for this was that the Westminster system unlike European or American models was based on conventions and flexibility, not rules and rigidity. Bagehot's 'dignified' and 'efficient' conventions and culture were applied in the New Westminsters, though not perhaps as he would have imagined. Westminster's conventions have always allowed if not encouraged deviation, especially so in the New Westminster contexts that demanded 'instant' conventions as the polity had not had the benefit of centuries of evolution. Therein lay the problem and the opportunity for the local executive.

Once complete constitutional sovereignty from Britain was gained in India, New Zealand and Ceylon in the late 1940s and given the Westminster system's predilection for convention and flexibility at the executive, the New Westminsters were delivered the prerogative to generate their own localised executive actions and conventions. These New Westminsters took their responsibilities in different ways. Ceylon sought to imitate British Westminster, since the local elite believed that what worked in Britain would work in Ceylon. Ceylon did an impressive job in mirroring the 'dignified' and ceremonial of British Westminster. The first years of peace and avuncular leadership of D. S. Senanayake even persuaded astute outsiders that that all was well. New Zealand's own premier mandarin, Sir Alister McIntosh, described Ceylon, on a visit there in 1950, as the 'one exception' of a well performing Eastern administration where 'they have taken a grip of the situation' and 'well-trained Native officials appear to be running their show decently and well' ${ }^{903}$ Appearances and the cultural conditions were deceptive in that they did not reveal the tenuous integration of the Westminster system with the masses and Ceylon's plural society or the elites' inability to foster Westminster operational culture at the executive level.

India also had misleading cultural appearances. The republican and nationalist politicians made headlines by ridding India of British Westminster ceremonial symbols such as unceremoniously removing the imposing statutes of British kings and their viceroys from the centre of the capital to a 'macabre and leprous crescent' on the

\footnotetext{
${ }^{903}$ McIntosh to Berendsen, 1 February 1950 in Undiplomatic Dialogue - Letters Between Carl Berendsen \& Alister McIntosh 1943-1952, p 205
} 
outskirts of the city as a lasting and gloomy graveyard to the old Raj. ${ }^{904}$ The Republic of India may have divested itself of many of the symbolic icons of British Westminster, but it retained, through the express wishes of Nehru and the oligarchs, the 'efficient' operational Westminster cabinet system culture that gave flexibility and executive opportunity.

New Zealand alone of the selected New Westminsters culturally refused to acknowledge its independence, due to its vaunted loyalty to Britain, and this formed a mirage that cloaked a very real and active political independence. In fact the executive practices and constitutional usages of Her Majesty's New Zealand advisors were often contrary to those of her British advisors. The belated adoption Statute of Westminster in 1947 did not greatly change New Zealand's powers, but it did confirm and expand the constitutional powers of local executive, which were utilised by abolishing with alacrity and ease an upper house, something even the Queen's British ministers would find difficult, if not constitutionally improbable due to convention.

Various constitutionally dubious actions of the executive actors in these New Westminsters beg the question of the advisability of transplanting or implanting Westminster institutions to such different lands. However, it is not as simple as blaming institutions. With its emphasis on flexibility and the prevalent ambiguity that surrounds the executive's powers, which are devoid of definition and regulation, the Westminster system places undeniable responsibility on the executive actors themselves to mould, operate, symbolise and sometimes ignore or abuse the very institutions and constitutions they were endowed with. As Dr B. R. Ambedkar once candidly admitted, when introducing the draft of India's new constitution with its deliberate Westminster executive features, 'if things go wrong under the new Constitution, the reason will not be that we had a bad Constitution. What we will have to say is that Man is vile'. ${ }^{905}$ The individuals that controlled the great offices of state and institutions associated with them in this period mattered. In this constitutionally and culturally nascent era their impact was often irresistible.

\footnotetext{
904 Jan Morris, Stones of Empire - The Buildings of the Raj, reissued, Oxford: Oxford University Press, 2005, pp 182-185

905 Ambedkar cited in President Narayanan's address on the occasion of the fiftieth anniversary of the Republic of India, 27 January 2000 in Seminar, p 8
} 
In these New Westminsters the local executives were the first ones in the country to be vested with delegative democracy power and endured minimal forms of effective horizontal accountability. Since the awesome potential power offered to the executive was guided by another country's conventions, it created uncertainty and confusion, but also misuse and abuse. Weller has rightly argued that it would be incorrect to argue that the way the British Prime Minister works is the way Prime Ministers should operate' ${ }^{906}$ However, that does not mean, despite the executive flexibility bequeathed from the Westminster system that New Westminster executives should function without restriction or concern.

The massive arbitrary executive power mobilised during the 1947-51 period in New Zealand; the unique and collusive partnerships between the Governor-General and Prime Minister in Ceylon; and the noteworthy interpretation of the Indian Prime Minister's august status with its increasing concentration of power and want of political "freedom" are examples of the dangerous elasticity and flexibility of the conventions that surround a Westminster executive to the cost of parliamentary democracy. Even in the United Kingdom in 2007, Westminster's birthplace, Gordon Brown, just a week after becoming Prime Minister, proposed in a Green Paper to codify or bring under statutory control the Crown's powers as exercised by the Prime Minister and Cabinet to make 'the executive more accountable' and plans 'immediate and specific changes ... that will restrict the power of the Prime Minister and the executive', ${ }^{907}$ perhaps to avoid the dangers of the past.

The Prime Ministers and Cabinets of the New Westminsters exercised substantial power in this era without real controls that had ramifications for their successors. GovernorsGeneral and Presidents were often powerless to resist the political executive and would not or could not effectively activate the latent powers of their positions as the ultimate constitutional guardian. To the Prime Minister, the local Head of State was variously seen as a nuisance, a non-entity or even an accomplice to their political objectives. Cabinet, due either to tight party discipline or being personally beholden to the leader, was not always capable of exerting collegial accountability on their chairman. Horizontal accountability on the Prime Minister from Cabinet or the Head of State

\footnotetext{
${ }^{906}$ Weller, First Among Equals - Prime Ministers in Westminster Systems, p 17

907 The Governance of Britain, presented to Parliament by the Secretary of State for Justice and Lord Chancellor by Command of Her Majesty, CM 7170, London: Her Majesty's Stationary Office, July 2007, pp 7-15
} 
during this period was generally ineffective. The executive actors and Prime Ministers especially, of this period had a deterministic impact, not always beneficial, on the executive customs of their countries. Though their shrines have been neglected, these political idols still deserve, by their deeds and choices, inclusion into the pantheon or pagoda of Westminster deities, though many today would demur from genuflecting before the legacy of these rarefied figures.

As has been established in this thesis, the time analysed in the New Westminsters was a critical juncture period that had path dependent resonance. The wraith of Westminster could not be ignored as a factor during this consequential decade of constitutional independence. The Westminster system was attributable, as a patron at least, to the path dependent outcomes. Though it was not possible to isolate and determine every event, issue and action that had this quality, this thesis identified for each of the three New Westminsters a specific subject that not only affected the political character of the country, but also demonstrated the critical impact, not always appreciated at the time, of the local executive in this era on substantive areas of political importance for future generations.

Ceylon's latent communal tensions were generally hidden during the Colonial period, which encouraged the local elite, through that experience and their anglophile predilections to hail confidence in the British Westminster system as the one to promote a new civic nationalism without any institutional adaptations for their contrasting context. Communalism was thus unable to be tempered by the Westminster way due to the lack of understanding at elite and mass level of the institutional and operational requirements of their country. This neglect of these serious issues placed ethnic relations in jeopardy, which the Sri Lanka is still dealing with. The misguided belief, as well as the inability to properly operate and adapt Westminster in Ceylon when it was possible and the country relatively peaceful had sorrowful consequences for Sri Lanka.

New Zealand's nonchalance over structures and institutions led to the careless abandonment of bicameralism to satisfy the whims of a Prime Minister. Due to New Zealand's executive 'purity' there was negligible political fuss and minimal constitutional difficulties in abolishing the Legislative Council. An unprecedented action in the Commonwealth at the time, the event provided a crass demonstration of 
the political power that can be wielded by a determined Prime Minister as seen especially in Sidney Holland, an example for his successors.

India was compelled by its colossal social conditions to federalism. However, this was not the only reason. The spectre of Partition and the need to integrate the Princely States pushed the need on Nehru and the Constituent Assembly. However, the same reasons and conditions pushed the privileged elite at the Assembly to reincarnate the British Paramountcy for the Republic, which meant a strong centre that could determine and direct the states. Initially hoping that the cleavages of India would evaporate with independence, the Congress Raj soon, and critically, submitted to the need for states to be formed on ethnic and linguistic lines, which did so much to accommodate the country's heaving multitudes and avoid secession or even disintegration.

The constitutional, political and cultural legacy of the Westminster system weighed heavily on the New Westminsters. India, Ceylon and New Zealand for all their rhetoric and remonstrance, both positive and negative, still have Westminster blood in their constitutional veins. The variable viscosity and the difficulty of the transfusions of the 1940s and earlier to these new conditions did not lead to an outright rejection of Westminster nor to its complete immunity from indigenous infections. These New Westminsters evolved and had identifiable characteristics from both its British roots and its local environment. Westminster was not lost; Westminster was regained. 


\section{Appendix}

Governors-General, Presidents and Prime Ministers of India, Ceylon and New Zealand of the Post-Independence Decade

\section{$\underline{\text { India 1947-1957 }}$}

Governors-General (1947-1950)

Admiral of the Fleet Earl Mountbatten of Burma

1947-1948

C. R. Rajagopalachari

1948-1950

Presidents (1950- )

Dr Rajendra Prasad

$1950-1962$

\section{Prime Ministers}

Jawaharlal Nehru

1947-1964

\section{Ceylon 1948-1958}

\section{Governors-General}

Sir Henry Monck-Mason-Moore

1948-1949

Lord Soulbury

1959-1954

Sir Oliver Goonetilleke

1954-1962

\section{Prime Ministers}

Don Stephen Senanayake

1948-1952

Dudley Senanayake

1952-1953

Sir John Kotelawala

1953-1956

S. W. R. D. Bandaranaike

1956-1959

\section{$\underline{\text { New Zealand 1947-1957 }}$}

\section{Governors-General}

Marshall of the Royal Air Force Sir Cyril Newall (pre-indepdence1941-1946) 
Lt. General the Lord Freyberg

1946-1952

Lt. General Sir Willoughby Norrie

1952-1957

Viscount Cobham

1957-1962

Prime Ministers

Peter Fraser

1940-1949

Sidney Holland

1949-1957 


\section{Bibliography}

\section{Unpublished Primary Sources}

Institute of Commonwealth Studies, University of London, London, United Kingdom

- Sir Ivor Jennings Papers, ICS125

D. S. Senanayake's Broadcast, February 4 1948, Ceylon B3

Note by the Prime Minister on Collective Responsibility, c. 1948, Ceylon B3

Jennings to Mr Hingley (Secretary to the Governor-General), 28 March 1952,

Ceylon B3

Lord Soulbury to Jennings, October 5 1953, Ceylon B3

'The Royal Visit to Ceylon, 1954', Ceylon B3

'Five Years of Independent India', c. 1952, India C16

Lord Cobham to Jennings, 2 July 1957 Miscellaneous C17.3

Cobham to Jennings, 25 October 1957, Miscellaneous C17.3

Jennings to Cobham, 2 November 1957, Miscellaneous C17.3

Nehru Memorial Library and Museum, New Delhi, India

- C. Rajagopalachari Papers

Nehru to Rajagopalachari, 30 March 1948

Nehru to Rajagopalachari, 11 April 1948

Minutes of a meeting between His Excellency [Mountbatten] and the Governor-

General Designate [Rajagopalachari], 4 June 1948

Nehru to Purushottam Das Tandon, 8 August 1950

Nehru to Rajagopalachari, 15 September 1951

President's Enclosure for Cabinet, 15 September 1951

- B. N. Rau Papers

Confidential - Memorandum on the Union Constitution, 30 May 1947

Archives New Zealand/Te Whare Tohu Tuhituhinga O Aotearoa, Head Office, Wellington, New Zealand

- Letters and Notes at Government House between October 1942 and October 1943 in $\mathrm{G} 48$ Box $21 \mathrm{P} / 5(3)$ 
- Letter to Governor-General from W.W. Mulholland (Dominion President of NZ Farmers' Union), 1 November 1945, G48 Box 21 P/5(5)

- Telegram from Richard Cobbe to Governor-General, November 2 1945, G48 Box $21 \mathrm{P} / 5(5)$

- Minute by Sir Cyril Newall, 2 November 1945, G48 Box 21 P/5(5)

- Governor-General's Secretary to Mulholland, November 5 1945, G48 Box 21 P/5(5)

- Minute by Newall, 16 March 1946, G48 21 P/6

- Telegram from Newall to King's Private Secretary (Sir Alan Lascelles), 6 November 1945, G48 Box 21 P/5(5)

- Peter Fraser to Mulholland, 7 November 1945, G48 Box 21 P/5(5)

- McIntosh to all NZ Missions overseas re: Statute of Westminster, 19 September 1947, Statute of Westminster 1927-1947, EA 1 159/1/5 Part 4 IA 1 123/6

- G. R. Powles to McIntosh, 30 September 1947, Statute of Westminster 1927-1947, EA 1 159/1/5 Part 4 IA 1 123/6

- Sir Cecil Day, Cabinet Offices, London to McIntosh, 7 October 1947, Statute of Westminster 1927-1947, EA 1 159/1/5 Part 4 IA 1 123/6

- Explanatory notes on Statute of Westminster, Statute of Westminster 1927-1947 File, EA 1 159/1/5 Part 4 IA 1 123/6

- "Summary of Reasons for which New Zealand should adopt the Statute of Westminster", 7 November 1947, Statute of Westminster 1927-1947, EA 1 159/1/5 Part 4 IA 1 123/6

- "Notes on the purpose and effect of the adoption by New Zealand Parliament of Sections 2,3,4,5 and 6 of the Statute of Westminster and the New Zealand Constitutional Amendment (Consent and Request) Bill. Circulated by the Prime Minister and Minister of External Affairs, Rt. Hon. Peter Fraser , 7 November 1947, Statute of Westminster 1927-1947, EA 1 159/1/5 Part 4 IA 1 123/6

- Notes [by an unnamed Civil Servant] on Frederick Doidge's comments, Statute of Westminster 1927-1947, EA 1 159/1/5 Part 4 IA 1 123/6

- Personal Telegram from High Commissioner for New Zealand in London (Sir William Jordan) to Fraser, 2 December 1947, Statute of Westminster 1927-1947, EA 1 159/1/5 Part 4 IA 1 123/6

- Appointment of Governors-General 1947-57, AAFD 811 232A 27/1/4 Part 2

- Note of Meeting, 29 January 1948, Cabinet Papers of the Labour Administration 1948-1949, AAFD 811 1A 1/1/1-1/7/1 
- Cabinet Minutes, 3 September 1948, Cabinet Papers of the Labour Administration 1948-1949, AAFD 811 1A 1/1/1-1/7/1

- Note by Cabinet Secretary, 15 September 1948, Cabinet Records 1948-57, AAFD 811 175G 1/9/1 Part 1

- McIntosh to Sidney Holland - 2 December 1949, AAFD 816/1A 10/1

- Executive Council meeting, 13 December 1949, Change of Government 1949, AAFD 811 W4198/38 48/9/1

- Copies of Letters in The Times, February 1950, between former Liberal leader Lord Samuel (formerly Sir Herbert Samuel) and former wartime Chancellor of the Exchequer Lord Waverly (formerly Sir John Anderson) in AAFD 811 176C 1/12/1

- Cabinet Minutes, 18 January 1950, [CM (50) 1], Cabinet Minutes - Prime Minister's Copies December 1949-June 1950, AAFD 808 1A (49) 1-(50) 39

- Cabinet Minutes, 1 March 1950, [CM (50) 9], Cabinet Minutes - Prime Minister's Copies December 1949-June 1950, AAFD 808 1A (49) 1-(50) 39

- Cabinet Minutes, 16 June 1950, [unnumbered], Cabinet Minutes - Prime Minister's Copies December 1949-June 1950, AAFD 808 1A (49) 1-(50) 39

- Cabinet Minutes, 31 July 1950 [CM (50) 52], Cabinet Minutes - Prime Minister's Copies June - December 1950, AAFD 808 2B (50) 40-88

- Cabinet Minutes, 19 September 1950 [CM (50) 65], Cabinet Minutes - Prime Minister's Copies June - December 1950, AAFD 808 2B (50) 40-88

- Legislative Councillors - Privileges on Vacation of Office - 23 November 1950, (agreed by Cabinet 20 November 1950), IA 1 123/6

- Telegram from the King to Government House, Wellington, 12 December 1950, Biography - Peter Fraser, ABHS 950 W4627 Box 1100 32/8/8 Part 1

- Cabinet Minutes, CM (50) 86, 12 December 1950, Cabinet Minutes - Prime Minister's Copies December 1949-June 1950, AAFD 808 1A (49) 1-(50) 39

- Legislative Councillors, 1950-1951, AAFD 811 16H 42/5/3 Part 1

- Minutes of the Executive Council, 13 January 1954, AAFD 811 W4198/39 48/12/1 File No. 3

- Prime Minister Holyoake to Walter Nash, 11 December 1957, Cabinet Records 1948-57, AAFD 811 175G 1/9/1 Part 1

Alexander Turnbull Library, Wellington, New Zealand

Sir Sidney Holland Papers, MS 1624 
- Undated notes, Legislative Council 1946-49, MS 1624-60/6

- Notes 1946-47 in Opposition Papers 1940-49, Legislative Council 1946-49, MS $1624-60 / 6$

- National Party biography on Rt. Hon. S.G. Holland, P.C., C.H., undated, MS 1624$043 / 5$

- Holland to W. A. Bodkin MP, W. S. Goosman MP, G. H. Mackley MP, T. Clifton Webb MP and R. M. Algie (National Members of the Constitutional Reform Committee), 5 February 1948, Legislative Council 1946-49, MS 1624-60/6

- Transcript of Trades Union Congress and New Zealand Waterside Workers' Union Deputation to the Prime Minister on 27 February 1951, MS 1624-103/6

- Holland to Maj. The Hon. N. A. Rattray, 22 July 1955, Second Chamber 1950-April 1956, MS Papers 1624-093/3

- Holland to Alex McKenzie, 30 April 1956, Second Chamber 1950 - April 1956, MS $1624-93 / 3$

- Sir Mathew Oram to Holland, 1 May 1956, Second Chamber May 1956, MS 1624$93 / 4$

- Holland to McKenzie, 7 May 1956, Holland Papers, Second Chamber 1950 - April 1956, MS 1624-93/3

- Holland to Theo Hills (National Party Secretary), 18 May 1956, Second Chamber May 1956, MS Papers 1624-093/4

- Marshall to Holland, 19 September 1956, Holland Papers, Seconds Chamber, MS $1624-093 / 6$

Sir Alister McIntosh Papers, MS 6759

- Letter from Holland to prospective Councillors, June 1950, contained in A16 Papers Relating to the Abolition of the Legislative Council, MS 6759-051

- Statement by Holland, 20 June 1950, contained in contained in A16 Papers Relating to the Abolition of the Legislative Council, McIntosh Papers, MS 6759-051

- Letter from McIntosh to [now Sir Clifton] Webb in London, 11 June 1957, Personal Correspondence, Hon. Sir Thomas Clifton Webb Papers [within the McIntosh collection], MS Papers 6759-365

Sir John Marshall Papers, MS 1403

- Undated note on Governor-General's powers, MS 1403-069/3 
- National Caucus Meeting, 11 August 1949, Caucus Notes 1947-1949, MS 1403$016 / 5$

- “New Zealand National Party - Policy - General Election 1949”, Campaign Papers 1949, MS 1403-562/3

- National Party paper entitled “The Defeat of the Labour Government 1949”, 14 August 1950, Campaign Papers 1951, MS 1403-563/4

- Menu of State Luncheon, 11 January 1954, MS 1403-069/3

- Prime Minister's Office to Marshall, 30 May 1956, Copied from Cabinet Minutes, 29 May 1956 [CM (56) 25, MS 1403-069/4

\section{Published Primary Sources}

\section{Newspapers specifically used}

The New Zealand Worker, 27 June 1934 (Contained in the Marshall papers)

Evening Post, 7 August 1947

Evening Post, 3 November 1945

Evening Post, 8 November 1945

The Times of India, 25 January 2006

Daily Mirror, 2 March 2007

\section{Official Publications and Documents}

Appendices to the Journals of the House of Representatives, Report of the Constitutional Reform Committee, I-18, 1952

Appendices to the Journals of the Legislative Council, Report of the Select Committee upon the Constitution of the Legislative Council, 1913

British Documents on the End of Empire, Series B - Sri Lanka, Part II, Towards Independence 1945-48, K. M. De Silva (ed.) London: Her Majesty's Stationary Office, 1997

Colonial Office, Ceylon: Report of the Special Commission on the Government of Ceylon, Cmd. 3131, London: His Majesty’s Stationary Office, 1928 
Colonial Office, Ceylon: Report of the Commission on the Constitution, Cmd. 6677, London: His Majesty's Stationary Office, 1945

Constitutional Relations Between Britain and India - The Transfer of Power 1942-7, Volumes I-XII, Nicholas Mansergh, E. W. R. Lumby and Penderel Moon (eds.), London: Her Majesty's Stationary Office, 1970-83

Documents and Speeches on British Commonwealth Affairs 1931-1952, Nicholas Mansergh (ed.), Volume I-II, London: Oxford University Press, 1953

Documents and Speeches on Commonwealth Affairs 1952-1962, Nicholas Mansergh (ed.), London: Oxford University Press, 1963

Independence Day Souvenir, Independent Ceylon - The First Year, issued by the Department of Information, The Government of Ceylon, 1949

"Inquiry to Review New Zealand's Constitutional Arrangements", Report of the Constitutional Arrangements Committee, I.24A, August 2005

Instructions Passed Under the Royal Sign Manual and Signet to the Governor-General and Commander-in-Chief of the Dominion of New Zealand, created 11 May 1917

Letters Patent Relating to the Office of Governor-General, created 11 May 1917 [New Zealand]

New Zealand Foreign Policy - Statements and Documents 1943-1957, Wellington: Government Printer, 1972

New Zealand Parliamentary Debates

Quentin-Baxter, Alison, Review of the Letters Patent 1917 Constituting the Office of Governor-General of New Zealand, Wellington: Cabinet Office, June 1980 
Speeches and Documents on the British Dominions 1918-1931 - From Self-Government to National Sovereignty, Arthur Berriedale Keith (ed.) London: Oxford University Press, 1938

The Constitution of Ceylon, Sir Ivor Jennings (ed.) $3^{\text {rd }}$ edition, Oxford: Oxford University Press, 1953

The Framing of India's Constitution - Select Documents, B. Shiva Rao (ed.), Volumes I-IV, Bombay: The Indian Institute of Public Administration, 1966-68

The Governance of Britain, presented to Parliament by the Secretary of State for Justice and Lord Chancellor by Command of Her Majesty, CM 7170, London: Her Majesty's Stationary Office, July 2007

The New Zealand Constitution Act 1852 (Imp)

The Role of Second Chambers: The Report of a Study Group of the Commonwealth Parliamentary Association, The Parliamentarian - Journal of the Parliaments of the Commonwealth, Vol. LXIII, No. 4, October 1982

“The Vitharana Report to APRC”, excerpts in The Morning Leader, Vol. 2, No. 28, 10 January 2007

\section{Secondary Sources}

Alexandrowicz, C. H., Constitutional Developments in India, Bombay: Oxford University Press, 1957

Algie, R. M., “The Second Chamber in New Zealand", The Parliamentarian - Journal of the Parliaments of the Commonwealth, Vol. XLII, No. 3, July 1961

Alley, Roderic, "The Powers of the Prime Minister" in New Zealand Politics in Perspective, $3^{\text {rd }}$ edition, Hyam Gold (ed.), Auckland: Longman Paul, 1992

Arasaratnam, S., "Nationalism in Sri Lanka and the Tamils", in Sri Lanka-Collective Identities Revisited - Vol. II, ed. Michael Roberts, Colombo: Marga Institute, 1998 
Ashton, S. R., "Ceylon" in The Oxford History of the British Empire: Volume IV - The

Twentieth Century, Judith M. Brown and Wm. Roger Louis, Oxford: Oxford University Press, 2001

Austin, Granville, The Indian Constitution: Cornerstone of a Nation, Oxford: Oxford University Press, 1966

Austin, Granville, Working a Democratic Constitution - The Indian Experience, New Delhi: Oxford University Press, 1999

Austin, Granville, “Ain’t Broke So Why Fix It”, India Today, International edition, 31 January 2000

Bagehot, Walter, The English Constitution - With an Introduction by R. H. S. Crossman, Glasgow: Fontana/Collins, 1978

Barwick, Sir Garfield, Sir John Did His Duty, Wahroonga: Serendip Publications, 1983

Bassett, Michael, Confrontation '51 - The 1951 Waterfront Dispute, Wellington: A. H. \& A. W. Reed, 1972

Bassett, Michael, "The Essentials of Successful Leadership in Twentieth-Century New Zealand Politics", Political Science, Vol. 51, No. 2, December 1999

Bassett, Michael, and King, Michael, Tomorrow Comes the Song - A Life of Peter Fraser, Auckland: Penguin, 2000

Basu, Durga Das, Introduction to the Constitution of India, $18^{\text {th }}$ Edition, New Delhi: Prentice-Hall, 1998

Basu, Durga Das, Constitutional Law of India, $7^{\text {th }}$ edition, New Delhi: Prentice-Hall, 1998 
Beaglehole, J. C., "New Zealand in the Commonwealth: An Attempt at Objectivity" in New Zealand Institute of International Affairs, Contemporary New Zealand - A Survey of Domestic and Foreign Policy, Wellington: New Zealand Institute of International Affairs, 1938

Beaglehole, J. C., "The Statute and Constitutional Change” in J.C. Beaglehole (ed.), New Zealand \& the Statute of Westminster, Wellington: Whitcombe \& Tombs, 1944

Beaglehole, J. C., "The Development of New Zealand Nationality", Journal of World History, Vol. II, No. I, 1954

Beaglehole, J. C., "New Zealand Since the War”, Landfall, Vol. 15, No. 2, June 1961

Belich, James, Paradise Reforged - A History of the New Zealanders From the 1880s to the Year 2000, Auckland: Allen Lane, 2001

Benda, Harry J., "The End of Bicameralism in New Zealand", Parliamentary Affairs, Vol. IV, No. 1, Winter 1950

Benda, Harry J., and Brookes, R. H., "SPQR: A Note on the Proposed Senate", Political Science, Vol. 4, No. 2, September 1952

Bernard, Jean-Alphonse, "The Presidential Idea in the Constitutions of South Asia", Contemporary South Asia, Vol. 1, No. 1, 1992

Bhave, Y. B., The First Prime Minister of India, New Delhi: Northern Book Centre, 1995

Blake, Robert, "Mr Holland - The Energetic Accident”, Here \& Now, No. 1, October 1949

Blundell, Sir Denis, "Some Reflections upon the Office of Governor-General in New Zealand”, Victoria University of Wellington Law Review, Vol. 10, 1980 
Bogdanor, "United Kingdom", in David Butler and D.A. Low (eds.), Sovereigns and Surrogates - Constitutional Heads of State in the Commonwealth, New York: St Martin's Press, 1991

Bogdanor, Vernon, and Marshall, Geoffrey, "Dismissing Governor-Generals" Public Law, 1996

Bogdanor, Vernon, The Monarchy and the Constitution, Oxford: Oxford University Press, 1997

Bongiorno, Frank, "Commonwealthmen and Republicans: Dr H.V. Evatt, the Monarchy and India", Australian Journal of Politics and History, Vol. 46, No. 1, 2000

Bose, Sugata, and Jalal, Ayesha, Modern South Asia - History, Culture, Political Economy, New York: Routledge, 1998

Bose, Sumantra, "Decolonisation and State Building in South Asia", Journal of International Affairs, Vol. 58, No. 1, 2004

Brecher, Michael, Nehru - A Political Biography, Abridged Edition, London: Oxford University Press, 1961

Bradley, A. W., "Sir William Ivor Jennings: A Centennial Paper", Modern Law Review, Vol. 67, No. 5, 2004

Brass, Paul R., The Politics of India since Independence, $2^{\text {nd }}$ edition, Cambridge: Cambridge University Press, 2001

Brooker, Paul, Leadership in Democracy - From Adaptive to Entrepreneurial Initiative, Houndmills: Palgrave Macmillan, 2005

Brookfield, F. M., "No Nodding Automaton: A Study of the Governor-General's Powers and Functions", New Zealand Law Journal, December 1978 
Brookfield, F. M., "The Reconstituted Office of Governor-General”, New Zealand Law Journal, November 1985

Brown, Bruce, "Holyoake's Precursors" in Holyoake's Lieutenants, Margaret Clark (ed.), Palmerston North: Dunmore Press, 2003

Brown, Judith M., and Louis, Wm. Roger (eds.), The Oxford History of the British Empire: Volume IV - The Twentieth Century, Oxford: Oxford University Press, 2001

Brown, Judith M., Nehru - A Political Life, London: Yale University Press, 2003

Brown, Judith, "Jawaharlal Nehru and the British Empire: The Making of an 'Outsider' in Indian Politics", South Asia: Journal of South Asian Studies, Vol. XXIX, No. 1, April 2006

Burroughs, Peter, "Imperial Institutions and the Government of Empire" in The Oxford History of the British Empire: Volume III - The Nineteenth Century, Andrew Porter (ed.), Oxford: Oxford University Press, 1999

Butler, David, and Low, D. A. (eds.), Sovereigns and Surrogates - Constitutional Heads of State in the Commonwealth, New York: St. Martin's Press, 1991

Cannadine, David, Ornamentalism - How the British saw their Empire, London: Penguin, 2002

Cartwright, Dame Silvia, “The Role of the Governor-General”, New Zealand Centre for Public Law, Occasional Paper No. 6, October 2001

Catt, Helena, Harris, Paul, and Roberts, Nigel S., Voter's Choice - Electoral Change in New Zealand?, Palmerston North: The Dunmore Press, 1992

Chakrabarty, Bidyut, "Jawaharlal Nehru and the Administrative Reconstruction in India: A Mere Imitation of the Past or a Creative Initiative?", South Asia: Journal of South Asian Studies, Vol. XXIX, No. 1, April 2006 
Chapman, Robert, "Political Culture: The Purposes of Party and the Current Challenge" in New Zealand Politics in Perspective, $2^{\text {nd }}$ edition, Hyam Gold (ed.), Auckland:

Longman Paul, 1990

Chehabi, H. E., "The Absence of Consociationalism in Sri Lanka”, Plural Societies, Vol. 11, Winter 1980

Clark, Margaret (ed.), Peter Fraser - Master Politician, Palmerston North: Dunmore Press, 1998

Cleveland, L., and Robinson, A. D. (eds.), Readings in New Zealand Government, Wellington: A.H. \& A.W. Reed, 1972

Cobham, Viscount, "The Governor-General's Constitutional Role" in Readings in New Zealand Government, L. Cleveland and A. D. Robinson (eds.), Wellington: A.H. \& A.W. Reed, 1972

Cooke, Sir Robin, “Fundamentals”, New Zealand Law Journal, May 1988

Cooke, Sir Robin, "The Suggested Revolution Against the Crown" in Essays on the Constitution, Philip A. Joseph (ed.), Wellington: Brooker's, 1995

Coomaraswamy, Radhika, Sri Lanka - The Crisis of the Anglo-American Constitutional Traditions in a Developing Society, New Delhi: Vikas, 1984

Coomaraswamy, Radhika, Ideology and the Constitution - Essays on Constitutional Jurisprudence, Delhi: Konrak Publishers, 1997

Cooray, L. J. M., "Operation of Conventions in the Constitutional History of Ceylon, 1948 to 1965”, Modern Ceylon Studies, Vol. 1, No. 1, 1973

Copland, Ian, The Princes of India in the Endgame of Empire, Cambridge: Cambridge University Press, 1997 
Copland, Ian, and Rickard, John (eds.), Federalism - Comparative Perspectives form India and Australia, New Delhi: Manohar, 1999

Copland, Ian, and Rickard, John, "Introduction", in Federalism - Comparative Perspectives form India and Australia, Ian Copland and John Rickard (eds.), New Delhi: Manohar, 1999

Cowen, Sir Zelman, "The Crown and Its Representative in the Commonwealth", Commonwealth Law Bulletin, Vol. 18, January 1992

Cox, Nigel, and Miller, Raymond, "Head of State" in New Zealand Government and Politics, $4^{\text {th }}$ edition, Raymond Miller (ed.), Melbourne: Oxford University Press, 2006

Currie, A. E., New Zealand and the Statute of Westminster 1931, Wellington:

Butterworth \& Co., 1944

Darwin, John, "A Third British Empire? The Dominion Idea in Imperial Politics" in The Oxford History of the British Empire: Volume IV - The Twentieth Century, Judith M. Brown and Wm. Roger Louis (eds.), Oxford: Oxford University Press, 2001

Dasgupta, Jyotirindra, Language Conflict and National Development - Group Politics and National Language Policy, Berkeley: University of California Press, 1970

Dasgupta, Jyotirindra, "India: Democratic Becoming and Developmental Transition" in Politics in Developing Countries - Comparing Experiences with Democracy, $2^{\text {nd }}$ edition, Larry Diamond, Juan J. Linz and Seymour Martin Lipset (eds.), Boulder: Lynne Rienner Publishers, 1995

Dasgupta, Jyotirindra, “India's Federal Design and Multicultural National Construction" in The Success of India's Democracy, Atul Kohli (ed.), Cambridge: Cambridge University Press, 2001

Dell, Edmund, The Chancellors - A History of the Chancellors of the Exchequer 194590, London: Harper Collins, 1996 
De Silva, Chandra R., "Sinhala-Tamil Ethnic Rivalry: The Background”, in Robert B. Goldmann and A. Jeyaratnam Wilson (ed.), From Independence to StatehoodManaging Ethnic Conflict in Five African and Asian States, London: Frances Pinter, 1984

De Silva, K. M., “A Tale of Three Constitutions 1946-8, 1972 and 1978”, The Ceylon Journal of Historical and Social Studies, Vol. VII, No. 2, June-December 1977 (published in 1979)

De Silva, K. M., Managing Ethnic Tensions in Multi-Ethnic Societies: Sri Lanka, 18801985, Washington, D.C.: University Press of America, 1986

De Silva, K. M. and Wriggins, W. Howard., J.R. Jayewardene of Sri Lanka - A Political Biography, Volumes 1-2, London/Honolulu: Anthony Blond/Quartet/University of Hawaii Press, 1988-1994

De Silva, K. M., "Sri Lanka: The Bandaranaikes in the Island's Politics and Public Life - Reflections on the Centenary of S.W.R.D. Bandaranaike's Birth", The Round Table, Vol. 350, 1999

De Silva, K. M., A History of Sri Lanka, (Special Sri Lankan Edition), Colombo: Vijitha Yapa, 2005

De Smith, S. A., "Westminster's Export Models: The Legal Framework of Responsible Government”, Journal of Commonwealth Political Studies, Vol. 1, No. 1, 1961

De Smith, S. A., The New Commonwealth and its Constitutions, London: Stevens \& Sons, 1964

De Vota, Neil, "Control Democracy, Institutional Decay, and the Quest for Eelam: Explaining Ethnic Conflict in Sri Lanka”, Pacific Affairs, Vol. 73, No. 1, Spring 2000

Dharmadasa, K. N. O., Language, Religion, and Ethnic Assertiveness - The Growth of Sinhalese Nationalism in Sri Lanka, Ann Arbor: University of Michigan Press, 1992 
Dion, Stéphane, "Why is Secession Difficult in Well-Established Democracies? Lessons from Quebec”, British Journal of Political Science, Vol. 26, No. 2, April 1996

Dua, Bhagwan, Presidential Rule in India 1950-1984: A Study in Crisis Politics, New Delhi: S. Chand \& Company, 1985

Dua, B. D., "The Prime Minister and the Federal System" in Nehru to the Nineties The Changing Office of Prime Minister in India, James Manor (ed.), New Delhi: Viking, 1994

Eden, Sir Anthony, The Memoirs of the Rt. Hon. Sir Anthony Eden K.G., P.C., M.C. Full Circle, London: Cassell, 1960

Fairburn, A. R. D., "Mr. Fraser's Way of Doing Things", Here \& Now, No. 1, October 1949

Fernando, J. L., Three Prime Ministers of Ceylon - An Inside Story, Colombo: M.D. Gunasena \& Co., 1963

Fieldhouse, D. K., “Autochthonous Elements in the Evolution of Dominion Status: The Case of New Zealand", Journal of Commonwealth Political Studies, Volume 1, 1962

Finlay, Martyn, “Opening Recollections" in Peter Fraser - Master Politician, Margaret Clark (ed.), Palmerston North: Dunmore Press, 1998

Freyberg, Paul, Bernard Freyberg V.C. - Soldier of Two Nations, London: Hodder \& Stoughton, 1991

Galbraith, John Kenneth, Ambassador's Journal - A Personal Account of the Kennedy Years, Boston: Houghton Mifflin, 1969

Gamble, Andrew, “Theories of British Politics”, Political Studies, Vol. 38, No. 3, September 1990

Gandhi, Rajmohan, Rajaji - A Life, New Delhi: Penguin Books India, 1997 
Gangal, S. C., Prime Minister and the Cabinet in India - A Political Study, New Delhi: Navachetna Prakashan, 1972

Gilbert, Martin, Winston S. Churchill, Never Despair, 1945-65, Vol. VIII, London: William Heinemann, 1988

Gledhill, Alan, The Republic of India: The Development of its Laws and Constitution, London: Stevens and Sons, 1951

Gooneratne, Yasmine, Relative Merits - A Personal Memoir of the Bandaranaike Family of Sri Lanka, London: C. Hurst \& Company, 1986

Gopal, Sarvepalli, Jawaharlal Nehru - A Biography, Volumes 1-3, London: Jonathan Cape, 1975-84

Gopal, Sarvepalli, "Nehru and the Commonwealth" in Retreat from Power - Studies in Britain's Foreign Policy of the Twentieth Century, Vol. 2, David Dilks (ed.), London: Macmillan, 1981

Gopal, Sarvepalli, Radhakrishnan - A Biography, New Delhi: Oxford University Press, 1992

Gopal, Sarvepalli, "Churchill and India" in Churchill - A Major New Assessment of His Life in Peace and War, R. Blake and Wm. Roger Louis (eds.) London: Oxford, 1993

Graham, B. D., "The Prime Minister and the Hindu Right" in Nehru to the Nineties The Changing Office of Prime Minister in India, James Manor (ed.), New Delhi: Viking, 1994

Graham, Sir Douglas, "Reflections on the Constitution”, New Zealand Law Review, 1999

Grant, David, "Anti-Conscription, Conscription and the Referendum" in Peter FraserMaster Politician, Margaret Clark (ed.), Palmerston North: Dunmore Press, 1998 
Gustafson, Barry, From the Cradle to the Grave - A Biography of Michael Joseph Savage, Auckland: Reed Methuen, 1986

Gustafson, Barry, The First 50 Years - A History of the National Party, Auckland: Reed Methuen, 1986

Gustafson, Barry, "The Sorcerer and His Apprentice" in Sir Keith Holyoake - Towards a Political Biography, Margaret Clark (ed.), Palmerston North: Dunmore Press, 1997

Gustafson, Barry, His Way - A Biography of Robert Muldoon, Auckland: Auckland University Press, 2000

Gustafson, Barry, "Populist Roots of Political Leadership in New Zealand" in Raymond Miller and Michael Mintrom (eds.), Political Leadership in New Zealand, Auckland: Auckland University Press, 2006

Hailsham, Lord, Elective Dictatorship, The Richard Dimbleby Lecture 1976, London: British Broadcasting Corporation, 1976

Hall, Peter A., and Taylor, Rosemary C. R., "Political Science and the Three New Institutionalisms", Political Studies, Vol. XLIV, 1996

Harrison, Selig, India, The Most Dangerous Decades, Madras: Oxford University Press, 1960

Hart, Henry C., "The Indian Constitution: Political Development and Decay”, Asian Survey, Vol. 20, No. 4, April 1980

Hasluck, Sir Paul, The Office of Governor-General, Melbourne: Melbourne University Press, 1979,

Hasan, Mushirul, “Memories of a Fragmented Nation: Rewriting the Histories of India's Partition" in The Partition in Retrospect, Amrik Singh (ed.), New Delhi: Anamika Publishers, 2000 
Hayward, Margaret, Diary of the Kirk Years, Wellington/Queen Charlotte Sound: Reed/Cape Catley, 1981

Hayward, Margaret, "Prime Minister: Power" in New Zealand Government and Politics, $4^{\text {th }}$ edition, Raymond Miller (ed.), Melbourne: Oxford University Press, 2006

Helms, Ludger, Presidents, Prime Ministers and Chancellors - Executive Leadership in Western Democracy, Houndsmills: Palgrave Macmillan, 2005

Henderson, John, "Prime Minister" in New Zealand Government and Politics, $2^{\text {nd }}$ edition, Raymond Miller (ed.), Auckland: Oxford University Press, 2001

Henderson, Michael, "Setting India's Democratic House in Order: Constitutional Amendments", Asian Survey, Vol. 19, No. 10, October 1979

Hensley, Gerald, Final Approaches - A Memoir, Auckland: Auckland University Press, 2006

Hobbs, Leslie, The Thirty-Year Wonders, Christchurch: Whitcombe and Tombs, 1967

Hobsbawm, Eric, "Introduction: Inventing Traditions", in The Invention of Tradition, Eric Hobsbawm and Terrence Ranger (eds.), Cambridge: Cambridge University Press, 1995

Hodson, H. V., The Great Divide - Britain - India - Pakistan, London: Hutchinson, 1969

Huber, Evelyn, and Stephens, John, Development and Crisis of the Welfare State:

Parties and Policies in Global Markets, Chicago: University of Chicago Press, 2001

Hulugalle, H. A. J., Don Stephen Senanayake - First Prime Minister of Sri Lanka, $2^{\text {nd }}$ edition, Colombo: Arjuna Hulugalle Dictionaries, 2000 
Huntington, Samuel P., Political Order in Changing Societies, New Haven, Conn. : Yale University Press, 1972

Jacob, L. M., Sri Lanka - From Dominion to Republic, Delhi: National Publishing House, 1973

Jackson, W. K. (Keith), The New Zealand Legislative Council-A Study of the Establishment, Failure and Abolition of an Upper House, Dunedin: University of Otago Press, 1972

Jackson, Keith, "Cabinet and the Prime Minister" in Politics in New Zealand - A Reader, Stephen Levine (ed.), Sydney: George Allen \& Unwin, 1978

Jackson, Keith, "The Abolition of the New Zealand Upper House of Parliament” in Two Into One - The Politics and Processes of National Legislative Cameral Change, Lawrence D. Longley and David M. Olson (eds.), Boulder: Westview Press, 1991

Jaffrelot, Christophe, "India and Pakistan: Interpreting the Divergence of Two Political Trajectories”, Cambridge Review of International Affairs, Vol. 15, No. 2, 2002

Jalal, Ayesha, "Inheriting the Raj: Jinnah and the Governor-Generalship Issue", Modern Asian Studies, Vol. 19, No. 1, 1985

Jalal, Ayesha, The Sole Spokesman - Jinnah, the Muslim League and the Demand for Pakistan, Cambridge University Press, 1985

Jalal, Ayesha, "Secularists, Subalterns and the Stigma of Communalism: Partition Historiography Revisited", Modern Asian Studies, Vol. 30, No. 3, July 1996

Jalal, Ayesha, Democracy and Authoritarianism in South Asia - A Comparative and Historical Perspective, Cambridge: Cambridge University Press, 1997

James, Colin (ed.), Building the Constitution, Wellington: Institute of Policy Studies, 2000 
Jayaratne, B. C. F., “Abolition of the Senate of Ceylon”, The Parliamentarian - Journal of the Parliaments of the Commonwealth, Vol. LIII, No. 2, April 1972

Jeffrey, Robin, People, Princes and Paramount Power - Society and Politics in the Indian Princely States, Delhi: Oxford University Press, 1978

Jeffrey, Robin, “The Prime Minister and the Ruling Party" in Nehru to the Nineties The Changing Office of Prime Minister in India, James Manor (ed.), New Delhi: Viking, 1994

Jeffries, Sir Charles, 'O.E.G.’ A Biography of Sir Oliver Ernest Goonetilleke, London: Pall Mall Press, 1969

Jenkins, Roy, Mr Balfour's Poodle - People v. Peers, new edition, London: Papermac, 1999

Jennings, Sir Ivor, The Commonwealth in Asia, London: Oxford University Press, 1951

Jennings, Sir Ivor, Some Characteristics of the Indian Constitution - Being Lectures given in the University of Madras during March 1952 under the Sir Alladi Krishnaswami Aiyer Shashtiabdapoorthi Endowment, Madras: Cambridge University Press, 1953

Jennings, Sir Ivor, "D.S. Senanayake and Independence", The Ceylon Historical Journal, D.S. Senanayake Memorial Number, Vol. V, Nos. 1,2,3 \& 4, July \& October 1955 and January \& April 1956

Jennings, Sir Ivor, "Crown and Commonwealth in Asia", International Affairs, Vol. 32, No. 2, April 1956

Jennings, Sir Ivor, Constitutional Laws of the Commonwealth, London: Oxford University Press, 1957

Jennings, Sir Ivor, Cabinet Government, $3^{\text {rd }}$ edition, Cambridge: Cambridge University Press, 1959 
Jennings, Sir Ivor, British Commonwealth of Nations, $4^{\text {th }}$ edition, London: Hutchinson, 1961

Jennings, Sir Ivor, The Queen's Government, London: Penguin Books, 1962

Jiggins, Janice, Caste and Family in the Politics of the Sinhalese 1947-1976, Cambridge/Colombo: Cambridge University Press/K. V. G. De Silva \& Sons, 1979

Jupp, James, Sri Lanka - Third World Democracy, London: Frank Cass, 1978

Kashyap, Subhash C., Jawaharlal Nehru and the Constitution, New Delhi:

Metropolitan, 1982

Kearney, Robert N., Communalism and language in the politics of Ceylon, Durham, North Carolina: Duke University Press, 1967

Keith, K. J., "Constitutional Change" in Thirteen Facets - Essays to Celebrate the Silver Jubilee of Queen Elizabeth the Second 1952-1977, Ian Wards (ed.), Wellington: Department of Internal Affairs, 1978

Kerr, Sir John, Matters of Judgement - An Autobiography, Melbourne: Macmillan, 1978

Khairi, Saeed R., Jinnah Reinterpreted: The Journey from Indian Nationalism to Muslim Statehood, Karachi: Oxford University Press, 1995

Khan, Hamid, Constitutional and Political History of Pakistan, Karachi: Oxford University Press, 2004

King, Michael, The Penguin History of New Zealand, Auckland: Penguin Books, 2003

Kipling, Rudyard, The Five Nations, $7^{\text {th }}$ edition, London: Methuen and Co., 1910 
Kohli, Atul, "Can Democracies Accommodate Ethnic Nationalism? Rise and Decline of Self-Determination Movements in India”, The Journal of Asian Studies, Vol. 56, No. 2, May 1997

Kohli, Atul (ed.), The Success of India's Democracy, Cambridge: Cambridge University Press, 2001

Kotelawala, Sir John, An Asian Prime Minister's Story, London: George G. Harrap \& Co, 1956

Kumarasingham, Harshan, “The 'New Commonwealth' 1947-49: A New Zealand Perspective on India Joining the Commonwealth", The Round Table, Vol. 95, No. 385, July 2006

Kumarasingham, Harshan, "A Democratic Paradox: The Communalisation of Politics in Ceylon 1911-1948”, Asian Affairs, Vol. 37, No. III, November 2006

Ladley, Andrew, "The Head of State" in New Zealand Politics in Transition, Raymond Miller (ed.), Auckland: Auckland University Press, 1997

Ladley, Andrew, "Who Should be Head of State?" in Building the Constitution, Colin James (ed.), Wellington: Institute of Policy Studies, 2000

Lee, H. P., "Emergency Powers in Australian and Indian Federalism" in Federalism Comparative Perspectives form India and Australia, Ian Copland and John Rickard (eds.), New Delhi: Manohar, 1999

Levine, Stephen, "Parliamentary Democracy in New Zealand", Parliamentary Affairs, Vol. 57, No. 3, 2004

Lijphart, Arend, Democracies - Patterns of Majoritarian and Consensus Government in Twenty-One Countries, New Haven: Yale University Press, 1984 
Lijphart, Arend, "The Demise of the Last Westminster System? Comments on the Report of New Zealand's Royal Commission on the Electoral System”, Electoral Studies, Vol. 6, No. 2, August 1987

Lijphart, Arend, “The Puzzle of Indian Democracy: A Consociational Interpretation”, American Political Science Review, Vol. 90. No. 2, June 1996

Lijphart, Arend, Patterns of Democracy - Government Forms and Performance in Thirty-Six Countries, New Haven: Yale University Press, 1999

Lipson, Leslie, The Politics of Equality, Chicago: University of Chicago Press, 1948

Low, D. A. (ed.), Constitutional Heads and Political Crises - Commonwealth Episodes, 1945-85, London: Macmillan, 1988

Low, D. A., "Introduction: Buckingham Palace and the Westminster Model" in Constitutional Heads and Political Crises - Commonwealth Episodes, 1945-85, D. A. Low (ed.), London: Macmillan, 1988

Ludowyk, E. F. C., The Modern History of Ceylon, London: Weidenfeld and Nicolson, 1966

Lyon, Peter and Manor, James (eds.), Transfer and Transformation: Political Institutions in the New Commonwealth, Cambridge: Leicester University Press, 1983

McCraw, David J., “The Zenith of Realism in New Zealand's Foreign Policy”, Australian Journal of Politics and History, Vol. 48, No. 3, 2002

McGechan, R. O., "Status and Legislative Inability" in J.C. Beaglehole (ed.), New Zealand \& the Statute of Westminster, Wellington: Whitcombe \& Tombs, 1944

McGibbon, Ian (ed.), Undiplomatic Dialogue - Letters Between Carl Berendsen \& Alister McIntosh 1943-1952, Auckland: Auckland University Press, 1993 
McGibbon, Ian (ed.), Unofficial Channels - Letters Between Alister McIntosh and Foss Shanahan, George Laking and Frank Corner 1946-1966, Wellington: Victoria University Press, 1999

McIntosh, Sir Alister, "The Origins of the Department of External Affairs", Sir Alister McIntosh (ed.), New Zealand in World Affairs Volume I 1945-1957, Price Milburn, Wellington, 1977

McIntosh, Sir Alister, (ed.), New Zealand in World Affairs Volume I 1945-1957, Price Milburn, Wellington, 1977

McIntosh, Sir Alister, "Working with Peter Fraser in Wartime" in Peter Fraser Master Politician, Margaret Clark (ed.), Palmerston North: Dunmore Press, 1998

Macintyre, Stuart, A Concise History of Australia, $2^{\text {nd }}$ edition, Cambridge: Cambridge University Press, 2004

McIntyre, W. D., "Peter Fraser's Commonwealth: New Zealand and the Origins of the New Commonwealth in the 1940s" in Sir Alister McIntosh (ed.), New Zealand in World Affairs Volume I 1945-1957, Price Milburn, Wellington, 1977

McIntyre, W. David, Dominion of New Zealand: Statesmen and Status 1907-1945, Wellington: New Zealand Institute of International Affairs, 2007

McKinnon, Malcolm, Independence and Foreign Policy - New Zealand in the World since 1935, Auckland University Press, 1993

McLean, Gavin, "From Cocked Hats to Designer Frocks - The 'Queen in Drag' in Twentieth-Century New Zealand' in Exploring the British World: Identity, Cultural Production, Institutions, Kate Darian-Smith (ed.), Melbourne: RMIT Publishing, 2004

McLean, Gavin, The Governors - New Zealand's Governors and Governors-General, Dunedin: Otago University Press, 2006 
McLeay, Elizabeth, The Cabinet \& Political Power in New Zealand, Auckland: Oxford University Press, 1995

McLeay, Elizabeth, "Cabinet" in New Zealand Government and Politics, $4^{\text {th }}$ edition, Raymond Miller (ed.), Melbourne: Oxford University Press, 2006

McLintock, A. H., and Wood, G. A., The Upper House in Colonial New Zealand, Wellington: New Zealand Government Printer, 1987

Macmillan, Harold, Riding the Storm 1956-1959, London: Macmillan, 1971

Mahajan, Sucheta, Independence and Partition - The Erosion of Colonial Power in India, New Delhi: Sage Publications, 2000

Mahoney, James, "Path Dependence in Historical Sociology" Theory and Society, Vol. 29 No. 4, August 2000

Malhotra, Inder, Dynasties of India and Beyond - Pakistan Sri Lanka Bangladesh, New Delhi: Harper Collins

Mallaby, Sir George, From My Level - Unwritten Minutes, London: Hutchinson, 1965

Manor, James, "The Demise of the Princely Order: A Reassessment" in People, Princes and Paramount Power - Society and Politics in the Indian Princely States, Robin Jeffrey (ed.), Delhi: Oxford University Press, 1978

Manor, James, "The Failure of Political Integration in Sri Lanka (Ceylon)", Journal of Commonwealth and Comparative Politics, Vol. XVII, No. 1, March 1979

Manor, James "Setting a Precedent by Breaking a Precedent: Lord Soulbury in Ceylon, 1952”, in D.A. Low (ed.), Constitutional Heads and Political Crises - Commonwealth Episodes, 1945-85, London: Macmillan, 1988

Manor, James, The Expedient Utopian - Bandaranaike and Ceylon, Cambridge: Cambridge University Press, 1989 
Manor, James, "How and Why Liberal and Representative Politics Emerged in India", Political Studies, Vol. XXXVIII, 1990,

Manor, James (ed.), Nehru to the Nineties - The Changing Office of Prime Minister in India, New Delhi: Viking, 1994

Manor, James "The Prime Minister and President" in Nehru to the Nineties - The Changing Office of Prime Minister in India, James Manor (ed.), New Delhi: Viking, 1994

Manor, James, "Centre-State Relations" in The Success of India's Democracy, Atul Kohli (ed.), Cambridge: Cambridge University Press, 2001

Martin, John E., The House - New Zealand's House of Representatives 1854-2004, Palmerston North: Dunmore Press, 2004

Marshall, Geoffrey, Constitutional Conventions - The Rules and Forms of Political Accountability, Oxford: Clarendon Press Oxford, 1986

Marshall, Sir John, "The Power of Dissolution in New Zealand”, The Parliamentarian, Vol. LVIII, No. 1, January 1977

Marshall, Sir John, "Introduction" in The Reform of Parliament-Papers Presented in Memory of Dr Alan Robinson, Sir John Marshall (ed.), Wellington: New Zealand Institute of Public Administration, 1978

Marshall, Sir John, Memoirs, Volumes 1-2, Auckland: Collins, 1983-1989

Massicotte, Louis, "Legislative Unicameralism: A Global Survey and a Few Case Studies”, The Journal of Legislative Studies, Vol. 7, No. 1, 2001

Menon, V. P., The Story of the Integration of the Indian States, Calcutta: Orient Longmans, 1956 
Metcalf, Barbara D., and Metcalf, Thomas R., A Concise History of India, Cambridge: Cambridge University Press, 2002

Miller, Raymond (ed.), New Zealand Government and Politics, $4^{\text {th }}$ edition, Melbourne: Oxford University Press, 2006

Milne, R. S., Political Parties in New Zealand, Oxford: Oxford University Press, 1966

Mitra, Subrata Kumar, "Introduction” in Subrata Kumar Mitra (ed.), The Post-Colonial State in Asia - Dialectics of Politics and Culture, New York: Harvester Wheatsheaf, 1990

Mitra, Sumit, and Ahmed, Farzand, "Review Rift", India Today, International edition, 14 February 2000

Moore, R. J., Liberalism and Indian Politics 1872-1922, London: Edward Arnold, 1966

Moore, R. J., Escape from Empire - The Attlee Government and the Indian Problem, Oxford: Oxford University Press, 1983

Moore, R. J., Making the New Commonwealth, Oxford: Oxford University Press, 1987

Morris, Jan, Farewell the Trumpets - An Imperial Retreat, London: Faber and Faber, 1998

Morris, Jan, Stones of Empire - The Buildings of the Raj, reissued, Oxford: Oxford University Press, 2005

Morris-Jones, W. H., Parliament In India, London: Longmans, Green and Co, 1957

Morris-Jones, W. H., The Government and Politics of India, $2^{\text {nd }}$ Edition, London:

Hutchinson University Library, 1967 
Morris-Jones, W. H., "Shaping the Post-Imperial State: Nehru's letters to Chief Ministers" in Imperialism, the State and the Third World, Mark Twaddle (ed.), London: British Academic Press, 1992

Mulgan, Richard, "The Elective Dictatorship in New Zealand" in New Zealand Politics in Perspective, $3^{\text {rd }}$ edition, Hyam Gold (ed.), Auckland: Longman Paul, 1992

Munshi, K. M., The President under the Indian Constitution, $2^{\text {nd }}$ edition, Bombay: Bharatiya Vidya Bhavan, 1967

Namasivayam, S., The Legislatures of Ceylon, 1928-1948, London: Faber \& Faber, 1951

Namasivayam, S., Parliamentary Government in Ceylon, 1948-1958, Colombo: K.V.G. De Silva \& Sons, 1959

Narayanan, President K. R., Address on the occasion of the $50^{\text {th }}$ anniversary of the Republic of India from the Central Hall of Parliament, 27 January 2000 in Seminar, Issue 487, March 2000

Nariman, Fali. S., "The Office of the President", Journal of Constitutional and Parliamentary Studies, Vol. XXXVII, No. 1-4, January-December 2002

Nehru, Jawaharlal, An Autobiography, London: John Lane the Bodley Head, 1936

Nehru, Jawaharlal, Selected Works of Jawaharlal Nehru, Second Series, Volumes 1-, S. Gopal (ed.), New Delhi: Jawaharlal Nehru Memorial Fund, 1984-

Nehru, Letters to Chief Ministers 1947-1964, Volumes 1-5, G. Parthasarathi (ed.), New Delhi: Oxford University Press, 1985-89

Nehru, Jawaharlal, The Essential Writings of Jawaharlal Nehru, Volumes 1-2, Sarvepalli Gopal and Uma Iyengar (eds.), New Delhi: Oxford University Press, 2003 
Northey, J. F., “The New Zealand Constitution” in J. F. Northey, The A. G. Davis Essays in Law, London: Butterworths, 1965

O’Donnell, Guillermo, "Horizontal Accountability in New Democracies”, Journal of Democracy, Vol. 9, No. 3, 1998

O'Donnell, Guillermo, Counterpoints - Selected Essays in Authoritarianism and Democratisation, Notre Dame: University of Notre Dame Press, 1999

Oliver, Peter C., The Constitution of Independence - The Development of Constitutional Theory in Australia, Canada, and New Zealand, Oxford: Oxford University Press, 2005

Oliver, W. H., "Sir Sidney Holland”, Comment, Vol. 3, No. 1, Spring 1961

Orren, Karen, and Stephen Skowronek, "Beyond the Iconography of Order: Notes for a 'New Institutionalism"' in The Dynamics of American Politics - Approaches and Interpretations, Lawrence C. Dodd and Calvin Jillson (eds.), Boulder: Westview Press, 1994

Palmer, Geoffrey, Unbridled Power - An Interpretation of New Zealand's Constitution $\&$ Government, $2^{\text {nd }}$ edition, Auckland: Oxford University Press, 1987

Palmer, Geoffrey, New Zealand's Constitution in Crisis - Reforming our Political System, Dunedin: John McIndoe, 1992

Palmer, Geoffrey and Palmer, Matthew, Bridled Power - New Zealand's Constitution and Government, $4^{\text {th }}$ edition, Melbourne: Oxford University Press, 2004

Pandey, Gyanendra, Remembering Partition - Violence, Nationalism and History in India, Cambridge: Cambridge University Press, 2001

Panigrahi, D. N., India's Partition - The Story of Imperialism in Retreat, Oxford: Routledge, 2004 
Parekh, Bhiku, Gandhi's Philosophy: A Critical Examination, Notre Dame: University of Notre Dame Press, 1989

Patapan, Haig, Wanna, John and Weller, Patrick (eds.), Westminster Legacies Democracy and Responsible Government in Asia and the Pacific, Sydney: University of New South Wales, 2005

Patel, Vallabhbhai, Sardar Patel's Correspondence 1945-50, Volumes 1-10, Durga Das (ed.), Ahmedabad: Navajivan Press, 1971-74

Phillips, Jock, Royal Summer - The Visit of Queen Elizabeth II and Prince Philip to New Zealand 1953-54, Wellington: Department of Internal Affairs, 1993

Pierson, Paul, "Increasing Returns, Path Dependence, and the Study of Politics", The American Political Science Review, Vol. 94, No. 2, June 2000

Pierson, Paul, "The Limits of Design: Explaining Institutional Origins and Change", Governance: An International Journal of Policy and Administration, Vol. 13, No. 4, October 2000

Pierson, Paul, Politics in Time - History, Institutions, and Social Analysis, Princeton: Princeton University Press, 2004

Pierson, Paul, “The Study of Policy Development”, Journal of Policy History, Vol. 17, No. 1, 2005

Poguntke, Thomas and Webb, Paul, "The Presidentialization of Politics in Democratic Societies: A Framework for Analysis" in The Presidentialization of Politics - A Comparative Study of Modern Democracies, Thomas Poguntke and Paul Webb (eds.), Oxford: Oxford University Press, 2005

Prasad, Bimal, "Jawaharlal Nehru and Partition" in The Partition in Retrospect, Amrik Singh (ed.), New Delhi: Anamika Publishers, 2000 
Prasad, Rajendra, Dr Rajendra Prasad: Correspondence and Select Documents, Volumes I-XI, Valmiki Choudhary (ed.), New Delhi: Allied Publishers, 1984-1995

Pylee, M. V., Constitutional Government in India, $3^{\text {rd }}$ edition, Bombay: Popular Press, 1977

Quentin-Baxter, R. Q., “The Governor-General's Constitutional Discretions: An Essay Towards a Redefinition", Victoria University of Wellington Law Review, Vol. 10, 1980

Rajashekara, H. M., "The Nature of Indian Federalism: A Critique”, Asian Survey, Vol. 37, No. 3, March 1997

Ramusack, Barbara N., The Indian Princes and their States, Cambridge: Cambridge University Press, 2004

Ratnapala, Suri, "Federalism as a Response to Ethnic Regionalism" in Federalism Comparative Perspectives form India and Australia, Ian Copland and John Rickard (eds.), New Delhi: Manohar, 1999

Rau, B. N., India's Constitution in the Making, Madras: Orient Longmans, 1960

Rees, Sir Frederick, "The Soulbury Commission 1944-45”, The Ceylon Historical Journal, D.S. Senanayake Memorial Number, Vol. V, Nos. 1,2,3 \& 4, July \& October 1955 and January \& April 1956

Rhodes, R.A.W., "Shackling the Leader?: Coherence, Capacity and the Hollow Crown", in Patrick Weller, Herman Bakvis, R.A.W. Rhodes (eds.), The Hollow CrownCountervailing Trends in Core Executives, London: Macmillan, 1997

Rhodes, R.A.W and Weller, Patrick, "Westminster Transplanted and Westminster Implanted: Exploring Political Change" in Haig Patapan, John Wanna and Patrick Weller (eds.), Westminster Legacies - Democracy and Responsible Government in Asia and the Pacific, Sydney: University of New South Wales, 2005 
Richter, William L., and Ramusack, Barbara N., "The Chamber and the Consultation: Changing Forms of Princely Association in India”, The Journal of Asian Studies, Vol. 34, No. 3, May 1975

Richter, William, "Traditional Rulers in Post-Traditional Societies: The Princes of India and Pakistan" in People, Princes and Paramount Power - Society and Politics in the Indian Princely States, Robin Jeffrey (ed.), Delhi: Oxford University Press, 1978

Riddiford, D. J., “A Reformed Second Chamber”, Political Science, Vol. 3, No. 2, September 1951

Roberts, Michael, "Ethnic Conflict in Sri Lanka and Sinhalese Perspectives: Barriers to Accommodation”, Modern Asian Studies, Vol. 12, No. 3, 1978

Roberts, Michael, "Problems of Collective Identity in a Multi-Ethnic Society: Sectional Nationalism vs. Ceylonese Nationalism, 1900-1940”, in Michael Roberts (ed.), Sri Lanka - Collective Identities Revisited, Volume I, Marga Institute: Colombo: 1997

Roberts, Michael (ed.), Sri Lanka-Collective Identities Revisited, Volumes I-II, Colombo: Marga Institute, 1997-98

Ross, Angus, "Reluctant Dominion or Dutiful Daughter? New Zealand and the Commonwealth in the Inter-War Years", Journal of Commonwealth Political Studies, Vol. 10, No. 1, 1972

Ross, Angus, "New Zealand Governors-General In the Inter-War Years" in W. $P$. Morrell: A Tribute, G. A. Wood and P. S. O'Connor (eds.), Dunedin: University of Otago Press, 1973

Roth, Herbert, Trade Unions in New Zealand Past and Present, Wellington: Reed Education, 1973

Roy, A., "The High Politics of India's Partition: The Revisionist Perspective", Modern Asian Studies, Vol. 24, No. 2, 1990 
Rudolph, Lloyd I., and Rudolph, Susane Hoeber, In Pursuit of Lakshmi - The Political Economy of the Indian State, Chicago: University of Chicago Press, 1987

Rudolph, Lloyd I., and Rudolph, Susane Hoeber, "Redoing the Constitutional Design: From an Interventionist to a Regulatory State" in The Success of India's Democracy, Atul Kohli (ed.), Cambridge: Cambridge University Press, 2001

Russell, Meg, Reforming the House of Lords - Lessons from Overseas, Oxford: Oxford University Press, 2000

Samarasinghe, Nina, Colonial Policy, Ethnic Politics and the Minorities in Ceylon 1927-1947, London: Oxford University Press, 1989

Santhanam, K., Union-State Relations in India, London: Asia Publishing House, 1960

Sarkar, Sumit, "Indian Democracy: the Historical Inheritance" in The Success of India's Democracy, Atul Kohli (ed.), Cambridge: Cambridge University Press, 2001

Schumpeter, Joseph Capitalism, Socialism and Democracy, New York: Harper Edition, 1974

Scott, K. J., The New Zealand Constitution, Oxford: Oxford University Press, 1962

Shastri, Amita, "Government Policy and the Ethnic Crisis in Sri Lanka", in Michael E. Brown and Sumit Ganguly (ed.), Government Policies and Ethnic Relations in Asia and the Pacific, Cambridge, Massachusetts: MIT Press, 1997

Shastri, Amita and Wilson, A. Jeyaratnam, (eds.), The Post-Colonial States of South Asia: Democracy, Identity, Development and Security, Richmond: Curzon, 2000

Shiva Rao, B., The Framing of India's Constitution - A Study, Bombay: The Indian Institute of Public Administration, 1968

Sheppard, Simon, “Ranking New Zealand's Prime Ministers”, Political Science, Vol. 50, No. $1,\left(50^{\text {th }}\right.$ anniversary issue $)$, July 1998 
Shroff, Marie, "The Role of the Secretary of the Cabinet - The View from the Beehive", New Zealand Centre for Public Law, Occasional Paper No. 5, July 2001

Srinivasan, Krishnan, The Rise, Decline and Future of the British Commonwealth, Houndmills: Palgrave Macmillan, 2005

Sinclair, Keith, Walter Nash, Auckland: Auckland University Press/Oxford University Press, 1976

Sisson, Richard, "Prime Ministerial Power and the Selection of Ministers in India: Three Decades of Change”, International Political Science Review, Vol. 2, No. 2, 1981

Slight, David J., "Refusal of Assent - A Suicidal Safeguard?", New Zealand Law Journal, May 1987

Som, Reba, "Jawaharlal Nehru and the Hindu Code: A Victory of Symbol over Substance”, Modern Asian Studies, Vol. 28, No. 1, 1994

Steger, M. B., Gandhi's Dilemma: Non-violent Principles and Nationalist Power, New York: St Martin's Press, 2000

Stewart, W. Downie, The Right Honourable Sir Francis H. D. Bell, P.C., G.C.M.G., K.C., His Life and Times, Wellington: Butterworth \& Co., 1937

Stockley, Andrew, "Bicameralism in the New Zealand Context", Victoria University of Wellington Law Review, Vol. 16, 1986

Templeton, Malcolm, "Beginnings" in An Eye an Ear and a Voice, Malcolm Templeton (ed.), Wellington: Ministry of Foreign Affairs and Trade, 1993

Tennent, Sir James Emmerson, Ceylon - An Account of the Island Physical, Historical and Topographical, Vol. II, First Published $1859,6^{\text {th }}$ edition, Colombo: Tisara Press, 1977 
Tizard, Dame Catherine, Crown and Anchor: The Present Role of the GovernorGeneral in New Zealand, Wellington: Friends of the Turnbull Library, 1993

Tummala, Krishna K., “The Indian Union and Emergency Powers”, International Political Science Review, Vol. 17, No. 4, October 1996

Tuteja, K. L., "Hindu Consciousness, the Congress and Partition" in The Partition in Retrospect, Amrik Singh (ed.), New Delhi: Anamika Publishers, 2000

Twaddle, Mark, (ed.), Imperialism, the State and the Third World, London: British Academic Press, 1992

Uyangoda, Jayadeva, Questions of Sri Lanka's Minority Rights, Colombo: International Centre of Ethnic Studies, 2001

Venkateswaran, R. J., Cabinet Government in India, London: George Allen \& Unwin, 1967

Vittachi, Tarzie, Emergency '58 - The Story of the Ceylon Race Riots, London: Andre Deutsch, 1958

Vowles, Jack, and Aimer, Peter, Voters' Vengeance - The 1990 Election in New Zealand and the Fate of the Fourth Labour Government, Auckland: Auckland University Press, 1993

Walker, Ranginui, Ka Whawhai Tonu Matou - Struggle Without End, revised edition, Auckland: Penguin Books, 2004

Wanna, John, “New Zealand's Westminster Trajectory: Archetypal Transplant to Maverick Outlier" in Westminster Legacies - Democracy and Responsible Government in Asia and the Pacific, Haig Patapan, John Wanna, and Patrick Weller (eds.), Sydney: University of New South Wales, 2005

Wards, Ian, "Peter Fraser - Warrior Prime Minister" in Peter Fraser - Master Politician, Margaret Clark (ed.), Palmerston North: Dunmore Press, 1998 
Watkins, Tim, “Get it in Writing”, New Zealand Listener, Vol. 204, No. 3456, August $5-11,2006$

Wavell, Lord, The Viceroy's Journal, Sir Penderel Moon (ed.), London: Oxford University Press, 1973

Webb, Leicester, "Leadership in the Labour Party", Political Science, Vol. 5, No. 2, September 1953

Weerakoon, Bradman, Rendering Unto Caesar, Colombo: Vijitha Yapa, 2004

Weerawardana, I. D. S., Government and Politics in Ceylon, Colombo: Ceylon Economic Research Association, 1951

Weerawardana, I. D. S., The Senate of Ceylon at Work, Colombo: Ceylon University Press, 1955

Weiner, Myron, Party Building in A New Nation - The Indian National Congress, Chicago: University of Chicago Press, 1967

Weiner, Myron, "The Wounded Tiger: Maintaining India's Democratic Institutions" in Transfer and Transformation: Political Institutions in the New Commonwealth, Peter Lyon and James Manor (eds.), Cambridge: Leicester University Press, 1983

Weiner, Myron, The Indian Paradox - Essays in Indian Politics, Ashutosh Varshney (ed.), New Delhi: Sage Publications, 1989

Weller, Patrick, First Among Equals - Prime Ministers in Westminster Systems, Hemel Hempstead: George Allen \& Unwin, 1985

Wheare, Sir Kenneth, Statute of Westminster and Dominion Status, $5^{\text {th }}$ edition, London: Oxford University Press, 1953 
Wheare, Sir Kenneth, Federal Government, $3^{\text {rd }}$ edition, London: Oxford University Press, 1956

Wheare, Sir Kenneth, The Constitutional Structure of the Commonwealth, London: Oxford University Press, 1960

Wickramasinghe, Nira, Sri Lanka in the Modern Age - A History of Contested Identities, London: C. Hurst \& Co, 2006

Wilson, A. Jeyaratnam, “The Governor-General and the State of Emergency, May 1958 - March 1959”, The Ceylon Journal of Historical and Social Studies, Vol. 2, No. 2, July 1959

Wilson, A. Jeyaratnam, “Ceylon Cabinet Ministers 1947-1959 - Their Political, Economic and Social Background", The Ceylon Economist, Vol. 5, No. 1, March 1960

Wilson, A. Jeyaratnam, “The Role of the Governor-General in Ceylon”, Modern Asian Studies, Vol. 2, 1968

Wilson, A. Jeyaratnam, Electoral Politics in an Emergent State: The Ceylon General Election of May 1970, Cambridge: Cambridge University Press, 1975

Wilson, A. Jeyaratnam, S. J. V. Chelvanayakam and the Crisis of Sri Lankan Tamil Nationalism, 1947-1977, London: Hurst \& Company, 1994

Wilson, A. Jeyaratnam, Sri Lankan Tamil Nationalism - Its Origins and Development in the $19^{\text {th }}$ and $20^{\text {th }}$ Centuries, London: Hurst \& Company, 2000

Wilson, Graham, "The Westminster Model in Comparative Perspective”, in Ian Budge and David McKay (eds.), Developing Democracy, London: Sage Publications, 1994

Wilson, Ormond, An Outsider Looks Back - Reflections on Experience, Wellington: Port Nicholson Press, 1982 
Wolpert, Stanley, Nehru - A Tryst of Destiny, New York: Oxford University Press, 1996

Wood, Antony, "New Zealand" in Sovereigns and Surrogates - Constitutional Heads of State in the Commonwealth, David Butler and D. A. Low (eds.) New York: St. Martin's Press, 1991

Wood, G. A., “New Zealand's Single Chamber Parliament: An Argument for an Impotent Upper House?”, Parliamentary Affairs, Vol. 36, No. 3, Summer 1983

Wood, G. A. (ed.), Ministers and Members in the New Zealand Parliament, $2^{\text {nd }}$ edition, Dunedin: University of Otago Press, 1996

Wood, F. L. W., The New Zealand People at War - Political and External Affairs, Wellington: A. H. \& A. W. Reed, 1971

Wood, F. L. W., "Sir Sidney George Holland (1893-1961)”, rev., Oxford Dictionary of National Biography, Oxford University Press, 2004

[http://www.oxforddnb.com/view/article/33942, accessed 12 July 2007]

Woodward, C. A., The Growth of a Party System in Ceylon, Rhode Island: Brown University Press, 1969

Wriggins, W. Howard., Ceylon: Dilemmas of a New Nation, Princeton, New Jersey: Princeton University Press, 1960

Yska, Redmer, All Shook Up - The Flash Bodgie and the Rise of the New Zealand Teenager in the Fifties, Auckland: Penguin, 1993

Ziegler, Philip, Mountbatten - The Official Biography, London: Collins, 1985

Zines, Leslie, Constitutional Change in the Commonwealth, Cambridge: Cambridge University Press, 1991 